SMTHHSONIAN INSTTUUTION LIBRARIES

39088010707040 


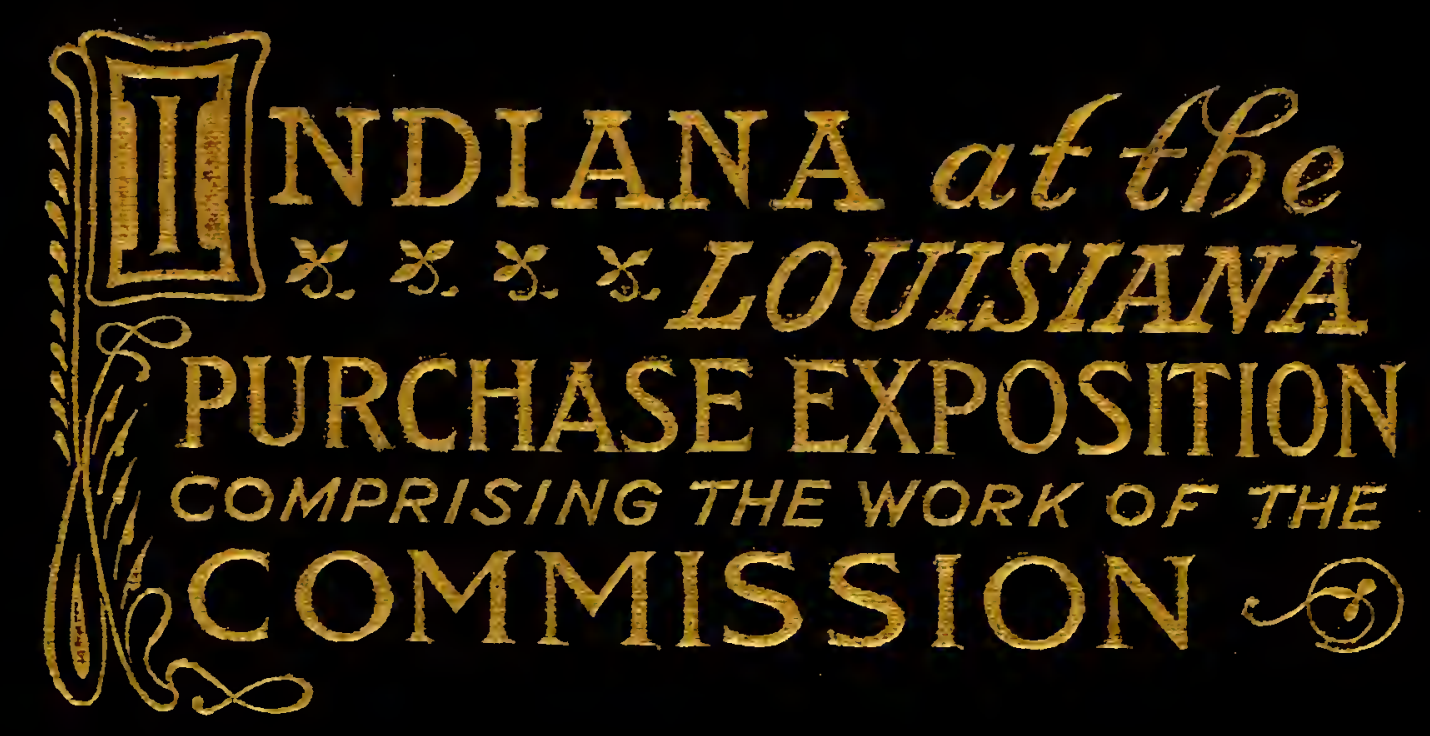






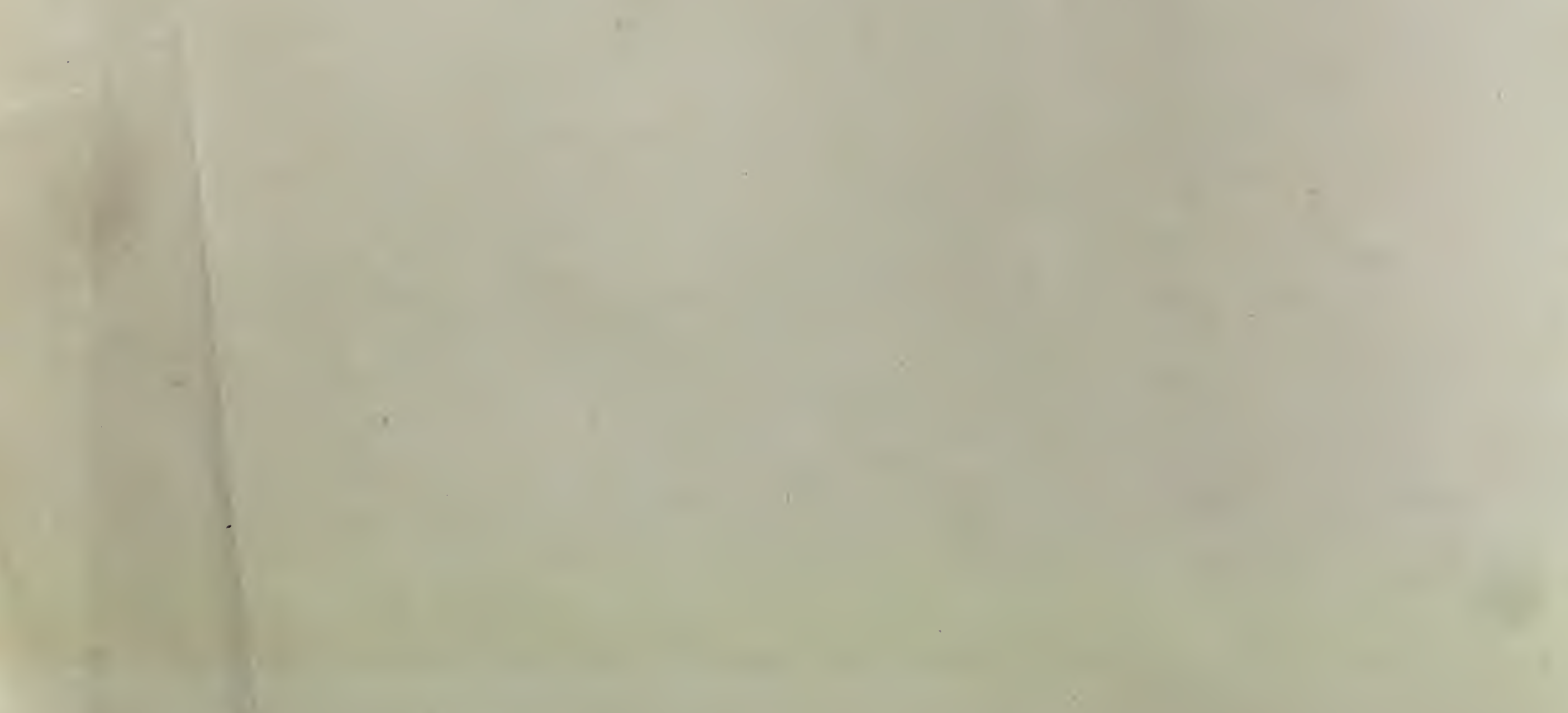




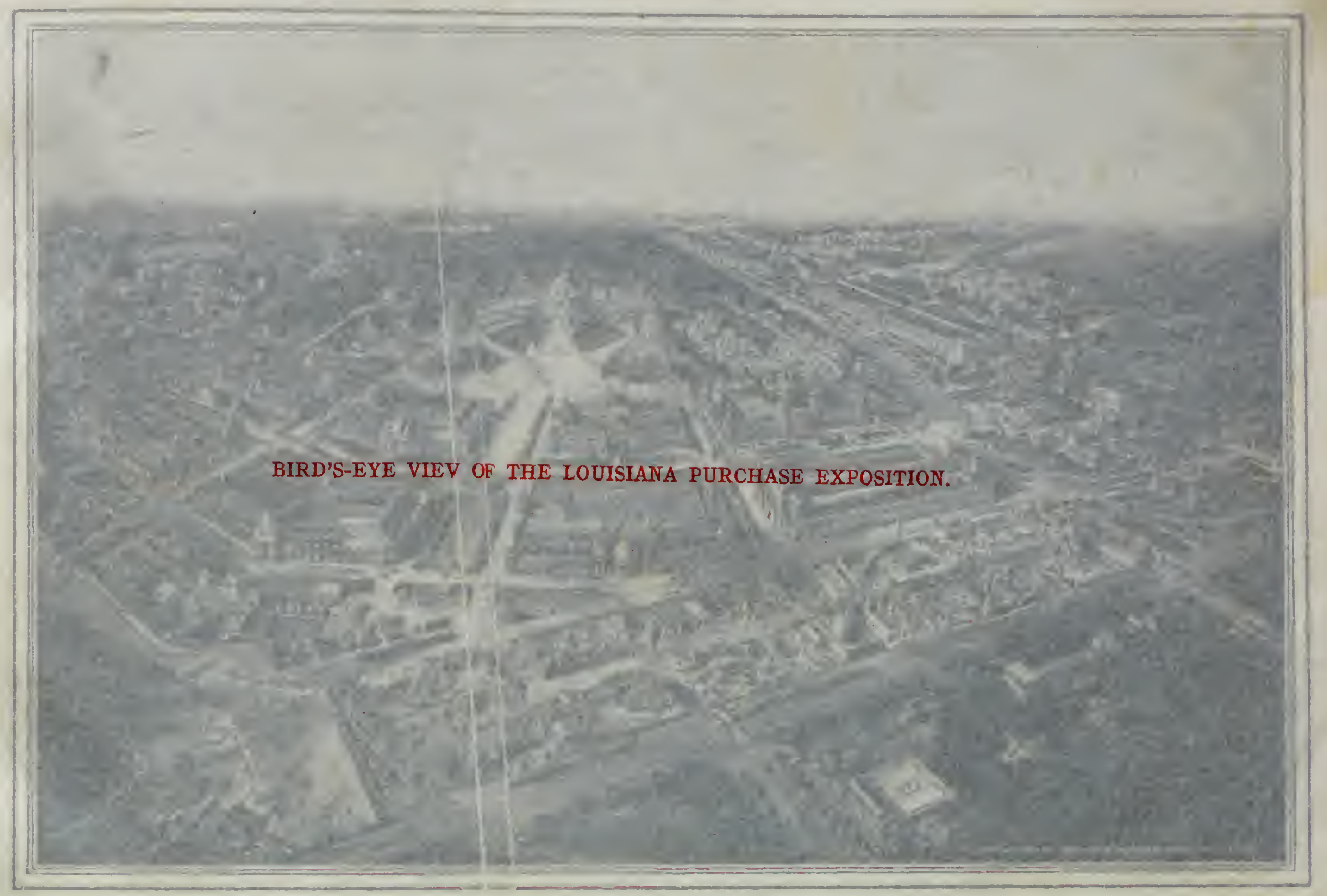




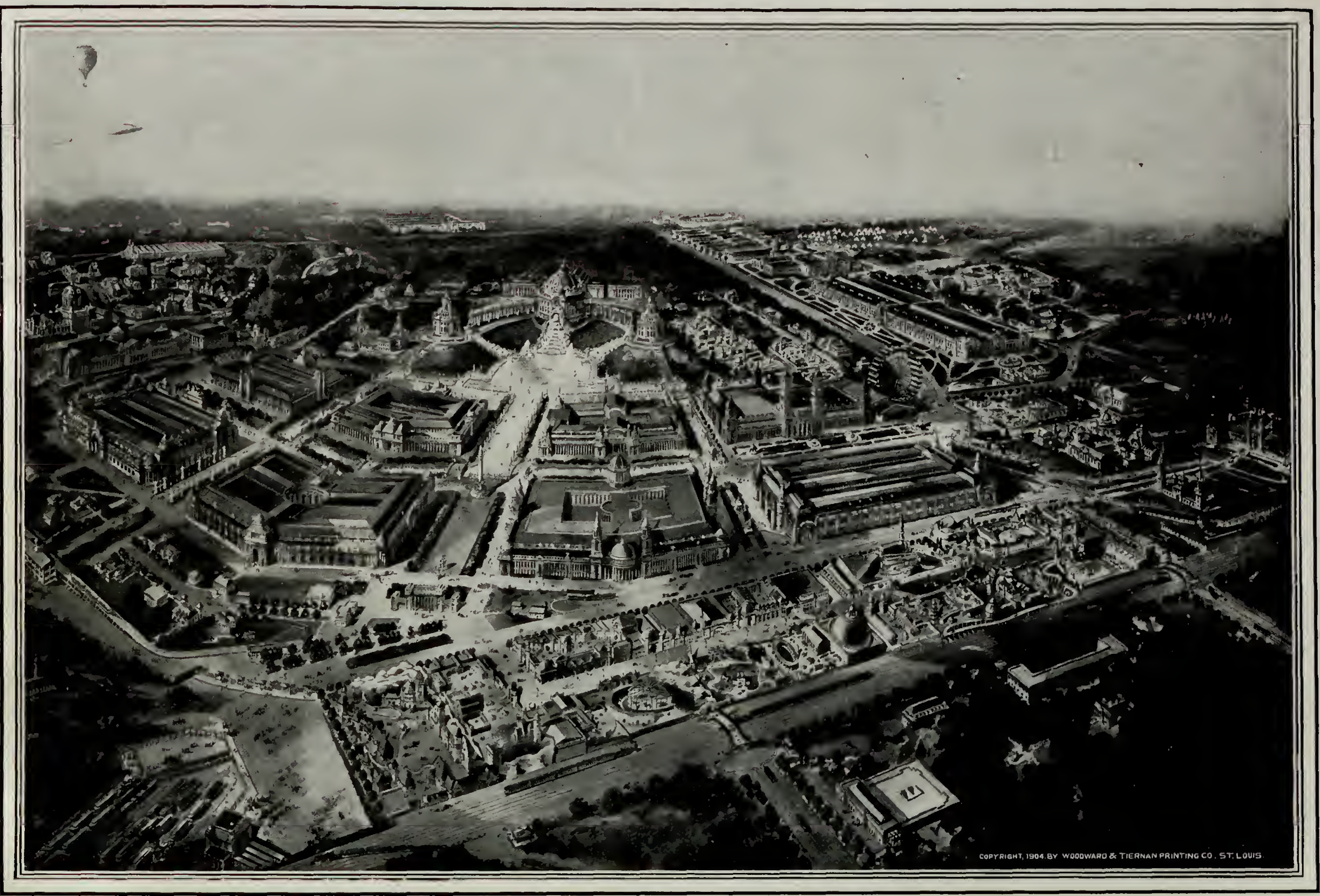




\section{IN DIANA}

\section{AT \\ The Louisiana Purchase Exposition}

COMPRISING THE WORK OF THE COMMISSION, INCLUDING ITS REPORT

PREPARED BY

A. C. ALEXANDER, ASSISTANT SECRETARY. 


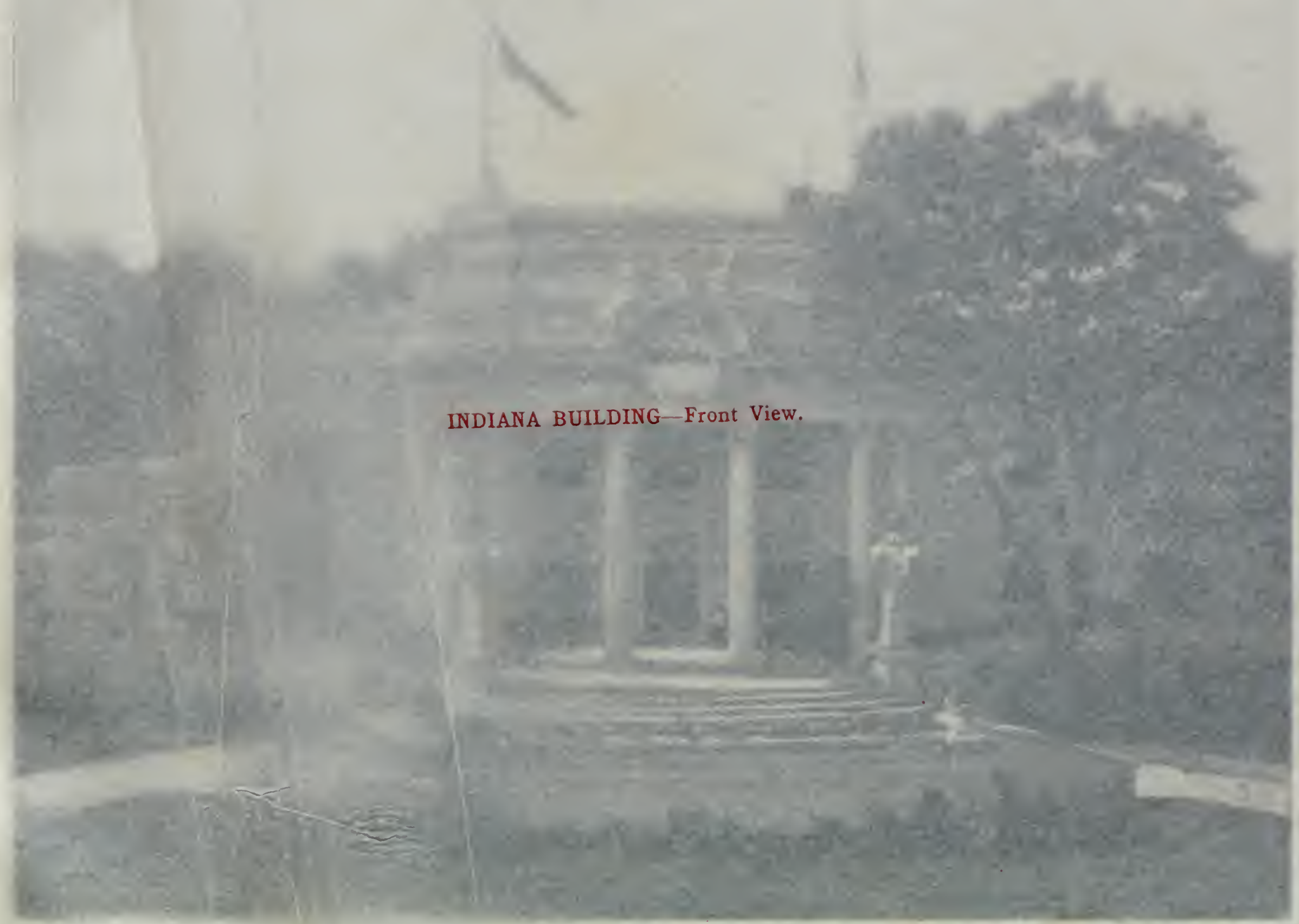




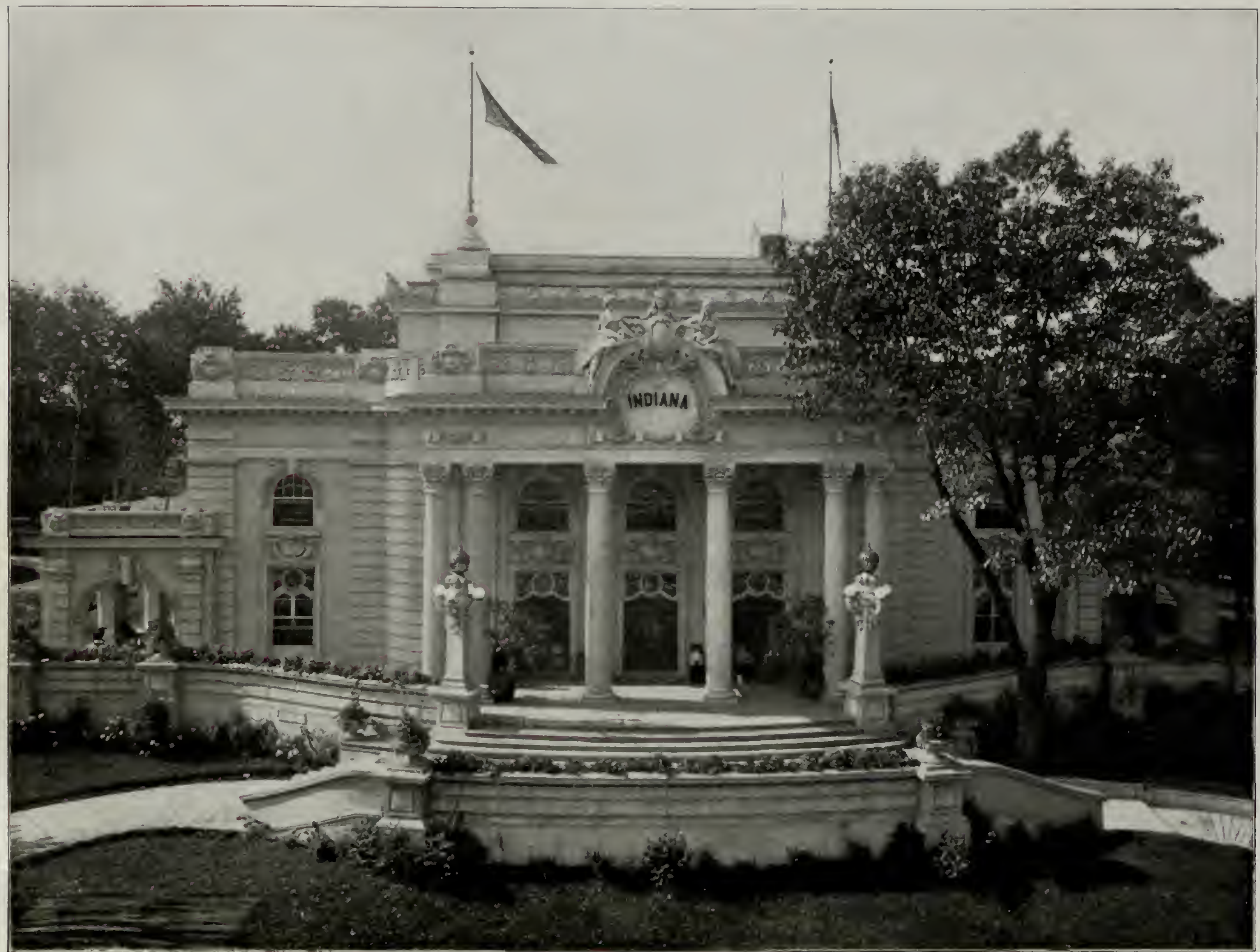




\section{Foreword}

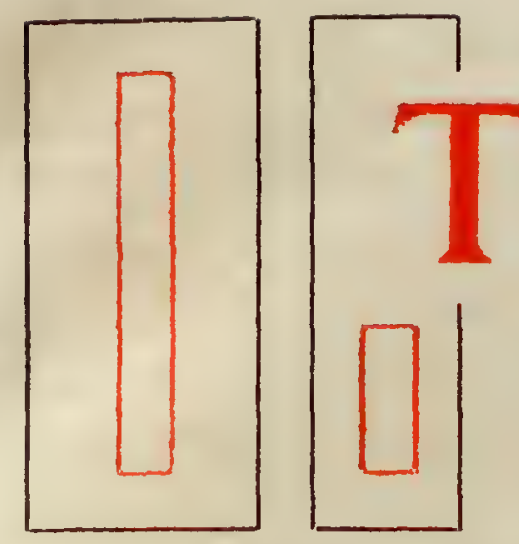

HE Sixty-third General Assembly of the State of Indiana enacted a law providing for the appointment of a "Louisiana Purchase Exposition Commission," to consist of fifteen commissioners, one from each congressional district and two at large, their appointment being vested in the Governor. The act carried an appropriation of $\$ 150,000$ to provide for the expense of erecting a building on the Louisiana Purchase Exposition grounds, and for the preparation and installation of an exhibit of natural resources, commercial advantages, mechanical appliances, educational progress, and other interests and industries of the state of Indiana. The act followed a long period of agitation and investigation relative to the proposed exposition at St. Louis and met with general approval throughout the state. It provided that the members of the Indiana Commission should serve without compensation, and the Governor was left free to select gentlemen who would undertake the work as a patriotic service. The Commission chosen by Governor Durbin was eminently representative in character, comprising in its membership a number of the leading business and professional men of the State. Nearly every one of the varied occupations, industries and callings within thestate, contributed to the work of this Commission some of its most intelligent and enterprising representatives. From the beginning the members of the Commission manifested a disposition to give to the work of providing adequate representation for Indiana at St. Louis the same careful attention, which, applied to their own private affairs had won individual success in their several fields of endeavor. The deliberations of the Commission were characterized from the beginning by thorough harmony in counsel and unity of action.

The result speaks for itself. While the members of the Commission agreed in the opinion that too large a portion of the appropriation should not be expended for the purpose of erecting a state building, yet so carefully and judiciously did they plan the expenditures of the sum determined upon, and so faithfully was the work of construction and equipment supervised, that Indiana did not suffer in comparison with commonwealths which devoted much larger appropriations for this purpose. Above all, the building was typical of the state, of the homely hospitality that has always been characteristic of the Hoosier, and, at the same time, of the distinction which in later years has been achieved by the state in the realms of art and literature. The building was essentially democratic in its construction and in its atmosphere, and while other states may have surpassed Indiana in lavish scale of formal enter- 
tainment, no state building opened its doors more hospitably to a larger number of every-day visitors, or seemed to give more quiet enjoyment to those who sought its shelter.

Eleven general exhibits were installed and maintained in the various palaces of the Exposition devoted to this purpose, divided as follows: Building stone; coal; public schools and libraries; colleges; social economy, comprising exhibits of the State Board of Charities, State Board of Health, Department of factory inspection and the Indiana School for Feeble-Minded Youth; needle and lace work; decorated china; horticulture; dairy; agriculture; and a special exhibit of corn Of these exhibits it may briefly be said that all of them ranked with the best, and no state secured more favorable consideration at the hands of the juries of awards. These exhibits demonstrated not only the present proud position of Indiana in every field of achievement among the commonwealths of the Nation, but particularly the unexampled progress of the state during the last decade.

The work of the Commission did not cease with the construction and care of the Indiana building, or with the installation of state exhibits in the various general buildings. For months prior to the opening of the Exposition the work of arousing popular interest in the approaching fair was carried on in an organized way through the newspapers of the state, and by correspondence with manufacturers and stock raisers, calculated to create sentiment in favor of entering competitive exhibits. The result was noticeable in an attendance from Indiana surpassing that of any state other than Missouri and a long and notable list of prizes won by individuals, firms and corporations. It may well be doubted if any state has secured such generous returns for the time and money expended. Millions of visitors to the greatest fair in history, assembled from all parts of the civilized world, there received an impression of Indiana, her resources and her achievements, which is of incalculable value to the fair fame of our state.

In this little book we have sought to outline briefly the personnel and the work of the Commission, in the belief that the people of Indiana will be interested in knowing something of the details of an undertaking which for years to come will continue to confer inestimable benefit upon the three millions of intelligent and enterprising people who live within the limits of the Hoosier commonwealth. 


\section{Biographical}




\section{Winfield T. Durbin}

Colonel Winfield T. Durbin is a native Indianian, born in Lawrenceburg, May 4, 1847, the son of William S. Durbin, a tanner. The common schools of Washington county gave him his education until the outbreak of the civil war, when he enlisted in the 16th Volunteer Infantry. The military authorities refused to muster him on account of an injury to his arm sustained shortly after entering service, but after the injury had healed, he re-enlisted in the 139th Indiana and served throughout the war as a member of Company A of that regiment.

He taught for a time in the schools of Washington and Johnson counties, then took a course in a commercial college at St. Louis, after which he accepted a position in the wholesale dry goods house of Murphy, Johnson \& Co., of Indianapolis. He entered the employ of this concern as a bookkeeper and became confidential credit man. He removed to Anderson in 1879 and has ever since been engaged in banking and manufacturing.

He has been known as an ardent and active Republican since his youth. In 1892 he went to the National Republican convention as a delegate, having prior to that time served as a member of the Republican State Committee. In 1896 he was made a member of the national committee from Indiana and served on the executive committee, having charge of the western headquarters of his party at Chicago, and since that time has taken a prominent part in the national affairs of the Grand Army of the Republic.

When it was known that Indiana could furnish an additional regiment in the Spanish-American war, Mr. Durbin was appointed Colonel of the 161st Regiment by Governor Mount, and won an enviable reputation as an able commander of troops. He and his regiment went to Cuba for garrison duty.

Governor Durbin was married in 1875 to Miss Bertha McCullough and has one son, Fletcher M. Durbin, who was a Lieutenant of Volunteers in Col. Durbin's regiment during the Spanish-American war.

Mr. Durbin was elected Governor in 1900, his term expiring January 9, 1905. 


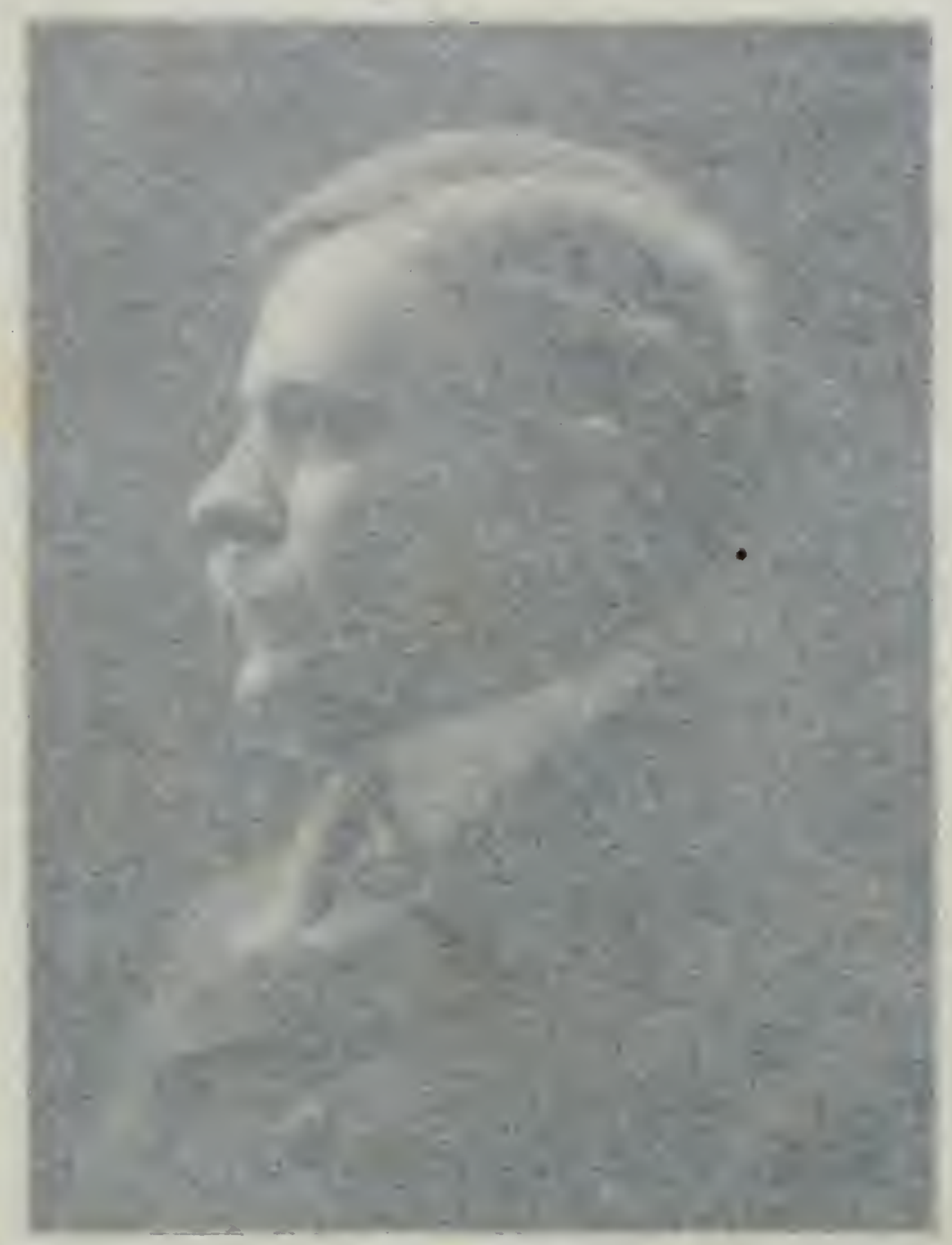

GOVERNOR WINFIELD T. DURBIN. 


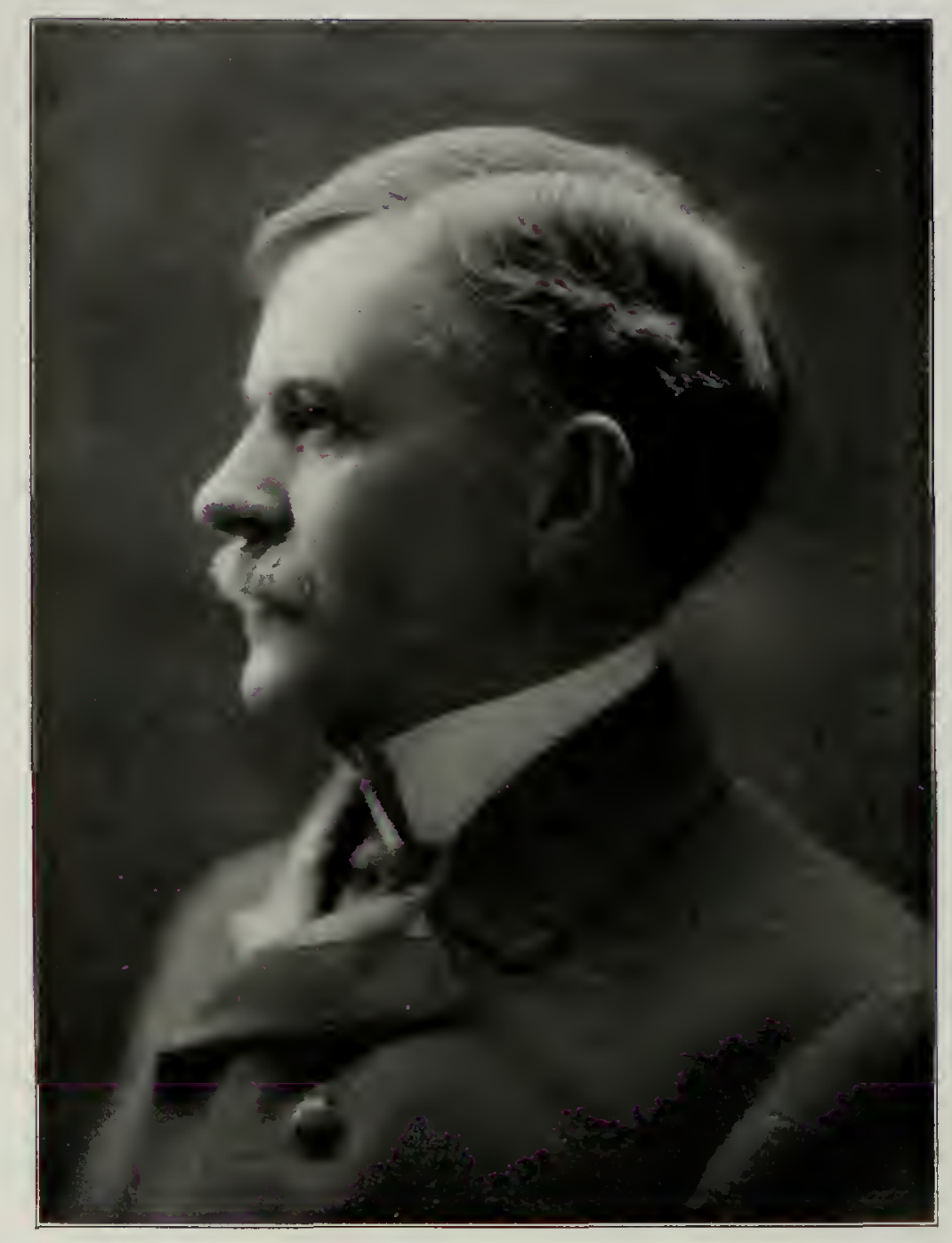




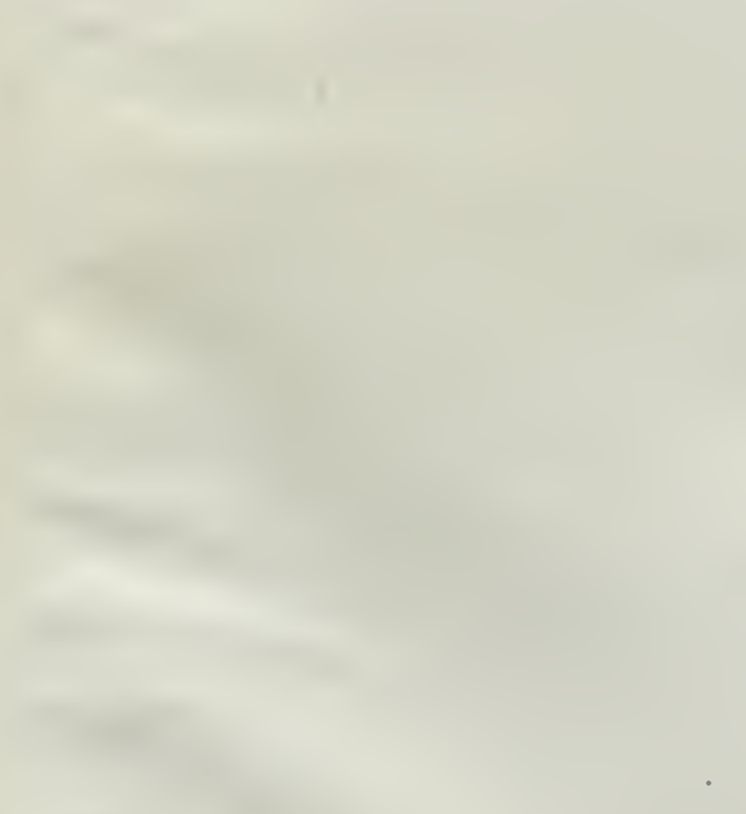




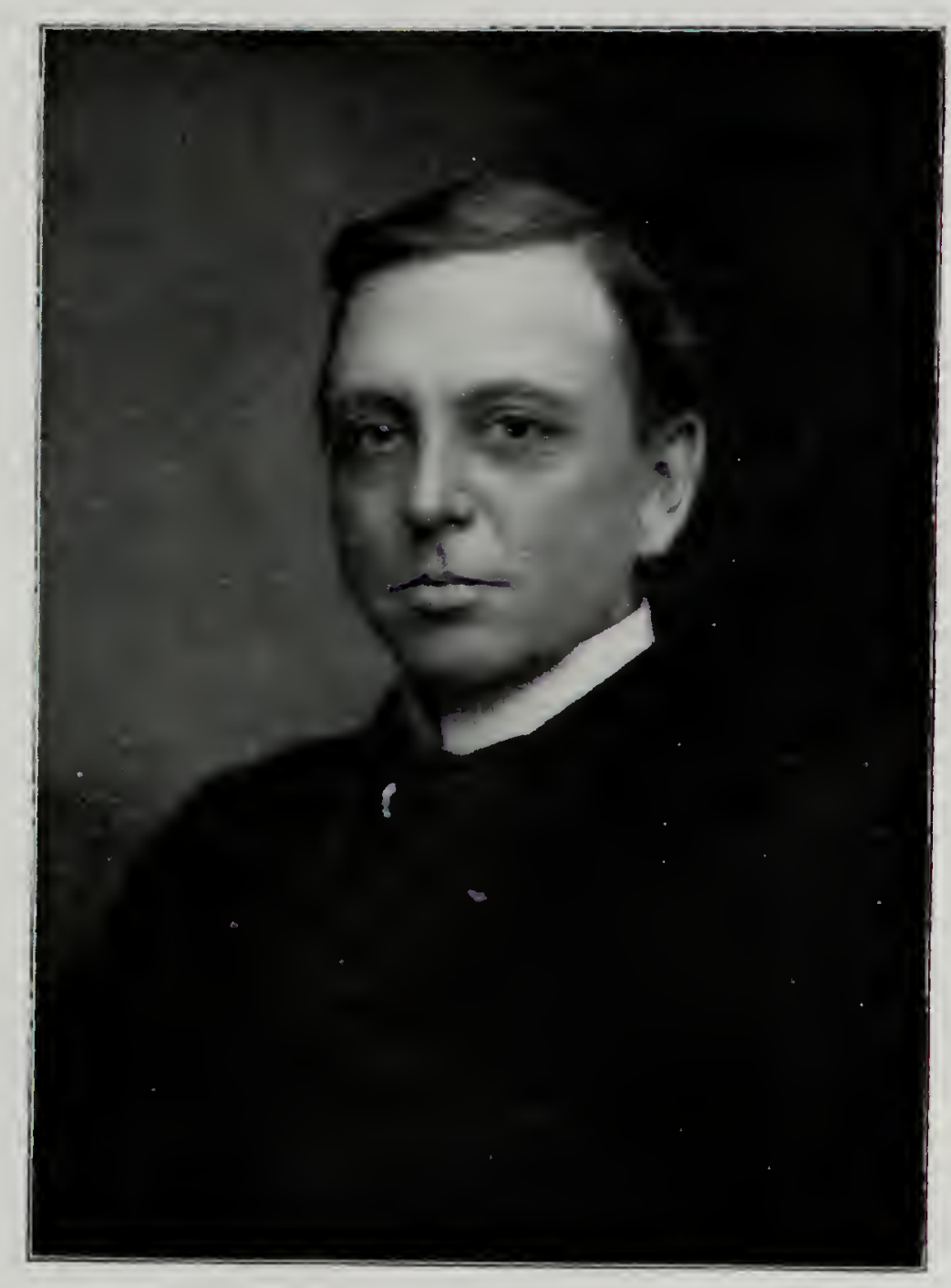




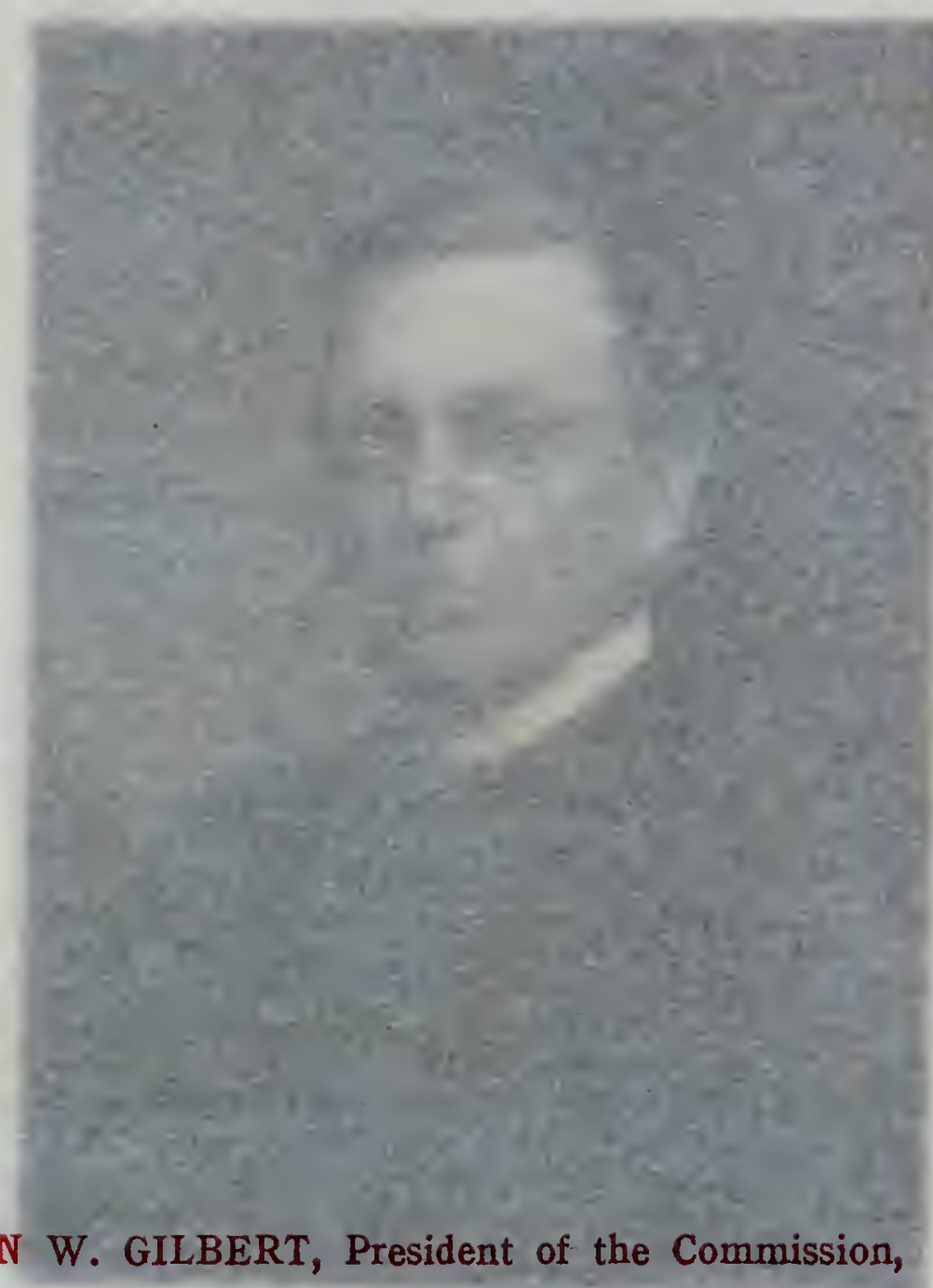

NEWTON W. GILBERT, President of the Commission,

Commissioner at Large. 


\section{Newton W. Gilbert}

Newton W. Gilbert was born in Worthington, Ohio, May 24, 1862. He received his education in the public schools and in the Ohio State University. In 1876 his parents located at Angola, Steuben County, Indiana. Ten years later he was elected Surveyor of his county, serving in that capacity for a number of years. In 1898 he was elected President of the state organization of the Lincoln League, and was reelected in 1899 . In 1896 he was elected to the State Senate and represented Steuben and Lagrange counties in the Sixtieth and Sixty-first General Assemblies.

Mr. Gilbert volunteered his services at the outbreak of the Spanish-American war, and was appointed Captain of Company H, 157th Indiana Volunteer Infantry, serving until the regiment was mustered out. In 1900 he was elected Lieutenant Governor, presiding over the Senate during the Sixty-second and Sixty-third General Assemblies. He has been prominently identified with state politics since he reached his majority, and was elected to Congress from the twelfth district in 1904. As presiding officer of the Senate, Governor Gilbert has given evidence of unusual qualifications for the duties of a presiding officer. He was a member at large of the Commission, and was also its President. He presided over the meetings of the Commission, always keeping in close touch with all detail work of the Committees which he appointed. His judgment and suggestions were highly regarded. At the dedication of the Indiana Building he responded to an address of Governor Durbin, and presided at the exercises on Indiana Day, September 1.

$\mathrm{Mr}$. Gilbert at the present time resides at Fort Wayne, Indiana, and is engaged in the practice of law. 


\section{Henry W. Marshall}

Henry W. Marshall, one of the members-at-large of the Indiana Commission, resides at Lafayette, Indiana, and is one of the successful business men of the city. He was born near Springfield, Ohio, January 29, 1865. His parents moved when he was six years old to Montmorenci, Indiana. He represented Tippecanoe County in the Sixty-first, Sixty-second and Sixty-third General Assemblies, and during the Sixty-third session was speaker of the House. His services as a representative were such as reflected credit upon himself and his constituents, and as a presiding officer he won the confidence and esteem of all. He is President and general manager of the Western Construction Company. The success of this concern is largely due to his management $\mathrm{He}$ is also President and manager of the Diamond Flint Company. He is a member of the Columbia and University Clubs of Indianapolis, and the Lincoln and Lafayette Clubs of Lafayette. Mr. Marshall was Vice-President of the Indiana Commission and presided over the Commission at business meetings in the absence of the President. He was also a member of several important committees on arrangements and entertainments, being Chairman of the Committee on Dedication, and the great success of this event was largely due to his efforts. He took great interest in the work of the Commission and his judgment and suggestions were of much value.

Mrs. Marshall served as hostess of the Indiana Building from October 1 to 10 , assisted by Mrs. Samuel T. Murdock, of Lafayette. 


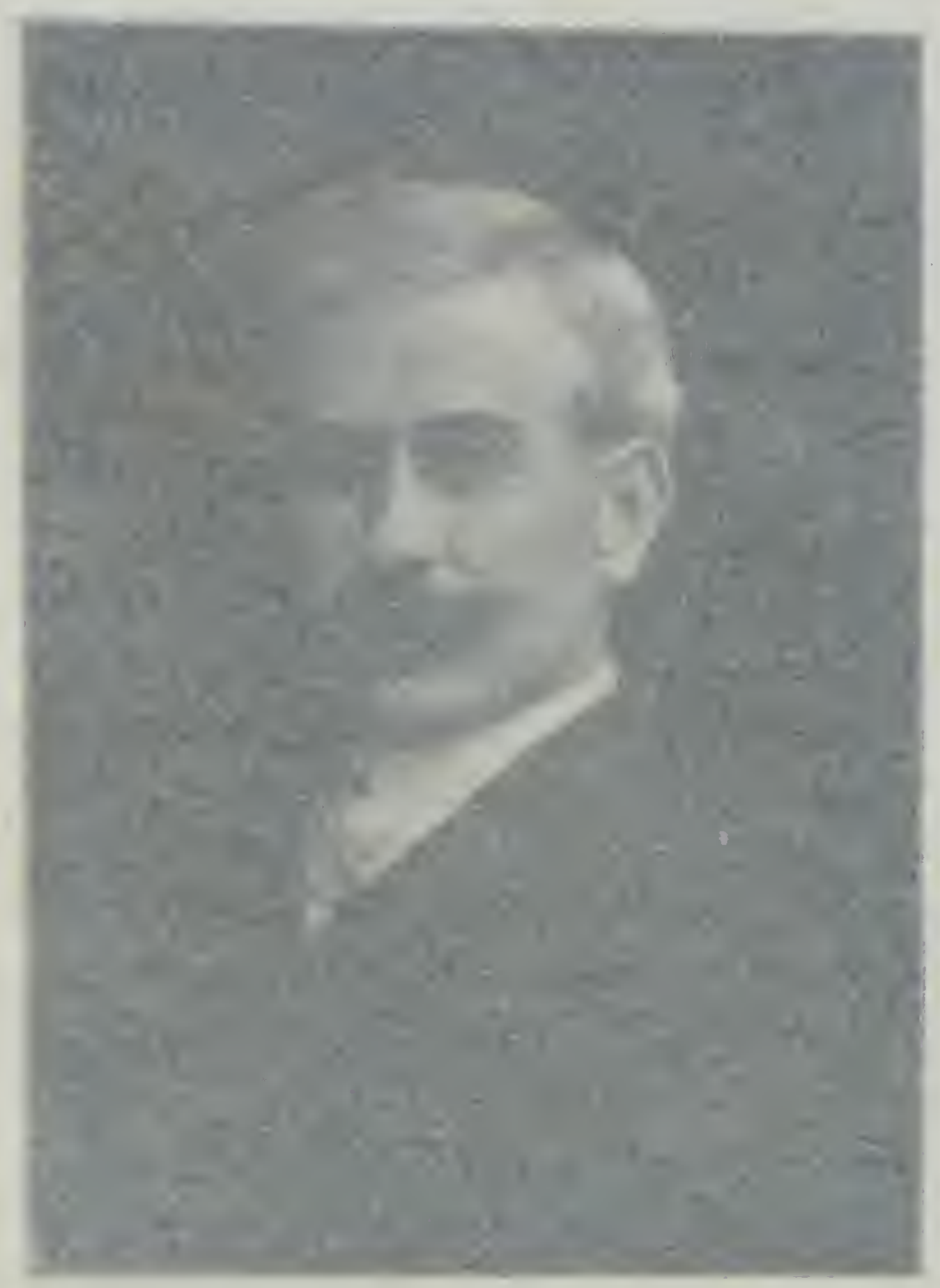

HENRY W. MARSHALL, Vice-President of Commission, Commissioner at Large. 


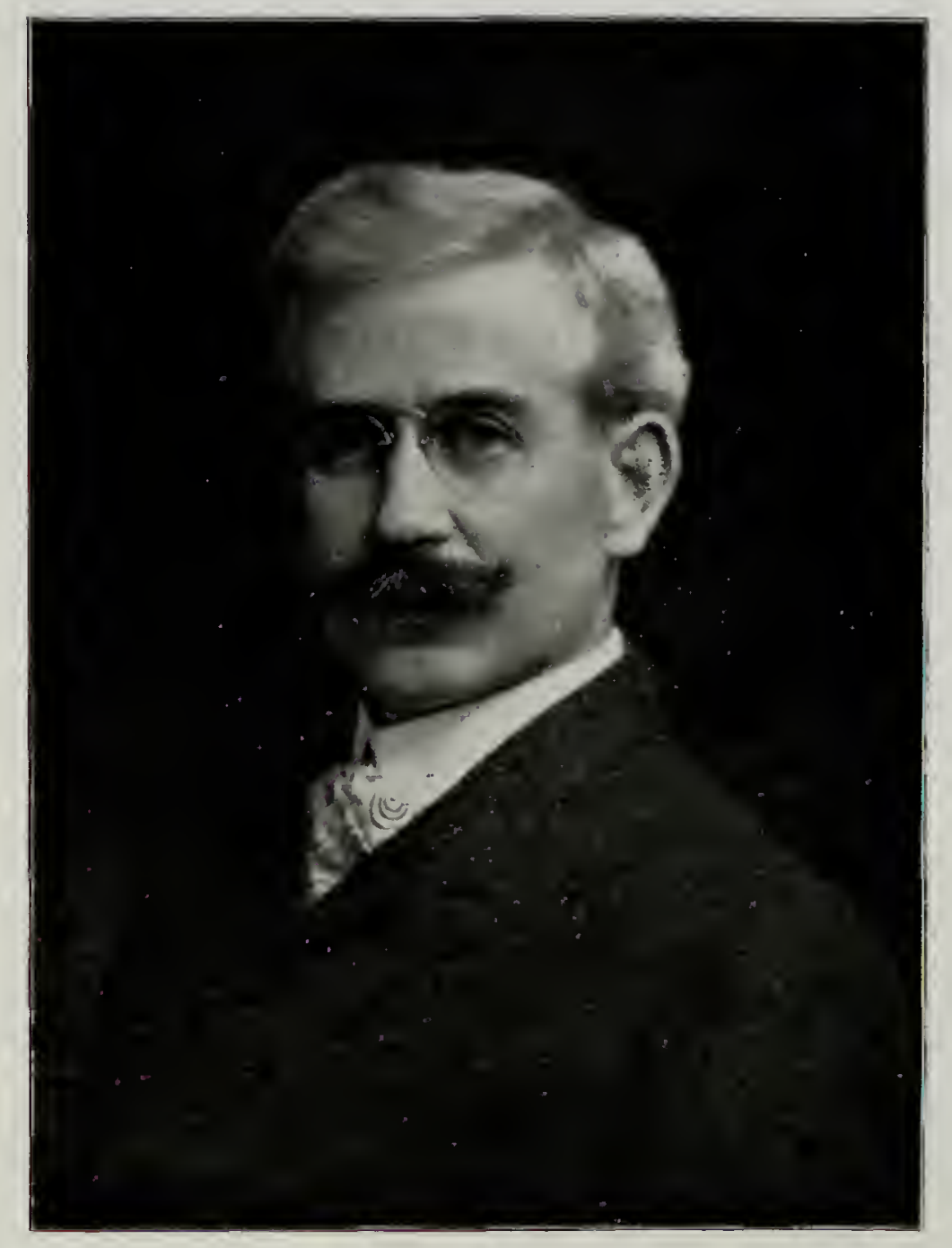




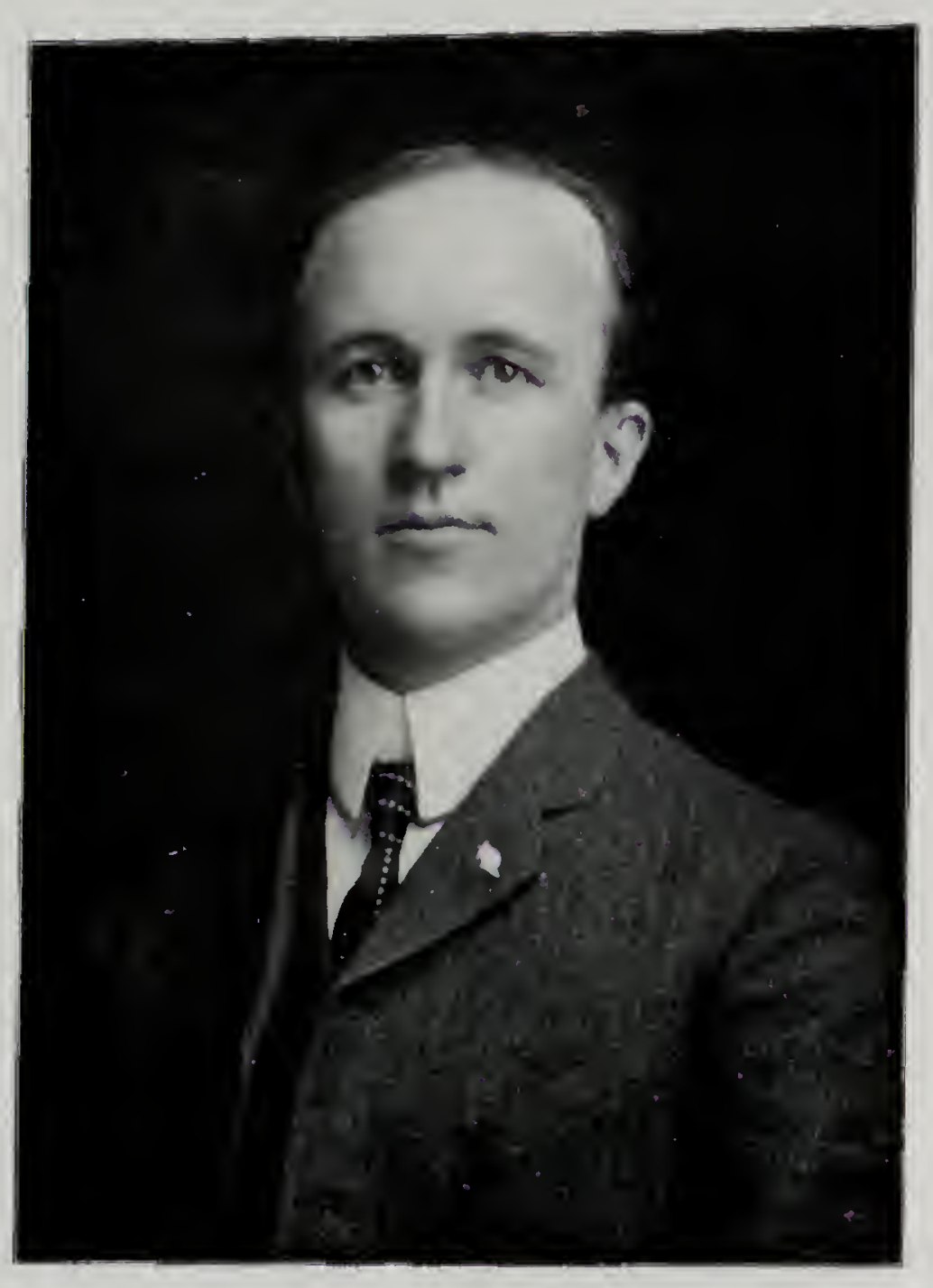




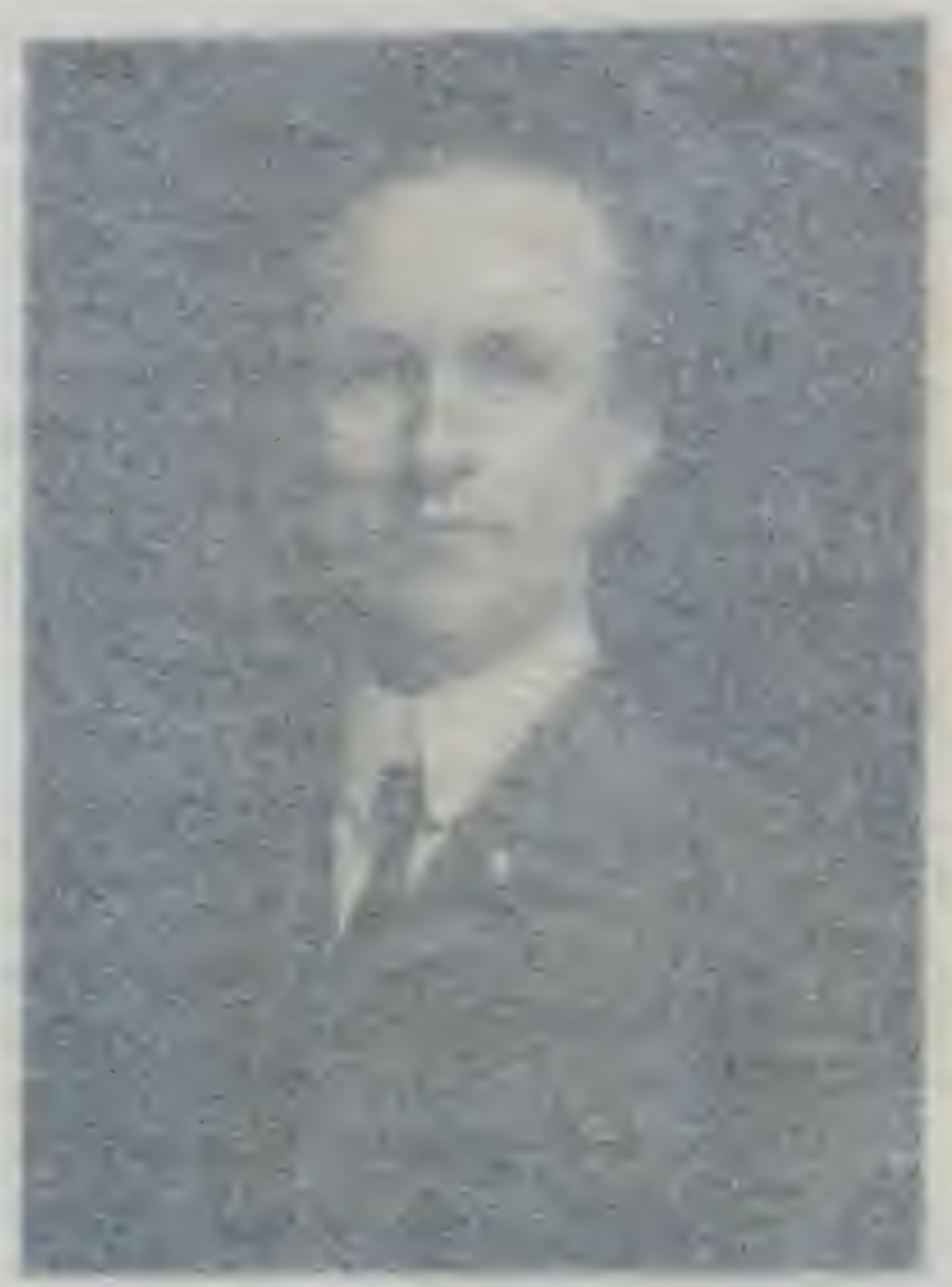

JAMES W. COCKRUM, Secretary of Commission, Commissioner from the First District. 


\section{James W. Cockrum}

James W. Cockrum was born on August 22, 1871, in Oakland City, Indiana, where he still resides. He received his education in the schools of his home town, and entered upon his business career as a commercial traveler, selling school furniture and supplies from 1887 to 1890, at which time he embarked in business for himself. He organized the Indiana School Furnishing Company, which he operated in connection with a large job printing office. In 1893 he established the Oakland City Journal, now one of the best semi-weekly newspapers in Southern Indiana, which he still owns and operates. In addition to his newspaper property he is interested in manufacturing and other enterprises. He was married to Miss Agnes Pritchett, at Carmi, I11., September 24, 1891. They have one child, a daughter. He is active in newspaper work and in May, 1904, was elected Recording Secretary of the National Editorial Association of the United States at the annual meeting at St. Louis.

Mr. Cockrum was elected Secretary of the Indiana Commission as a recognition of ability and thoroughness, and has since proven his fitness both as a member and as Secretary. He represented the First Congressional District on the Commission, was one of the active members and was never recorded absent from a business meeting of the Commission. He was a member of several important committees, viz: Committee in charge of Press Parliament Week, May 15 to 22; Indiana Press Day, June 10; Dedication of Indiana Day, June 3; and Indiana Day, September 1 , and other committees of less importance, contributing largely to their success. He gave the affairs of the Commission a great deal of time and was interested in the work, both as Secretary and as a member of the Commission.

Mrs. Cockrum was hostess of the Indiana Building from July 1 to 10, and was assisted by Mrs. Ella C. Wheatley, of Oakland City. 


\section{W. W. Wicks}

W. W. Wicks is a native Hoosier, born in New Albany. He served during the civil war in the 20th Indiana Battery. At the close of the war he moved to Bloomington, Indiana, where he entered the mercantile!business, first starting a small dry goods store. Through enterprise and energy his business prospered and developed, and at the present time Mr. Wicks is operating one of the largest department stores in the Southern part of the State. He is also largely interested in the stone business, in which he has been very successful. He is the principal owner of several valuable stone quarries, and at the present time is President of four stone companies, viz: Hunter Valley Stone Co., Star Stone Co., Mather Stone Co., and Perry Bros. Stone Co. He is interested in other successful enterprises in his community.

Mr. Wicks was Chairman of the Committee on Building Stone, and through his knowledge and energy, Indiana's building stone exhibit was in a class by itself. A detailed report of this exhibit, which reflects credit upon the committee having it in charge, will be found elsewhere in this publication. Mr. Wicks was also a member of the Executive Committee, and the Committee on Woman's Work and Literature and Fine Arts.

Mrs. W. W. Wicks served as hostess of the Indiana Building from September 1 to 10, and was assisted by her daughter, Mrs. G. W. Cunningham. 


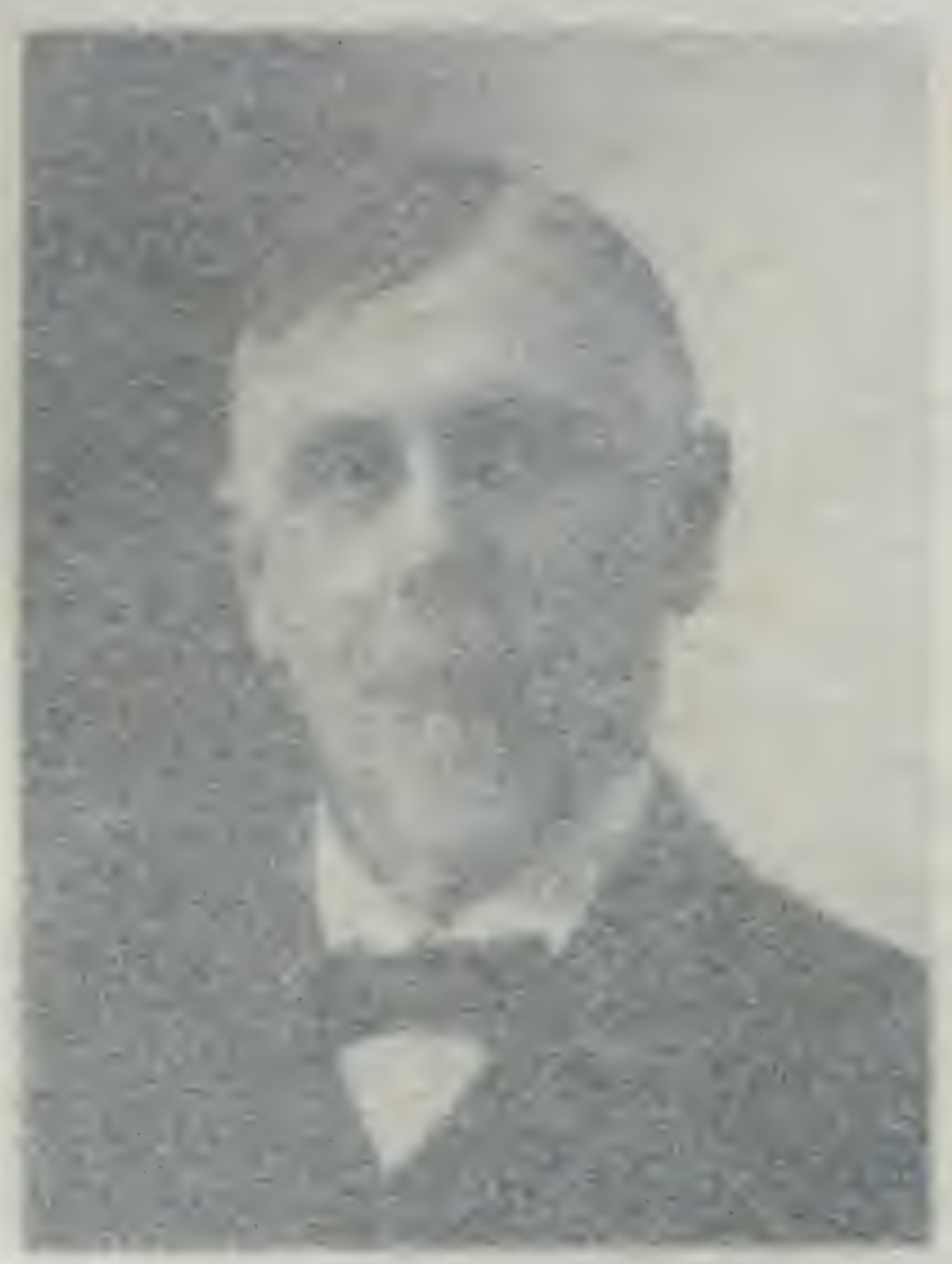

W. W. WICKS,

Commissioner from the Second District. 


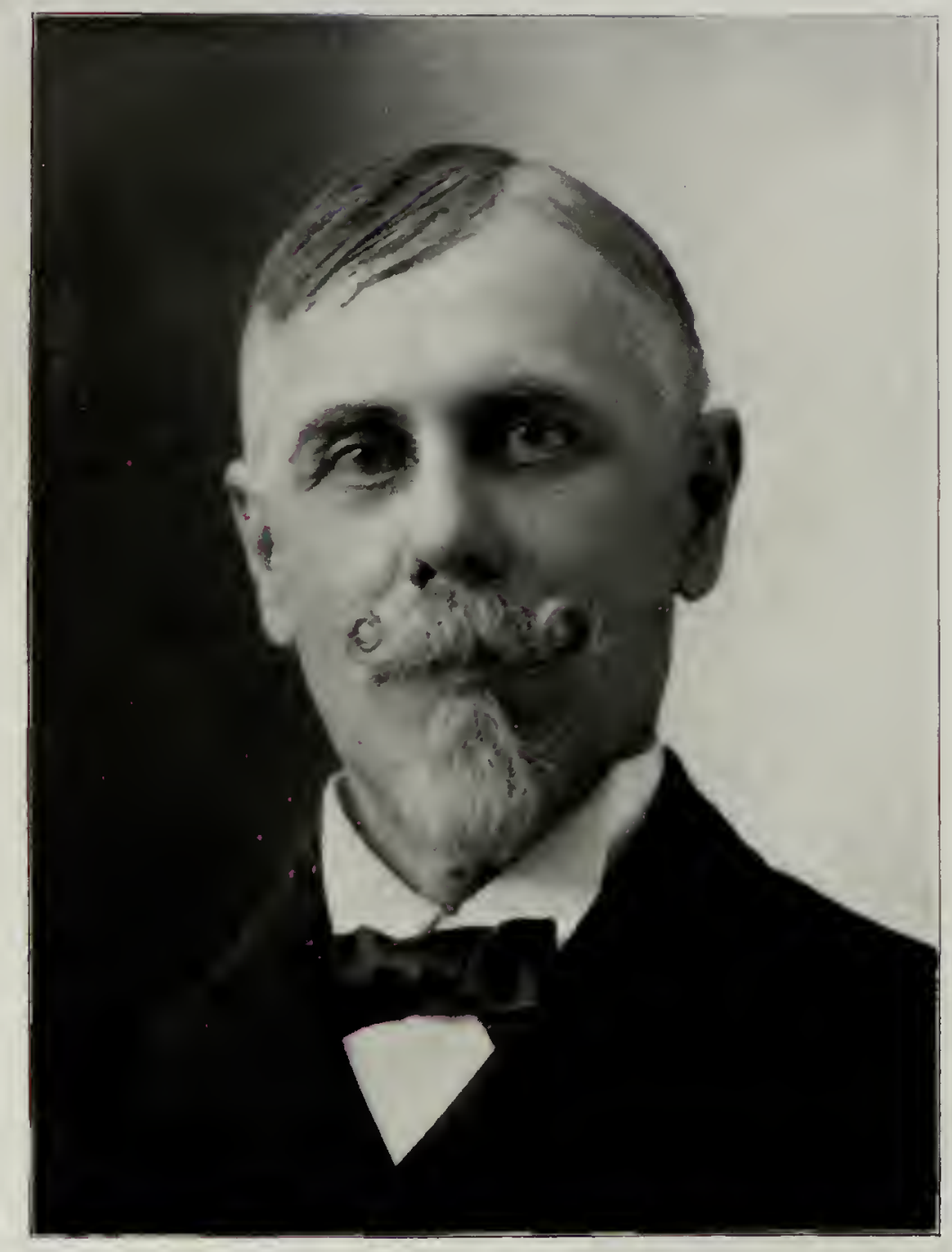






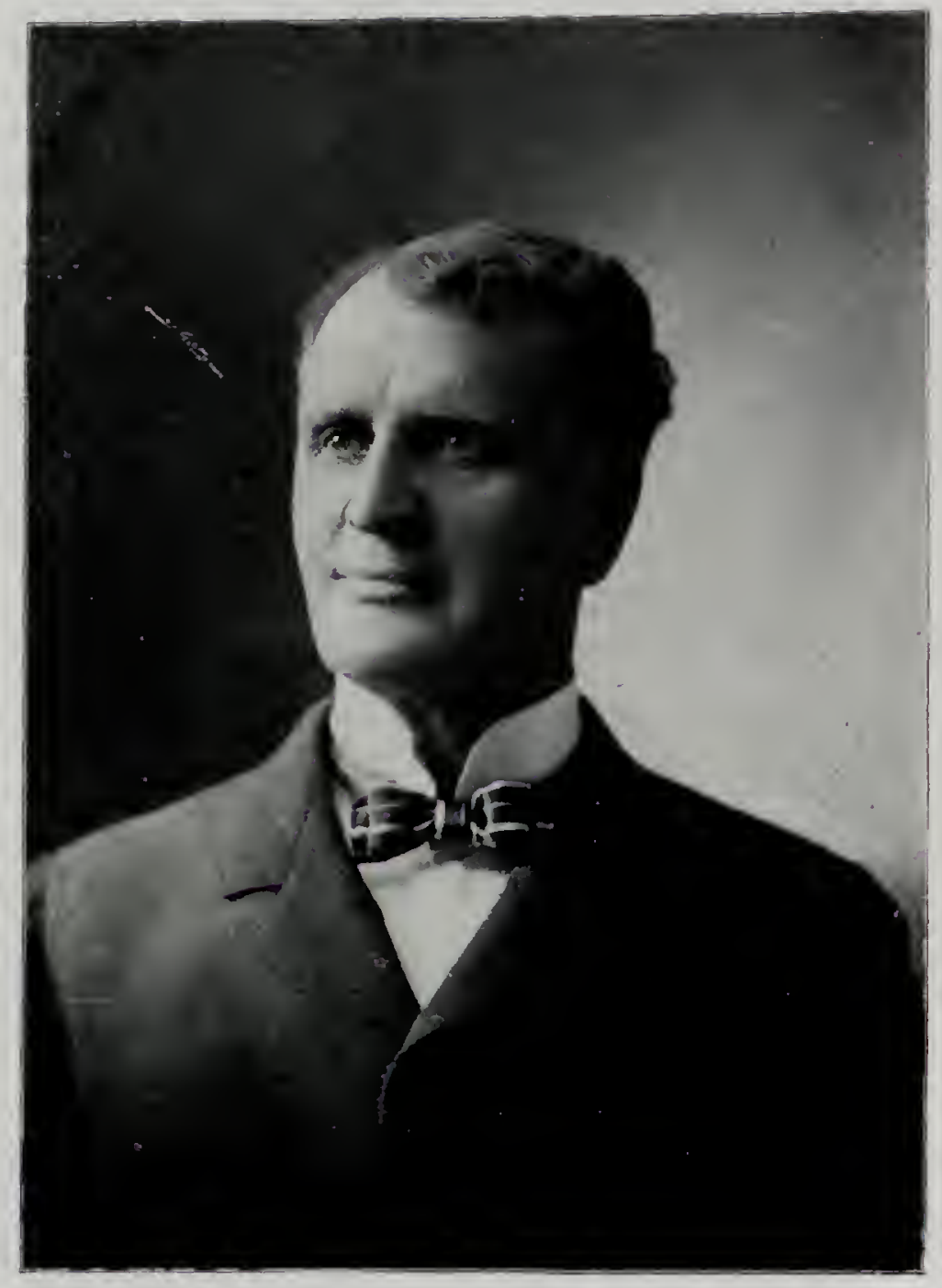




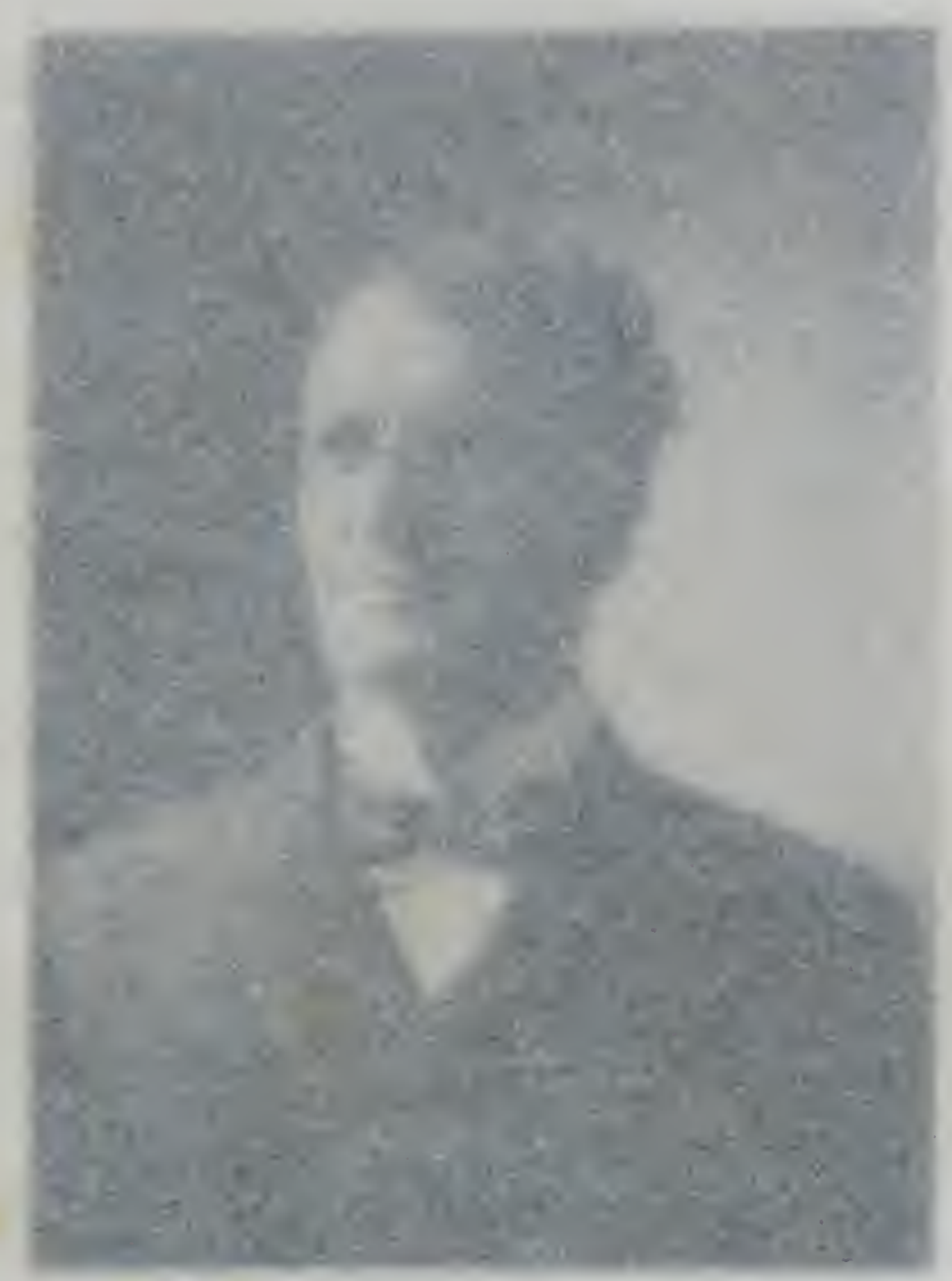

WARDER W. STEVENS,

Commissioner from the Third District. 


\section{Warder W. Stevens}

Warder W. Stevens, who represented the Third Congressional District on the Indiana Commission, was born in Hardin County, Kentucky, September 30, 1845. Accompanying his parents when a small boy, they located near Corydon, Indiana. Having had the great advantage of a farm life and a country school, Mr. Stevens completed his education at the State University at Bloomington. He graduated in the law department in 1867 and then located at Salem, where he was for twelve years engaged in the newspaper business, and served one term as county auditor for his county. For the last twenty years Mr. Stevens has been engaged in agricultural and horticultural pursuits with the greatest success, having one pear orchard of 90 acres, containing 12,000 trees and an apple orchard of over 1500 trees. He was a member of the State Board of Agriculture for several years, and in 1899 served as its President He has also been President of the State Board of Horticulture for three years, and was the nominee of the Democratic party for Lieutenant-Governor in 1904. It was because of the experience and success of Mr. Stevens in agriculture and horticulture that the Commission saw fit to place him at the head of the committee representing these interests. The organization and installation of these exhibits and the development of the livestock exhibit was under the direction of this committee. Mr. Stevens' experience and knowledge in these departments was of value to the Commission as is shown in the detailed report of the exhibits in charge of this committee, and no man ever gave harder thought or closer attention to any undertaking than Mr. Stevens gave to his work. He was also a member of the Committees on Mines and Mineral Products, and Electrical Appliances.

Mrs. Stevens was hostess of the Indiana Building from August 20 to September 1, and was assisted by her daughter, Miss Warda. 


\section{William H. O’Brien}

William H. O'Brien, of Lawrenceburg, is one of the best known and most successful business men in the State. He was born in the city where he now resides August 22, 1855, and after receiving a common school education at his home, he attended DePauw University during the sophomore year. He was elected mayor of his home city in 1885 , and was re-elected in 1887, 1889,1891, 1898. In 1902 he was elected to the State Senate, and representing Franklin, Dearborn and Ohio counties in the Sixty-third and Sixty-fourth General Assemblies, he served with distinction and credit to his party and district. He is at the head of his party in the state and is at the present time the chairman of the Democratic State Committee. He is engaged in the banking business and is interested in other financial undertakings in his comnunity.

Mr. O'Brien was the member of the Indiana Commission from the Fourth Congressional District and was chairman of the Committee on Mines and Mineral Products. He organized, collected and installed the coal exhibit, which was the best coal exhibit in the Mines and Metallurgy Building, which is further described in this publication.

Mr. O'Brien was also a member of the Auditing Committee and the Committee on Agriculture, Horticulture and Live Stock, and State Building, taking especial interest in the work of these committees as well as his own, and adding to their success. Mrs. O'Brien was hostess of the Indiana Building from September 1 to 10, and was assisted by Mrs. J. M. Bauer. 


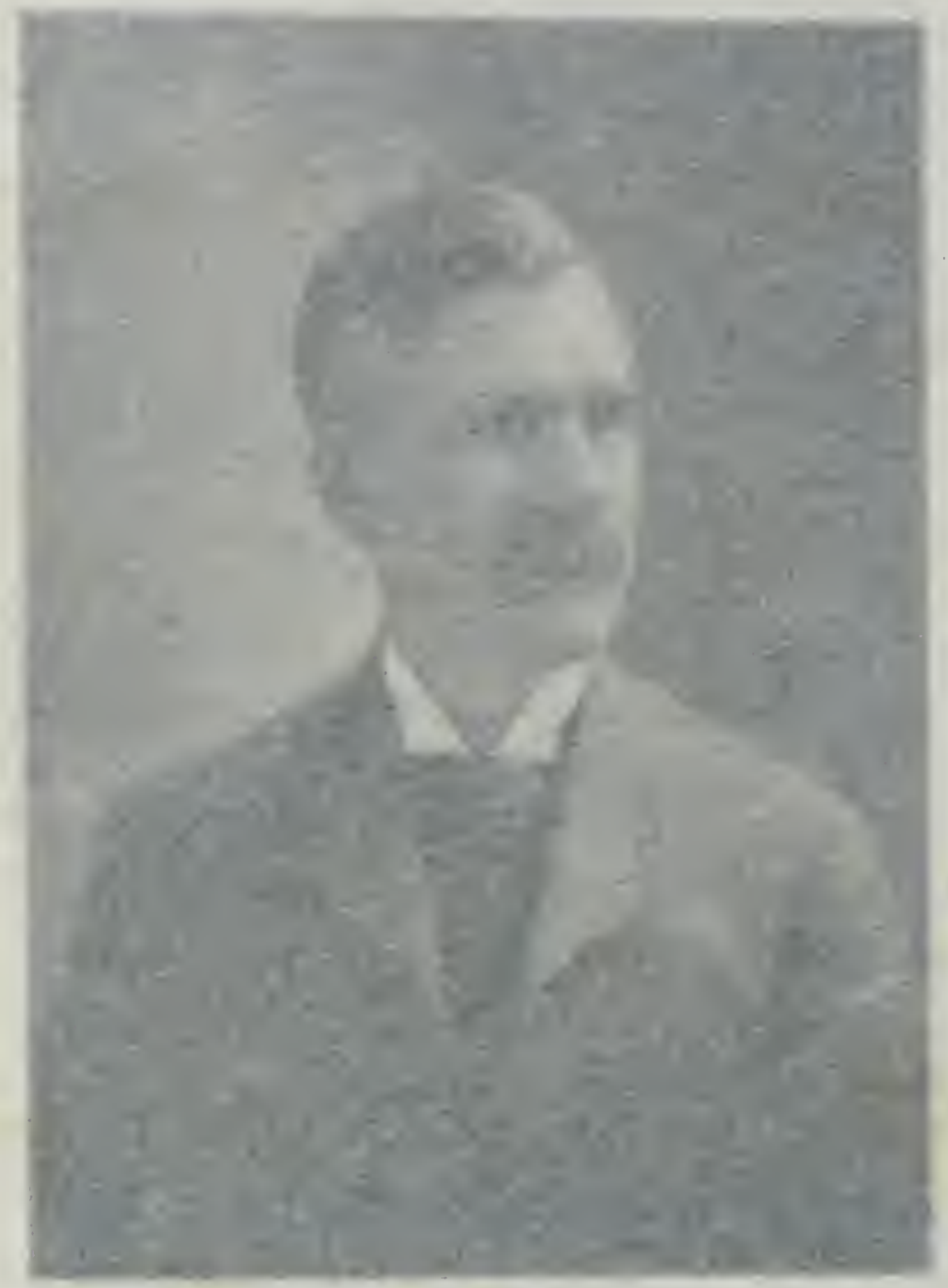

WILLIAM H. O'BRIEN,

Commissioner from the Fourth District. 


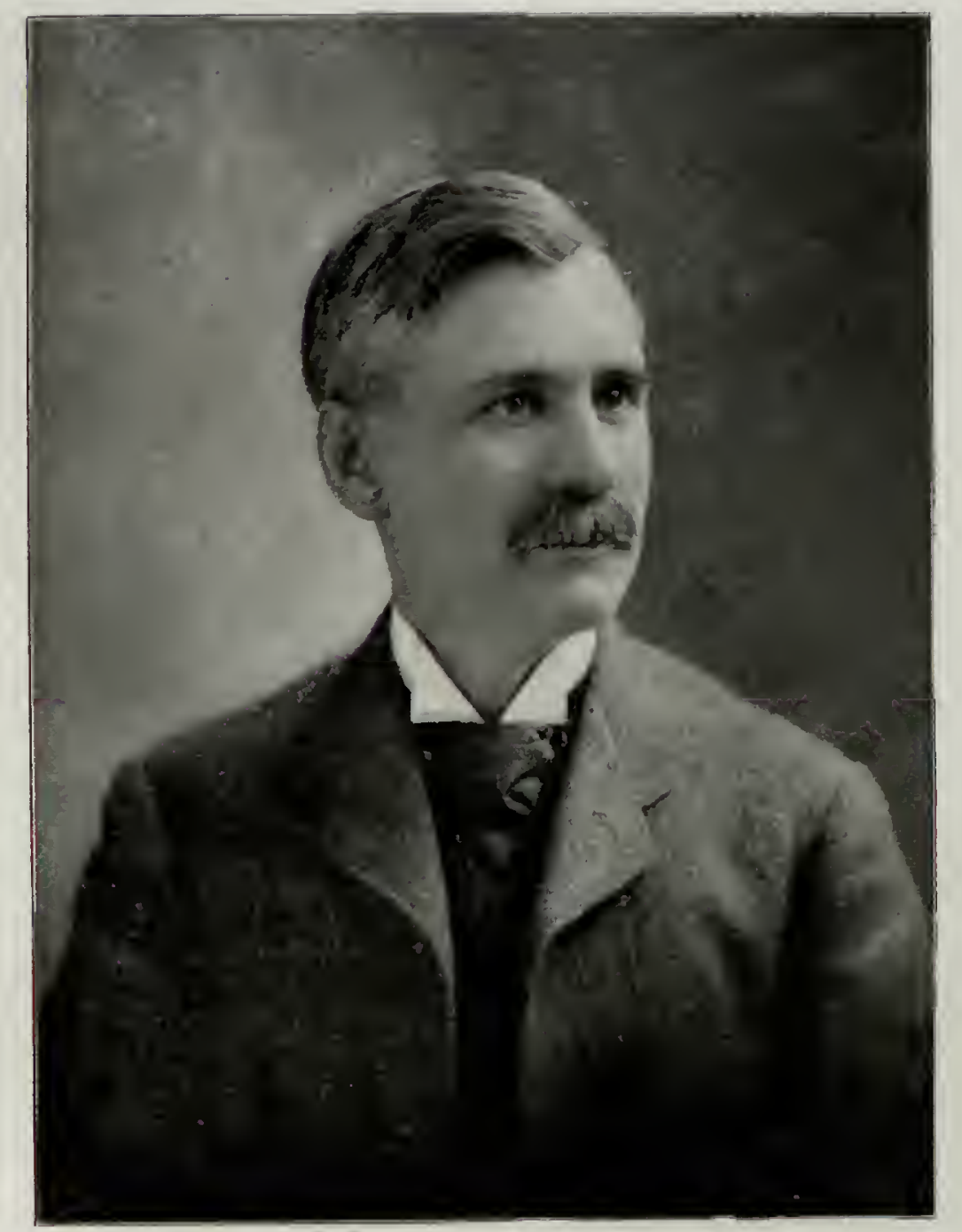




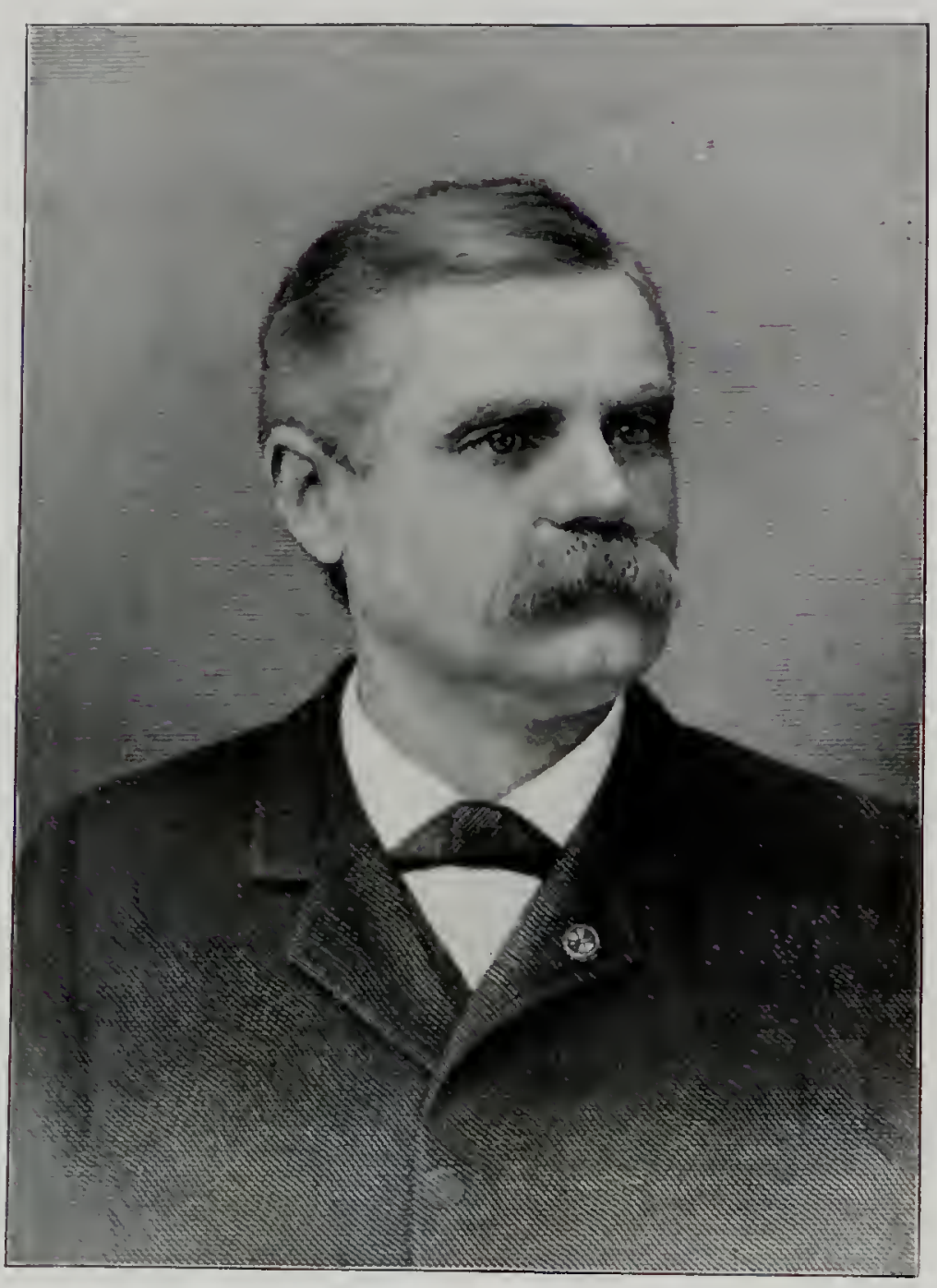




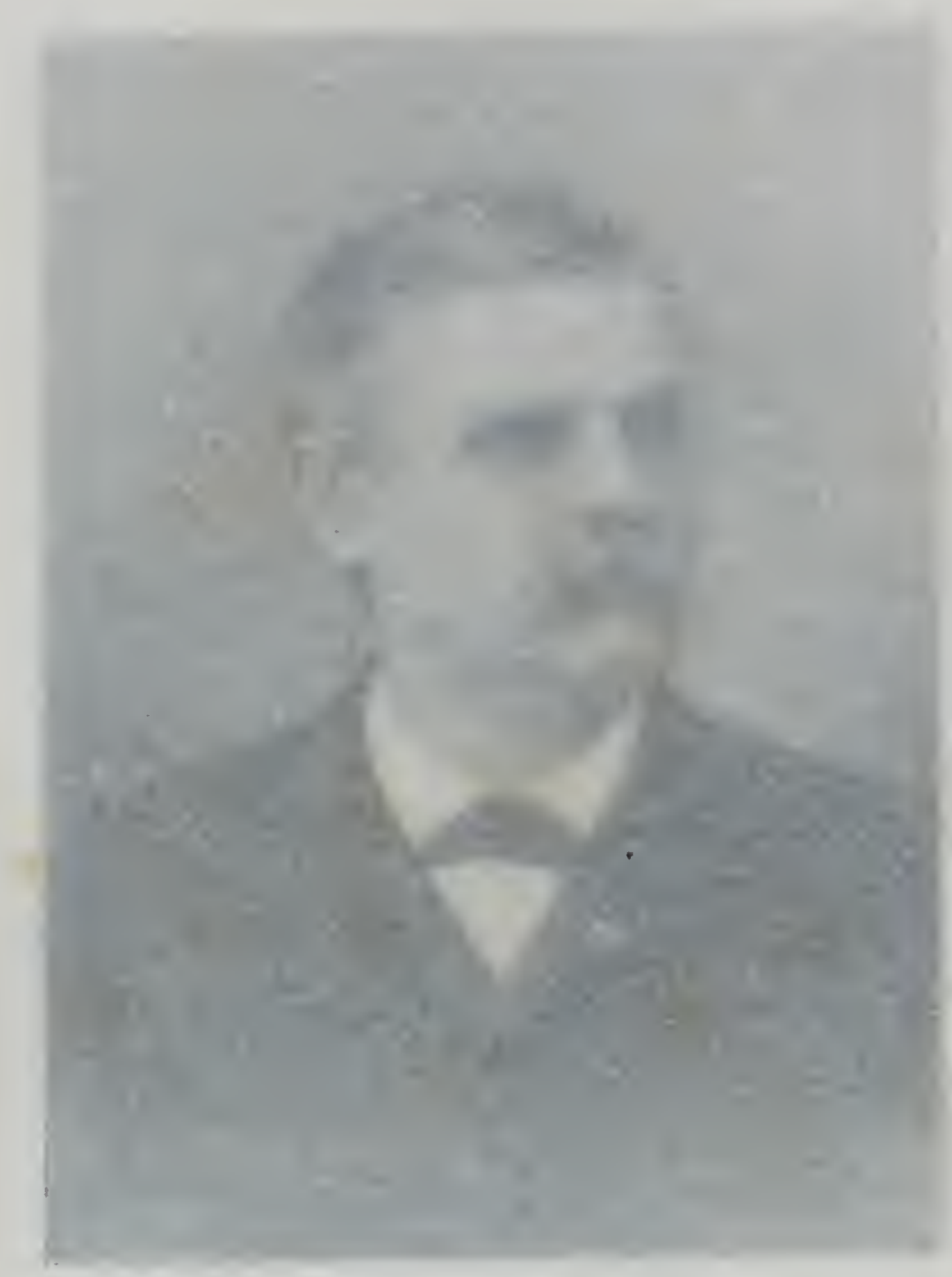

CRAWFORD FAIRBANKS,

Commissioner from the Fifth District. 


\section{Crawford Fairbanks}

Crawford Fairbanks, the well known Terre Haute manufacturer and capitalist, who represented the Fifth Congressional District on the Commission, was born April 25, 1843, in the city of Terre Haute, and was raised on his father's farm, where he received a common school education. He entered the army of the war of the Rebellion before reaching his majority, and was commissioned First Lieutenant by Governor Morton in the 129th Indiana Volunteers. His regiment was with General Sherman in the famous march to the sea, taking part in many hard fought battles. On retiring from the army he returned to Terre Haute and engaged in the grain business, later organizing the firm of Hulman \& Fairbanks Distilling Co. A few years later Mr. Fairbanks purchased the entire plant and organized the Terre Haute Distilling Co., the largest concern of the kind at the time of its organization in the world. It is still in existence, and its wonderful success is due to the efforts and management of Mr. Fairbanks, who has been its President since its start.

Mr. Fairbanks' business efforts have not been confined to this particular channel, but he is constantly branching out in new fields of investment, and is today actively connected with more than twenty manufacturing and business enterprises located in the different states of the Union, many of them with a capitalization of millions. Mr. Fairbanks' career is an example of what may be accomplished and achieved by industry and energy. He embarked in the business world when a boy, his capital being a strong will and business qualifications. While yet in the prime of life he is one of the best known, most successful, and wealthiest men in the state. His success has not been attended by any degree of selfishness. His liberal public spirit is recognized and appreciated by all. Mr. Fairbanks has long been active in the state organization of the Democratic party. In 1888 he was offered the nomination on the Democratic ticket for Congress in his district, but declined the tender. He was the chairman of the Executive Committee of the Indiana Commission. His business experience and good judgment were of great benefit to the successful work of the Conimission. He was also a member of the Committee on Electrical Appliances. 


\section{David W. Kinsey}

David W. Kinsey, the chairman of the Commission's Committee on Publicity and Promotion, was born near Millville, Henry County, Indiana, February 1, 1846. He received his education in the New Castle schools and taught for several years; served in the civil war, enlisting as a private in Company G, 139th Regiment of Indiana Volunteers; studied law and was admitted to the bar in 1869, but was soon afterwards appointed Clerk of Henry County, serving in the capacity of County Clerk and Deputy for over four years. When the Citizens' State Bank of New Castle was organized, Mr. Kinsey was appointed to the position of cashier, in which position he has served for thirty years, and which he still holds. He is a member of the Board of Directors of the bank, and has served as a member of the Board of Education in his city for fifteen years, and is also connected with many business enterprises of New Castle and vicinity.

He represented the Sixth Congressional District on the Commission and was chairman on one of the important committees. Mr. Kinsey and his committee maintained a press and publicity bureau at headquarters at Indian. apolis from June 1, 1903, until March 15, 1904. A weekly bulletin was issued and every weekly and daily news. paper of the state was supplied with information concerning the work of the Commission.

Mr. Kinsey was also a member of three other important committees, viz: Education, Building Stone an State Building, on all of which he rendered very efficient service.

Mrs. Kinsey was hostess of the Indiana Building from June 10 to 20, and was assisted by her daughter, Mr: Harry E. Jennings. 


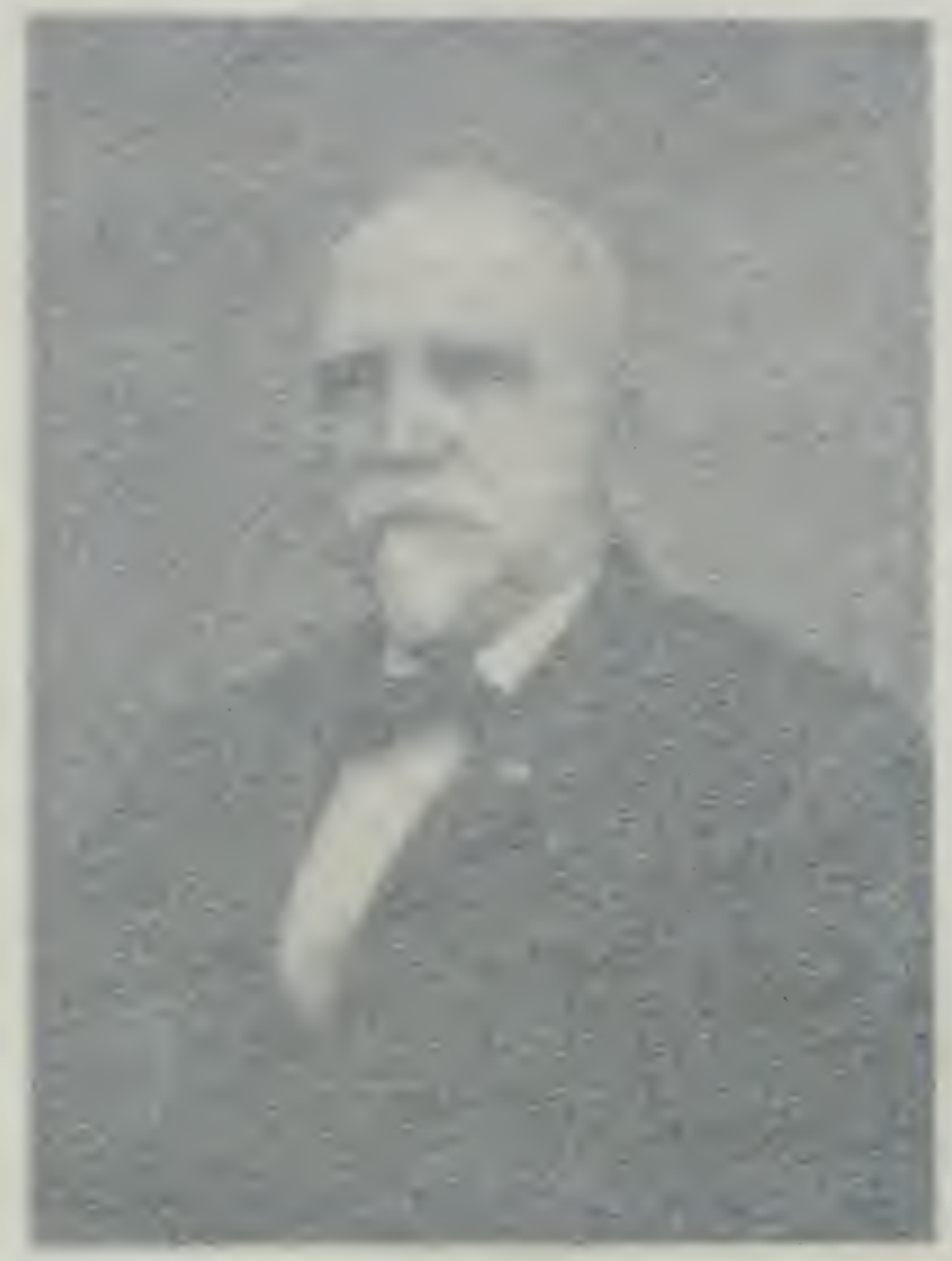

DAVID W. KINSEY,

Commissioner from the Sixth District. 


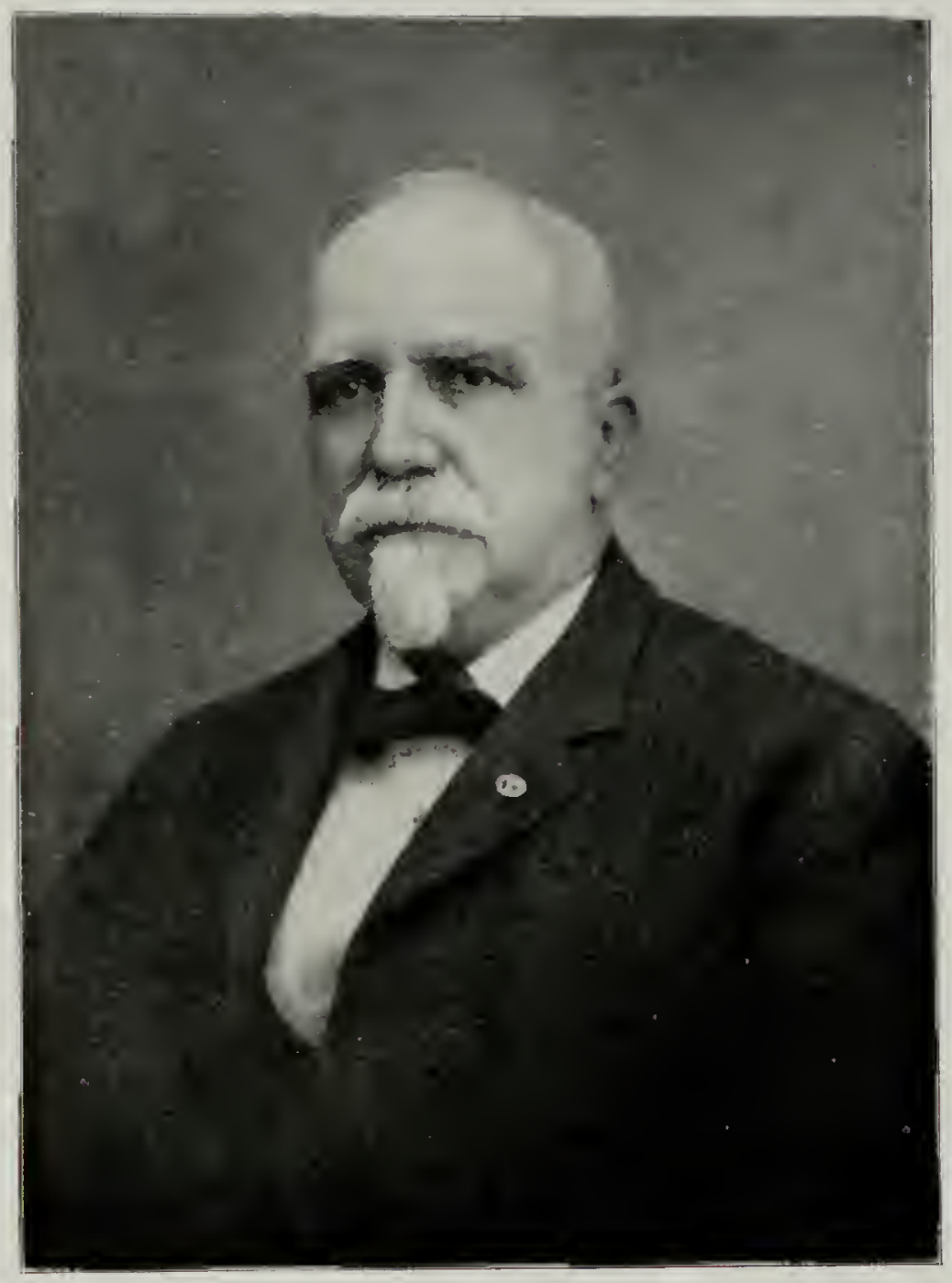





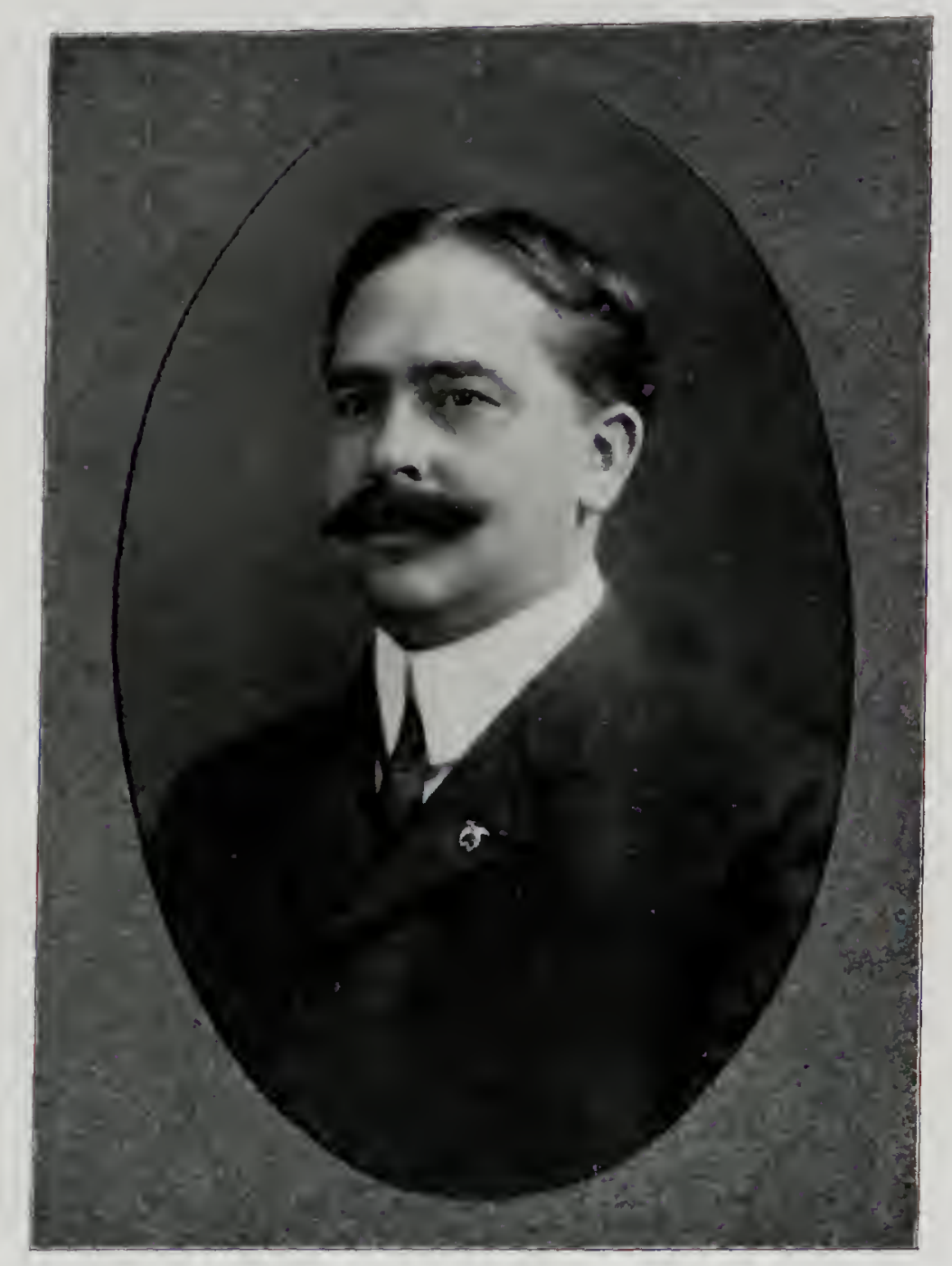




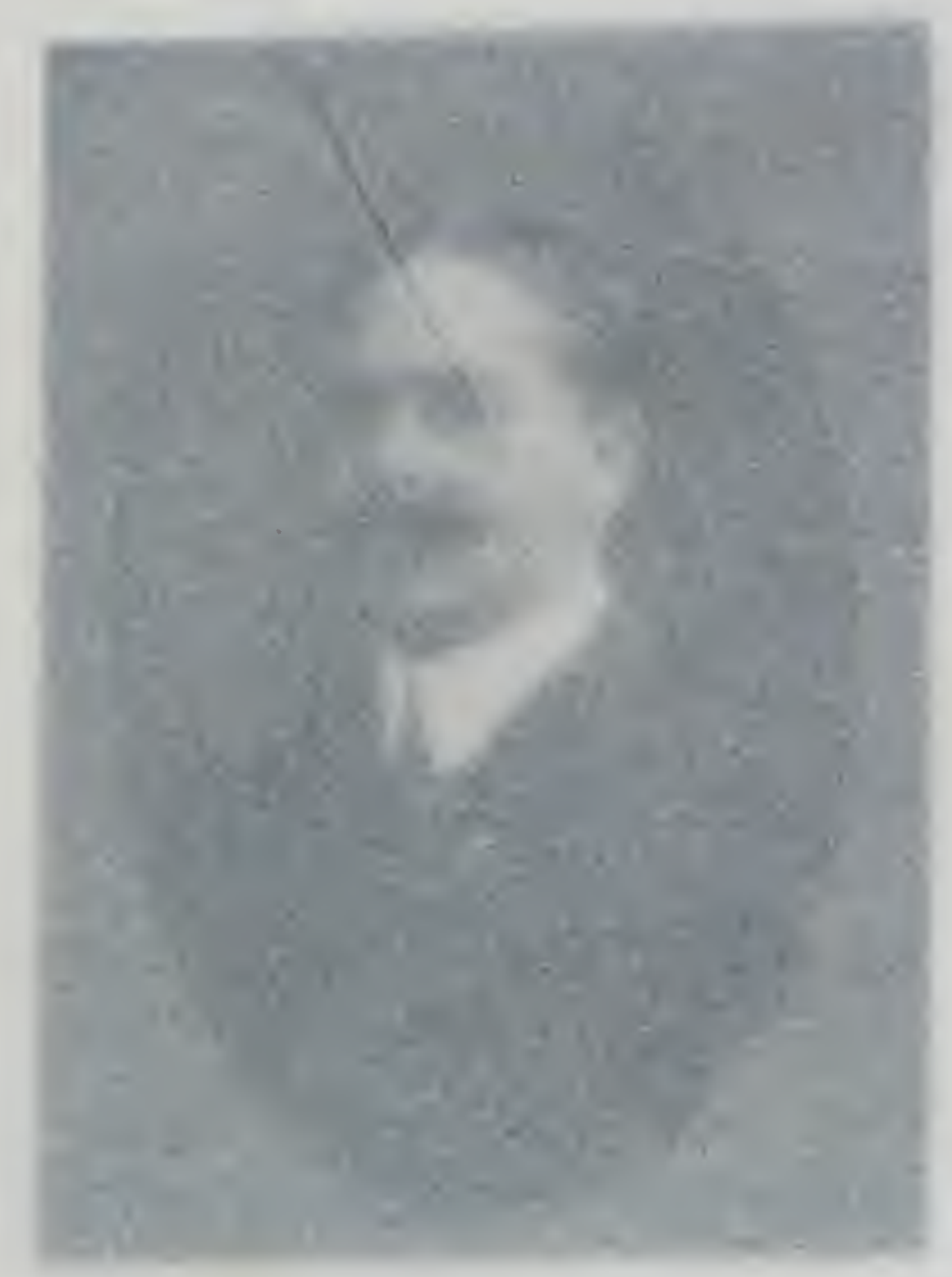

NELSON A. GLADDING,

Commissioner from the Seventh District. 


\section{Nelson A. Gladding}

Nelson A. Gladding, the Indianapolis member of the Commission, is one of the capital city's best known business men. He was born in Providence, R. I., July 8, 1863, and moved to Champaign, I11., in 1874, where he completed his school education. He began his business career in Paxton, Ill, but soon removed to Indianapolis, where he accepted a position as bookkeeper with a large mercantile institution. From 1883 to 1884 he was traveling auditor for a large telephone company, with headquarters at Kansas City, and from 1884 to 1885 he was chief clerk of one of the chief mercantile concerns of Providence, R. I. In January, 1886, he became traveling representative for E. C. Atkins \& Co., of Indianapolis, Saw Manufacturers, and was soon made manager of a branch house in Memphis, Tenn. This position he held for twelve years. January 1,1898, he was elected Secretary and Sales Manager of the company, with headquarters at Indianapolis, and in 1901 was elected Vice-President and Secretary of the company, which position he now holds.

Mr. Gladding was the chairman of the Committee on Manufactures, and was in close communication with the manufacturers of the state, being successful in encouraging this important department of industry with the result that it was well and creditably represented at the Exposition He was also chairman of the Committee on Forestry, and a member of the Executive and Auditing Committees.

Mrs. Gladding was hostess of the Indiana Building from July 10 to 20, and was assisted by her sister, Mrs. Gates of Indianapolis. 


\section{Frank C. Ball}

FRANK C. BALL, Chairman of the Committee on State Building, resides at Muncie, Indiana, and represented the Eighth Congressional District on the Commission. He was born in Greensburg, Ohio, November 24, 1858. When he was ten years of age his parents moved to Canandaigua, N. Y., at which place he attended the public schools and the Canandaigua Academy.

At the age of 21 he embarked in the manufacturing business with his brothers at Buffalo, N. Y., manufacturing sheet metal goods in a small way. The business grew rapidly and a few years later they added the manufacture of glass bottles and jars. On the discovery of natural gas in Delaware County, Indiana, in the year 1887, they removed their plant to Muncie, it being the first to locate in the gas belt. Their business has been very prosperous since locating in Indiana, at the present time employing over 2,000 men, and producing about 500,000 gross Mason fruit jars and bottles per year, or 300,000 per day. They supply a large percentage of all the jars used in the United States and export a great many.

Mr. Ball is extensively interested in other industries in the state and is a very successful financier. He gave much thought to the plans of the Indiana Building, a detailed description of which is given elsewhere in this publication.

Mr. Ball was also a member of the Committees on Manufacturers, Forestry, and Woman's Work.

Mrs. Ball was hostess of the Indiana Building from November 1 to 10, and was assisted by Mrs. Lucius L. Ball. 


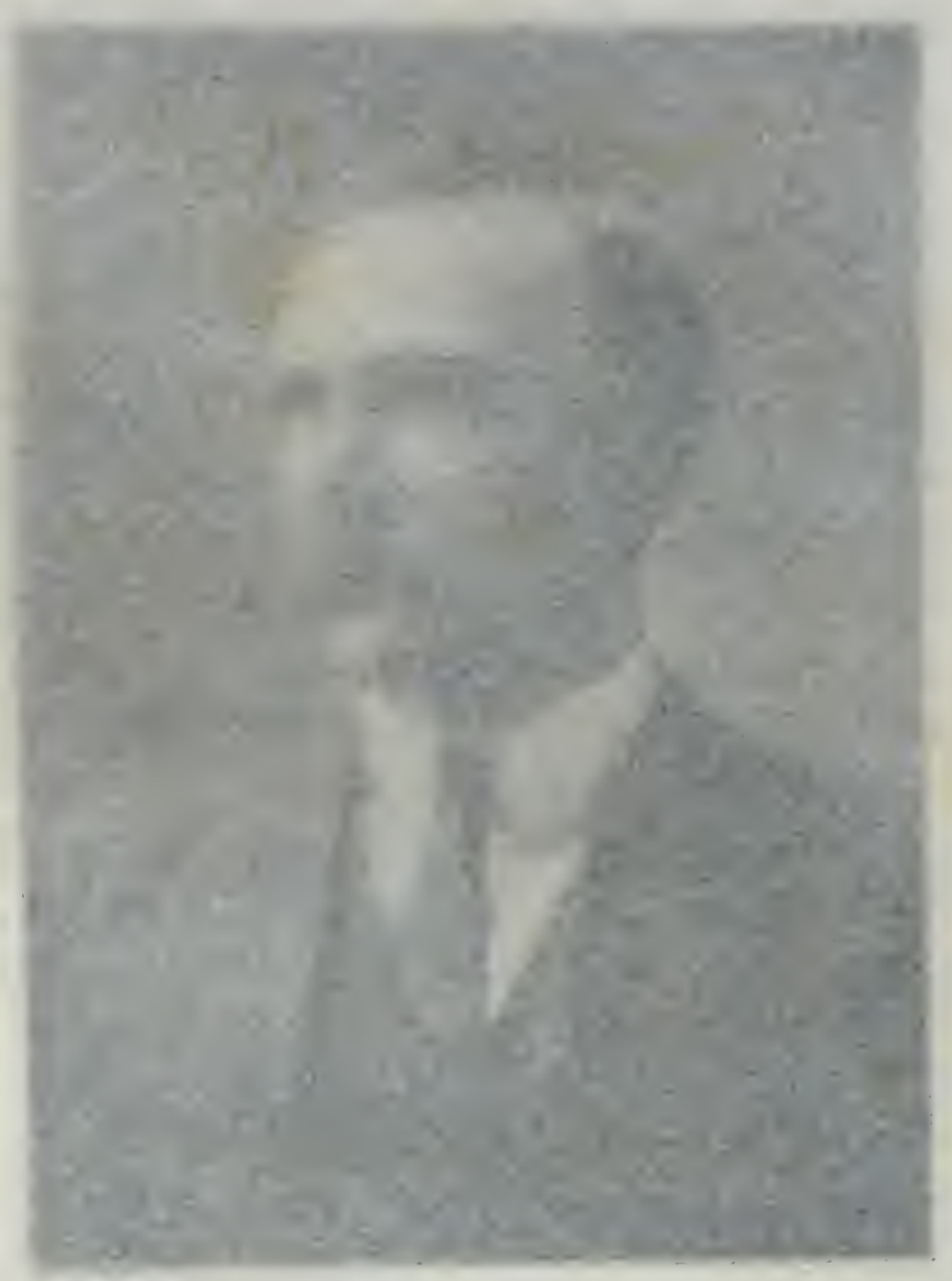

FRANK C. BALL,

Commissioner from the Eighth District. 


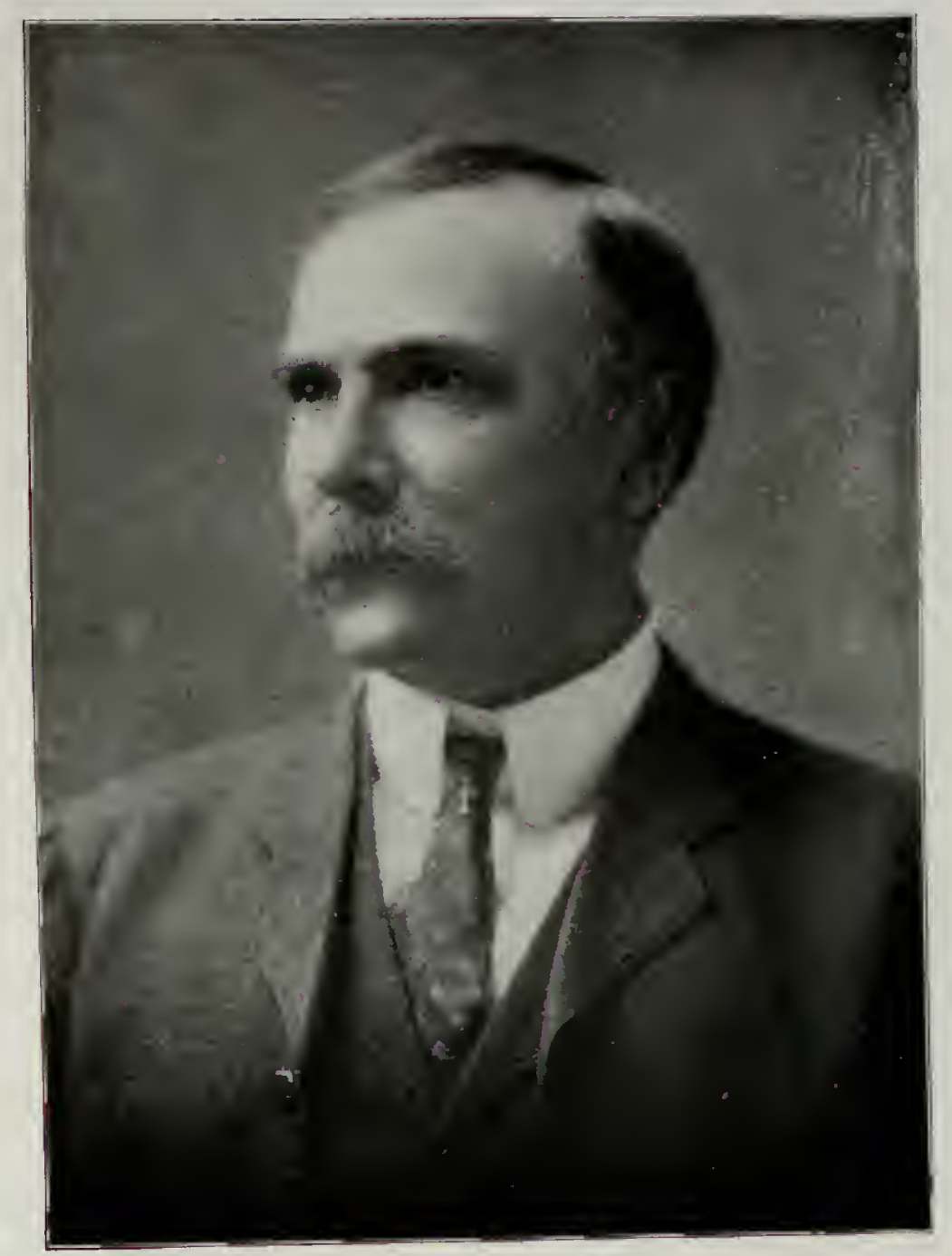




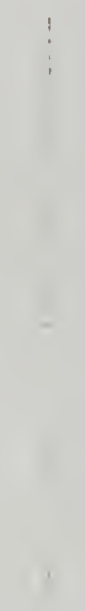





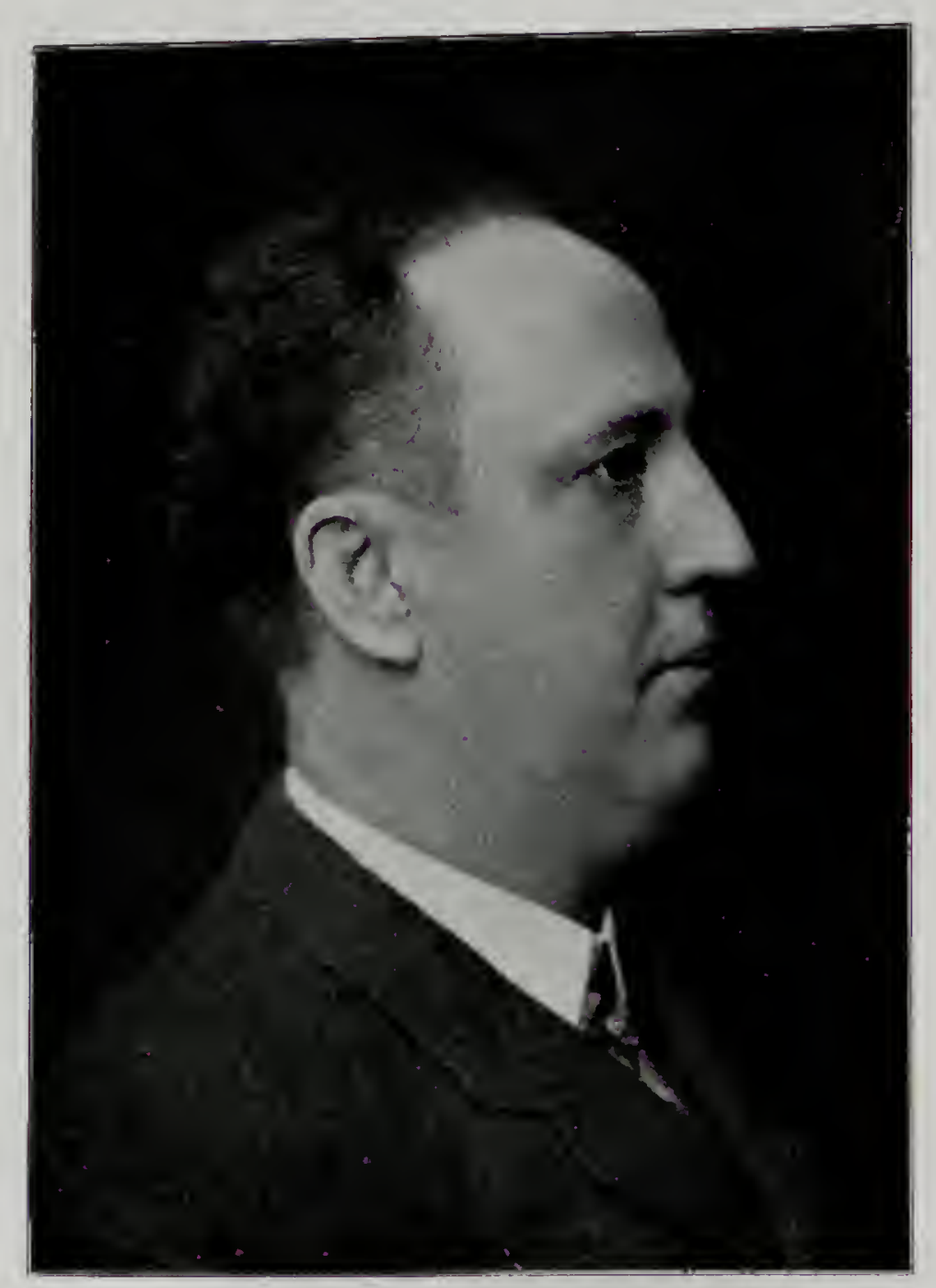




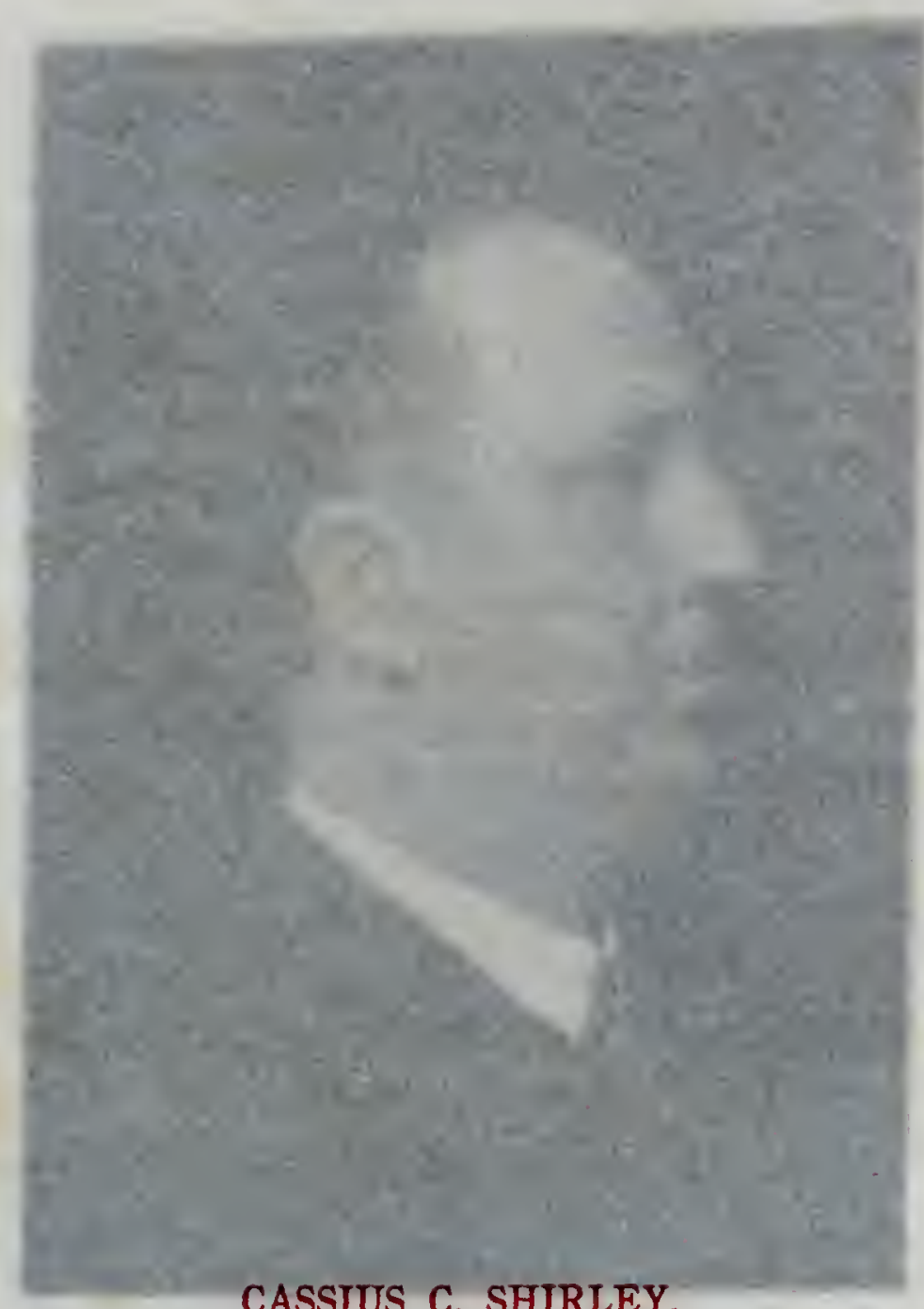

Commissioner from the Ninth District. 


\section{Cassius C. Shirley}

Cassius C. Shirley was born at Russiaville, Howard County, Indiana, November 28, 1859. His parents soon removed to New London, in the same county, where Mr. Shirley attended school, finishing the high school course. In 1877 and 1878 he attended Asbury, now DePauw, University, entering the Law School of the University of Michigan, at Ann Arbor, in 1879, from which institution he graduated in 1881. He then located at Kokomo, where he was admitted to the bar, and where he has since resided. In 1882 he was elected Prosecuting Attorney for the Circuit Court, comprising Tipton and Howard Counties. In 1884 he was elected City Attorney for Kokomo, and was re-elected six times, resigning this position in 1901. He represented his district for six years on the Republican State Central Committee, serving as Vice-Chairman of the Committee in the campaign of 1892 . He was a delegate to the Republican National Convention at Philadelphia in 1900, representing the state as a member of the Committee on Credentials. Mr. Shirley has figured in the counsels of local, state and national politics since he became a voter. As a lawyer he has been associated in much of the important litigation in his own county, and in many important cases elsewhere in the state. In the course of his practice he has argued numerous cases in the Supreme Court of the State, and in the Federal Courts of this and other states, as well as in the Supreme Court of the United States.

Mr. Shirley represented the Ninth Congressional District on the Commission and was Chairman of the Committees on Literature and Fine Arts and Woman's Work. The art and literature of the state were appropriately represented in the Indiana Building, while Woman's Work was exhibited in the Manufacturers and Varied Industries Buildings. Detailed reports of these exhibits will be found elsewhere in this publication.

Mr. Shirley was married January 14, 1885, to Miss Blanche Klum of Kokomo. Their daughter Mary, the only child of the marriage, is just out of school.

Mrs. Shirley was hostess of the Indiana Building from October 20 to 30, and was assisted by Mrs. Wilbur J. McElwain. 


\section{Fremont Goodwine}

FREMONT Goodwine is a farmer and resides at Williamsport, Warren County. Mr. Goodwine was born near West Lebanon, Indiana, May 22, 1857, and received his education in Purdue University. He was for six years superintendent of the city schools at West Lebanon. He was elected County Superintendent of Warren County in 1887, and was re-elected in 1889 and 1891. Mr. Goodwine was elected by the Republicans to the State Senate in 1896 and represented Fountain and Warren Counties in the Sixtieth General Assembly and the Counties of Fountain, Warren and Benton in the Sixty-first General Assembly. He was re-elected and represented the same counties in the Sixty-second and Sixty-third General Assemblies, and for the third term was elected to serve in the Senate in the Sixty-fourth and Sixty-fifth General Assemblies. He was four times appointed by the Governor as a member of the Legislative Committee to visit the State Institutions and has been a member of the Board of Trustees of the Central Hospital for Insane. He still resides at Williamsport where he has banking, mercantile and agricultural interests.

Mr. Goodwine was appointed a member of the Commission from the Tenth Congressional District, and was Chairman of the Committee on Education, to which he gave much time, energy and careful study. It is only fair to $\mathrm{Mr}$. Goodwine and his committee to call attention to the detailed report of the educational exhibit, which was conceded to be the best in the Palace of Education.

- Mr. Goodwine was also a member of the Executive and Auditing Committees, and the Committee on Agriculture, Horticulture and Live Stock. Wolcott.

Mrs. Goodwine was hostess of the Indiana Building from October 10 to 20, and was assisted by Mrs. Eben H. 


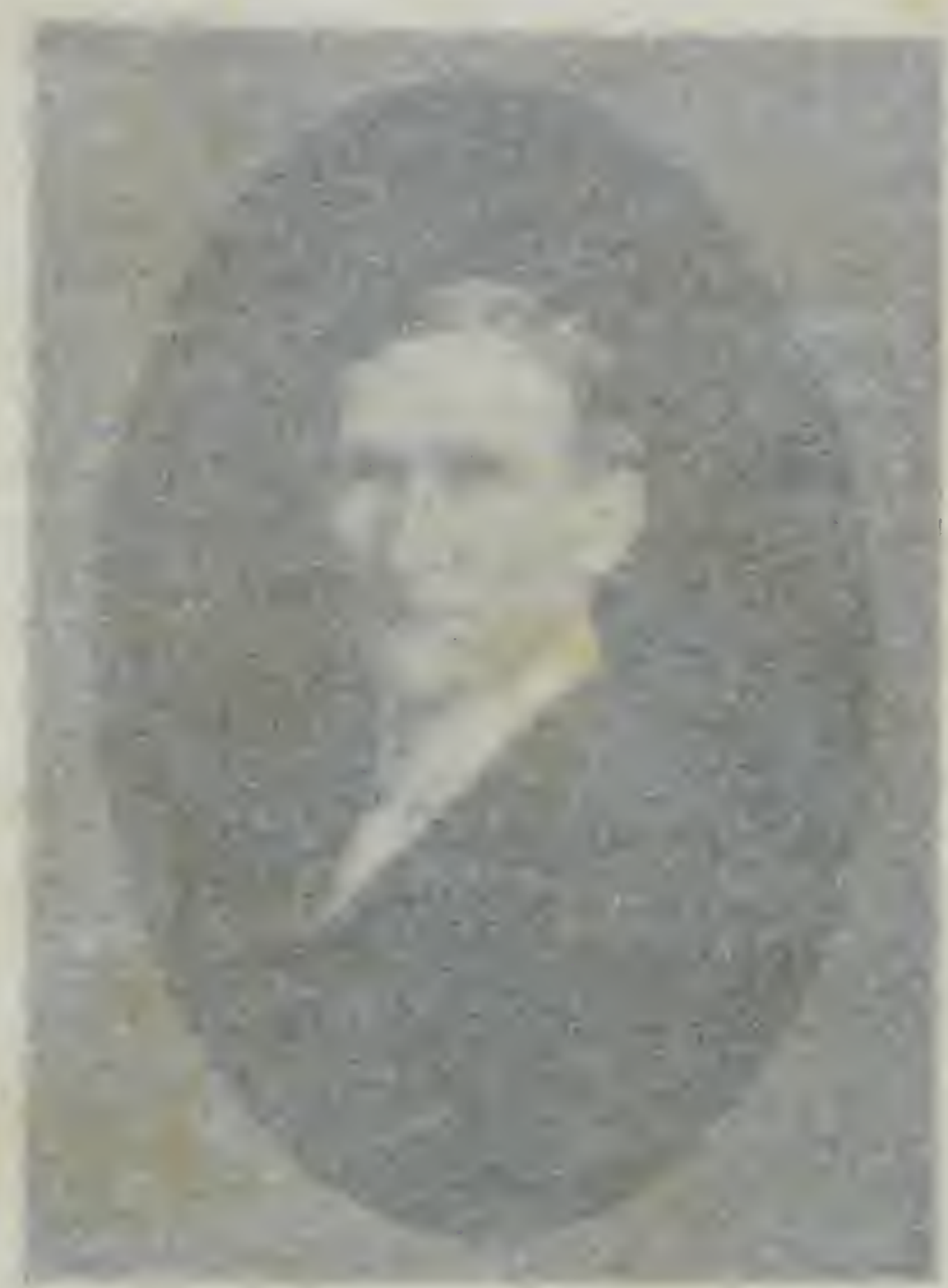

FREMONT GOODWINE,

Commissioner from the Tenth District. 


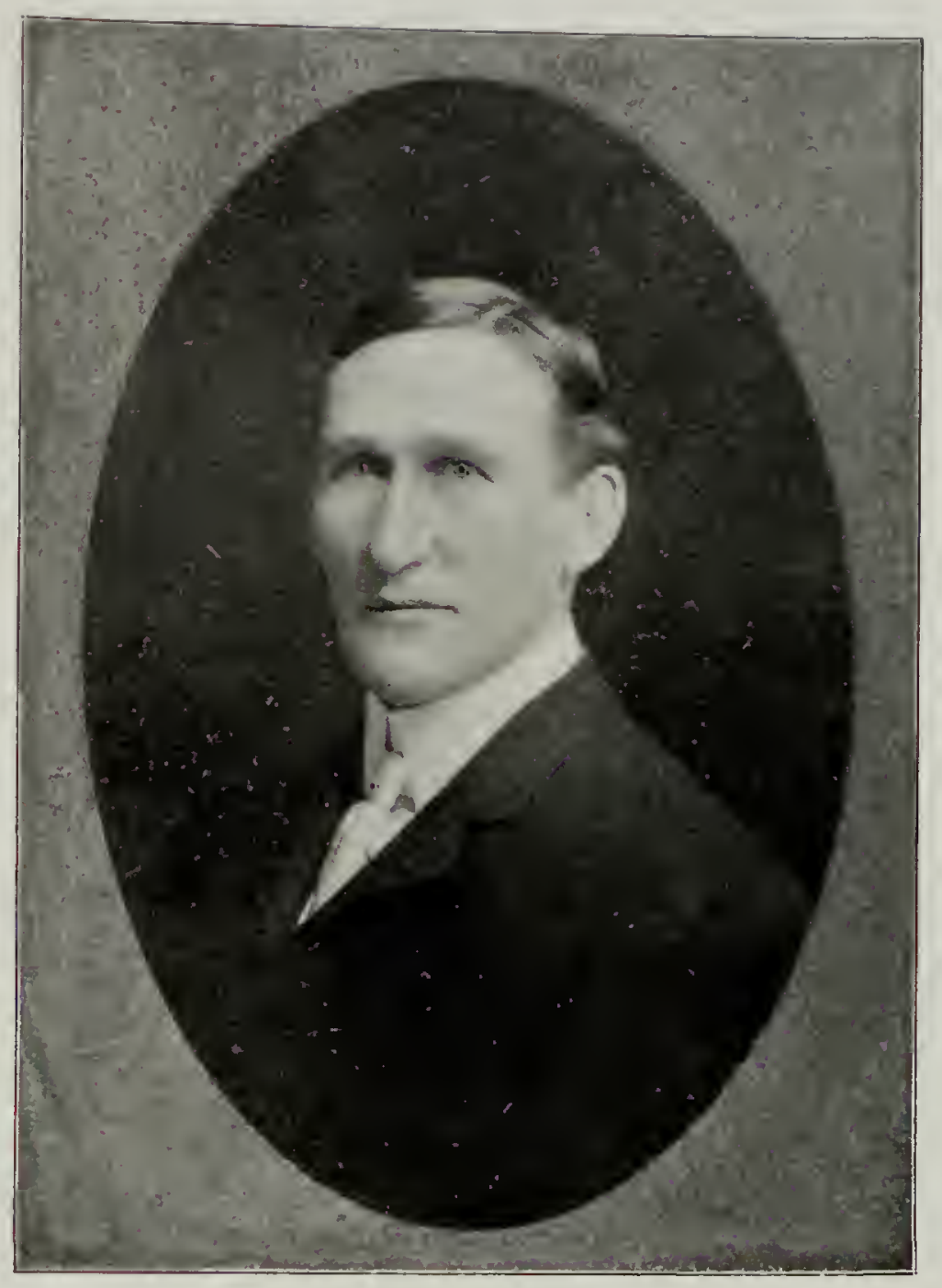




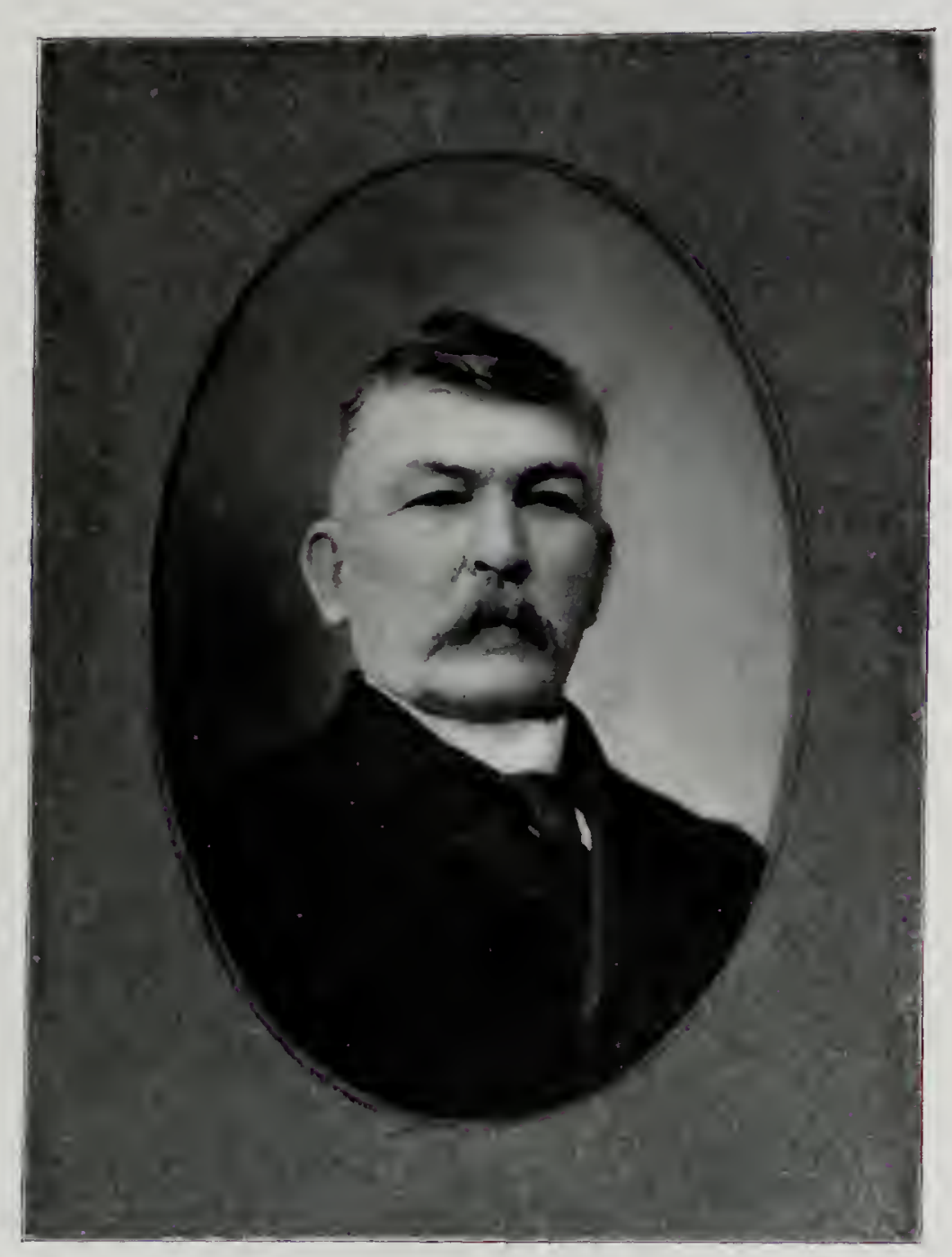




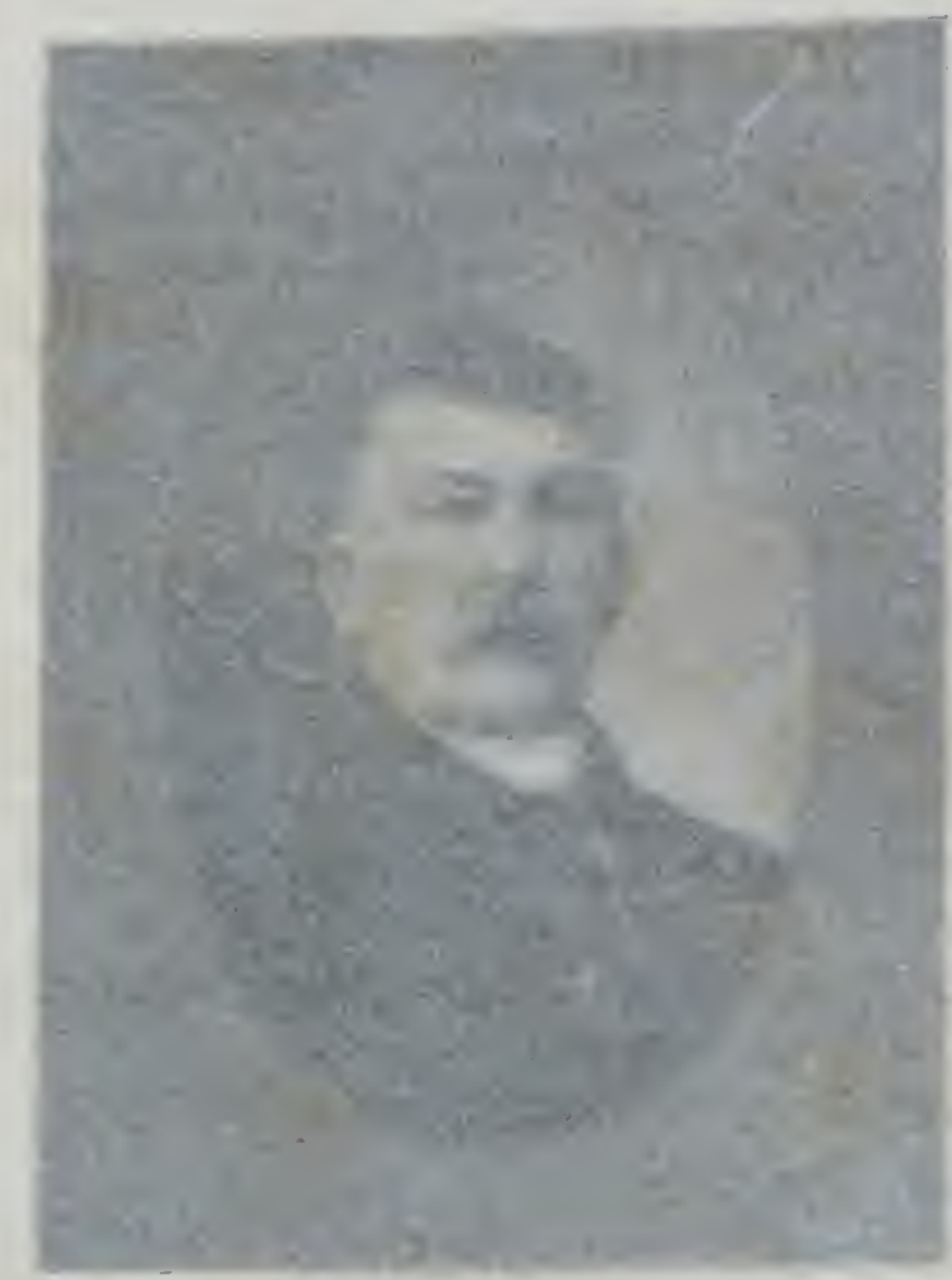

JOSEPH B. GRASS,

,Commissioner from the Eleventh District. 


\section{Joseph B. Grass}

Joseph B. Grass, of Huntington, represented the Eleventh Congressional District on the Commission. He was born on his father's farm, twelve miles from Niagara Falls, on the Canadian side, July 23, 1844 . He entered the railroad service when he was twenty-seven years old, and was engineer of a train over the Grand Trunk Railroad of Canada for ten years. He moved to Huntington, Indiana, twenty-two years ago and is now engaged in running the engine over the Erie Railroad that carries the Wells-Fargo express train from Huntington, Indiana, to Chicago, I11. Mr. Grass is one of the few engineers who has run an engine for over thirty years without an accident. This, it is said, is due to his good judgment, his careful consideration of his responsibility, and his appreciation of the value of human life.

Mr. Grass while being a practical railroad man, has give some attention to agricultural pursuits, in which he takes great pride, and has been very successful, owning at the present time a very fine farm near his home city.

Mr. Grass was Chairman of the Committee on Transportation, and his services as such were of value. He was for months in communication with the manufacturing concerns in this line in the state, giving every possible encouragement to those who were desirous of making an exhibit.

Mr. Grass was also a member of the Committees on Forestry and Machinery. He was a working, active member of the Commission and was always present at the business meetings.

Mrs. Grass served as hostess of the Indiana Building from August 1 to 10, and was assisted by her daughter, Mrs. Karl F. Parry, of Huntington, Indiana. 


\section{Stephen B. Fleming}

Stephen B. Fleming is a resident of Fort Wayne, Indiana. He was elected by the Democrats to the State Senate in 1900, and served through the Sixty-second and Sixty-third Sessions of that body, representing Adams and Allen Counties. He was one of the strong men of his party, being a member of many of the important committees and the leader of his party in the last session of his service. Mr. Fleming was urged to accept renomination but declined on account of the demands of large business affairs. He was for four years Democratic District Chairman of the Twelfth Indiana District.

Mr. Fleming was born on the 20th day of November, 1871. After receiving his education, he engaged in manufacturing in which he has been very successful. He is largely interested in box board and paper manufacturing, and is at the present time Secretary and General Manager of the United Box Board \& Paper Co., with headquarters in New York City. He is Secretary of the Fort Wayne and Wabash Valley Traction Co., and also Secretary of the Berghoff Brewing Company. He is one of the most successful and best known young men in the state. He is largely interested in electric railways and window glass business.

Mr. Fleming was Chairman of the Committee on Electrical Appliances, to which he gave valuable service. He was also a member of the Committees on Transportation, Machinery, and Literature and Fine Arts, to all of which he gave time, and contributed to their success.

Mrs. Fleming was hostess of the Indiana Building from November 10 to 20, and was assisted by Mrs. Frederick A. Joss, of Indianapolis. 


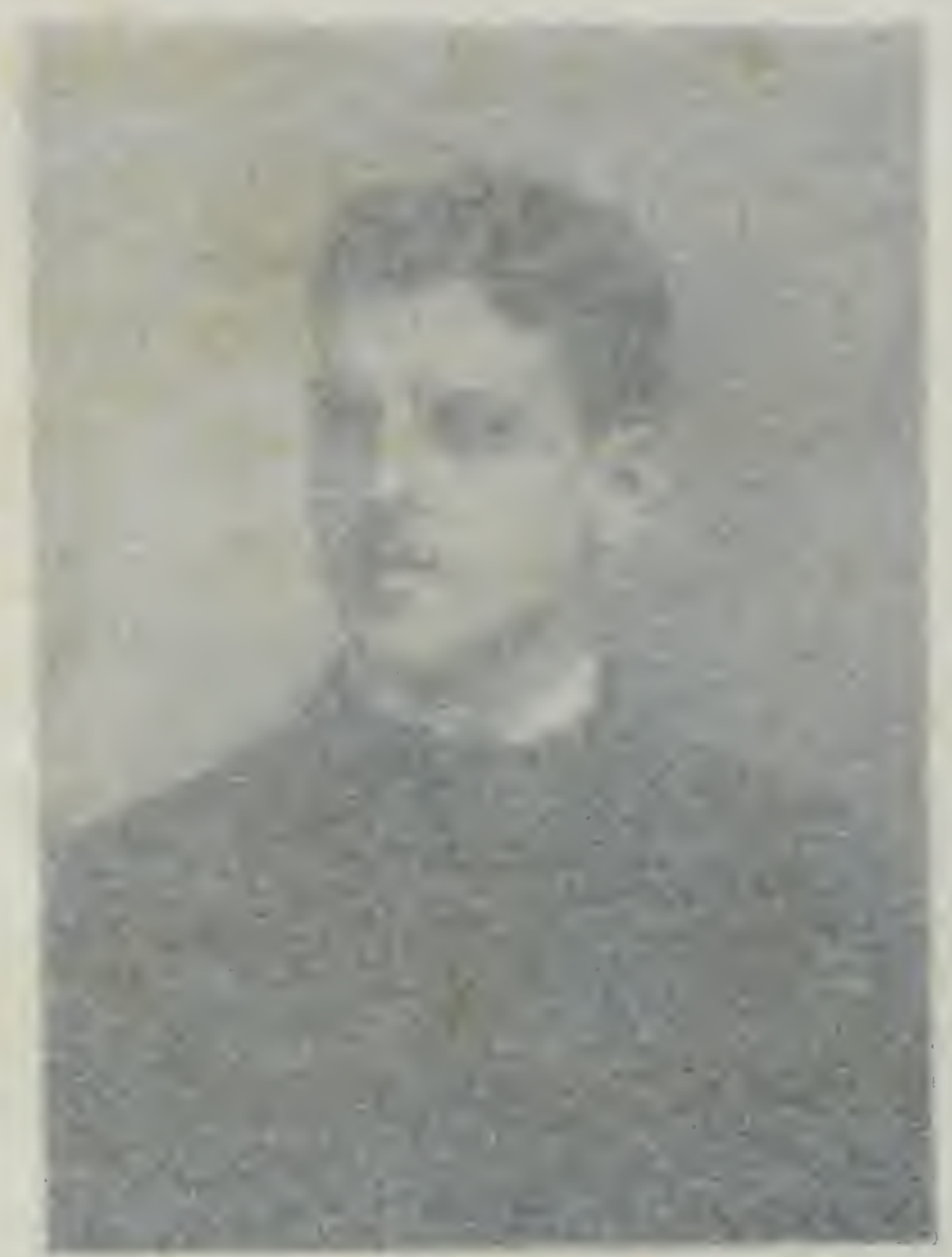

STEPHEN B. FLEMING,

Commissioner from the Twelfth District. 


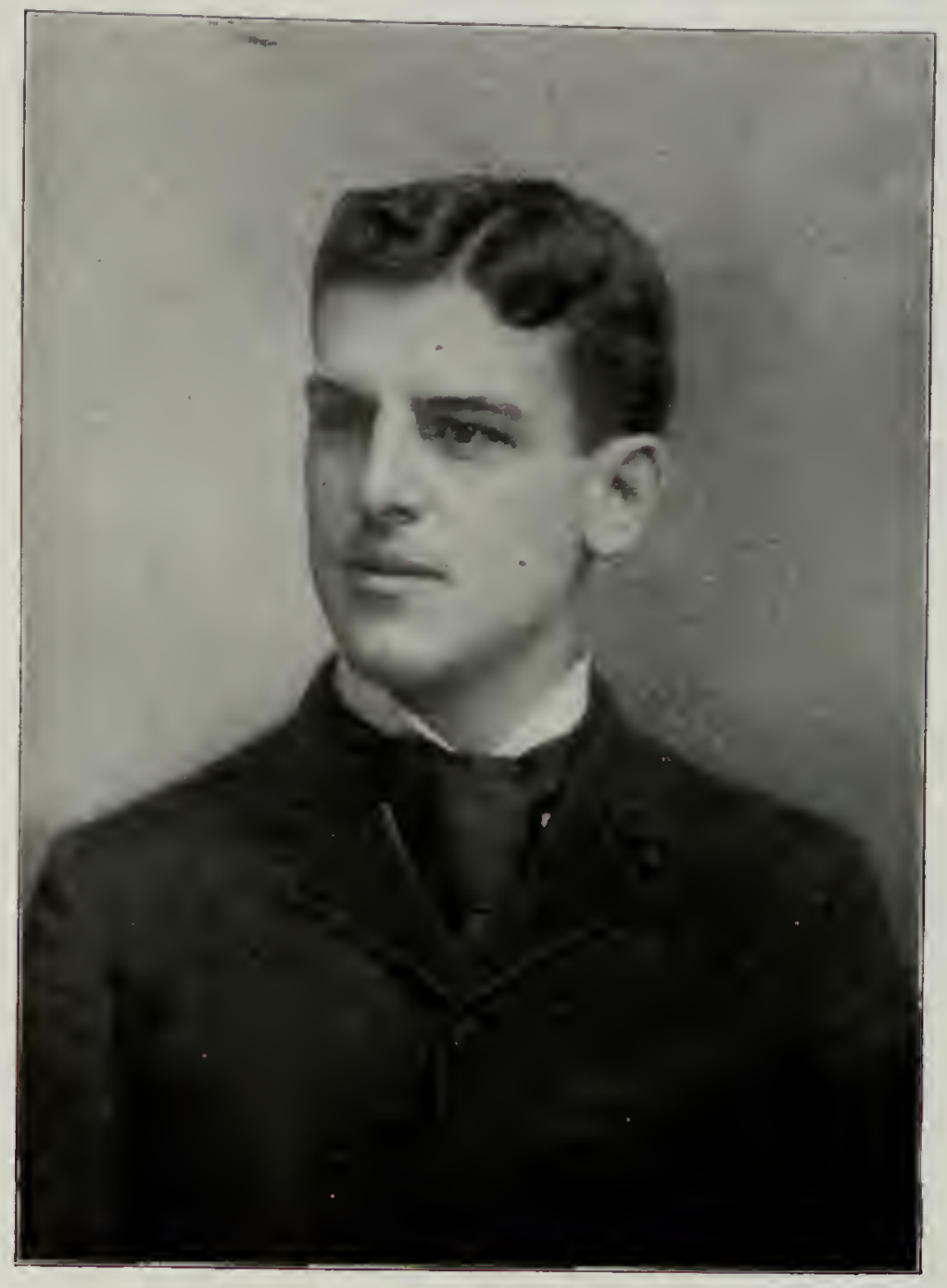





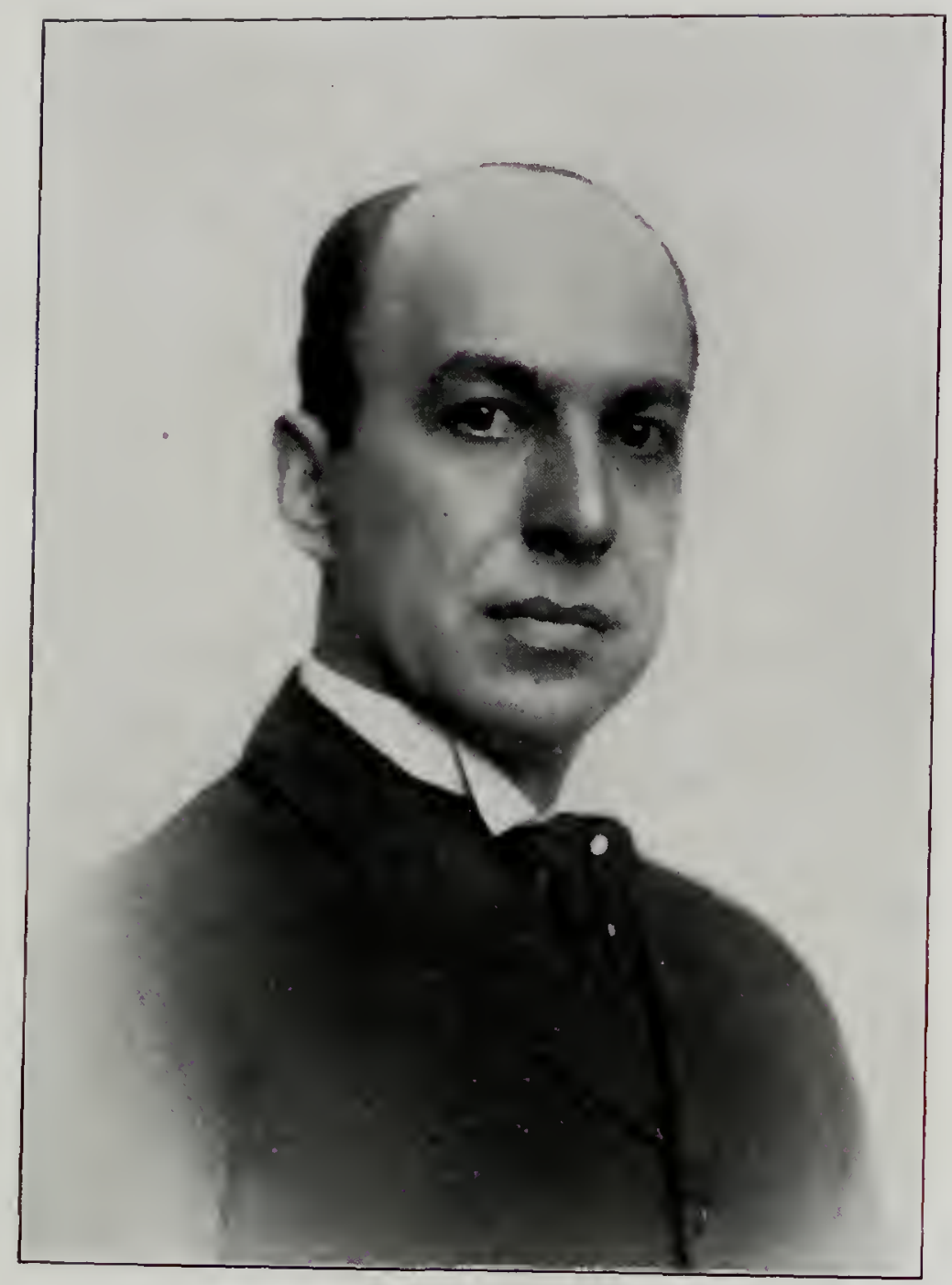




\section{Melville W. Mix}

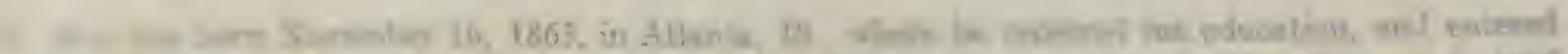

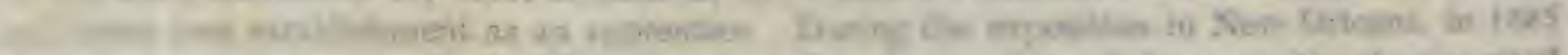

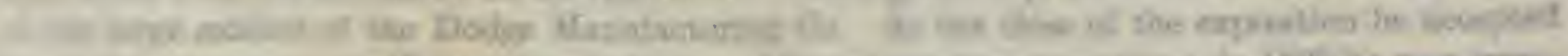

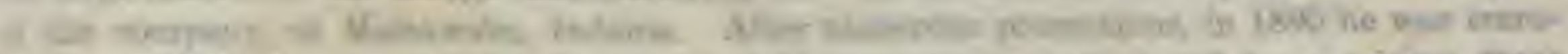

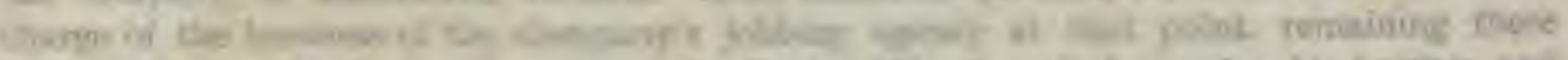

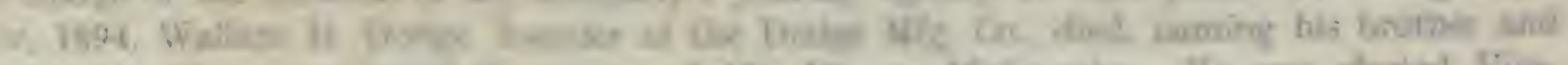

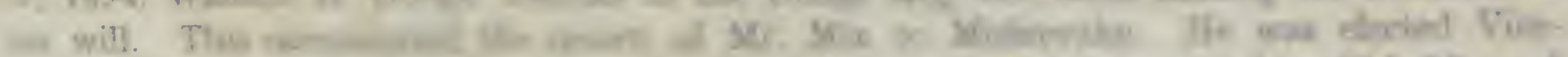

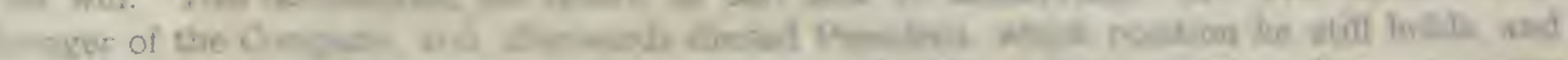

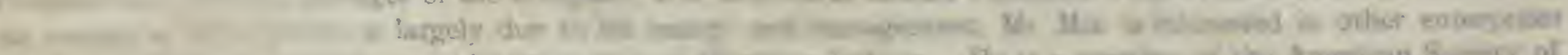

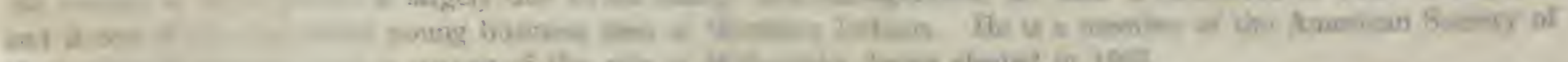

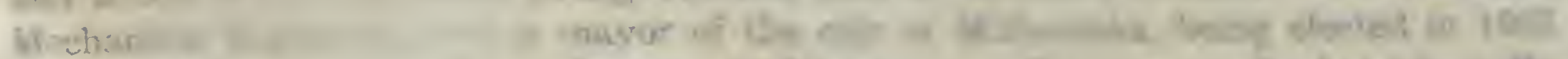

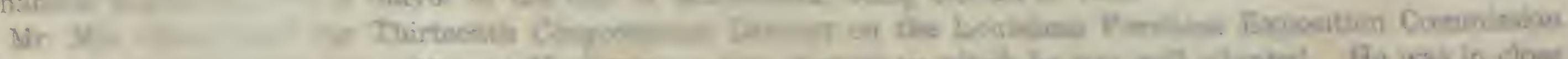

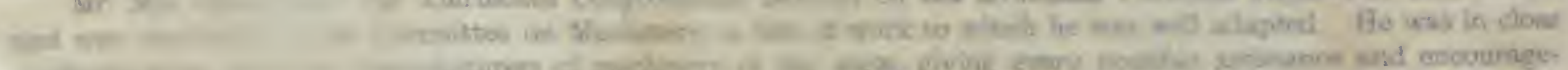

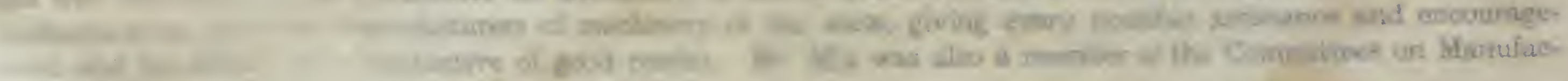

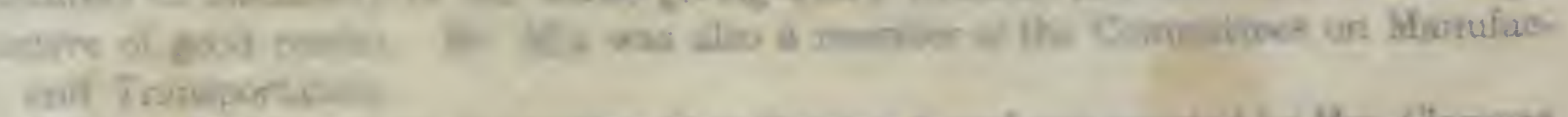

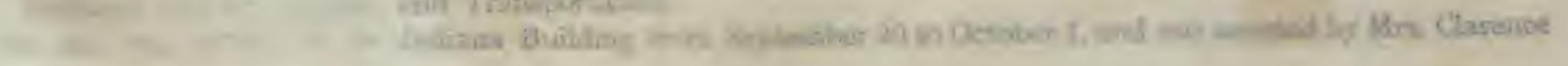

,XIM . W BJIJIVIGM

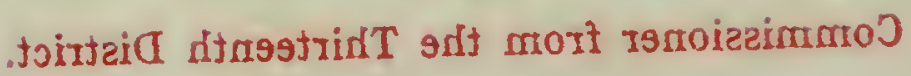

a 


\section{Melville W. Mix}

Melville W. Mix was born November 16, 1865, in Atlanta, I11., where he received his education, and entered his father's tin shop and sheet iron establishment as an apprentice. During the exposition in New Orleans, in 1885 Mr. Mix had charge of the large exhibit of the Dodge Manufacturing Co. At the close of the exposition he accepted a position in the office of the company, at Mishawaka, Indiana. After numerous promotions, in 1890 he was transferred to Chicago to take charge of the business of the Company's jobbing agency at that point, remaining there four years. In September, 1894, Wallace H. Dodge, founder of the Dodge Mfg. Co., died, naming his brother and Mr. Mix as executors of his will. This necessitated the return of Mr. Mix to Mishawaka. He was elected VicePresident and General Manager of the Company, and afterwards elected President, which position he still holds, and the success of this concern is largely due to his energy and management. Mr. Mix is interested in other enterprises and is one of the successful young business men of Northern Indiana. He is a member of the American Society of Mechanical Engineers, and is mayor of the city of Mishawaka, being elected in 1902.

Mr. Mix represented the Thirteenth Congressional District on the Louisiana Purchase Exposition Commission and was chairman of the Committee on Machinery, a line of work to which he was well adapted. He was in close communication with the manufacturers of machinery of the state, giving every possible assistance and encouragement, and his efforts were productive of good results. Mr. Mix was also a member of the Committees on Manufactures, Publicity and Promotion, and Transportation.

Mrs. Mix was hostess of the Indiana Building from September 20 to October 1, and was assisted by Mrs. Clarence M. Kenyon. 


\section{Personnel of the Commission}

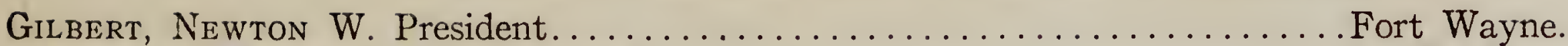

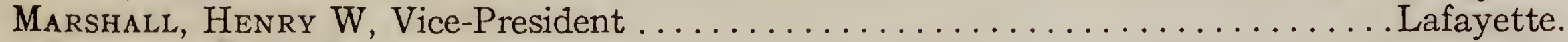

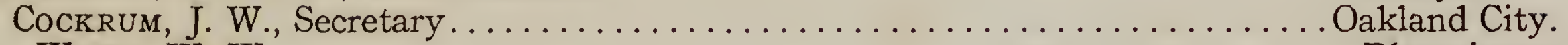

Wicks, W. W.

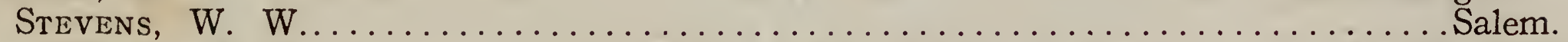

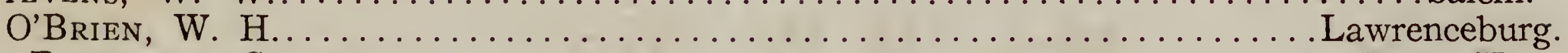

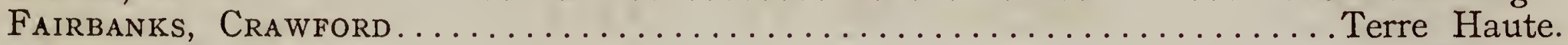

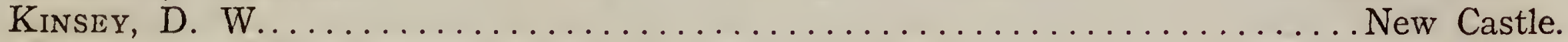

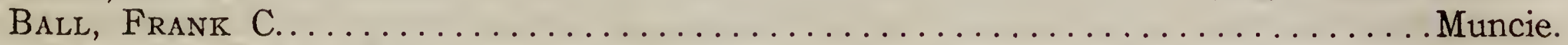

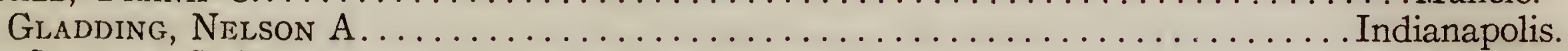

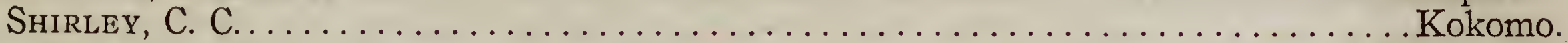

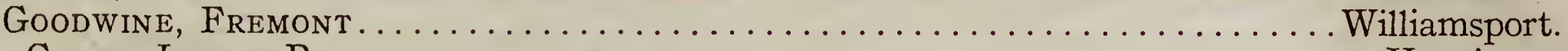

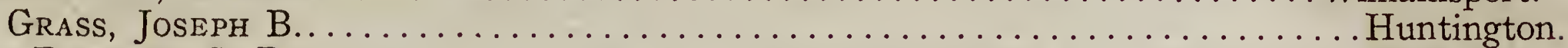

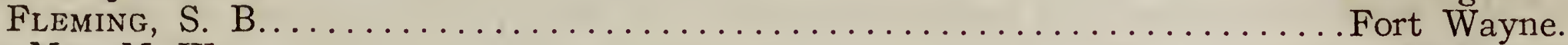

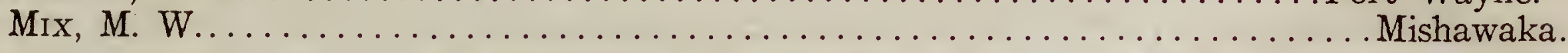

STANDING COMMITTEES.

Executive Committee.-Fairbanks, Gladding, Goodwine, Shirley, Wicks.

Manufactures.-Gladding, Mix, Ball.

Agriculture, Horticulture, and Live Stock.-Stevens, Goodwine, O'Brien.

Building Stone.--Wicks, Kinsey, Grass.

Forestry.-Gladding, Grass, Ball.

Mines and Mineral Products.-O'Brien, Fairbanks, Stevens.

Education.-Goodwine, Kinsey, Shirley.

Publicity and Promotion.-Kinsey, Shirley, Mix.

Woman's Work.-Shirley, Wicks, Ball.

Transportation.-Grass, Wicks, Ball.

Electrical Appliances.-Fleming, Stevens, Fairbanks.

Machinery.-Mix, Fleming, Grass.

Literature and Fine Arts.-Shirley, Fleming, Wicks.

State Building.-Ball, Kinsey, O'Brien.

Auditing Committee.-Goodwine, Gladding, O'Brien.

The Committee appointed by the Governor in September, 1902, to select a site for the Indiana Building was as follows:

Gilbert, Nkwton W., Lieutenant Governor.

Fleming, Stephen B., Senator.

Stechan, Hon. Otto,

SLACK, Hon. L. E. 


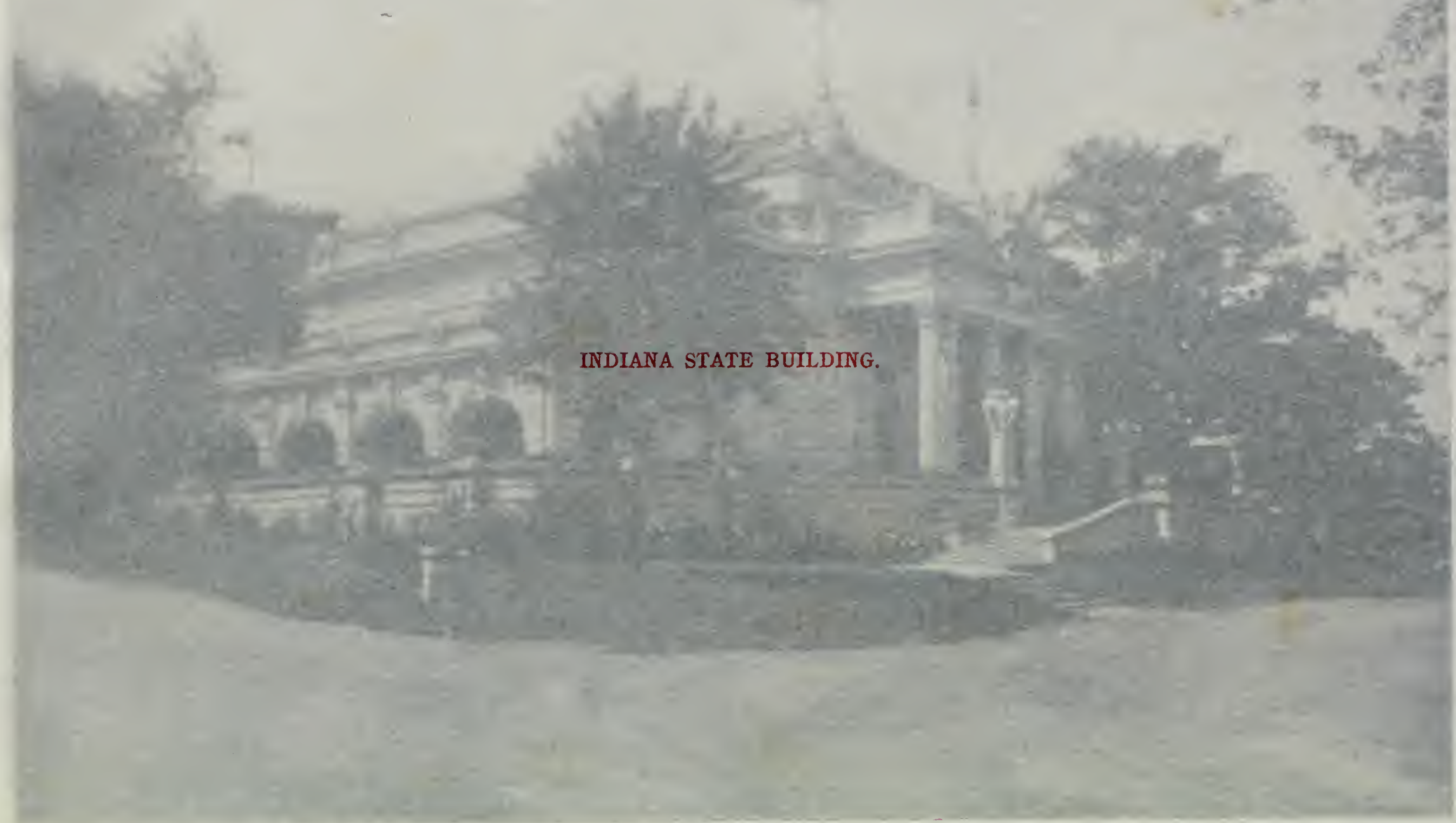




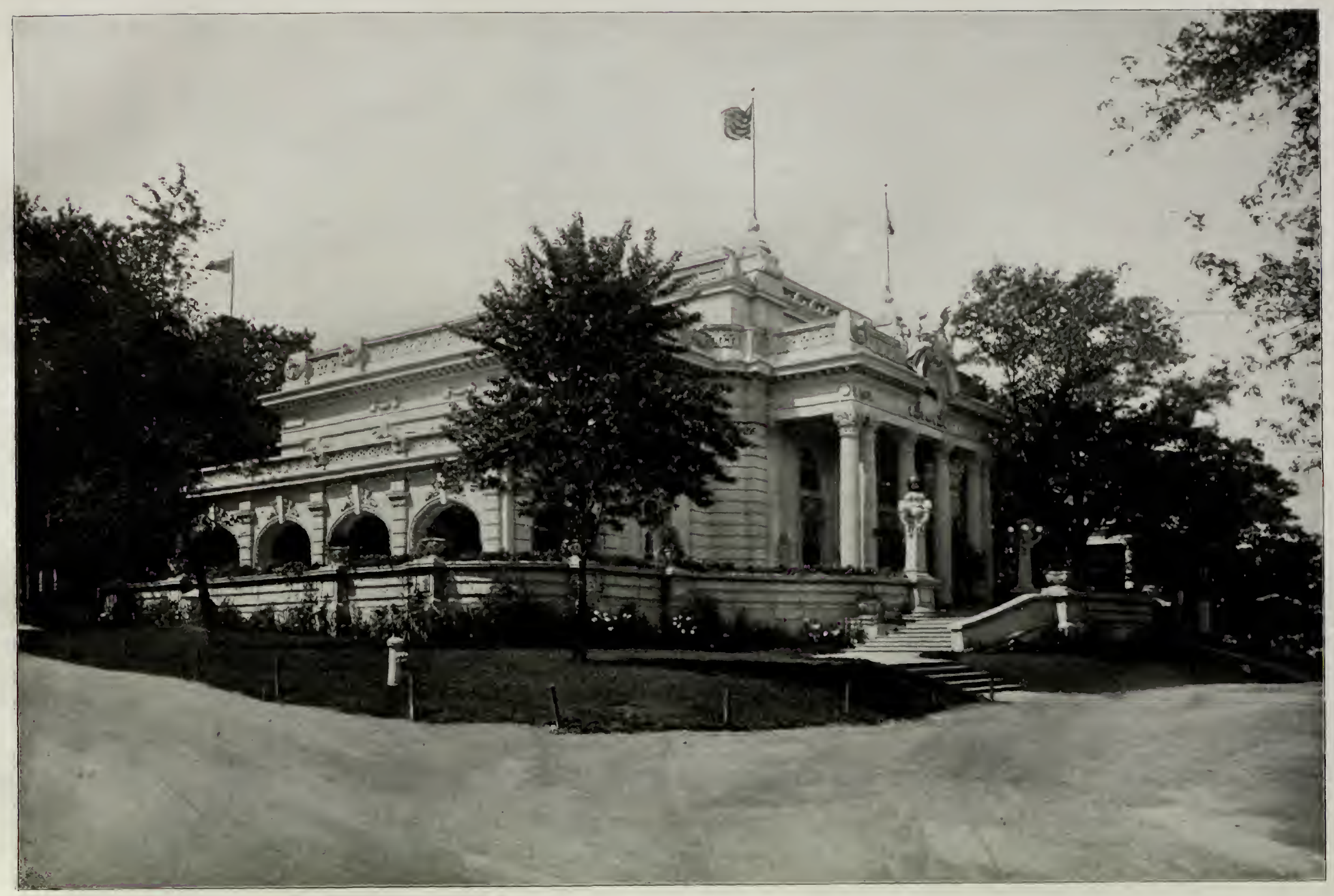




\section{Indiana Building}

We present a view of the east elevation of the Indiana Building at the St. Louis Exposition, which represents an achievement of Indiana architects and builders. The throngs of people who visited the building daily did not hesitate to proclaim their appreciation and declare the structure superb in every detail. Situated on a delightful elevation, surrounded by splendid forest trees, it was easily accessible from the state's entrance gate, and was visited by more people than any other state building. A conservative estimate of the total number of people who visited the Indiana Building is 2,100,000, while the register showed the daily average of Indiana visitors to be about 800 . People of every civilized nation visited the building and spoke words of commendation of the superior architecture, harmonious decorations and Hoosier hospitality which characterized it.

The Indiana Building was designed as a modern clubhouse by Wing \& Mahurin, Ft. Wayne, Indiana, and constructed by Caldwell \& Drake, Columbus, Indiana; and the literature and art of the state were made decorative features of the interior. The exterior combined French Renaissance and Colonial architecture. Surrounded by spacious porticos, the balustrades of which were surmounted by beautiful flowers, the very atmosphere suggested rest, comfort and hospitality. A large reception room from the main entrance was flanked by smaller parlors designated as gentlemen's and ladies' reception rooms. A broad spacious staircase led to a beautiful music room on the first landing, where were hung the works of the leading artists of Indiana. This room was furnished with two grand pianos of Indiana manufacture, and furniture of Louis XIV. style. Handsome oriental rugs covered the floor. A dome of tasteful art glass, a product of Indiana skill, was supported by Corinthian columns. On the second floor there was a large reading room where state newspapers and current periodicals were kept on file. At one end was the Governor's reception room; at the other the Commissioners' reception room. The latter contained a complete collection of the best Indiana literature. In this room there were also displayed original manuscripts and illustrations for books by Indiana authors.

The walls throughout the building were beautifully decorated with paintings and drawings, some of which represented Hoosier scenes and characters.

The Indiana Building through its luxurious and quiet furnishings, its artistic decorations and beautiful pictures, impressed the visitor with the culture of the state, and created an atmosphere of rest and comfort.

Special features of this commodious building were the check room, post office, rest rooms, offices, and a delightful lunch room, with Dutch furniture, where visitors checked their lunches free of charge, and returned to eat them at their pleasure. Indiana was the only state that provided this convenience and comfort. 


\section{Hostesses}

At a meeting of the Commission in May, it was decided that the wives of the Commissioners, or such other ladies as should be designated by them, should serve as hostesses of the Indiana Building from time to time during the Exposition. The allotment of time for each Commissioner and his wife to serve as host and hostess of the building was ten days It is due the ladies who served in this capacity without compensation, to say, that to them belongs a goodly part of the credit for bringing Indiana into such favorable notice. These ladies were always on hand to greet and accord to visitors that Hoosier welcome which has made the state famous. Each hostess and her assistant, with the help of the Commission, gave one or more social entertainments, and there was no one feature that added more to the success of the enterprise.

The following are those who served as hostesses, and their assistants:

Mrs. David W. Kinsey, New Castle, June 10 to 20; assisted by Mrs. L. A. Jennings, New Castle.

Miss Susan Ball, Terre Haute, June 20 to 30; assisted by Mrs. A. H. Donham, Terre Haute.

Mrs. James W. Cockrum, Oakland City, July 1 to 10; assisted by Mrs. Ella Wheatley, Oakland City.

Mrs. Nelson A. Gladding, Indianapolis, July 10 to 20; assisted by Mrs. A. D. Gates, Indianapolis.

Mrs. Joseph B. Grass, Huntington, August 1 to 10; assisted by Mrs. Karl F. Parry, Huntington.

Mrs. W. W. Stevens, Salem, August 20 to 30; assisted by Miss Warda Stevens, Salem.

Mrs. W. H. O'Brien, Lawrenceburg, September 1 to 10; assisted by Mrs. J. M. Bauer, Lawrenceburg.

Mrs W. W. Wicks, Bloomington, September 10 to 20; assisted by Mrs. G. W. Cunningham, Bloomington.

Mrs. M. W. Mix, Mishawaka, September 20 to 30; assisted by Mrs. Clarence M. Kenyon, Indianapolis.

Mrs. H. W. Marshall, Lafayette, October 1 to 10; assisted by Mrs. S. T. Murdock, Lafayette.

Mrs. Fremont Goodwine, Williamsport, October 10 to 20; assisted by Mrs. Eben H. Wolcott, Wolcott.

Mrs. C. C. Shirley, Kokomo, October 20 to 30; assisted by Mrs. W. J. McElwain, Kokomo.

Mrs. Frank C. Ball, Muncie, November 1 to 10; assisted by Mrs. Lucius Ball, Muncie.

Mrs. S. B. Fleming, Fort Wayne, November 10 to 20; assisted by Mrs. Frederick A. Joss, Indianapolis.

Mrs. O. N. Guldlin, Fort Wayne, November 20 to December 1. 


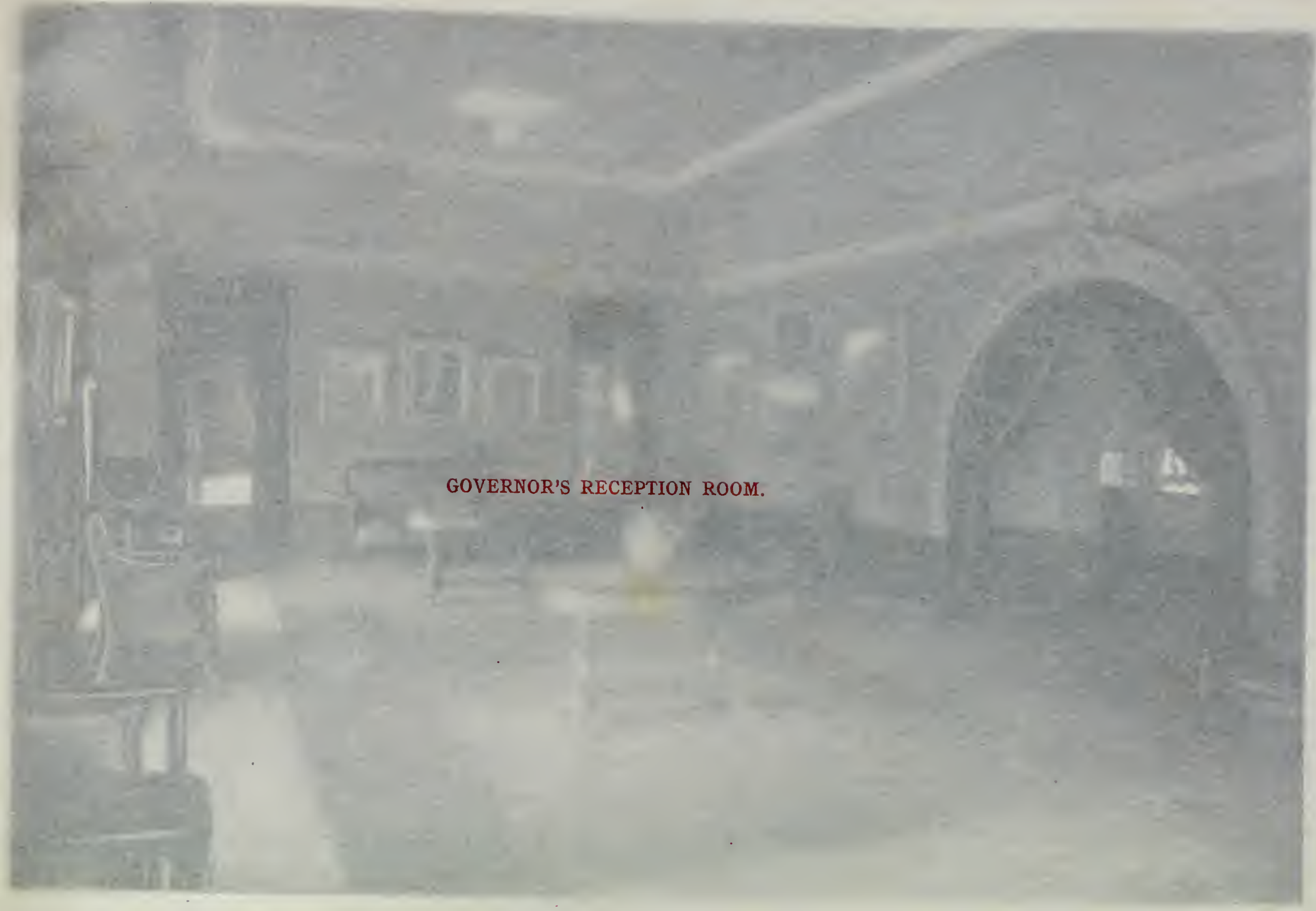




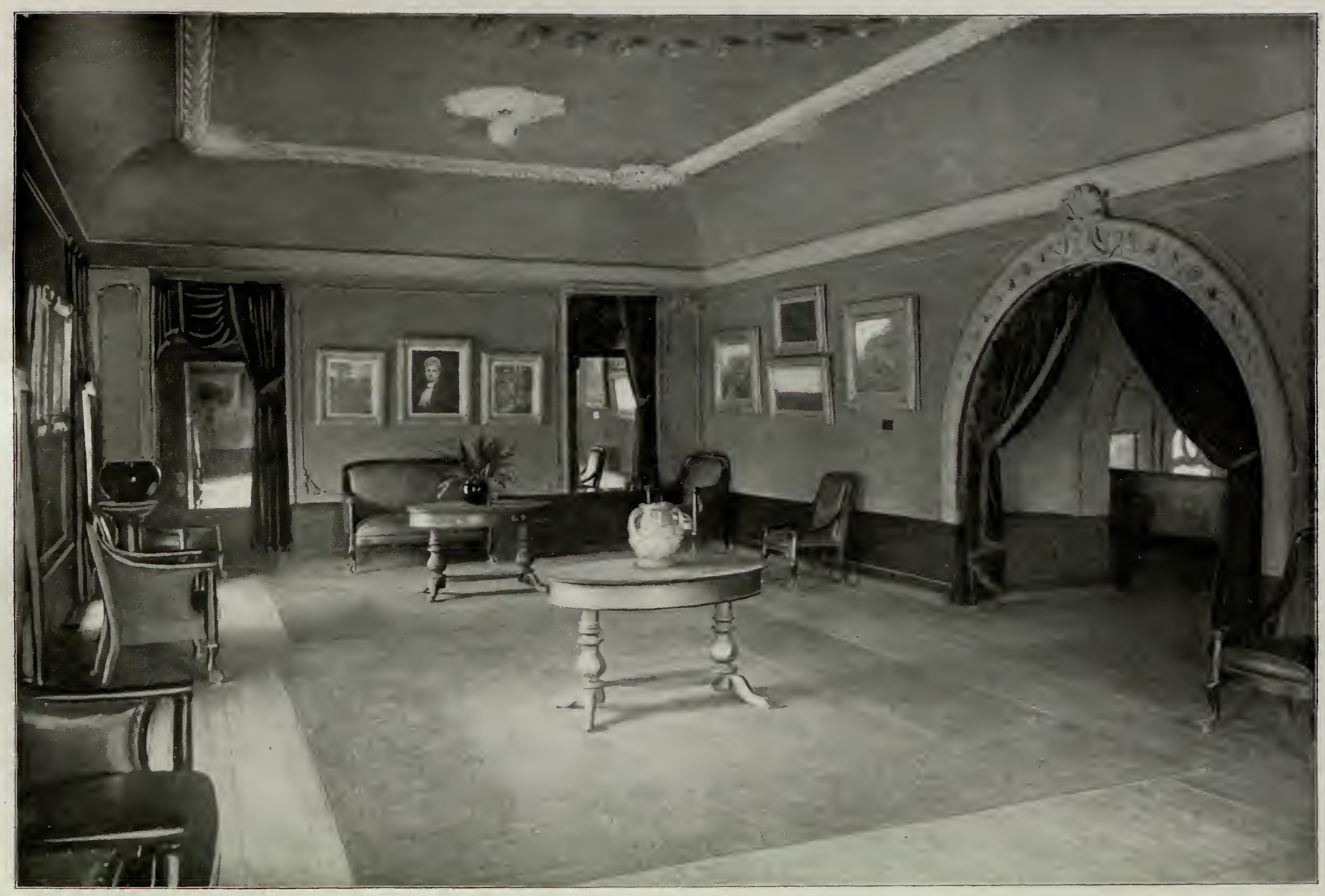





\section{Ceremonials and Entertainments}

The Governor's reception room was handsomely decorated with appropriate paintings and was used on almost every occasion of entertainment at the building. The following are the dates and occasions of some of the more important ceremonial and social events at the Indiana Building:

The first and one of the most important ceremonials under direction of the Indiana Commission, was the occasion of the dedication of the State Building, June 3.

Although the very inclement weather seriously interfered with this event, making it necessary to abandon the military parade for which elaborate preparations had been made, the building was crowded with peoplecitizens of the state and other invited guests-and the program rendered there was interesting throughout.

The Vice-President of the Commission presided over the ceremonies and the following program was carried out:

Prayer-Rev. W. D. Cole, Lafayette.

ORCHESTRAL MUSIC.

Report of Building Committee and delivery of building to the Commission-F. C. Ball, Chairman of Building Committee.

Address-Henry W. Marshall, Vice-President of the Commission, delivering keys to the building, to the Governor of the state.

Address-Governor Winfield T. Durbin, accepting building on behalf of the citizens of the state.

\section{MUSIC.}

Address-Hon. David R. Francis, President, Louisiana Purchase Exposition.

Address-Hon. Rolla Wells, Mayor of St. Louis.

\section{MUSIC.}

Address-Lieutenant Governor Newton W. Gilbert, President of the Commission.

At the conclusion of the program, Miss Alice Roosevelt visited the building and held an informal reception in the music room.

In the evening a reception was given in honor of Governor and Mrs. Winfield T. Durbin. For this occasion about two hundred prominent ladies of the State were requested to assist in the entertainment of the guests, and the presence of a large number of these contributed greatly to the brilliancy of the reception. The response to the invitations was very general, and this reception was the largest and most elaborate given during the period of the Exposition.

For the dedicatory ceremonies the building was most artistically decorated with three thousand rare American Beauty roses, creating a picture of most charming beauty, and producing an effect that was pleasing to all.

"Indiana Day," September 1, was one of the best attended and most successful military and social functions given by any state. The line of march was over four miles long. The parade was strictly military, forming at the 
Administration Building at 10:30 and proceeding to the Indiana Building by the following route: East to the Palace of Mines and Metallurgy and around this building, passing the U. S. Fisheries Building to Commonwealth avenue; south on Commonwealth avenue to Colonial avenue and west to the Indiana State Building.

The order of march was as follows:

Detachment of Jefferson Guards.

Adjutant General John R. Ward, Marshal and Staff.

Band, Philippine Scouts.

Battalion Philippine Scouts.

Battalion, U. S. Marines.

Band, Philippine Constabulary.

Batalion Philippine Constabulary.

Indianapolis News' Newsboys' Band.

Governor Durbin and President Francis, in carriage.

Governor's Staff in carriages.

Indiana World's Fair Commission, in carriages.

Packard Band, Fort Wayne.

National World's Fair Commission.

Indiana State Officers.

Philippine Officials. Philippine Board.

Citizens of Indiana, in carriages and on foot.

President Newton W. Gilbert, of the Commission, presided during the exercises, which were as follows:

Prayer by Rev. W. P. Dearing, President Oakland City College.

Song, "America," by audience accompanied by bands.

Address by President Gilbert.

Address of Welcome by President Francis.

Address by Governor Winfield T. Durbin.

Address by Hon. F. B. Posey, Evansville, Ind.

In the evening at eight o'clock, one of the most brilliant receptions of the season was given in honor of Governor and.Mrs. Durbin. 


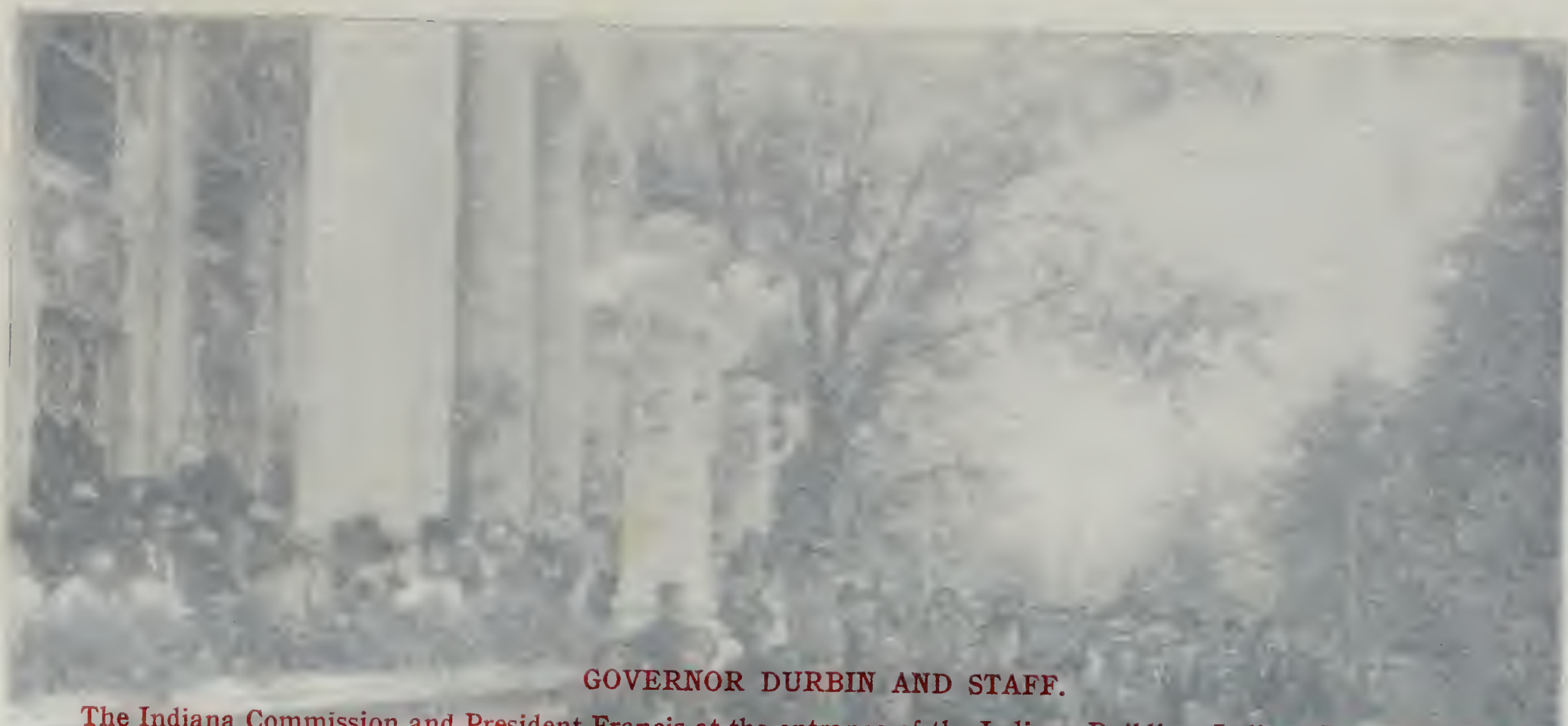

The Indiana Commission and President Francis at the entrance of the Indiana Building, Indiana Day, September 1.

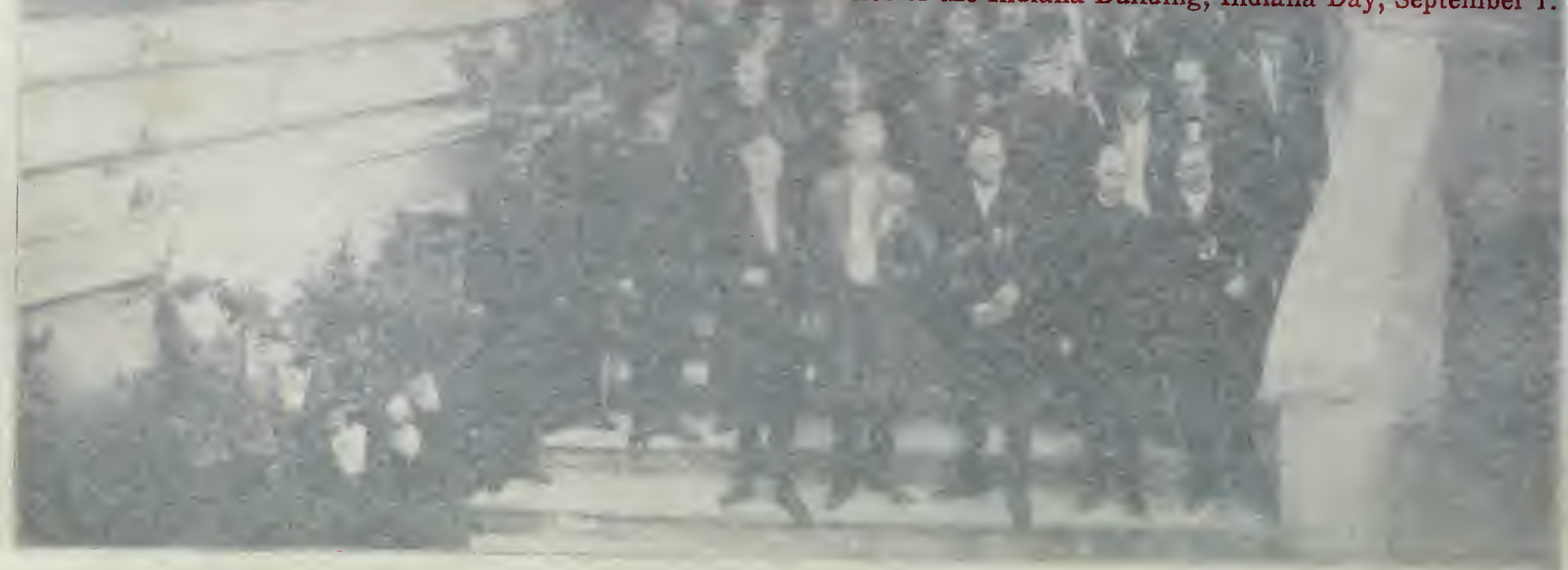




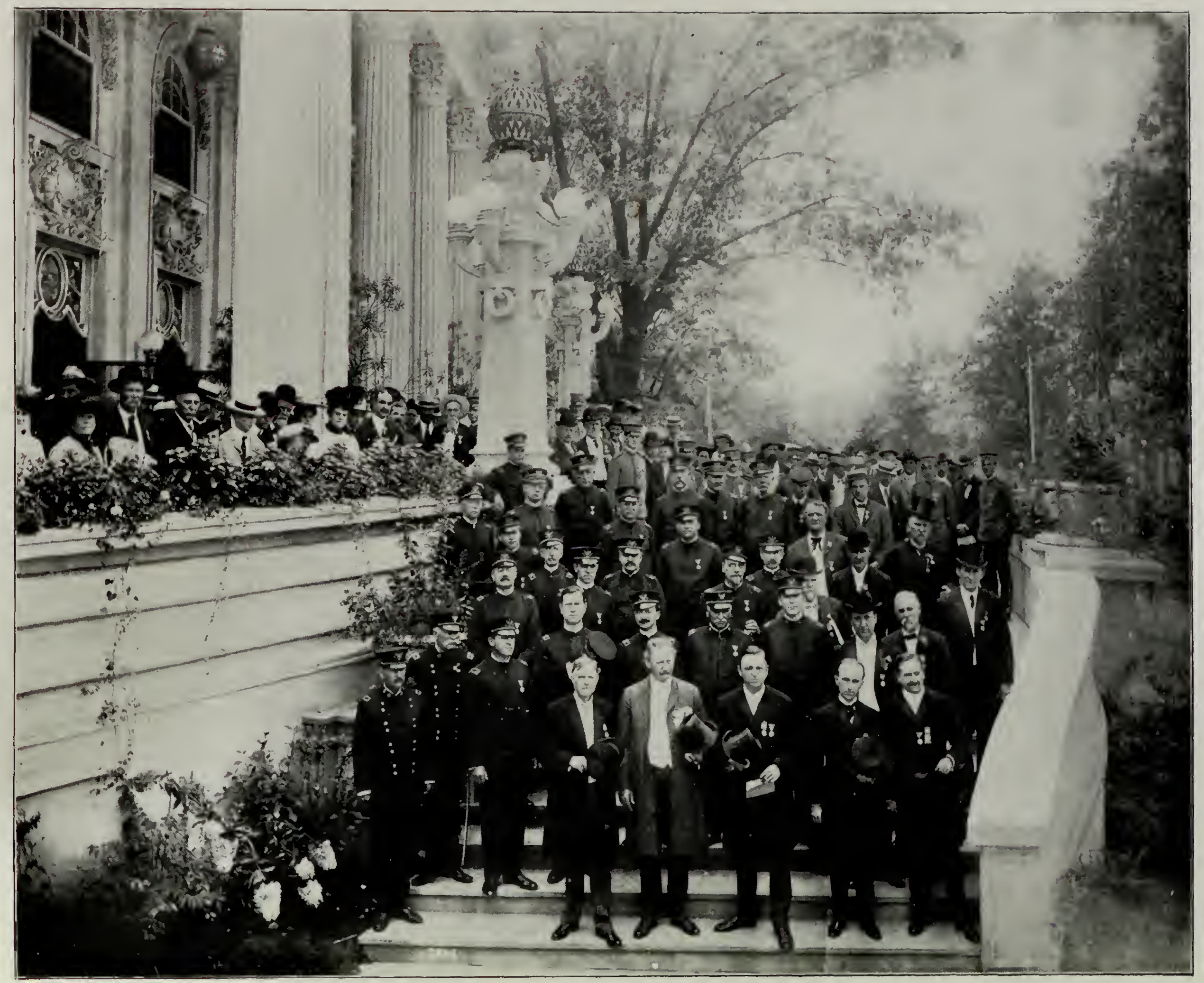


"Indianapolis Day" was another notable event for the Hoosiers. Many thousands of Indiana citizens attended the ceremonies. The program was as follows at the Indiana Building:

\section{$1: 00$ P. M.}

\section{Concert, Indianapolis Military Band.}

$1: 30$ P. M.

Introductory remarks, Councilman Albert E. Uhl, Chairman Council Indianapolis Day Committee, Presiding officer.

Address: President David R. Francis, Louisiana Purchase Exposition.

Address: Mayor Rolla G. Wells, St. Louis.

Air: "On the Banks of the Wabash," Indianapolis Military Band and visitors.

Address: Judge Jesse A. McDonald, St. Louis Circuit Court.

Address: Mayor John W. Holtzman, Indianapolis.

Address: Hilton U. Brown, Vice-President Indianapolis Commercial Club.

Poem: "Indianapolis," City Clerk W. M. Fogarty, Indianapolis.

Address: Hon. Henry W. Marshall, Lafayette, Indiana, Vice-President Indiana World's Fair Commission.

"Auld Lang Syne," Indianapolis Military Band.

$$
\text { 3:30 P. M. }
$$

Concert by Indianapolis Military Band and instrumental soloists.

\section{4:00 P. M.}

Song Recital, Miss Myrtle Irene Mitchell.

\section{$8: 30$ P. M.}

Reception and Ball at the Indiana Building.

The Reception Committee consisted of one hundred and fifty prominent Indianapolis citizens who were carried to the World's Fair City in a special train, with Nelson A. Gladding, Chairman of the Committee.

May $19 \therefore \ldots \ldots$. Reception in honor of members of the National Editorial Association.

June $10 \ldots \ldots \ldots$ "Indiana Press Day," reception in honor of Indiana Editors and their wives.

June $11 \ldots . .$. Reception and ball in honor of the Marion High School, Mrs. D. W. Kinsey, hostess, assisted by Mrs. L. A. Jennings.

June $29 \ldots . . .$. Reception in honor of Indiana Teachers attending the National Editorial Association, and also members of the Indiana County School Superintendents' Association. Miss Susan Ball, hostess, assisted by Mrs. L. A. Donham.

July $9 \ldots \ldots$...... Afternoon tea and reception, Mrs. J. W. Cockrum, hostess, assisted by Mrs. Ella T. Wheatley, to the hostesses of the State Buildings.

July $21 \ldots . . .$. Afternoon reception, Mrs. Nelson A. Gladding, hostess, assisted by Mrs. Arthur D. Gates, entertaining Exposition Officials, Foreign and State Commissioners and the hostesses of the State Buildings.

August 9........... Afternoon tea and reception, Mrs. Joseph B. Grass, hostess, assisted by Mrs. Karl F. Parry, entertaining the hostesses of the State Buildings.

August 28 ....... Automobile ride, Mrs. Warder W. Stevens, hostess, assisted by Miss Warda Stevens, entertaining the hostesses of the State Buildings. 
August $30 \ldots . . .$. Reception and ball, Mrs. Warder W. Stevens, hostess, assisted by Miss Warda Stevens, in honor of the members of the Kappa Kappa Gamma Fraternity.

September 9 .... Luncheon at the Glen Echo Country Club, Mrs. William H. O'Brien, hostess, assisted by Mrs. W. H. Bauer, to the hostesses of the State Buildings, the party using the private car of Mr. McCullough, Vice-President and General Manager of the St. Louis Street Car Company.

September 10-20 ... Informal afternoon receptions, Mrs. W. W. Wicks, hostess, assisted by Mrs. G. W. Cunningham.

September 19 .... Reception and ball in honor of the Culver Cadets, Mrs. W. W. Wicks, hostess, assisted by Mrs. G. W. Cunningham.

September 23 ..... Reception and ball, Mrs. Melville W. Mix, hostess, assisted by Mrs. Clarence M. Kenyon, in honor of Governor and Mrs. Winfield T. Durbin, and Mrs. W. H. Coleman, Member of the Board of Lady Managers.

September 28 ..... Song recital by Miss Myrtle Irene Mitchell, Mrs. Melville W. Mix, hostess, assisted by Mrs. Clarence M. Kenyon.

September $30 \ldots$... Reception and ball in honor of the press of the World's Fair and St. Louis.

October 5........Reception and ball, Mrs. Henry W. Marshall, hostess, assisted by Mrs. S. T. Murdock, in honor of Mayor and Mrs. John W. Holtzman.

October $12 \ldots . .$. Song recital and reception, Miss Myrtle Irene Mitchell, Mrs. Fremont Goodwine, hostess, assisted by Mrs. Eben H. Wolcott, entertaining the hostesses of the State Buildings.

October 19 ....... Reception, Mrs. Fremont Goodwine, hostess, assisted by Mrs. Eben H. Wolcott, in honor of Governor and Mrs. Brady, of Alaska, and the Indiana members of the American Library Association.

October $22 \ldots . .$. Reception and ball in honor of the Indiana University Football Team, Mrs. C. C. Shirley, hostess, and her daughter, Miss Mary Shirley.

October 25....... Reception and luncheon in honor of hostesses of the State Buildings, Mrs. C. C. Shirley, hostess, assisted by Mrs. W. J. McElwain.

November 1-10 ....Mrs. Frank C. Ball, hostess, assisted by Mrs. Lucius Ball, gave informal afternoon teas.

November 18 ..... Reception and ball, Mrs. Steven B. Fleming, hostess, assisted by Mrs. Frederick A. Joss, in honor of Governor-elect and Mrs. J. Frank Hanly.

November 20-30 ... Mrs. O. N. Guldlin, hostess, received informally, afternoons.

November 21 ..... Reception in honor of Vice-President-elect Charles W. Fairbanks.

November 27 ..... Illumination of entirc building and grounds in honor of the visit of President Roosevelt.

In addition to the more formal receptions and entertainments mentioned above, daily concerts were given by Miss Hazel Robinson and Miss Fanny Alexander, of Marion, and Miss Theodora Sturkow, the Russian pianist, gave daily piano recitals in the Indiana Building.

These concerts and recitals attracted thousands of visitors and were a feature that added to the popularity of the building. Many other informal receptions and entertainments of less importance were given by the Commissioners and their wives during the summer. 


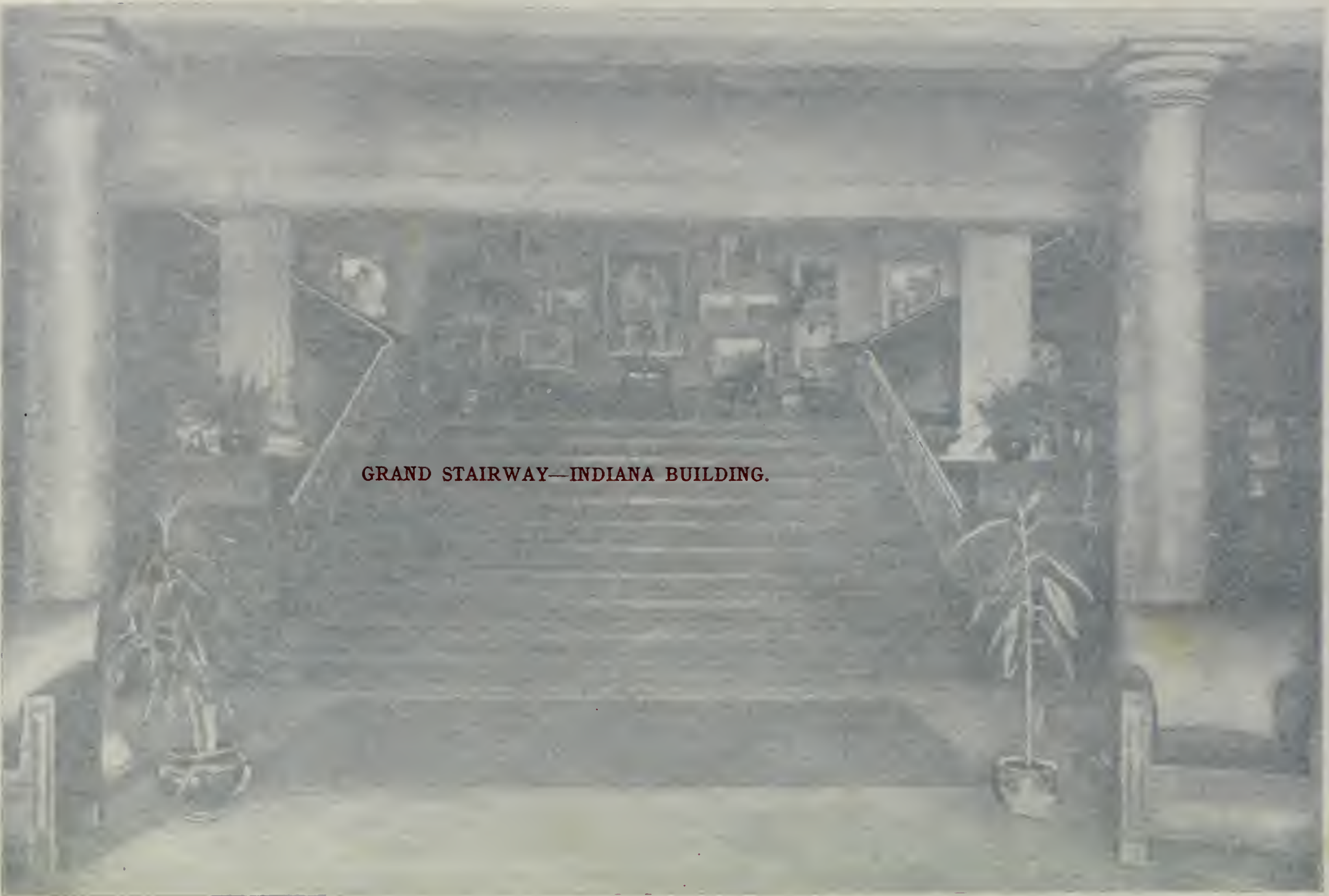




\section{Official Report of Indiana Commission}

The reader will observe that from this page to the addenda of this publication embodies the report of the Commission to the Governor. We call special attention to this report as it is a plain statement of facts based upon personal knowledge of the Commission concluded by a financial statement showing the disbursements of the entire transaction.

$$
\left.\begin{array}{c}
\text { Office of } \\
\text { The Louisiana Purchase Exposition Commission of Indiana, } \\
\text { Indianapolis, Indiana, January 6, 1905. }
\end{array}\right\}
$$

Honorable Winfield T. Durbin, Governor of the State of Indiana, Indianapolis, Indiana.

Sir:-The Louisiana Purchase Exposition Commission of Indiana has the honor to submit herewith a statement of all exhibits made by the State of Indiana and the citizens thereof, so far as the same have come to our knowledge or within our jurisdiction, together with the awards made on such exhibits, with a general statement of the transactions of the Commission from the time of its organization. There is appended an account of all receipts and disbursements, for which complete vouchers have been filed with the Auditor of State from time to time as the moneys were drawn. This report is in conformity with Chapter CCI of the Acts of 1903, found upon page 352, et seq.

Pursuant to instructions issued from your office at the time of the appointment of the Commission, the gentlemen composing the same, to-wit: Newton W. Gilbert, Fort Wayne; Henry. W. Marshall, Lafayette; James W. Cockrum, Oakland City; W. W. Wicks, Bloomington; W. W. Stevens, Salem; W. H. O'Brien, Lawrenceburg; Crawford Fairbanks, Terre Haute; D. W. Kinsey, New Castle; Nelson A. Gladding, Indianapolis; Frank C. Ball, Muncie; C. C. Shirley, Kokomo; Fremont Goodwine, Williamsport; Joseph B. Grass, Huntington; S. B. Fleming, Fort Wayne; and M. W. Mix, Mishawaka, met at the State House, at Indianapolis, Indiana, on Wednesday, April 22, 1903, and proceeded to organize by the election of Newton W. Gilbert, President; Henry W. Marshall, Vice-President; and James W. Cockrum, Secretary. A committee was also appointed to prepare by-laws and regulations for the government of the Commission. Prior to adjournment, Acil C. Alexander, of Marion, Indiana, was elected Assistant Secretary. The Commission had little to guide it in the matter of methods to be pursued in providing for proper representation of the state at the Louisiana Purchase Exposition. Previous Commissions of like character in our state had left no record of their proceedings. We were compelled for some time to proceed with great care and caution to the end that the varied interests of Indiana should be adequately represented without giving undue prominence to any one resource or interest above another. It was decided that the next meeting of the Commission should be held at the World's Fair grounds, at St. Louis, Mo., with a view not only of selecting a site for the Indiana State Building, but of acquainting ourselves as fully as possible with the general conditions prevailing. 
By the rules subsequently adopted, it was decided to have thirteen Standing Committees in addition to the Executive Committee. These Committees were as follows:

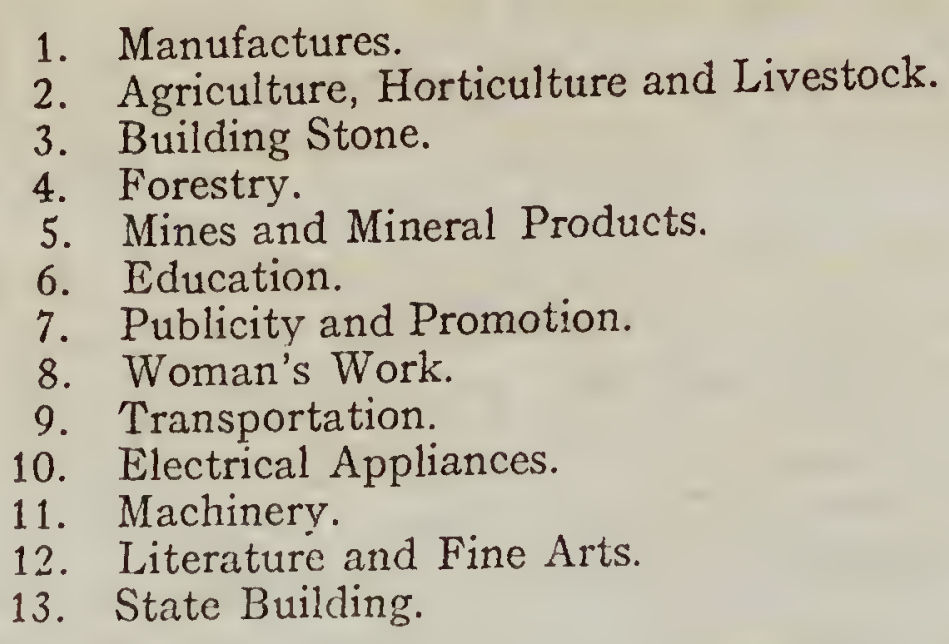

The Building Committee was first appointed, consisting of Messrs. Ball, Kinsey and O'Brien. This Committee immediately took up the question of a state building and advertised for competitive plans to be submitted to the Commission by the various architects of Indiana. After the submission of these plans, upon the recommendation of the Committee, the Commission finally unanimously adopted the plans prepared by Wing \& Mahurin, Architects, of Fort Wayne. The general plan of this building was that of a clubhouse, the architecture partaking largely of the character of the French Renaissance. The building was designed to be open to the public generally and to the citizens of Indiana especially, there being no private apartments excepting the working rooms of the Commissioners. It was spacious' containing large lounging halls and rest rooms, and we feel that inside and out, it was attractive and inviting to the guests of the Exposition. Within the building as afterward constructed was a large lunchroom, provided with proper facilities for rest and refreshment. These accommodations were furnished free of charge, as were also the checkroom in the building and the post office privileges. Thousands of people availed themselves of these accommodations. They were features of the building that were highly appreciated by all visitors. There was also a large room, beautifully lighted and decorated, which was designated as the music room. Upon the walls of this room and other parts of the building, about one hundred of the best pictures produced by the brushes of Indiana artists were displayed. Not only were these paintings beautiful and attractive in themselves, but they served to give a character and tone to the building which it otherwise would not have possessed. In this building was also a large reading room in which could be found at all times during the Exposition, complete files of all the principal newspapers published in Indiana, and there was another room devoted to the literature which has been produced by Indiana people. In it were original manuscripts of the most noted Indiana authors and a library of Indiana books, which called the attention of visitors to the literary achievements of our state. In the decoration and furnishing of this 
building we utilized the judgment of a committee of artists well known throughout Indiana. The members of this Committee served without pay, and suggested each tone and color that was placed upon the walls, the floors, and displayed in the tapestries, rugs and other furnishings. This Committee deserves special mention for untiring efforts to assist in giving evidence that Indiana has a large measure of culture and artistic excellence. The Building Committee from the time of its appointment until the state building was completed and furnished, had very important duties and upon it was entailed a very large amount of labor.

The Commission early took action looking to the careful safeguarding of the funds which were placed in its hands and the provision was made in the rules that no bill should be approved by the President and Secretary nor allowed by the Commission until it was first approved by an Auditing Committee. This Committee was appointed and all bills were carefully scrutinized. Those appointed upon the other Committees were as follows:

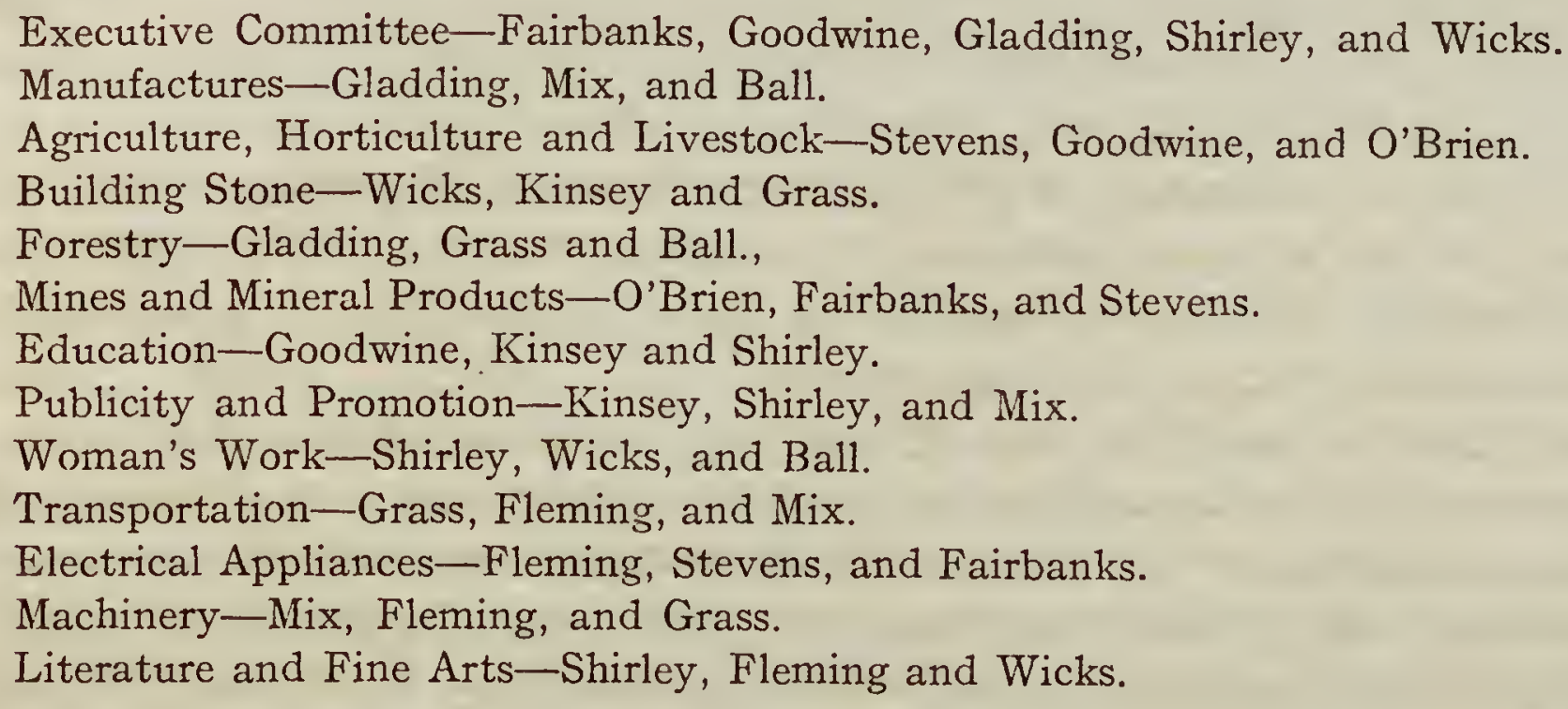

In several of the departments covered by these Committees, notably, Manufactures, Transportation, Machinery and Electrical Appliances, the Committees gave every possible aid to individual exhibitors in the various classes. This report would not be complete if it did not give a list of Indiana individual exhibitors and the splendid showing made by them. At another point in the report will be found a list of such exhibitors, together with the prizes taken by them. In all there were awarded to Indiana exhibitors, including the state exhibits, many hundred prizes. It 'was subsequently decided by the Commission to make no special effort to display "the forestry interests of our state.

The Committee on Publicity and Promotion immediately took up the work of exploiting the Exposition and Indiana's part therein throughout the state of Indiana. Their work will be more particularly spoken of at another place in this report.

It was the effort of the Commission to make the exhibit in the departments of Agriculture, Horticulture and 
Livestock extensive enough to show fully our great resources in those industries. The Committee having these matters in charge, spent a very large amount of time and much effort in order to secure creditable exhibits, and we feel sure that satisfactory results were secured. This matter will be treated in detail in another part of this report.

It was determined by the Commission that the state should make an extensive exhibit of Indiana oolitic limestone, which has become such a popular building stone throughout the country. Such a display was made, and we feel that these interests were thereby largely furthered. The stone used in the exhibit was furnished to the state free of charge by those interested in this industry, but the state paid for preparing and maintaining the exhibit. A similar exhibit was made of the coal interests of the state, the coal being furnished by those interested in its mining, but the exhibit was prepared, set up and maintained by the Commission.

In the Department of Education special effort was put forth, and the Committee having this in charge exhausted every resource in securing adequate representation for Indiana's educational advantages. A detailed statement follows in another part of this report, showing the extent and character of this exhibit.

The Committee on Woman's Work took up especially the display of ceramics and needle work, which was the product of the hands of Indiana women. The display of ceramics was placed in the Varied Industries Building and attracted wide attention, and that of needle work was placed in the Manufactures Building. We feel sure that the effort and money expended along these lines brought the best returns.

As indicated on a former page, the literature and fine arts of Indiana were displayed within the building. Thus the work in the various departments which the Commission undertook to exploit, was divided and placed largely in charge of a special committee appointed to look after each department; each committee, however, being required to submit to the Commission at its regular monthly meetings reports of what it proposed to do, and to receive the authority of the Commission before entering upon any considerable expenditure. It was early determined to restrict expenditures to the lowest possible point consistent with the proper representation of our state, and we take particular pride in pointing out the fact that out of the original appropriation made by the General Assembly of 1903, a large amount of money will be returned to the State Treasury, and that from the salvage of the building and furnishings another considerable amount was secured.

For a detailed statement of receipts and expenditures from the organization of this Commission until the present time, we refer you to another part of this report. All moneys expended were fully covered by vouchers.

The Commission desires to make acknowledgment to the four piano manufacturers of Indiana, for the magnificent instruments which they placed in the building during the Exposition period for the use of the public. The Packard Co., of Fort Wayne; Star Piano Co., of Richmond; Krell-French Piano Co., of New Castle, and the Schaff Bros. Piano Co., of Huntington, each contributed an instrument. They were placed in the various parts of the building, and were the source of much pleasure to Indiana people. To the artists and writers who furnished the 
pictures and books to be placed within our state building, we are also under many obligations. In addition thereto they have added to the lustre of Indiana's name throughout the world.

Our building was very fortunately situated in relation to other buildings upon the Plateau of States. Across its threshold as nearly as we can estimate upon reliable data, more than two million persons passed. Close to five hundred thousand people registered within the building. It was the effort of the Commission to give from time to time modest entertainments within the building, and we feel that the money expended in this direction was a wise outlay. Of the various entertainments given, we desire to mention especially but two, the one given at the dedication of the building and the one upon "Indiana Day," which was designated by the Exposition Company as September 1. On each of these two occasions a somewhat extensive program was rendered during the day, followed by a reception at night within the Indiana Building. Upon the date of the dedication, June 3, the program of exercises included a parade from the Administration Building across the grounds to the Indiana Building, which was largely interfered with by rain. Speeches within the building were given at 2 P.M., by Hon. David R. Francis, President of the Exposition; Hon. Rolla Wells, Mayor of St. Louis; Hon. Winfield T. Durbin, Governor of Indiana; and the President, Vice-President and Chairman of the Building Committee of the Commission. A reception was given at night in honor of Governor and Mrs. Durbin, and was rendered notable by the presence of hundreds of ladies and gentlemen from all parts of Indiana. The program on "Indiana Day" was of a somewhat similar character and was highly pleasing and creditable.

It was early discovered that in order to provide for the comfort and convenience of those who called at the building, there should be almost constantly present some lady from Indiana to receive them and extend to them the freedom of the building and the courtesies it afforded. The wives of the various Commissioners were asked to perform this duty, and in almost every case consented, each spending a few days there, and turning the duties over to another when convenience demanded.

The Commission was exceedingly fortunate in securing Acil C. Alexander, of Marion, Indiana, as Assistant Secretary. The duties of his position were enlarged by the Commission from time to time until he became practically the superintendent of all departments of Indiana's work at St. Louis when some officer or member of the Commission was not present. To his advice, assistance and earnest efforts is due a very large measure of the success of our exhibits and of the management of the Indiana State Building. In the early days of the Commission we also employed Miss Hallie McNeil, of Peru, Indiana, as stenographer and assistant in our office. She soon became thoroughly conversant with every detail of the various undertakings which the Commission inaugurated, and was exceedingly valuable not only for the services for which she was originally employed, but in performing the multiplied duties which increasingly devolved upon her. To these two the Commission owes special acknowledgment for their splendid services. Almost without exception, however, those employed in assisting either in the preparation or maintenance of the various exhibits and in caring for our state building, rendered efficient service, and helped to give Indiana a high place at this Exposition. 
Upon the conclusion of the Exposition as provided by law, we disposed of the building and furniture belonging to the state which had been used during the Expcsition period. After considering the various methods of disposing of this property, which at St. Louis at that time was a drug upon the market, we decided to offer it for sale at auction to the highest bidder, the building by itself and the articles of furniture piece by piece. We advertised this sale in the Indianapolis newspapers, and conducted it on the 30th day of November, at the Indiana Building. Both the building and the furniture brought somewhat larger sums than had been anticipated.

A detailed account of the work of the various Committees in the several departments to which we have already referred, follows:

\section{Agricultural Exhibit}

Very soon after the organization of the Commission, the Committee on Agriculture began active work for the adequate representation of Indiana's agricultural interests at the Exposition, and formulated plans for the collection of agricultural specimens to be used in the exhibit. It was found necessary to have a representative agriculturalist in many of the counties of the state, to collect these specimens and generally have in charge the work undertaken by the Committee as far as it related to those counties. The following gentlemen accepted appointment as local representatives of the Commission and rendered valuable services:

County.

Bartholomew

Boone

Cass . . .

Clinton

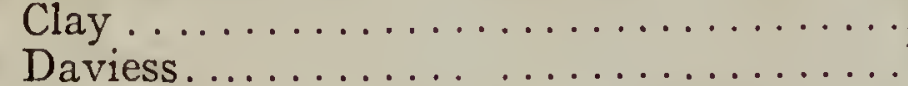

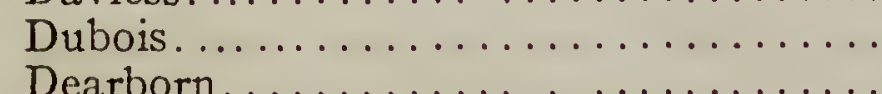

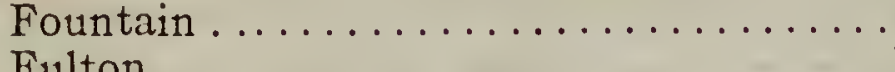

Fulton

Greene $\ldots \ldots \ldots \ldots \ldots \ldots \ldots \ldots \ldots \ldots \ldots \ldots \ldots \ldots \ldots \ldots \ldots \ldots$
Gibson $\ldots \ldots \ldots \ldots \ldots \ldots \ldots \ldots \ldots$

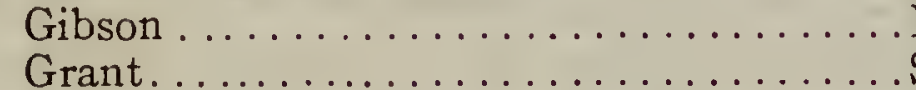

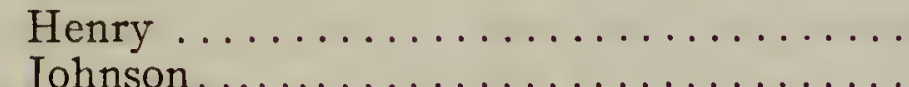

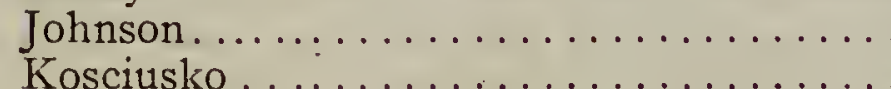

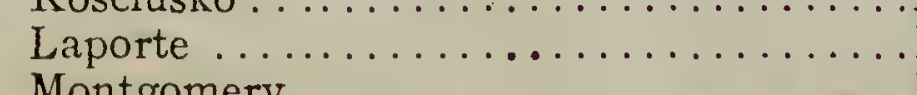

Montgomery $\ldots \ldots \ldots \ldots \ldots \ldots \ldots \ldots \ldots$

Newto

Noble.
Name.

Redman, Ed., Jr.

Stephenson, S. T .

Campbell, B. F

Maish, D. F.

Whisman, S. A . . . .

Hemmer, E. B....................... Huntingburg.

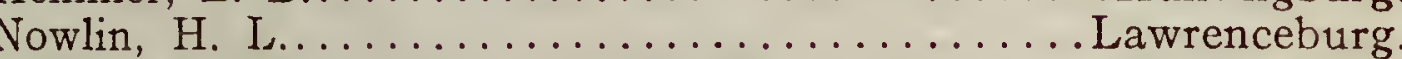

Remster, Smith...................... Veedersburg

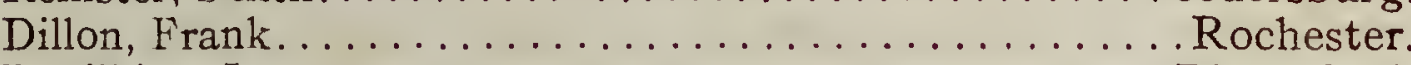

Devilbiss, $L \ldots \ldots \ldots \ldots \ldots \ldots \ldots \ldots \ldots \ldots \ldots \ldots \ldots$ Bloomfield

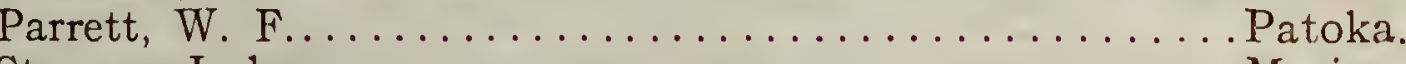

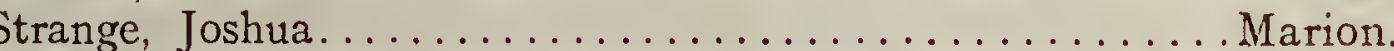

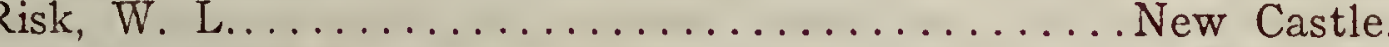

Clore \& Overstreet. . . . . . . . . . . . . . . . . . . Franklin.

Diehl, E. F............................ Leesburg.

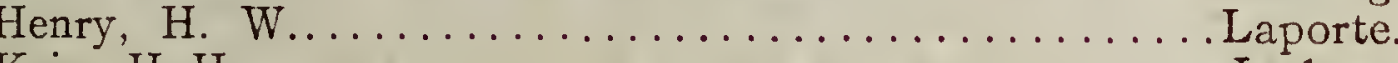

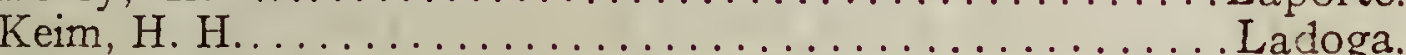

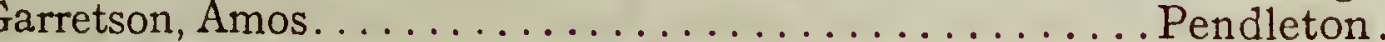

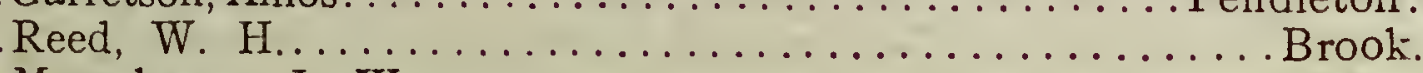

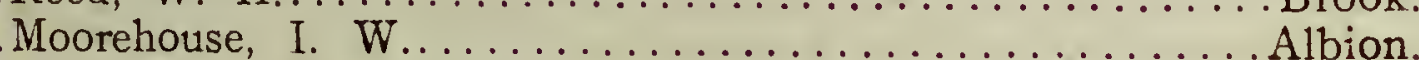




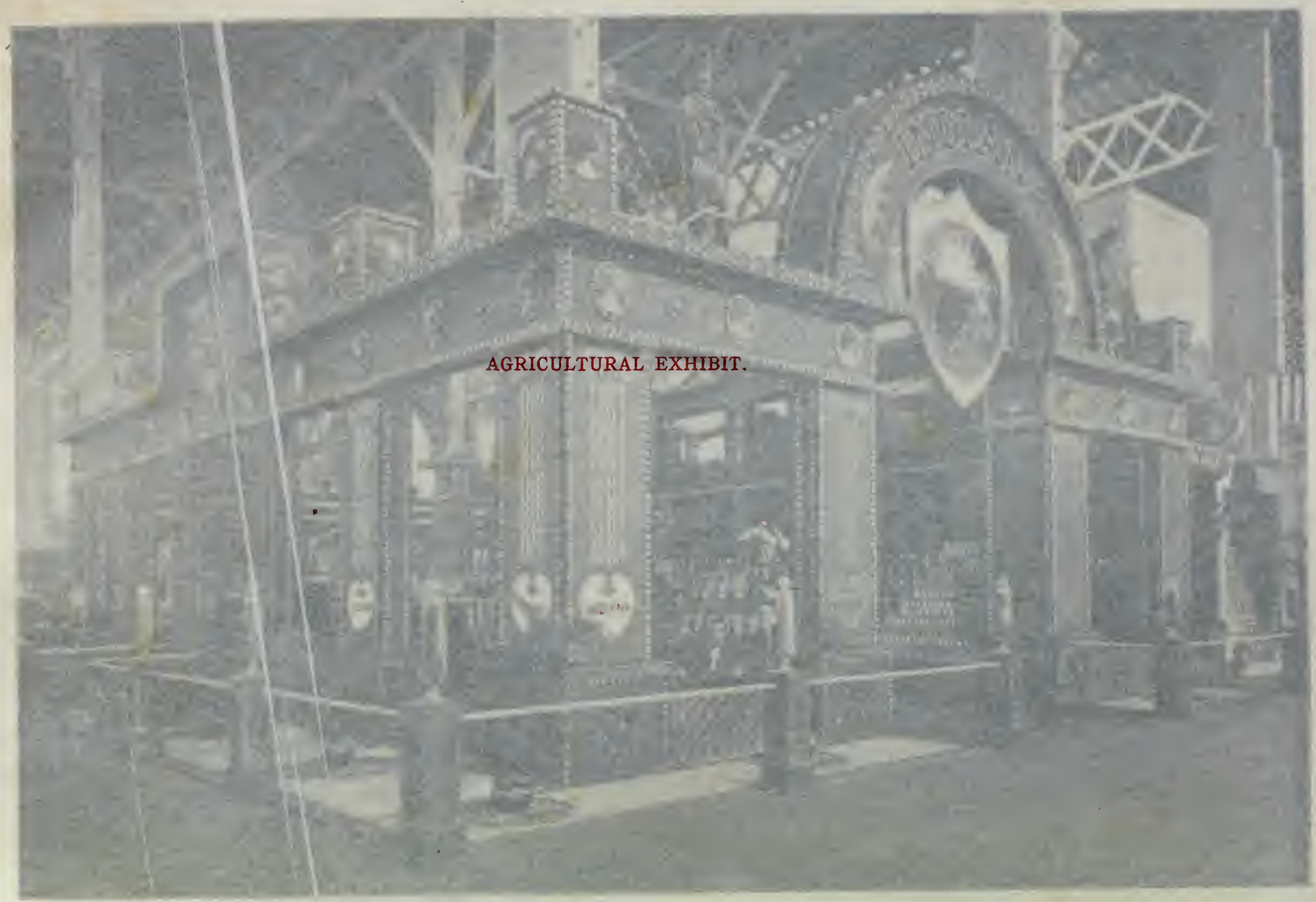




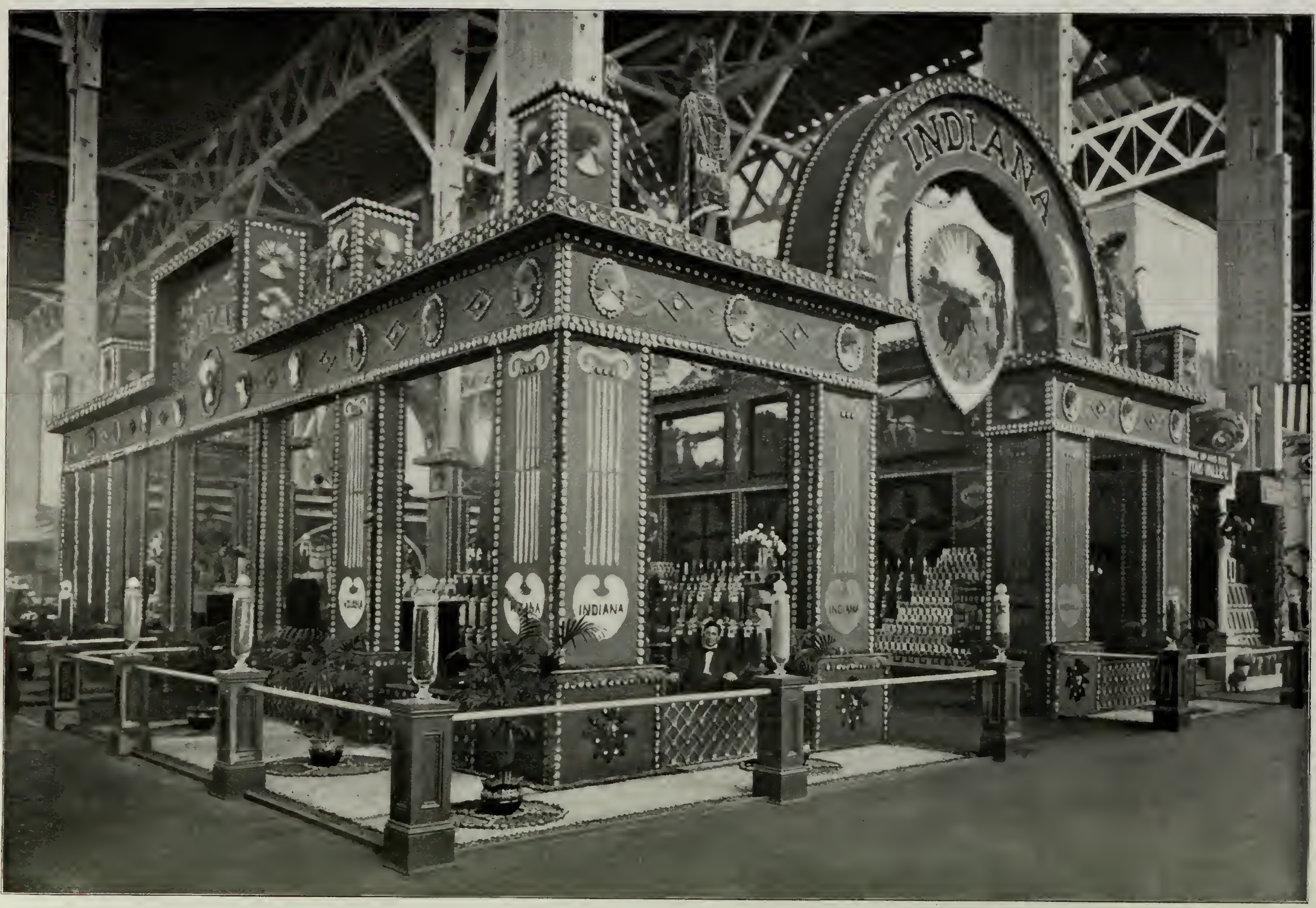





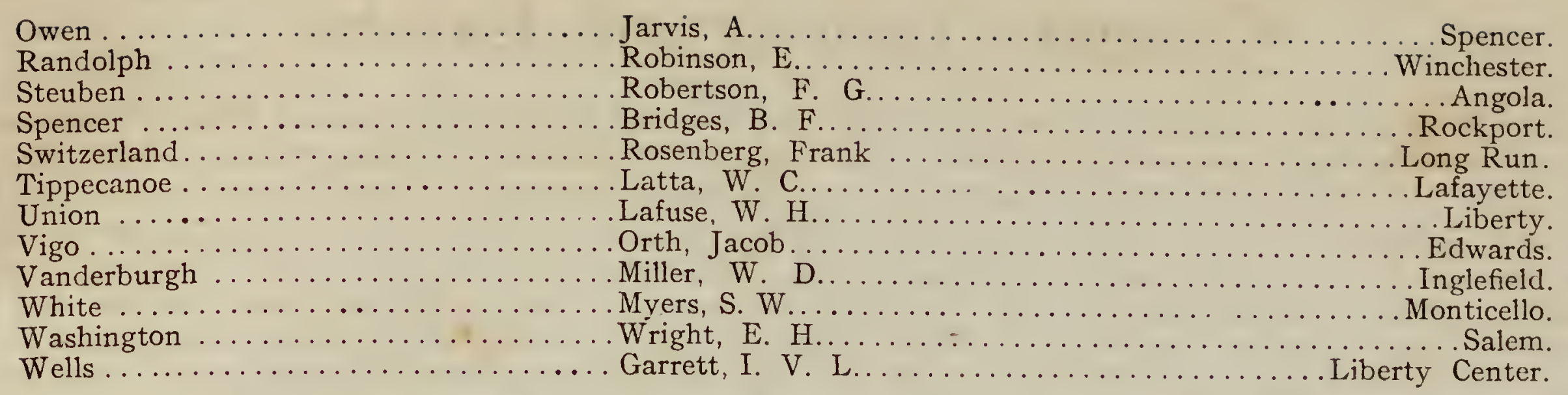

The classification of exhibits by the Department of Agriculture of the Louisiana Purchase Exposition, made it necessary for this Commission to install its exhibits in two different spaces, one of which was devoted exclusively to corn and the other to general agricultural products. Plans for these exhibits submitted by Messrs. L. B. Clore and Jos. R. Overstreet, of Franklin, Indiana, were approved by the Committee, and these gentlemen were employed to superintend the collecting of materials and the construction of the exhibits, and afterwards to have charge of the same during the Exposition period.

\section{Corn Exhibit}

The corn exhibit covered a space of $2,308 \mathrm{sq}$. $\mathrm{ft}$. The main feature of the exhibit was a pyramid of corn $41 \mathrm{ft}$. in height, surmounted by a statue of "Corn King" $8 \mathrm{ft}$. in height, holding a mammoth stalk of corn $14 \mathrm{ft}$. in length. This pyramid was decorated with four large pictures worked out in colored grains, portraying the progress of agriculture and the advancement in farm life in this state. The space was enclosed with a nickel-plated railing, within which were grouped about the pyramid, large show cases displaying the choicest varieties of grain grown in the state. This exhibit received four grand prizes, as follows:

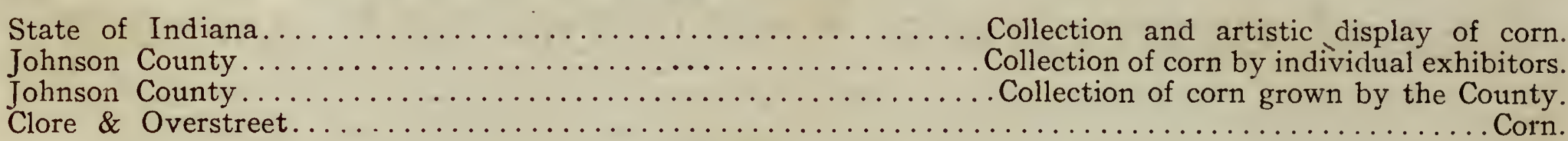




\section{General Agricultural Exhibit}

The space devoted to the exhibit of general agricultural products covered an area of $2,787 \mathrm{sq}$. ft., and was directly opposite the space devoted to the corn exhibit. This space was enclosed by a facade $16 \mathrm{ft}$. in height, with a spacious arched entrance $26 \mathrm{ft}$. in height. The exterior and interior decorations of the facade were worked out in agricultural products, including straws, grasses, husks, etc, as well as grain, arranged in artistic groupings creating a pleasing effect. In the center of this space, as in the corn exhibit, was a pyramid $41 \mathrm{ft}$. high, decorated with agricultural specimens and pictures in harmony with the decorations of the facade. At the apex of the pyramid was placed a statue representing "Liberty" supporting a sheaf of wheat in her arms. Within the enclosure were placed a number of pictures done in grain and other farm products. Within the space, on tables and in cases, were displayed agricultural products and the products of Indiana canneries. In this department the following medals were awarded to the state:

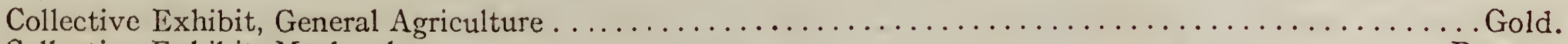

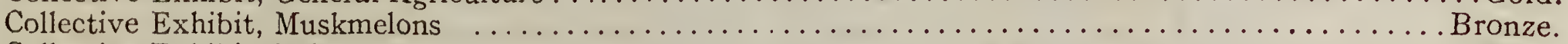

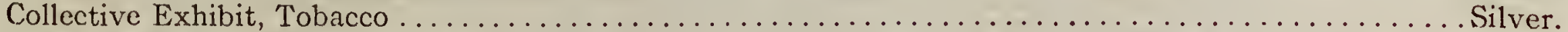

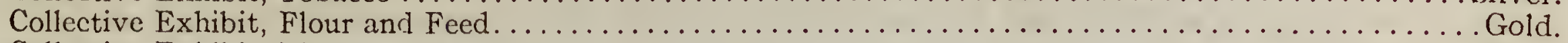

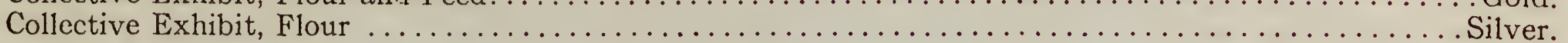

The following counties were awarded medals on collective exhibits:

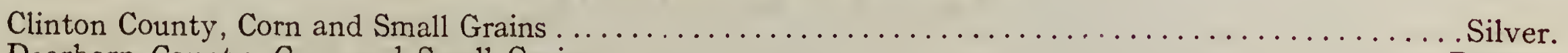

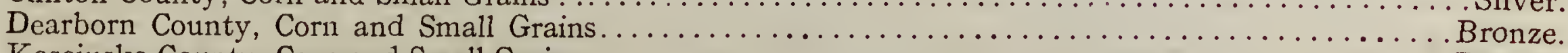

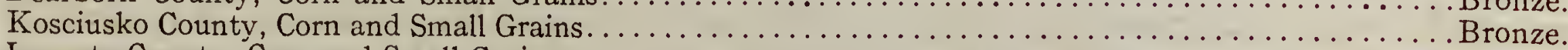

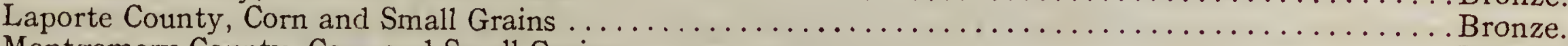

Montgomery County, Corn and Small Grains $\ldots \ldots \ldots \ldots \ldots \ldots \ldots \ldots \ldots \ldots \ldots \ldots \ldots \ldots \ldots \ldots \ldots \ldots \ldots \ldots \ldots \ldots \ldots$

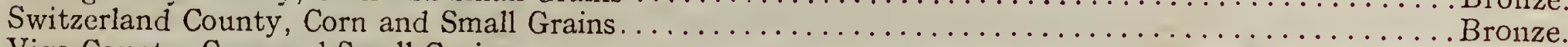

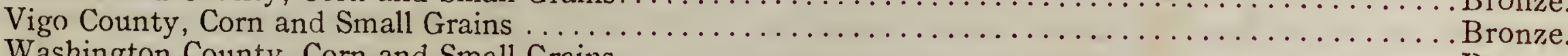

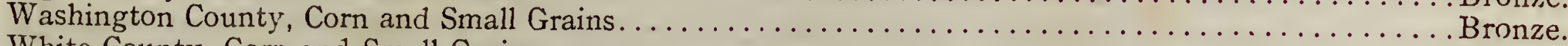

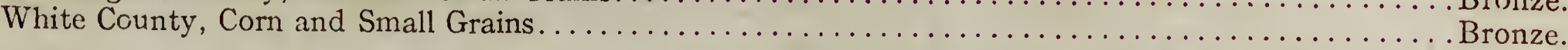

\section{List of Agricultural Exhibitors and Awards} GROUP 84

Miller, Sebastian

Residence.

Exhibit.

Award.

Fort Wayne

Potatoes

Silver.

BOONE COUNTY.

Anderson, Thos..

Lebanon ............. Wheat

Silver.

Flickenger. Henry A.

Corn

Bronze. 


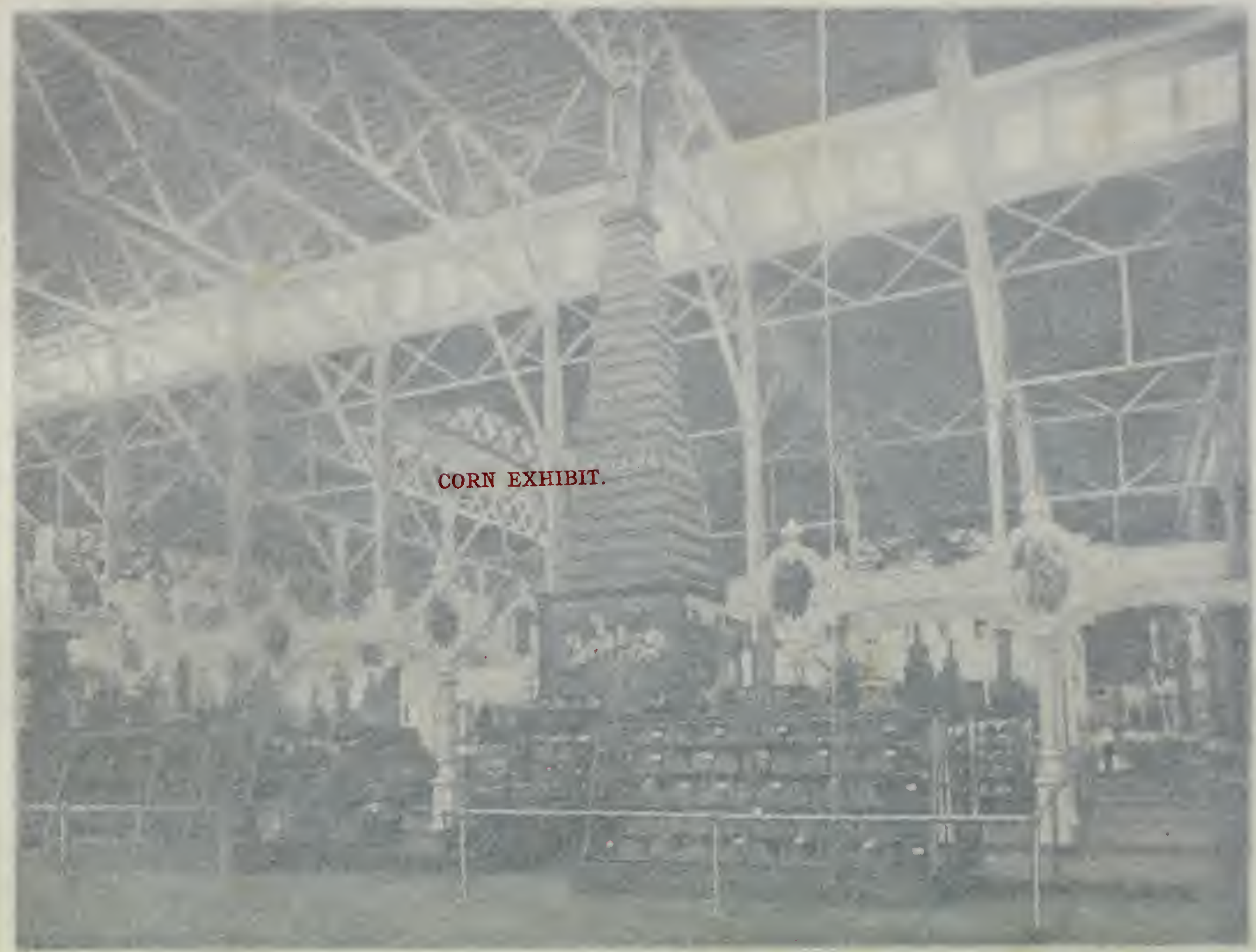

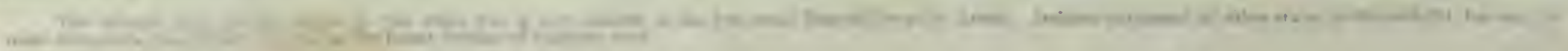




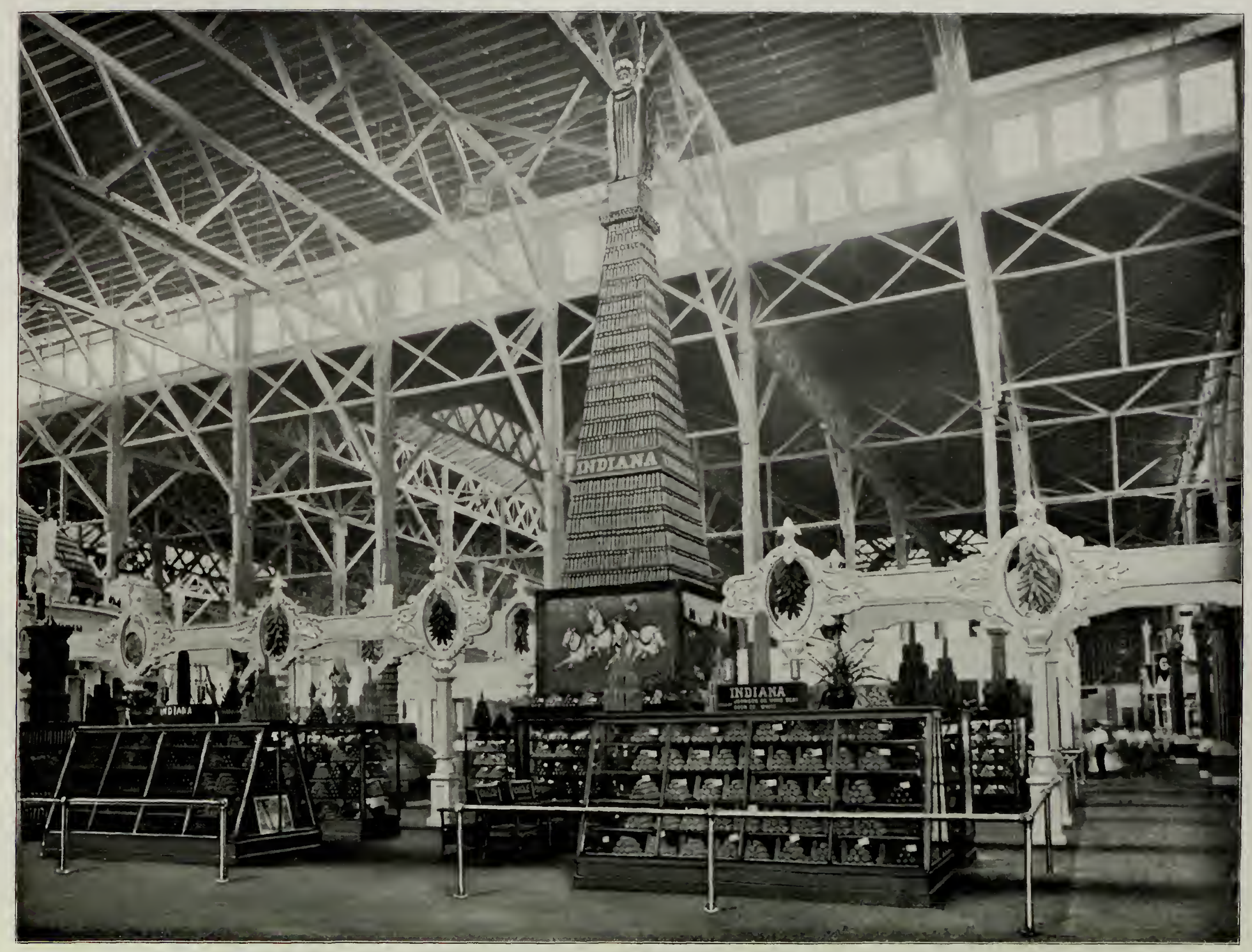

The special corn exhibit made by the state was a new feature at the Universal Exposition at St. Louis. Indiana surpassed all other states in this exhibit, having the
most attraetive presentation as weil as the finest display of superior corn. 
Powell, Geo.

Elizaville

Riley, Harley

Thorntown

Wheat.

Stevenson, S. T

Lebanon

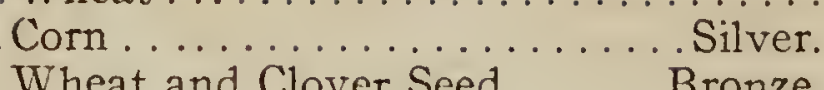

Lebanor.

Shirley, - N $\mathrm{N}$.

Alfalfa Hay

\section{BARTHOLOMEW COUNTY.}

Blessing, H. B

Chambers, R. W

. Columbus

Columbus .

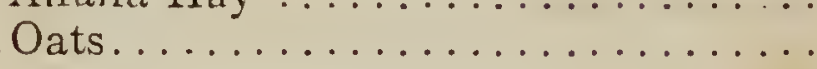

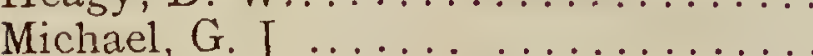

Muir, Wm. .

Columbus

Columbus

Wheat and Oats

Pierce, James C.

Taylor, J. A.

Columbus

Barley

Columbus

Oats and Wheat.........................

Newsom, J. S.

Elizabethtown

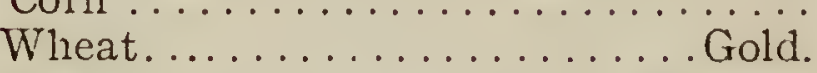

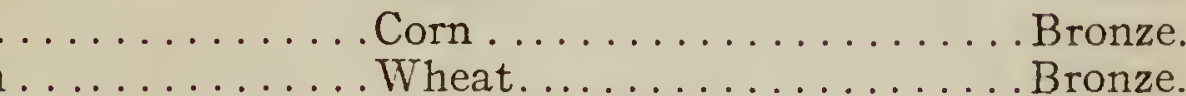

Brockman, W. F. . . . . . . . . . . Hartsville

Voglar, L. A.

Hope.

Heagy, D. W

. Azalia

Mitchell, G. J.

. Azalia.

. Columbus

Oats and Wheat............. Silver.

Wheat and Clover Seed ...... Bronze.

Corn ................... Silver

Corn and Clover Seed

Silver.

Clover Seed. ............... Bronze.

CASS COUNTY.

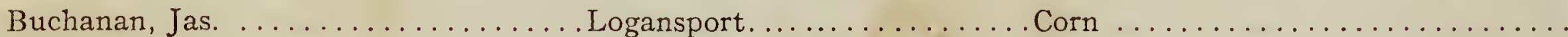

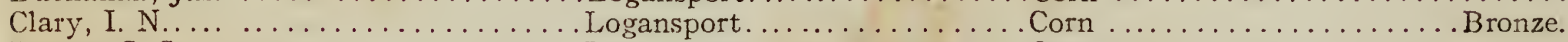

Brown, S. S. . . . . . . . . . . . . . L Logansport. ............... Oats . . . . . . . . . . . . . . . . .

Homburg, Henry ............... Logansport. .............. Corn . . ................

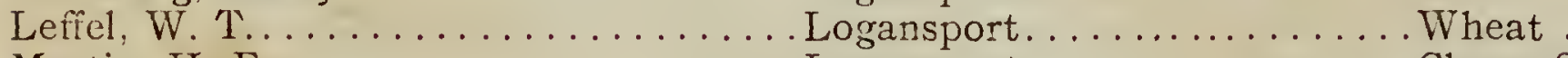

Martin, H. E. . . . . . . . . . . . . . . . . Logansport. . . . . . . . . . . . . . Clover Seed . ................ Bronze

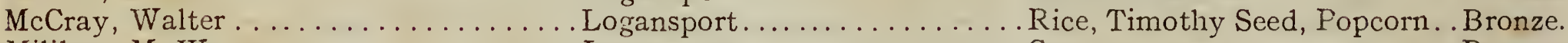

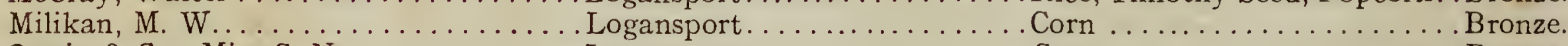

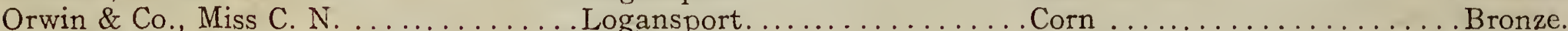

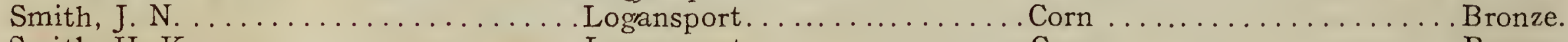

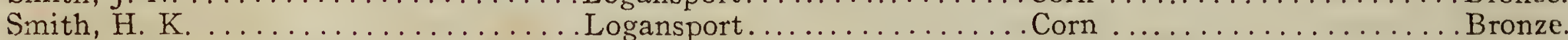

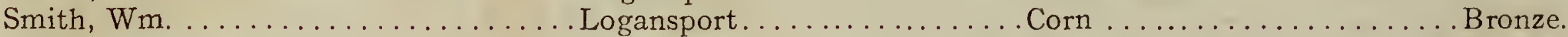

Uhl, Elmore . . . . . . . . . . . . L Logansport. . . . . . . . . . Clover Seed .............. Bronze.

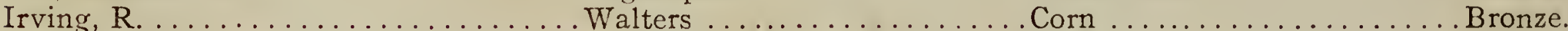

\section{CLINTON COUNTY.}

Armtrout \& Son

Frankfort

Bilcher, B. H.

Frankfort

Corn and Clover Seed.

Gold.

Baker, L.

Jefferson

Corn

Bronze.

Branden, Abner

Michigantown

Corn

Bronze.

Branden, V.

Michigantown

Corn

Bronze. 


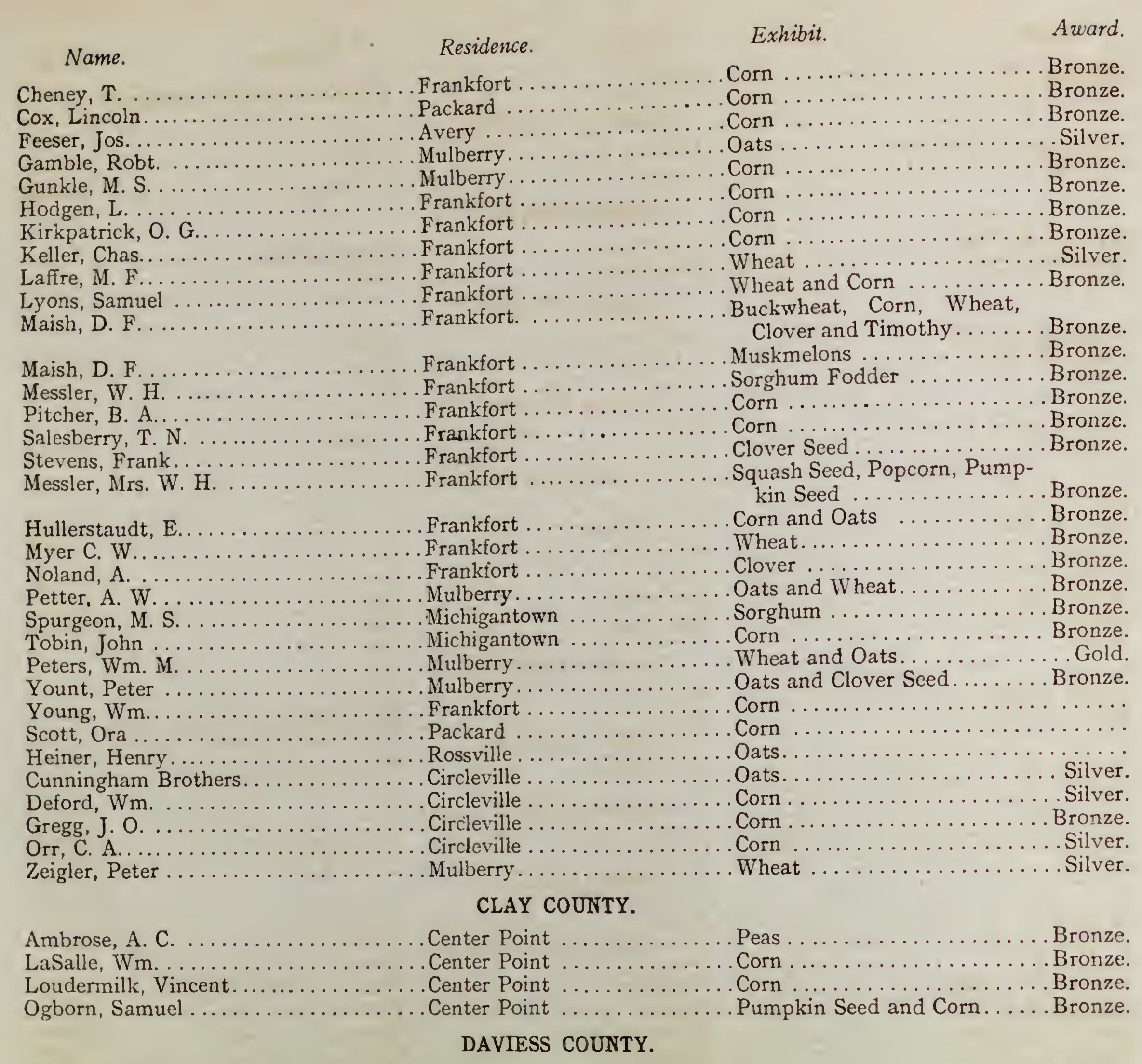

Killan, J. H.

. Elnora

Corn

Bronze. 
Wiseman, S. A.

. Elnora

Wheat, Oats, Clover Seed, Corn ......

DEARBORN COUNTY.

Cottingham, T. B

Lawrenceburg

Corn

Silver.

Taft, E. C

\section{DUBOIS COUNTY.}

Hemmer \& Sons

Huntingburg

Wheat and Corn

Silver.

Burgdors, Fred.

Huntingburg

Corn

FOUNTAIN COUNTY.

Sprangle, Wesley

. Veedersburg

Wheat

Covington.

Corn.

\section{FULTON COUNTY.}

Gordon, S. V.

Rochester

Corn

Bronze

\section{GREEN COUNTY.}

Axe, J. W.

Bloomfield

Bloomfield

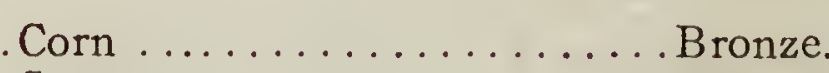

Cravens, Jos.

Bloomfield

Corn

Bronze.

Crawford, J

Bloomfiel

Corn

Wilkie, Leroy

Bloomfiel

Corn ................. Bronze

Moore, E. N.

Johnston

Corn .................. Bronze

\section{GRANT COUNTY.}

Pence, John

Mier

Corn

Strange, Joshua A

Marion

Clover Seed and Timothy Seed.

Haines, $\mathrm{H}$.

HENRY COUNTY.

New Castle .....................

GIBSON COUNTY.

Hunter, Wm.

Princeton

Watermelons

Bronze.

\section{JOHNSON COUNTY.}

Adams, W. A

Franklin

.Corn . . . . . . . . . . . . . . Silver.

Aikens, Joseph . . . . . . . . . . . . Franklin

Popcorn Bronze.

Bailey, S.

Franklin

Barnhiser, Frank ................Franklin .

Corn . . . . . . . . . . . . . Bronze

Buckhard, G. R. ............... Franklin

Corn ............ Bronze.

Brasley, Adolph..................... Franklin .

Corn ....................... Silver

Brown, C. A. . . . . . . . . . . . . Franklin

Corn $\ldots \ldots \ldots$ Silver

Brown, I. N................... Franklin

Corn ................. Silvee.

Corn . . . . . . . . . . . . Bronze 
Name.

Butler, J. P.

Residence.

Exhibit.

Award.

Clemen, S. U.

Franklin

Clore, L. B.

Franklin

Clore, Joel.

Franklin

Coons, Wm.

Franklin

Cover, C. J.

Franklin

Covert, Grant

Franklin

Davis, C. C. .

Franklin

Drake, Morris ....

Franklin

Deere. Will ....................... Franklin

Franklin

Devore, Bertha .................. Franklin .

Devore, Chester

Franklin

Dillman, Ollie.

Franklin

Ditmarsh, C. L.

Franklin

Dragoo, T. J.

Franklin

Dragoo, Roy.

Franklin

Dungan, C. A.

Franklin

Dungan, Mrs. C. A

Funkenbiner, D. E

Franklin

Fletcher, John.

Grose, D. S.

Franklin

Harris, J. D.

Franklin

Held, Chris

Franklin

Henderson, J. F

Franklin

Jones, E. B

Franklin

Jones, E. B ....................... Franklin

Kerlin J. Paul,

Franklin

Kelley, Joe.................... Franklin

Franklin

Leach, Ira.

Franklin

Leach, J. T.

Franklin

Franklin

Lockery, Ralph

Franklin

Overstreet, Joe R

Franklin

Owens, Leslic

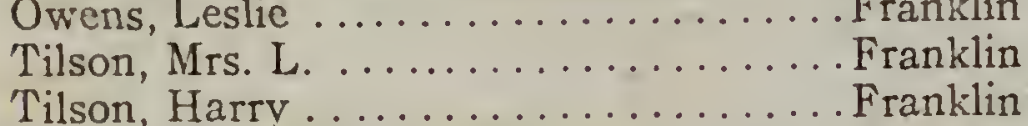

Corn

Bronze.

Bronze.

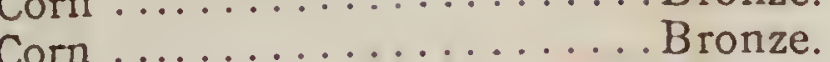

Tilson, Mrs. Harry ............... Franklin

Corn

Bronze.

$\ldots \ldots \ldots \ldots \ldots \ldots$

Corn

Bronze.

................ Corn

Bronze.

Corn .................... Bronze.

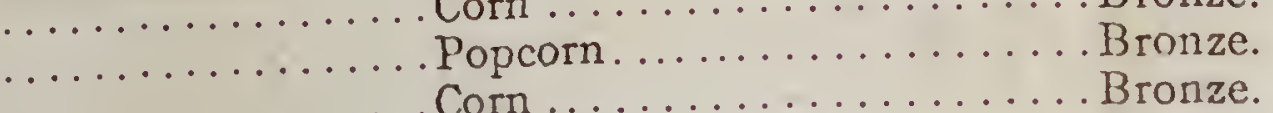

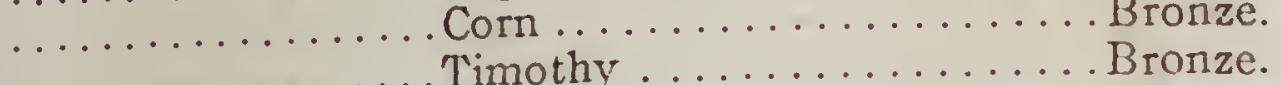

............... Timothy . . . . . . . . . Bronze.

Corn $\ldots \ldots \ldots \ldots \ldots \ldots$ Bronze.

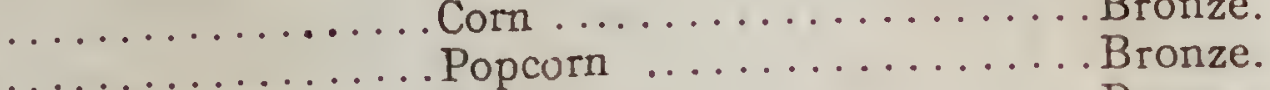

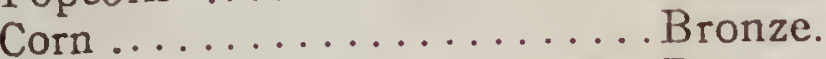

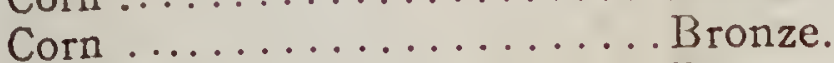

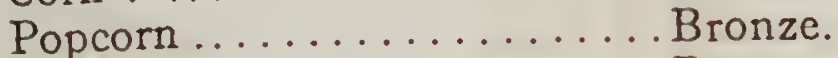

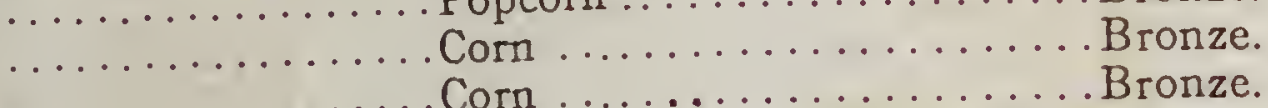

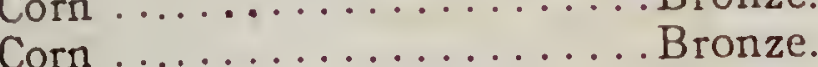

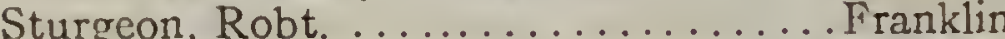

Franklin

Bronze.

Corn $\ldots \ldots \ldots \ldots \ldots \ldots \ldots \ldots \ldots \ldots$ Bronze.

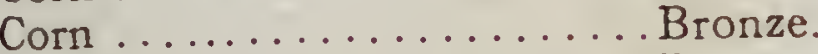

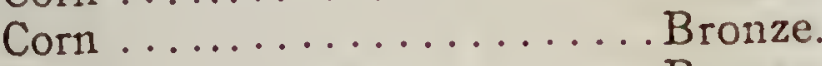

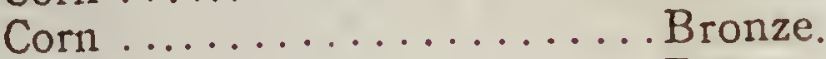

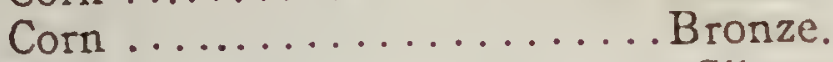

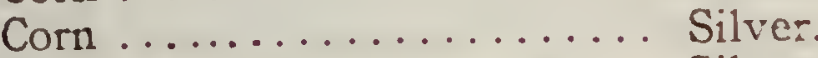

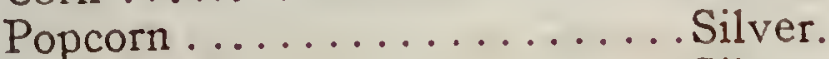

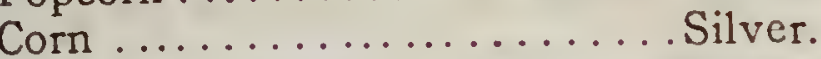

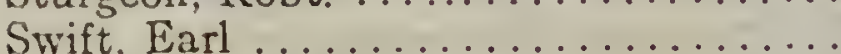

Staenbrook, John ..............Franklin

Franklin

Corn

Bronze.

Corn ................... Silver.

Smith, Ora

Smith, Ed. . . . . . . . . . . . . Franklin

Corn

Bronze.

Popcorn

Bronze

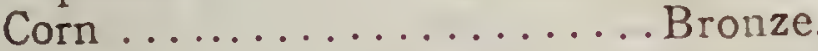

Corn

Bronze.

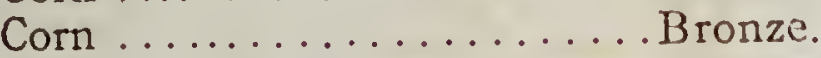

Smith, Ira W.

Franklin

Corn

. Bronze.

Corn ... . . . . . . . . . . . Bronze.

Corn .... . . . . . . . . . Bronze

Popcorn................. Bronze.

Popcorn. ................... Silver.

Corn . . . . . . . . . . . . . Silver.

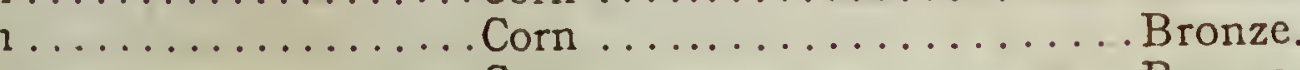


Rogers, Sanford

Franklin

Corn

Bronze.

Whits, D.........

Whitesides, David

Franklin ...................

Bronze.

Franklin

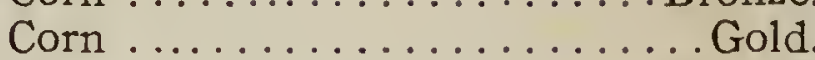

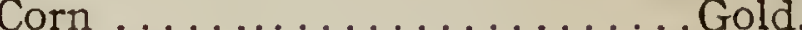

Young Clifford $\ldots \ldots \ldots \ldots \ldots \ldots \ldots \ldots \ldots$. Franklin $\ldots \ldots \ldots \ldots \ldots \ldots \ldots$ Bronze.

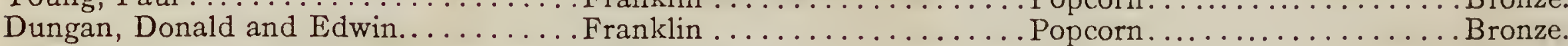

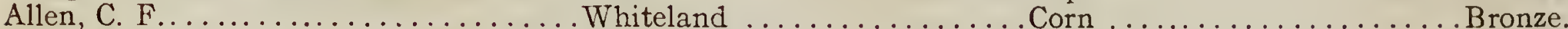

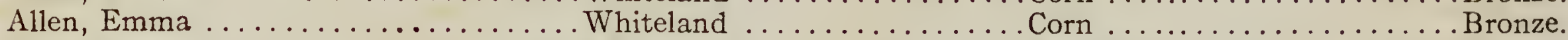

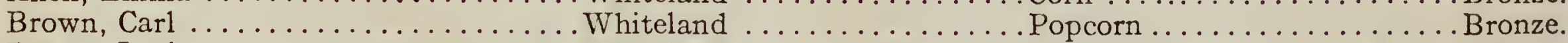

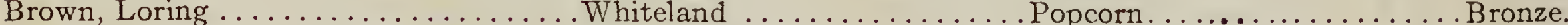

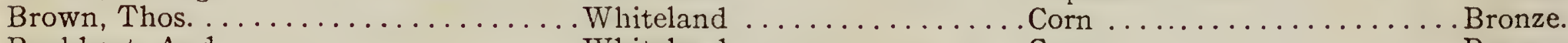

Buckhart, Andy...............Whiteland ............. Corn ................ Bronze.

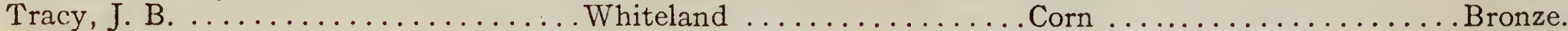

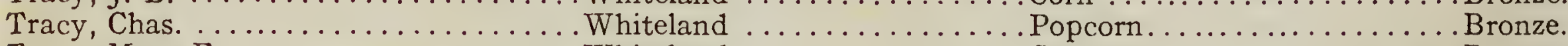

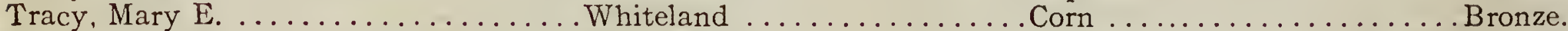

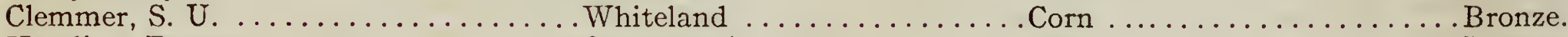

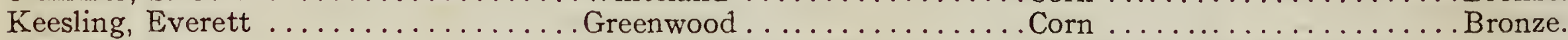

Johnson, G. ..................Greenwood ............. Tomatoes, Peas and Beans ... Silver.

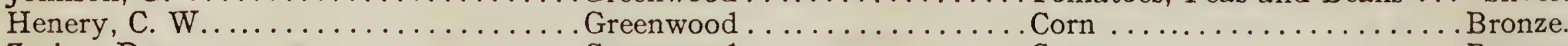

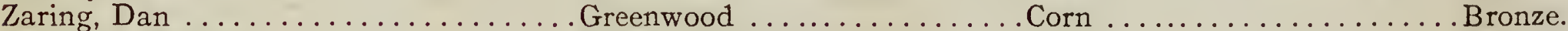

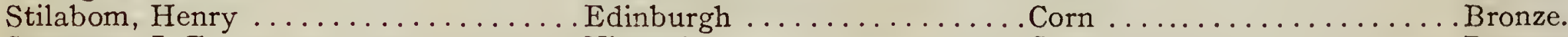

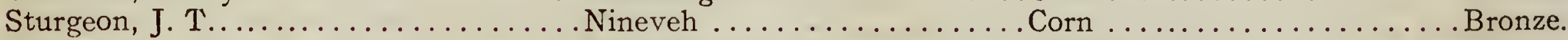

Tracey, L.....................Franklin . .............Popcorn................ Bronze.

\section{KNOX COUNTY.}

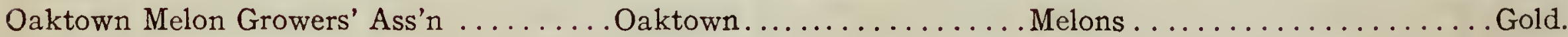

\section{KOSCIUSKO COUNTY}

Name.

Residence.

Exhibit.

Award.

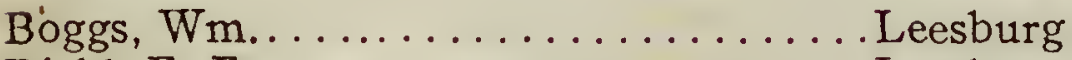

Diehl, E. F. . . . . . . . . . . . Leesburg

Oats

Wheat, Oats, Corn, Peas and

Clover Seed ............... Gold.

Feronda, Hiram.........................

Corn

Harrison, Corwin . ................ Leesburg. .

Corn .............................

Zimmerman, Marvin

\section{Leesburg.}

Wheat, Oats and Corn

Silver.

Brink, Ed

Rogers, G. W

Watson, A. J.

Clayton, Chas. B.

Closser, D. P.

Cook, G. C.

\section{LAPORTE COUNTY.}

Door Village.

Door Village.

Door Village.

Kingsbury

Kingsbury

La Crosse.
Wheat, Oats and Clover Seed

Wheat................. Bronze.

Wheat ...................... Silver.

Buckwheat .................... Silver

Millet ................. Silver.

Corn .................. Bronze. 
Name.

Henry, W. H

Weigner, Jos.

Shanks, Wm.

Headley, F.

Wrenger, Jas.

Wood Brothers

McCarty, C. E

Noland, Alonzo

Wood, Clifford

Marsh, J. W.

Caylor, C. W.

Frame, Marcus

Harshbarger, W. R

Swearenger, A. C

Moorhouse, J. W

Franklin, J. C.

Gagen, J. M.

Kamlin, L. E.

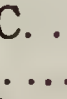

Bman

Cline, R.H.

Epitomist Experimental Station

Gilmore, Robt.

Jarvis, Earl.

Kune, Emmett.

Mills, David

Peden, Thomas

Williams, J. H.

Strouse -

Edwards, E.

bt.
ett.
Has

Milhous, J. J.

Residence.

Laporte.

Kingsbury

LaCrosse

LaCrosse.

Kingsbury

\section{MADISON COUNTY.}

Pendleton

Pendleton

Frankton

Pendleton

Muncie

\section{MONTGOMERY COUNTY.}

Ladoga

Ladoga

Ladoga.

Crawfordsville

Exhibit.

Award.

Wheat and Buckwheat ....... Bronze. Clover Seed . . . . . . . . . . . . . Gold.

Clover Seed ................ Gilver

Corn . . . . . . . . . . . . . . . . . Bronze

Corn ................... Bronze.

Clover Seed

Oats and Corn

Corn

Clover Seed

Corn . . . . . . . . . . . . . . Silver

Cucumber................Bronze.

\section{MARION COUNTY.}

Valley Mills

\section{NOBLE COUNTY.}

Albion

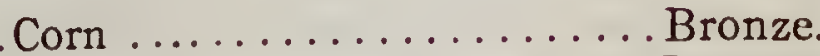

Corn .................. Bronze.

Corn ................... Bronze.

Corn and Wheat ..........Bronze.

Peppers.

Bronze.

Wheat, Oats and Corn

Gold.

NEWTON COUNTY.

Brook

Morocco

Corn and Oats

Bronze

Morocco

Corn

Corn . . . . . . . . . . . .

\section{OWEN COUNTY.}

Spencer

Spencer

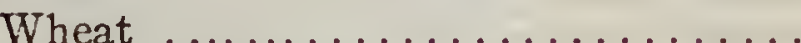

Spencer

Spencer

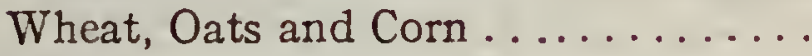

Spencer

Spencer

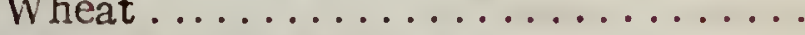

Spencer

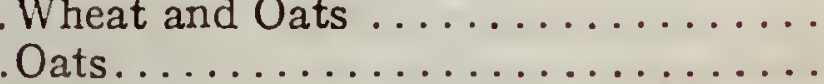

Spencer

Corn

Bronze.

Freedman

. Corn

Bronze.

Spencer

Wheat.

Bronze.

\section{RANDOLPH COUNTY.}

Cortner, Levi

Winchester

Corn 
Kemp, J. W

Winchester

\section{.Corn}

Bronze

Lasley, A.

Winchester

Miller, Wm. T.

Winchester

North, Wm.

Winchester

Corn

Bronze.

Thompson, Bert $W$

Winchester

Corn ................. Bronze.

Winchester

Corn ................. Bronze.

SWITZERLAND COUNTY.

Detmar, Andy

Archer, John

Vevay

Cotton, P. K

Vevay

Culbertson, Edgar . . . . . . . . . . . . V V vay

Rosenberg, Frank................... Vevay

Scott, Robt. ................. Vevay

Sharp, Robt. . . . . . . . . . . . . . . . Vevay

Weber, Fred. .................. Vevay

Wright, Lee $\ldots . . \ldots \ldots \ldots \ldots \ldots \ldots$. . Vevay

Anderson, J. B..................... Vevay

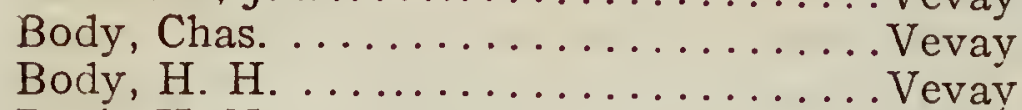

Buck, H. N. .................. Vevay

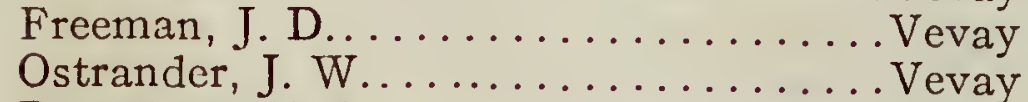

Rosenberg, E. C. ................ Vevay

Porter, J. P. . . . . . . . . . . . . . V Vevay

Weaver, Abe ................... Vevay

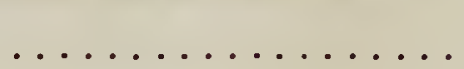

Wheat, Oats and Clover Seed..Bronze.

Wright, Jos. ................. Vevay

Corn .................. Bronze.

\section{STEUBEN COUNTY.}

Appleman, Squire

Angola

Corn ................... Silver

Wheat $\ldots \ldots \ldots \ldots \ldots \ldots \ldots$. . . . . .

Wheat $\ldots \ldots \ldots \ldots \ldots \ldots$. $\ldots \ldots$ Silver.

Avery, C. . . . . . . . . . . . . . . Angola

.............................

Crain, Hiram . . . . . . . . . . . Angola

Powers, S. A. .................... Angola

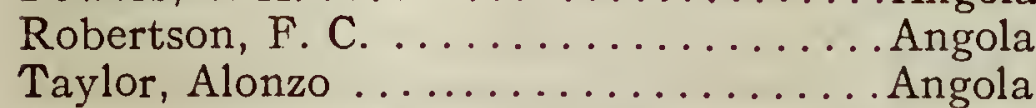

Avery, C.

Pleasant Lake.

Wheat and Clover Seed ....... Silver

Harphan, J.

Pleasant Lake.

Beans .................. Silver

Wheat .................. Silver.

Wheat $\ldots \ldots \ldots \ldots$. . . . . . . . .

Wheat $\ldots \ldots \ldots \ldots \ldots$. . Silver.

Corn . . . . . . . . . . . . Silver.

Corn ................. Bronze

Corn $\ldots \ldots \ldots \ldots \ldots \ldots \ldots \ldots \ldots$ Bronze.

Corn .................. Bronze.

Corn ................. Bronze.

Wheat.................. Bronze.

Oats . . .................. Bronze.

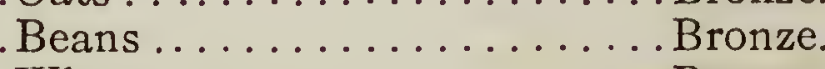

Wheat................. Bronze.

Wheat. . ................. Bronze

Wheat................... Bronze.

\section{SPENCER COUNTY.}

Bridges, B. F

Rockport

Clover Seed ............... Silver.

Bretz, J. P..

Rockport

Wheat.

Wheat ..................... Silver

Corn

.

Wheat

Corn

Oats and Beans ..
Oats and Barley.

Haines, J. A.

Rockport

Gold.

Kincade, Chas.

Rockport

Corn

Bronze.

Roberts, L. E

Rockport

Corn .................. Bronze

Corn, Wheat and Clover Seed

Wheat and Clover Seed ...... Bronze

Clover Seed ............. Bronze. 
Name.

Thomas, Geo.

TIPPECANOE COUNTY.

Purdue University

Lafayette. . .

23 Varieties of Wheat in Straw. . Silver.

\section{UNION COUNTY.}

Crawford, W. E

Liberty

Liberty

Corn

Silver.

Lafuse, Hiram.

Corn

Wheat and Corn................ Silver.

\section{VANDERBURG COUNTY.}

Knowles, J. R. . . . . . . . . . . . . . . Inglefiel

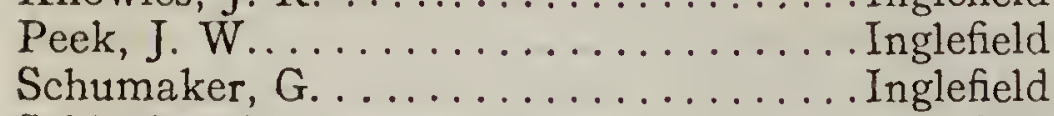

Schlusker, F.

Schlucker, C. J.

Inglefield

Ruskin, J. M.

\section{Inglefield}

Inglefield

\section{VIGO COUNTY.}

Athey, Robt. M

Edwards

Daniels, Fred.

East, John

Edwards

$\ldots \ldots \ldots \ldots$ Edwards

Overpeck, Geo. . . . . . . . . . . . . . . Edwards

Orth, Louis . . . . . . . . . . . . . . . . . . Edwards

Orth, Wm. .................. Edwards

Orth, F. J. . . . . . . . . . . . . . . Edwards

Orth, Jacob, \& Son . . . . . . . . . . Edwards
Seybold, J. H. . . . . . . . . . . . . Edwards

Seybold, J. H. ............... Edwards .

Baucrmeister, C. W. . . . . . . . . . . . . Terre Haute

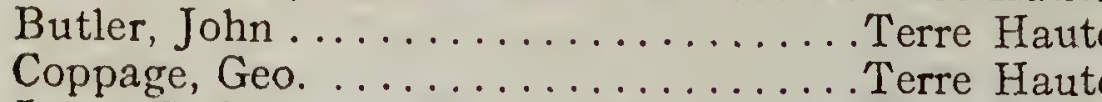

Jones, S. R. . . . . . . . . . . . . . . Terre Haut

Manel, Jos. . . . . . . . . . . . . . Terre Haute

Tyler, J. S. . . . . . . . . . . . . . . Terre Haute.

Simons, G. S

Terre Haute.

Myer, Albert J

Terre Haute.

Heckland

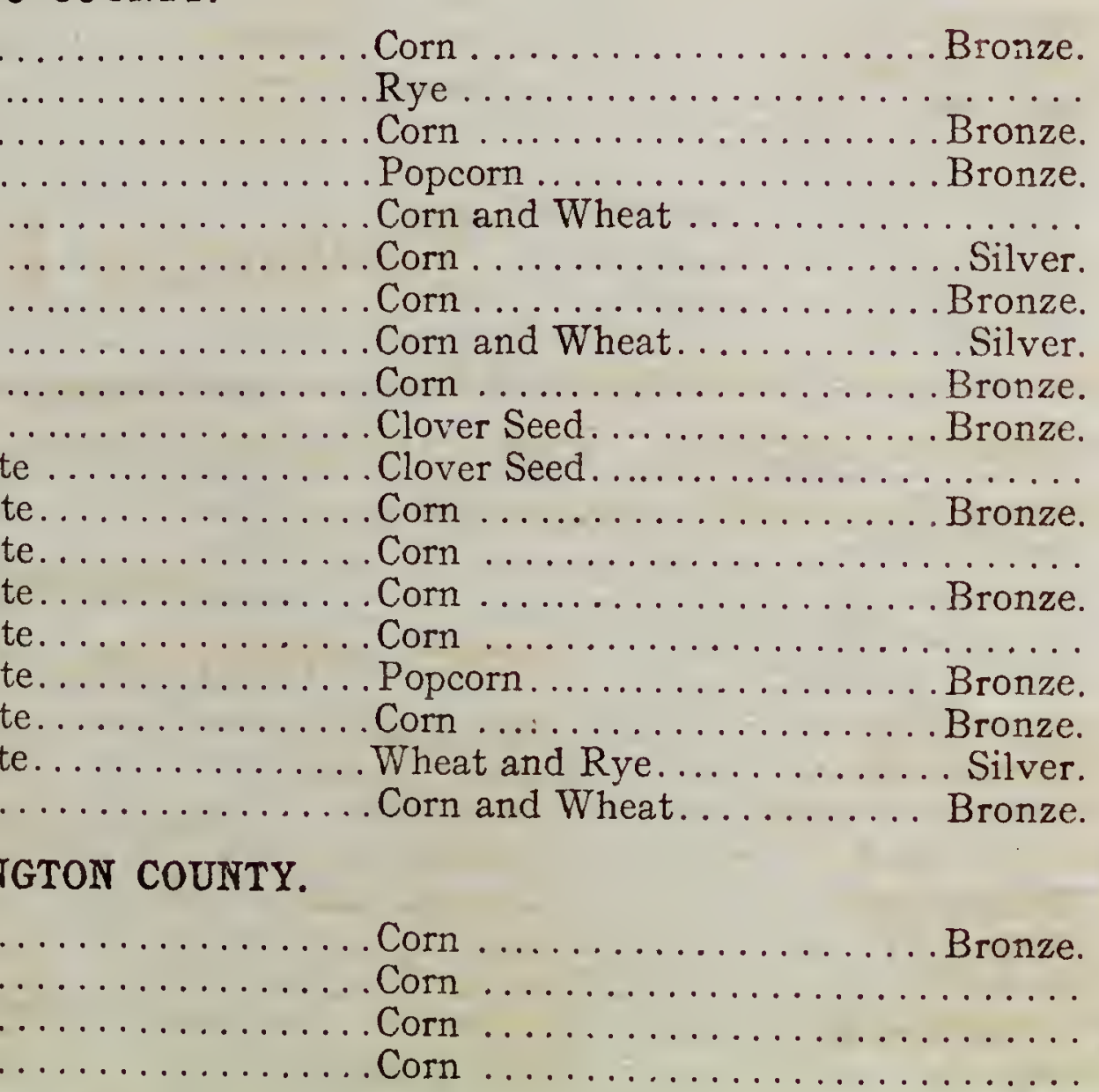

\section{WASHINGTON COUNTY.}

Grimes, J. P. . . . . . . . . . . . . . . Salem

Morris, Robert ................... Salem

Salem

Corn .................. Bronze.

Wheat.................. Bronze.

Oats. .

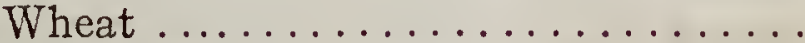

Wheat................ Bronze.

Wheat.................Bronze

Spurgeon, A. N.

Salem

Corn 
WELLS COUNTY.

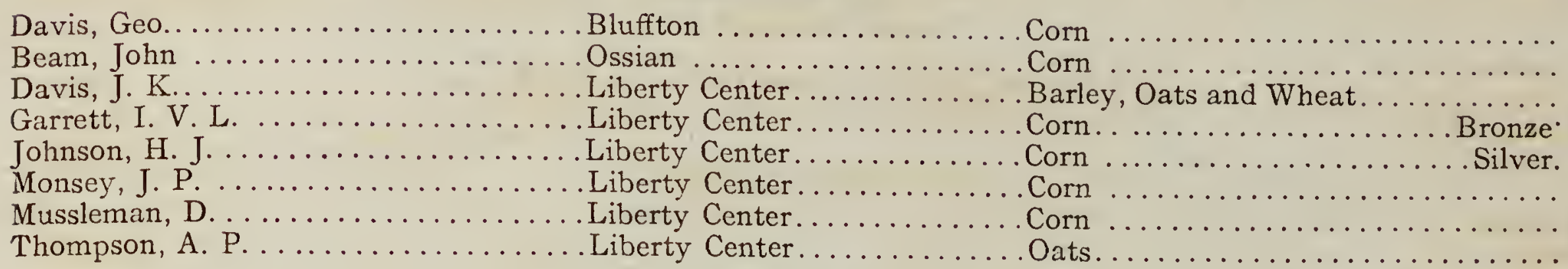

WHITE COUNTY.

Myers, S. W. Monticello

Booker, P. J

Monticello.

Corn

Bronze.

Clerget, Paul

Buffalo

Corn

Loe, Bert

Monon...

Corn

Davis, John

Brookston

Corn

Kemp, Leonard

Brookston.

Corn

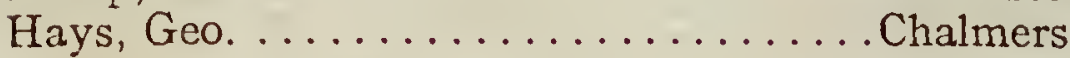

Corn $\ldots \ldots \ldots \ldots \ldots \ldots \ldots$ Bronze.

\section{Tobacco Exhibit.}

In addition to the awards made on the above individual exhibits, the State of Indiana was awarded a silver medal for a collection of tobacco. These exhibits were furnished by two counties, Switzerland and Spencer, and the growers furnishing the exhibits were as follows:

\section{GROUP 81.}

\section{Slucy Brothers} McCreary, Omer Mackensie, Clarence Traflet, Sam T. Bandley, Oscar Loring, I. P.

Turner, W. Brockslanger, J. P. Brown, A.

\section{COUNTY: SWITZERLAND; POSTOFFICE: VEVAY.}

Bretz, Joseph Patton, Joshua

Adams, D. D.

Browning, C.

Anderson, Geo.

Norris, A. J.

McKay, Jos.

Brendley, A.

Patton, Jos.
Mackensie, C. M.

Allen, D.

Dreamon, W. H.

Butler, Geo.

Turner, M. F.

Curry, Elmer

Smith, R. N.

Tilly, John

Webster, Perry
Bales, $\mathrm{H}$.

Heady, F. B.

Allen, D.

Slack, Fred.

MacFarland, J. G.

Roman, John

Camberland, M. R.

Brett, Jas.

Readt, W. C. 
Heady, Thos.

Wiseman, $\mathrm{S}$.

Mackensie, C. W.

Connen, Jos
Danner, S. L.

Bailes, Harry

Lance, Al.
Levis, Lon

Worshmouth, H. C.

Turner, Elmer

COUNTY: SPENCER; POSTOFFICE: ROCKPORT.

Bretz, J. P. Grimes, Prince

Haines, Jos.

\section{Horticultural Exhibit}

The State Horticultural exhibit was located near the main entrance of the Horticultural Palace, and consisted of seven large tables and other furniture occupying 1200 square feet. The exhibits were displayed on plates placed on the tables.

The horticultural exhibit was under the jurisdiction of the Committee on Agriculture. This committee appointed a sub-committee which had charge of the detail work of assembling, installing and caring for the same during the Fair. This sub-committee was composed of W. B. Flick, Lawrence; Sylvester Johnson, Irvington; and John C. Grossman, Wolcottville. The most important purpose of the Commission in making a display of the horticultural products of the state was to demonstrate in the most practical way the possibilities of future development in the cultivation of fruits, vegetables, nuts, etc. The Committee interested the fruit growers of the state by correspondence and by personally calling upon them during the year 1903, and this work resulted in a good display of fruit from the crop of that year. This was placed in cold storage at Indianapolis until April 1, 1904, when it was shipped to St. Louis, placed in cold storage at the Fair grounds, and was drawn upon from time to time as required to supply the exhibit booth. The 1904 crop took the place of the 1903 crop late in the season, it being shipped in by the fruit growers of the state to the Committee and placed in the exhibit as needed. Notwithstanding the fact that 1903 and 1904 were both poor fruit years for Indiana fruit growers, the Indiana exhibit ranked with the best and received more awards than that of any other state. Great credit is due to the Committee and to those in charge who so earnestly and faithfully performed their duties, and too much credit cannot be given to the fruit growers who so liberally contributed and assisted in making the affair a complete success. About three hundred varieties of flowers, pawpaws, per pears, thirty of pearhes, one hundred of plums and many varieties of grapes, berries, nuts, watermelons, besides curious, mast, apricots, lemons, oranges, figs (house plants), cantaloupes, muskmelons and was more extensive than that of any other growths of trees, plants and fruits, were shown. The range of varieties second to none. The Committee published a bur fruit exhibit demonstrated qualities of flavor, color and keeping uted 10,000 copies. The state was awarded a gold medal on "Facts About Fruit Culture in Indiana" and distribhundred and twenty awards were given to exhibits grown this exhibit as a collective exhibit of fruit, and one societies and placed in the state exhibit. 


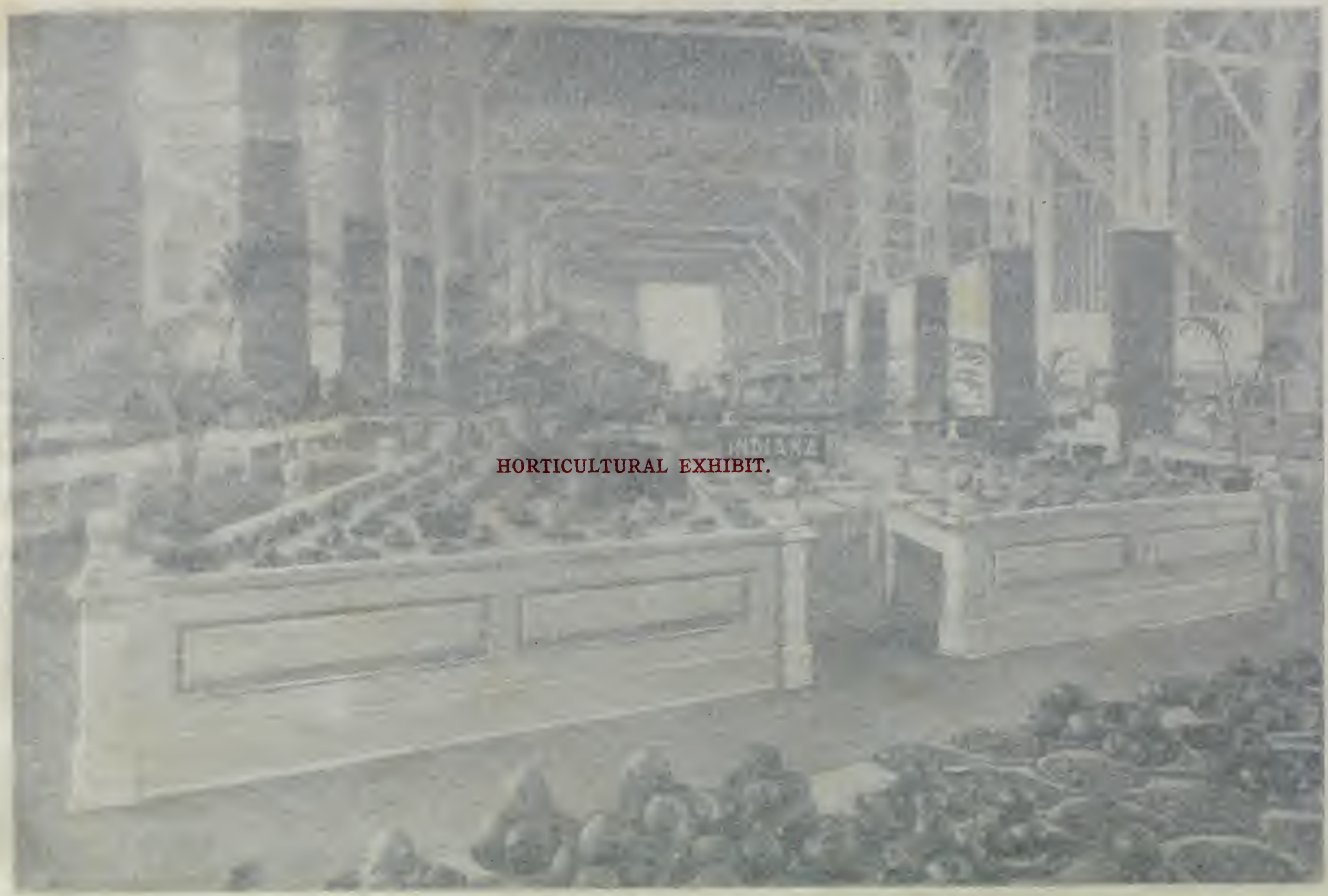




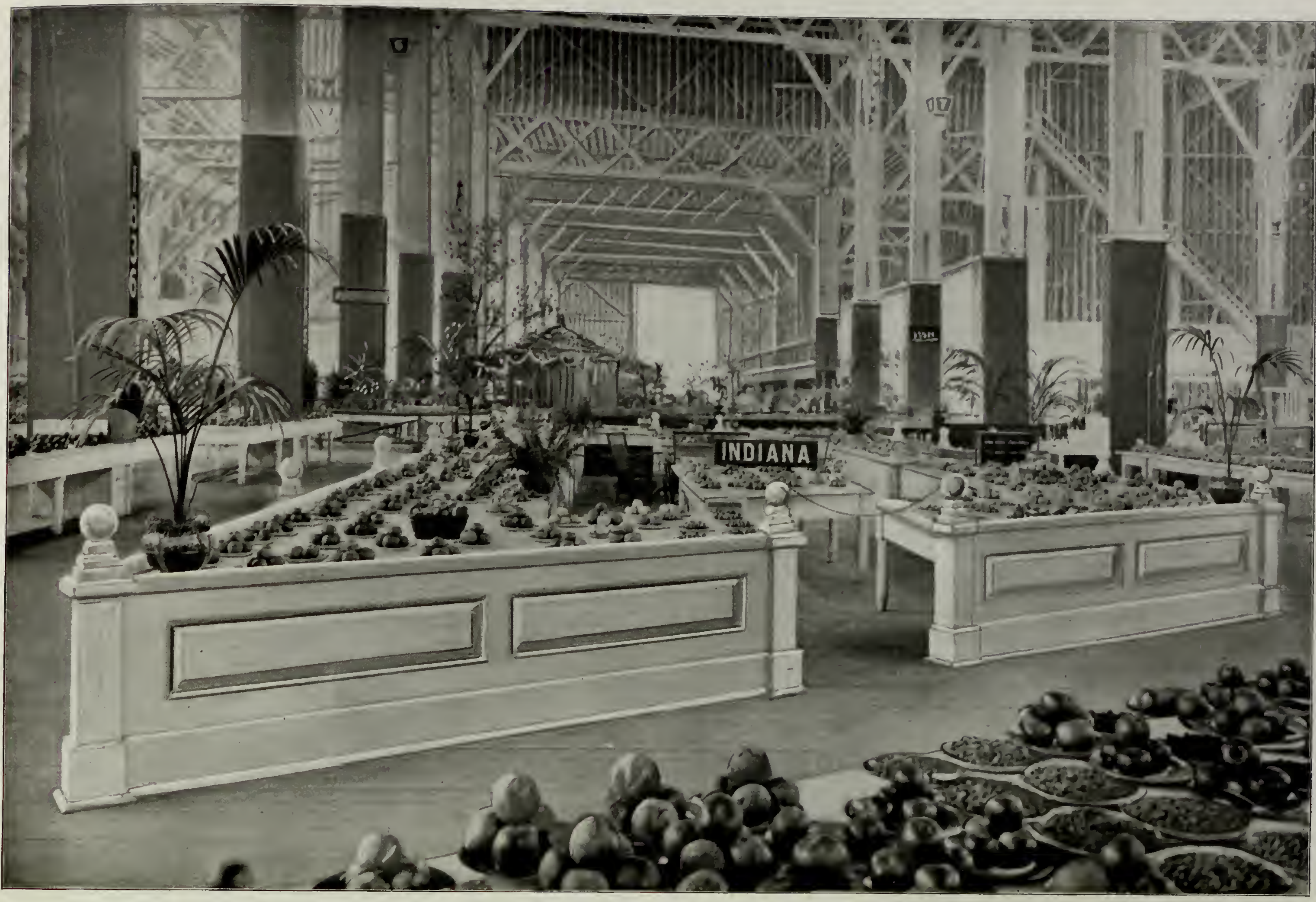


Herewith are appended the names and addresses of those who contributed to the cold storage stock in 1903:

Andrews, W. H.; Wolcottville; Apples. Augustine, W.; Grandview; Apples. Beck, R. L.; Connersville; Apples. Bogue, A. H.; Lagrange; Apples.

Burton, J. A.; Mitchell; Apples.

Bordeaugh, G. W.; Grandview; Apples. Bricker, B. W.; Shipshewana; Apples.

Broughton, Wm.; Wolcottville A Apples. Blinkness, Sam1.; Grandview; Apples.

Burton, J. A.; Mitchell; Apples and Pears. Bradley, C. P.; South Bend; Apples. Bradley, Mrs. May; Elwood; Lemons. Bellville, John; Grandview; Apples. Bowman, Mott; Lagrange; Apples.

Chrystler, Wm.; Shipshewana; Apples.

Dougherty, D.; Richmond; Apples. Davis, E. B.; Danville; Apples.

Ditzay, Fred; Craig; Apples.

Dawson, C. C.; Grandview; Apples.

Dean, W. H.; Grandview; Apples.

Emerick, Mrs. J. W.; Kendallville; Apples.

Eaton, Gertie; Shipshewana; Apples.

Eaton, Ed.; Lagrange; Apples.

Eaton, A. H.; Lagrange; Apples.

Eikhoff, Ed.; Wanamaker; Apples.

England, J. S.; Tobinsport; Apples.

Flick, W. B.; Lawrence; Apples.

Farnaman, Mrs. Lucy; South Bend; Apples.

Garrison, Henry; Oakland City; Apples.

Grossman, Miss Mary; Wolcottville; Apples.

Grossman, J. C.; Wolcottville; Apples.

Garmire, H. B.; Lagrange; Apples.

Henwood, John S.; Centerville; Apples.

Henry, H. W.; Laporte; Apples.

Henby, Jesse; Cambridge City; Apples.

Hazelett, S. A.; Greencastle; Apples.

Haster, H. W.; Halls Corner; Apples and Pears

Harms, Chas.; Richmond; Apples.

Hammond, C. S.; Rockport; Apples.

Hizer, Dock; Grandview; Apples.

Harah, Chas.; Wolcottville; Apples and Pears.
Jeffrey, J. C.; Grandview; Apples.

Knaub, Ben; North Vernon; Apples.

Kramer, A.; Cambridge City; Apples.

Klinkner, Wm.; Grandview; Apples.

King, Chris.; Rushville: Apples.

Kimmel, Orlando; Kimmel; Apples.

Kistner, J. P.; Laconia; Apples.

Laughrey, David; Lagrange; Apples.

Latta, G. A. ; Lagrange; Apples.

Low, J. W.; Topeka; Apples.

Lafuse, W. H.; Liberty; Apples.

Lampman, O. A.; Topeka; Apples.

Milhouse, J. J.; Valley Mills, Pears.

Mosby, R. C. ; Grand View; Apples.

Sanitorium, Kneipp; Rome City; Apples.

McMahan, E.; Richmond; Apples.

Newby, T. T.; Carthage; Apples, Pears and Nuts,

Newman, R. H.; Shipshewana; Apples.

Osborn, E.; Economy; Apples.

Price, A. H.; Wolcottville; Apples.

Ratliff, W. S.; Richmond; Apples.

Robinson, W. B.; Vincennes; Apples.

Royer, E. E.; Wolcottville; Apples.

Rerick, J. A.; Grandview; Apples.

Swift, Evan; Franklin; Apples.

Stemple, Milton; Indianapolis; Apples.

Stanley, Mrs. Rhoda; Carmel; Apples.

Swain, H. H.; South Bend; Apples.

Stout, H. M.; Trafalgar; Apples.

Sowers, D. L.; Rome City; Apples.

Turton, J. W.; Grandview; Apples.

Tavelbee, Wm.; Wolcottville; Apples.

Thomas, W. D.; Connersville; Apples.

Tilson, John; Franklin; Apples.

Voss, J. M.; Richmond; Apples.

Wintner, J. P.; Grandview; Apples.

Whitley \& Son; Cambridge City; Apples.

Williams, Q. T. S.; Knightstown; Apples.

Woodworth, Fayette; Lagrange; Apples.

Zion, J. M.; Clark's Hill; Apples.

And the following in 1904: 
Albertson \& Hobbs; Bridgeport; Apples, Pears, Nuts, and Quinces.

Athey, L. L.; Madison; Apples and Dewberries.

Augustine, N.; South Bend; Apples.

Armentrout, Wm.; Frankfort; Apples.

Burton, Geo.; Leipsig; Apples.

Beck, R. L.; Liberty; Apples, Pears, Peaches and Plums.

Beard, M. C.; Edwardsville; Apples, Pears and Plums.

Bieler, J. C.; New Albany; Apples.

Blue Bros.; Indianapolis; Berries and Plums.

Bruce, W. W.; Bartholomew County; Nuts.

Baughman, Lew; Danville; Crabapples.

Burgess, John L.; Moberly; Apples, Pears and Peaches.

Belleville, John; Grandview; Apple:.

Bradley, C. P.; South Bend; Apples.

Burton, Joe A.; Mitchell; Apples.

County Farm; Clinton Co., Frankfort; Apples.

Chamberlain, John V.; Bloomington; Apples and Pawpaws.

Campbell, Geo.; Bloomington; Pears and Plums.

Chamberlain, R. H.; Bloomington; Apples.

Daugherty, Deolin; Cambridge City; Apples.

Devilbiss, W. F.; Fort Wayne; Apples and Pears.

Davis, Mrs. B. A.; Laporte; Apples, Pears, Peaches, Plums, Cherries and other fruit.

Farnsley, Capt.; Locust Point; Pears and Peaches.

Farnaman, Lucy; South Bend; Apples.

Garrison, Henry; Oakland City; Apples.

Garritson, Amos; Pendleton; Plums and Raspberries.

Haines, Chas.; Richmond; Apples.

Hale, H. J.; Indianapolis; Apples and Pears.

Hunter, Wm.; Princeton; Watermelon.s

Hain, H. E.; Granger; Apples, Pears and Plums.

Henshaw, J. J.; Evansville; Peaches.

Hazelett, Samuel A.; Greencastle; Apples.

Hepner, W. J.; Topeka; Apples.

Hadley, Dr.; Danville; Apples.

Henwood, J. S.; Centerville; Apples.

Hitz, Geo.; Indianapolis; Apples and Grapes.

Hobbs, Howard; Salem; Plums.

Huser, Doc; Grandview; Apples.

Hammond, C. L.; Oakland City; Apples.

Jeffreys, J. M.; Danville; Plums.
Kline, Mrs. Oliver; Huntington; Plums.

King, Chris.; Rushville; Apples, Pears and Plums. Knaub, Ben; North Vernon; Apples, Pears, Plums and Peaches.

La Loma Jarden Exp. Station, Clark's Hill; Apples and Pears.

Lindley, C. W.; Salem; Pears.

Lafuse, Homer; Liberty; Apples.

Lampman, O. A.; Topeka; Apples.

Low, J. W. Topeka; Apples.

McHahan, Elijah; Richmond; Apples.

McGloran, Chas. ; Sunshine; Apples, Pears and Peaches

Marsh, J. W. ; Muncie; Cucumbers.

McCallister, Oscar L.; Mount Vernon; Pecans and Hickory Nuts.

Marion Co. Horticulture Society; Indianapolis; Nuts.

Milhous, J. J.; Valley Mills; Plums.

Maish, D. F.; Frankfort; Grapes.

Newby, Thos. T.; Carthage; Apples, Pears, Peaches,

Plums, Cherries, Berries, Pawpaws, Persimmons,

Chestnuts, Quinces, Apricots, Grapes and Fruit of the Rose.

Osborne, Elin; Economy; Apples.

Phillips, J. W.; Princeton; Apples.

Purdue University; Lafayette; Apples.

Potter, Frank; Valley City; Apples and Pears.

Reddick, Lewis; Carthage; Plums.

Robison, G. T.; Greenwood; Apples, Pears and Peaches.

Resh, John M.; New Middleton; Grapes.

Robinson, W. B.; Vincennes; Apples.

Royer, Chas.; Valentine; Pears.

Ritterskamp, W. J.; Princeton; Apples and Peaches.

Spencer, E. M.; Mount Vernon; Pecans.

St. Joseph Co. Hort. Society; South Bend; Apples.

Swain, H. H.; South Bend; Pears and Grapes.

Shoemaker, A. W.; Daleville; Apples, Pears and Plums

Stoker \& Thomas; Sunshine; Apples and Pears.

Stevens, John A.; Liberty; Apples.

Troop, Prof. Jas.; Lafayette; Apples.

Thompson, D. A.; Frankfort; Pears.

Thompson, J. W.; Danville; Pawpaws.

Tufts, Elmer G.; Aurora; Apples, Pears, Grapes,

Tomatoes and Cucumbers.

Vannice, H. N.; Danville; Apples and Plums.

Voss, J. M. ; Richmond; Apples. 
White, A. W.; Mooreland; Plums.

Wehry, Henry; North Vernon; Plums.

Williams, T. S.; Knightstown; Apples and Pears.

Yeager, Henry H.; Princeton; Apples and Pears.

Zion, Jas. M.; Clark's Hill; Apples and Pears.

Zion, Ralph; Clark's Hill; Pears.

Zion, Ruby; Clark's Hill; Apples.

Halbert, Anna; Wolcottville; Apples.

Dallas, James; Wolcottville; Apples.

Hooke, George; Wolcottville; Apples.

Andrews, W. H.; Wolcottville; Plums.

Simmonds, Chas.; Wolcottville; Pears.

Kaieger, Mollie; Wolcottville; Pears and Plums.

Eaton, Gertrude; Lagrange; Apples.

Charles, John; Lagrange; Apples.

Lagrange Hort. Society; Lagrange; Apples, Pears and Pawpaws.

Miller, Mrs. Jacob; Lagrange; Seedling Oranges.

Chegston, J. D.; Lagrange; Plums.

Harmon, A. J.; Orleans; Crabapples.

Turley, A. J.; Orleans; Apples.

Wright, G. F.; Orleans; Apples.

Burton, G. W.; Orleans; Apples.

Hardman, Oscar; Orleans; Apples.

Waddell, Amos; Topeka; Apples.

Greenwoll, Henry; Topeka; Apples and Pears.

Wample, Prixley; Topeka; Apples.

Exhibitors in the Department of Horticulture, Group 107, received awards as follows:

Name.

Residence.

Indiana, State of

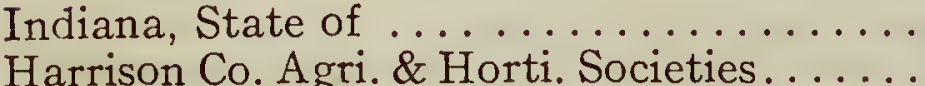

Lagrange Co. Horti. Society

Marion Co. Agri. \& Horti. Societies............

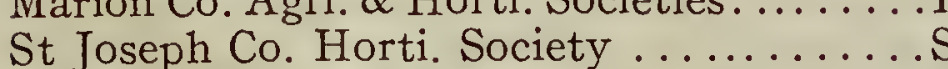

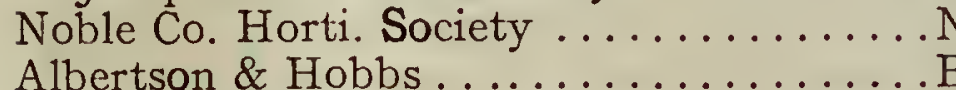

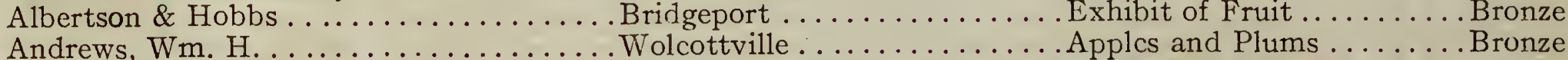

Athey, L. L. . . . . . Silver.

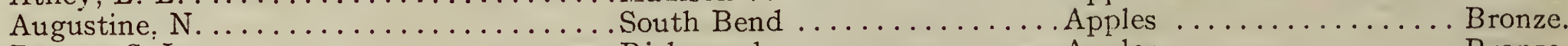

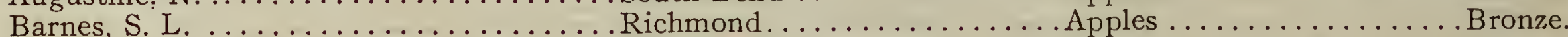

Beard, M. C. .................... Edwardsville ............. Plums............... Silver

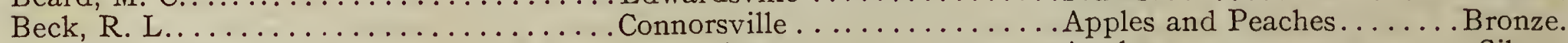

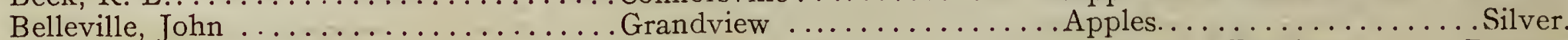

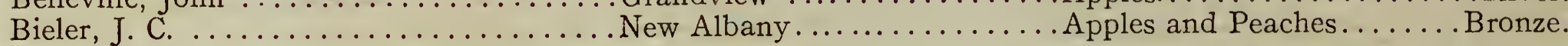


Blue Bros.

Bogue, A. H

Bradley, C. P.

Brewest, A. W

Bricker, S. L.

Burgess, John S.

Burton, Geo. W.

Burton, J. A....

Campbell, Geo.

Chamberlain, John V.

Charles, John J

Chrysler, Wm. .

Cornelius, Henry

Corydnn Fair Ass'n

County Farm

Cramer, Henry.

Cummings, C. W.

Davis, Mrs. B. A
DeVilbiss, W. F.

Dougherty, Deolin ...

Eaton, Ed.

Eaton, Mrs. Gertrude

Farnaman, Mrs. Lucy

Ferguson, L. E.

Flick, W. B.

Jos. Fields.

........

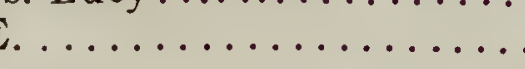

Garmire, Marion

Garretson, A \& Son .

Gonzon, Peter

Grossman, F. C.

Grossman, J. C.

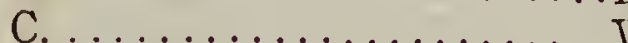

Grossman, Miss

Haines, Chas.

Hain, H. E.

Hardman, Oscar

Harman, A. T.

Harrah, Chas.

Henry, H. W

Henshaw, J. J.

Henwood, J.S.

Heffner, Wm. J

Hitz, G.

Huser, Doc

Huston, W. C.
Indianapolis

Lagrange ....

South Bend

Shipshewana

Bartholomew Co.

Moberly

.Orleans

. Mitchell....

Bloomington

Bloomington

Lagrange

Lagrange

Wolcottville

Corydon

Clinton Co.

Wolcottville

Indianapolis

Fort Wayne.

Cambridge City

Lagrange

Lagrange

South Bend

White Pigeon.

Lawrence

Lagrange

Lagrange

Pendleton .

Lagrange

Wolcottville.

Wolcottville

Richmond

Granger. .

Orleans

Orleans .

Wolcottville

Greencastle.

Laporte. ...

Evansville

Centerville

Topeka.

Indianapolis

Grandview

Rome City
Exhibit of Fruit.

Apples

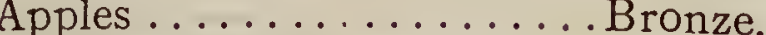

Exhibit of Fruit...........Bronze.

Apples ................ Bronze.

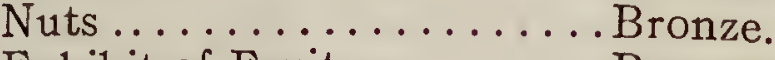

Exhibit of Fruit.......... Bronze.

Apples................... Silver.

Apples and Pears .......... Gold.

Pears and Plums .......... Bronze.

Apples and Pawpaws ...... Bronze.

. Apples................. Silver.

Apples ................. Bronze.

Apples . ................. Silver.

Apples and Pears..........Bronze.

Apples ................ Bronze.

Apples................ . Silver.

Apples ................. Bronze.

Exhibit of Fruit. .......... Silver.

Exhibit of Fruit ........... Silver.

Apples ............... Bronze.

Apples ............... Bronze.

Apples ................. Bronze.

Apples.................. Silver.

Apples ............... Bronze.

Exhibit of Fruit ........... Silver.

Apples ................... Bronze.

Apples ................ Bronze.

Raspberries and Plums .... Silver.

Pears .................. Bronze.

Apples ................ Bronze.

Exhibit of Fruit ........... Silver.

Exhibit of Fruit............. Bronze.

Apples .................Bronze

Exhibit of Fruit. .......... Bronze.

Apples ................. Bronze.

Crabapples ................ Bronze

Pears and Apples............. Silver.

Apples.................. Silver.

Exhibit of Fruit . .......... Silver.

Peaches................. Bronze

Apples..................... Silver.

Apples ................. Bronze

Apples ................ Bronze.

Apples ..................... Bronze.

Plums .............. Bronze. 


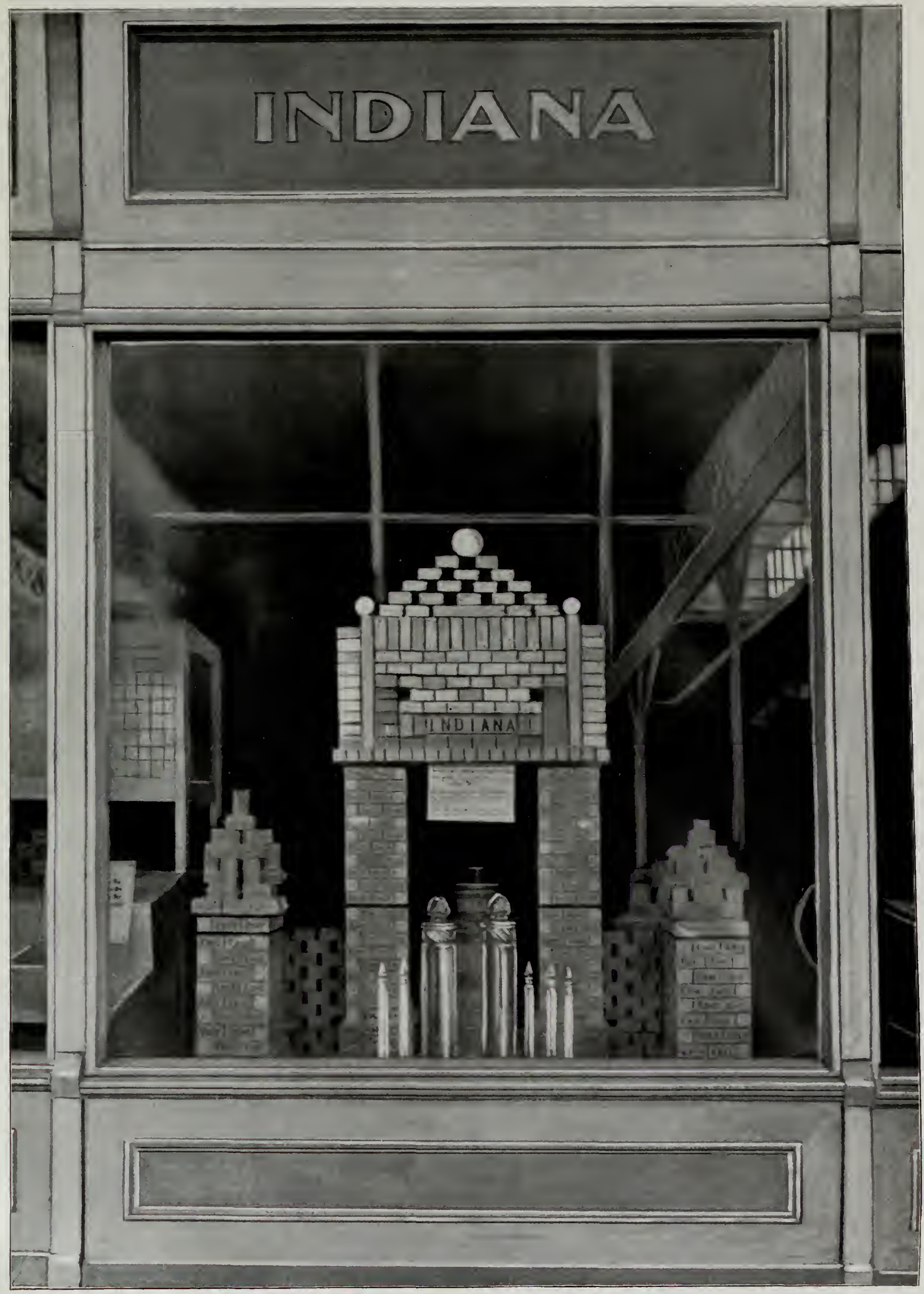




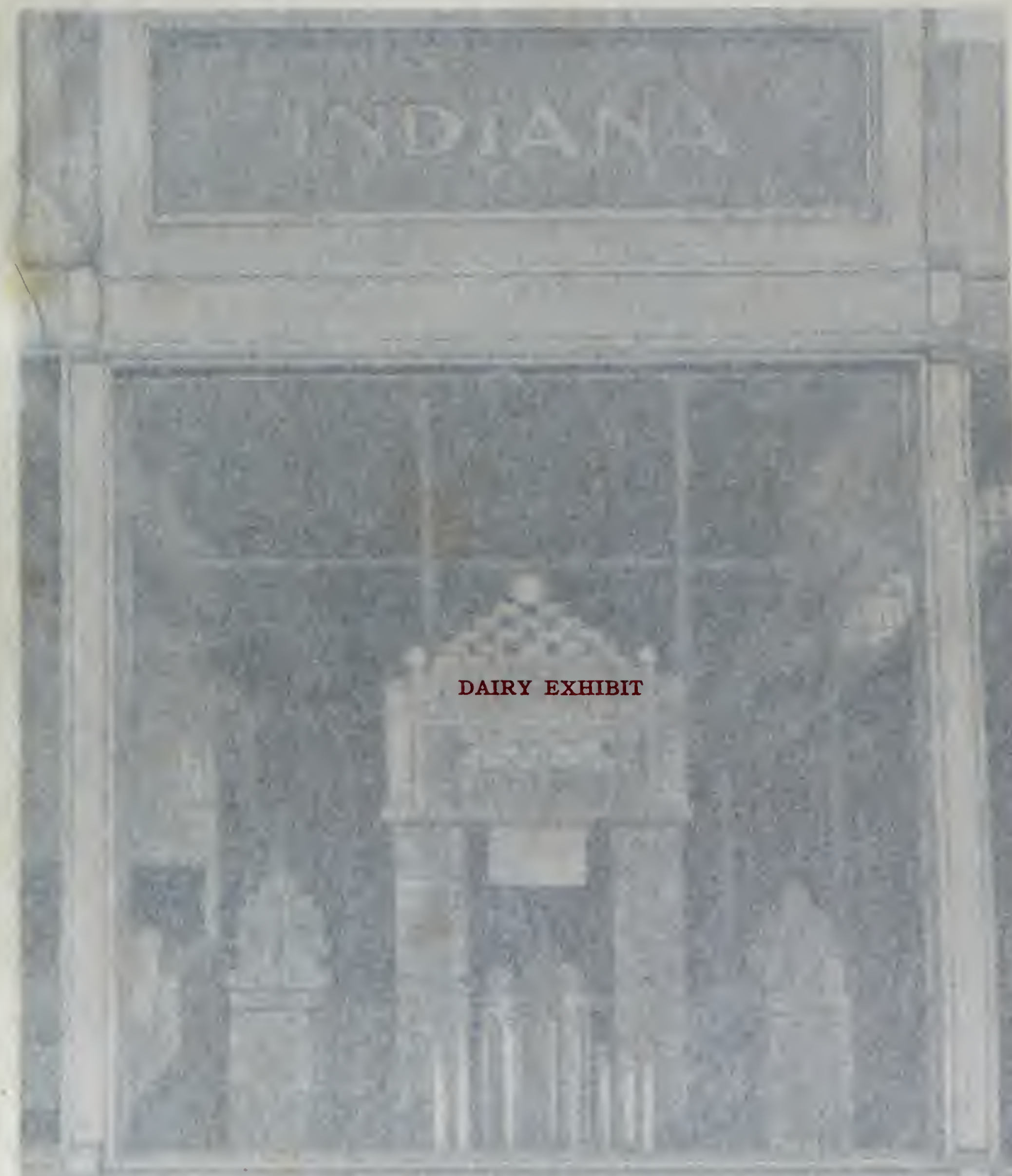


Jeffrey, J. C.

Grandview

Kaieger, Mrs. Mollie...............Wolcottville .

Apples

Bronze.

Kimmel, J. C.

Kimmel.

Pears and Plums

Bronze.

King, Chris.

Rushville

Apples

Bronze.

Klinker, Wm.

South Bend .................... Silver. Apples

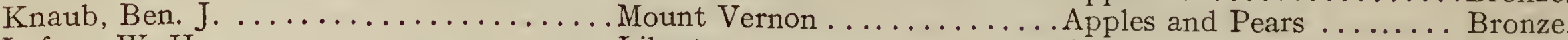

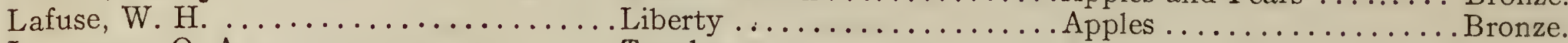

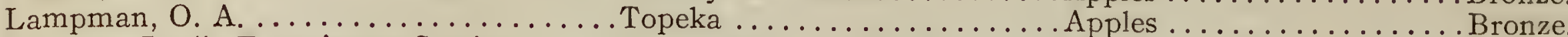

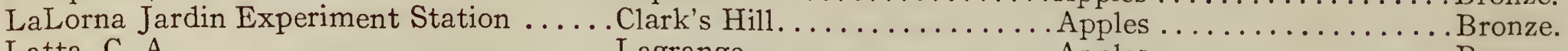

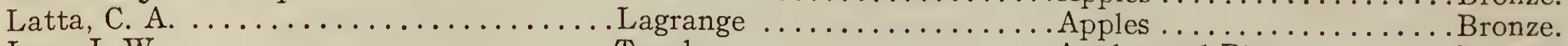

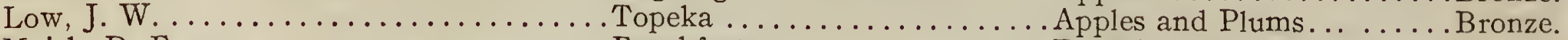

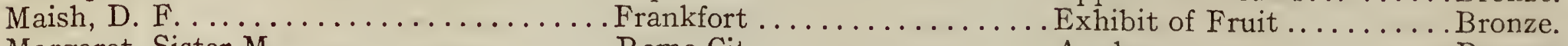

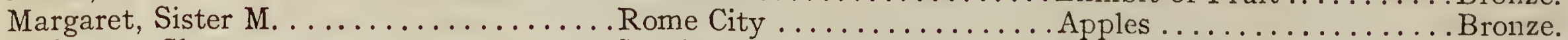

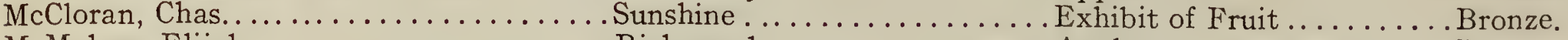

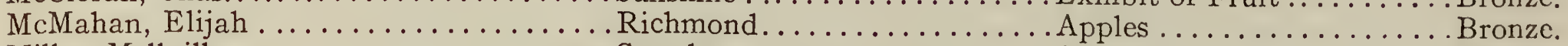

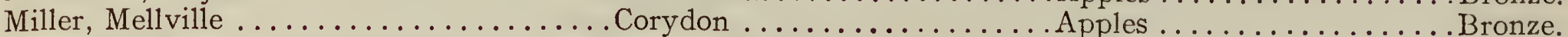

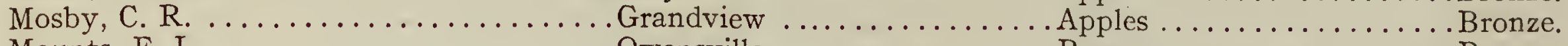

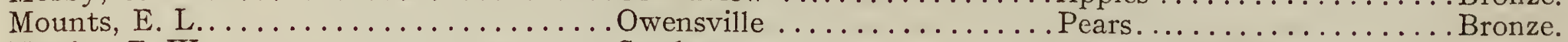

Newby, T. W. ................. Carthage .............. Exhibit of Fruit .......... Gold.

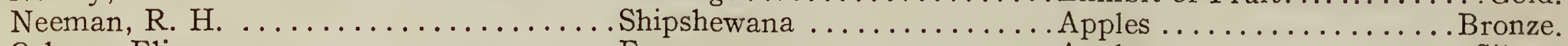

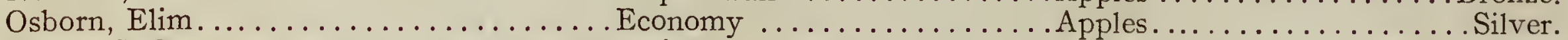

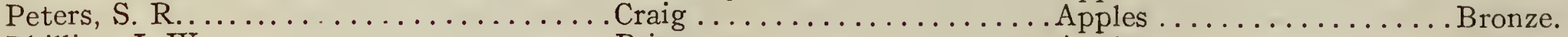

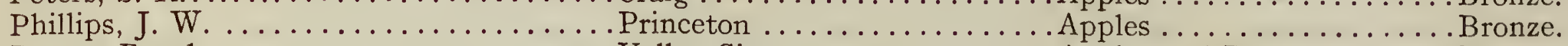

Potter, Frank................... Valley City..............Apples and Pears..........Bronze.

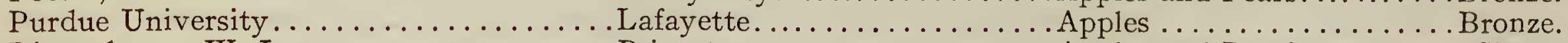

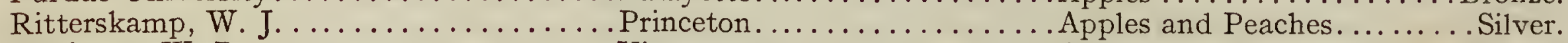

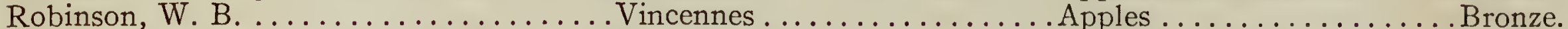

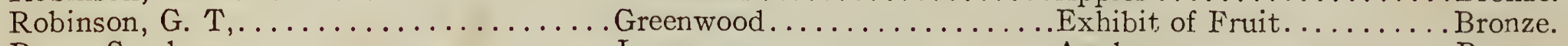

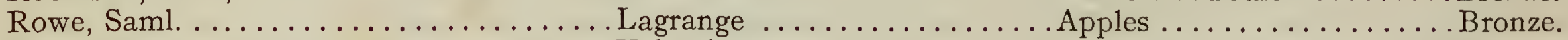

Royer, Chas...................Valentine ..............Pears ............... Bronze.

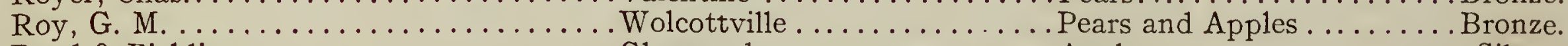

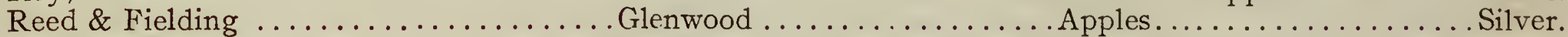

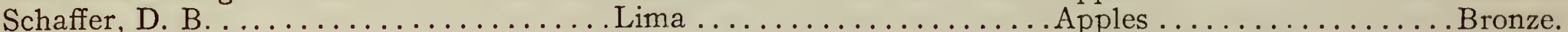

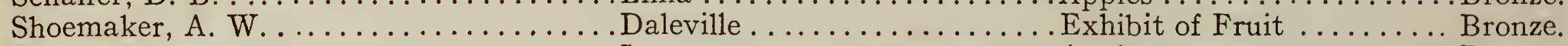

Snyder, Elmer.....................Lagrange ...............Apples . . . . . . ........ Bronze.

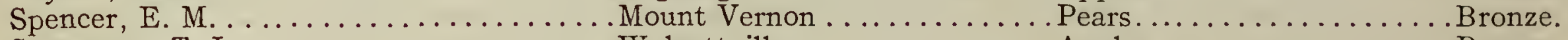

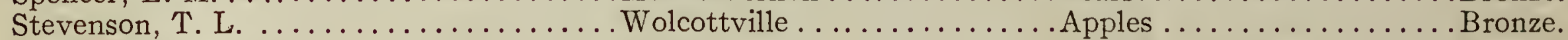

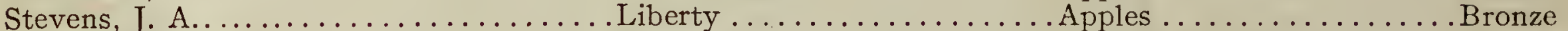

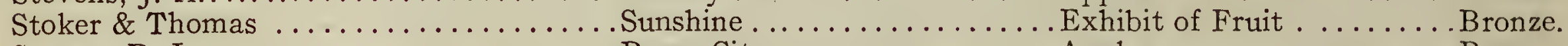

Sowers, D. L. . . . . . . . . . . . . . . Rome City ..............Apples . . . . . . . . . . Bronze.

Swain, H. H. .................. South Bend ............. Pears and Grapes ......... Silver.

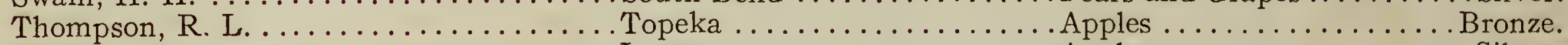

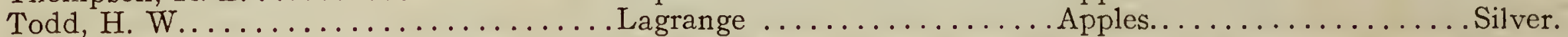

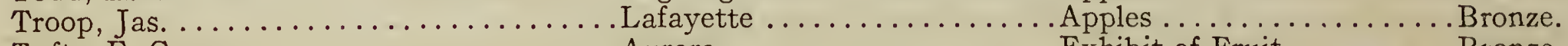

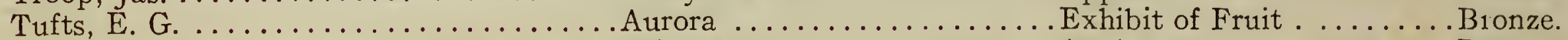

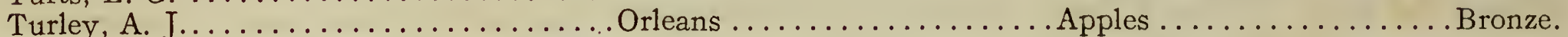




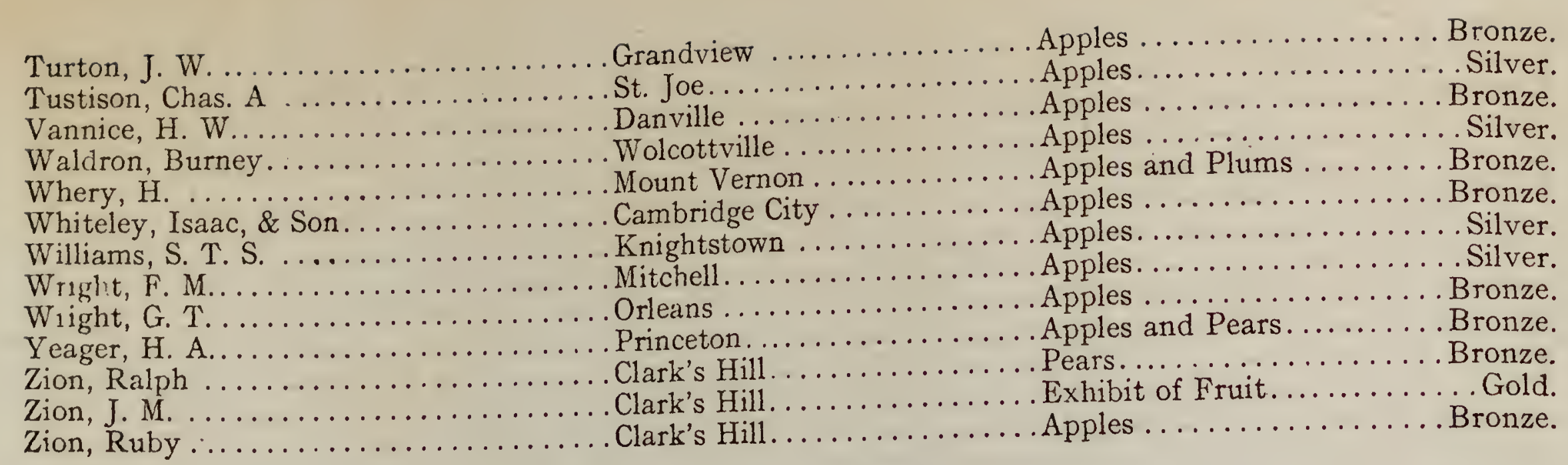

\section{Dairy Exhibit}

The Dairy Exhibit occupied one section, having glass frontage of eight feet in the large refrigerator in the Agriculture Building. It consisted of butter in commercial packages, tubs and prints, presenting a pleasing variety in contrast with the moulded figures of other states. The chief feature was a structure consisting of four columns, two of which supported a superstructure and each represented a year's production from a high grade cow. SurmountIng these were prints bearing the wrappers of those creameries which put their butter in pound prints.

In the foreground and connected with the tall column by a balustrade of pound prints, were two short columns each representing a year's production by the average cow of the state, as shown by the last census. The tall column showed three hundred and three pounds, of which one hundred and sixty-four pounds sold at market price, were required to pay for the feed consumed during one year, while the short columns showed one hundred and sixtyseven pounds, of which one hundred and fifty-eight pounds were required for feed consumed, presenting to the eye in a striking manner the difference in yield and profit between good cows and common cows. Many of the latter are kept at an actual loss.

Between the tall columns was a pyramid of different sized tubs, so placed as to expose surface of the butter. In the foreground was shown print butter cut up and arranged in forms of different sizes for serving on the table. The floor and approach to the platform on which the columns rested, were covered with butter in pound and halfpound prints. The background was outlined by a border composed of half-pound prints arranged in geometric pattern.

In general, the exhibit presented butter in various marketable forms and packages, rather than moulded or sculptured forms, which require the skill of the sculptor rather than the dairyman. It was arranged in a manner to convey to the observer four important facts: First, the relative yield and cost of production; second, the difference in profit between good cows and the common cows of the state; and third, the economy of feeding skim milk 


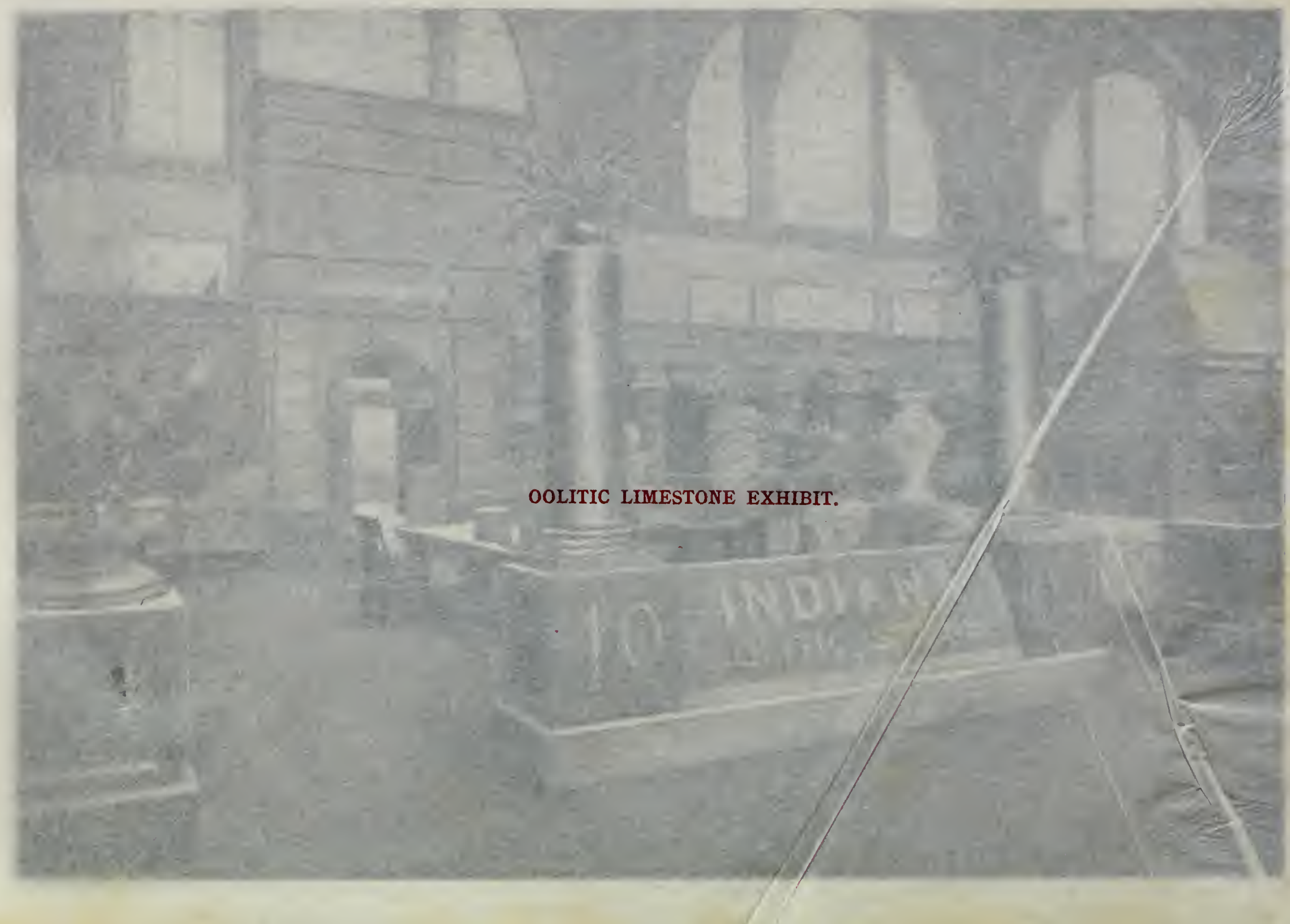




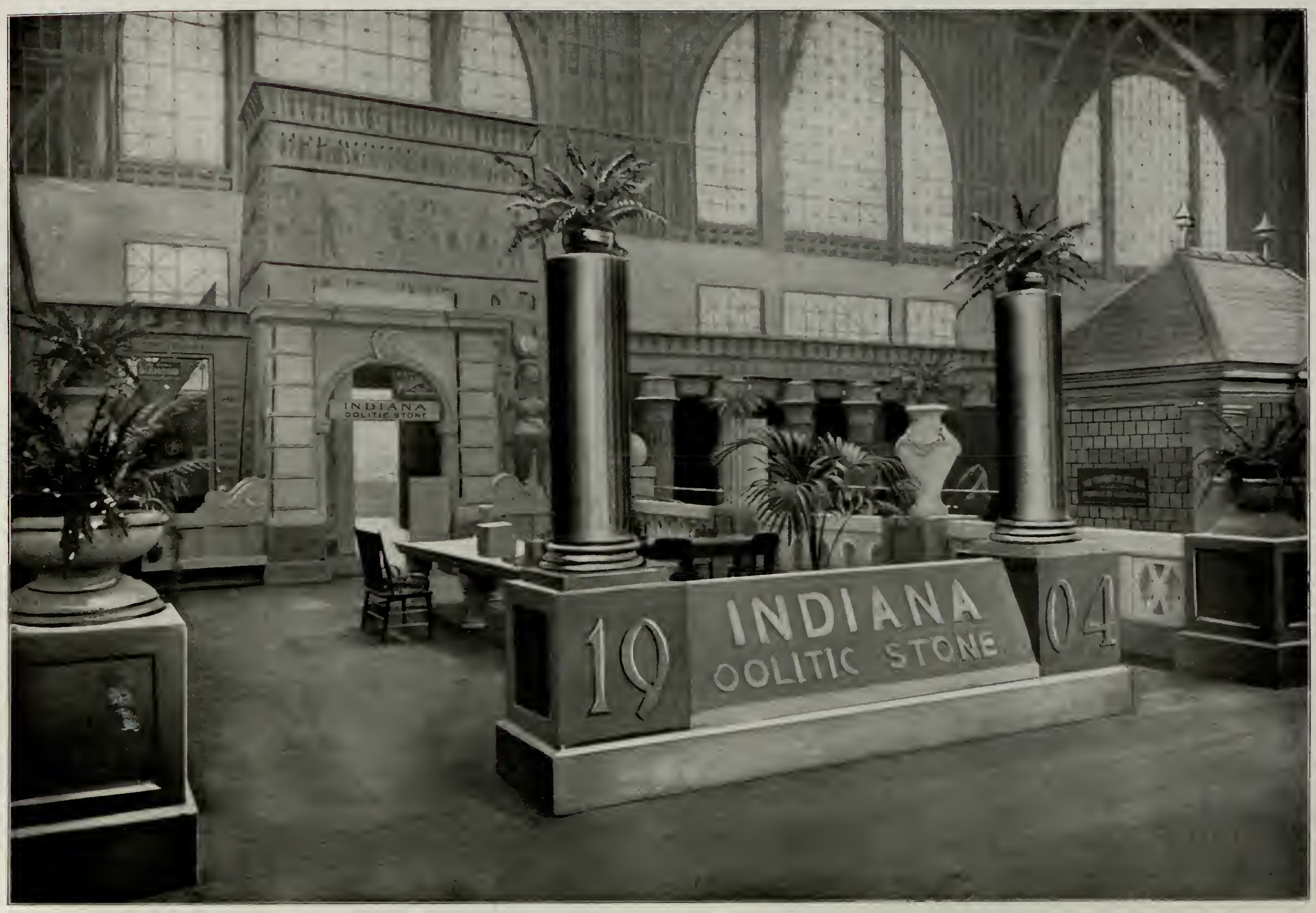


plus vegetable fat instead of whole milk containing high priced butter fat; fourth, how attractive marketable forms of packing butter lend themselves to tasteful shapes for serving on the table.

The exhibit was planned and installed by Professor H. E. Van Norman, head of the Dairy Department of Purdue University. Butter was contributed by the New Carlisle Creamery, New Carlisle, Ind., Schosser Bros., Oak Grove Creamery, Plymouth, Ind., and Purdue University Creamery, Lafayette, Ind.

The above firms, together with Avilla, Carlisle, Mondarim Meadows, Fort Wayne, Ind., Blue Grass Creamery Co., Churubusco, Millgrove Creamery at Orland, contributed butter wrappers.

In the cheese case on the opposite side of the aisle from the butter, were Young America, Twin and Full Cream Cheddar Cheese from Boyd \& Drischell of Cambridge City, Ind., and G. P. Swan, New Washington, Ind.

In the space adjoining the butter case, was a case containing photographs of a number of prominent dairies and herds in the state. There were also some photographs in Indiana's General Agricultural Exhibit.

The following prizes were awarded in this department:

\section{GROUP 85.}

Name.

Residence.

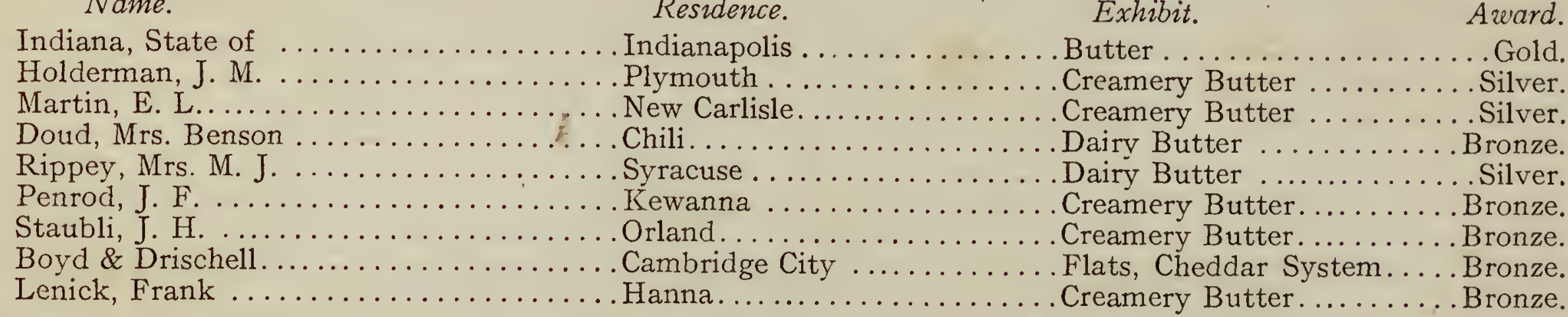

\section{Building Stone}

This exhibit was located in section 11 in the Palace of Mines and Metallurgy, assembled and installed under the direction of the Committee on Building Stone, and occupied floor space thirty by forty feet. Oolitic limestone of the best quality taken from the quarries of the Indiana stone field, and representing both the buff and blue building stone, were used in the exhibit, which included a terraced balustrade. From the aisle surrounding the entire exhibit space, there were two entrances to the enclosure, one through a large Renaissance arch, while the other entrance was supported by large solid columns and vases carved from stone. In the immediate front was a large stone panel, bearing the inscription "Indiana Oolitic Limestone." The terraced walls at the sides were made up of different designs, showing the various methods of treatment which the stone is capable of receiving. On each side of the arch there was a large rustic post and inside of these were pilasters supporting the arch, the wall being surmounted by a cornice and battlement. In the center of the space was a large stone table 
carved from a well selected piece of blue limestone, the size of the table being 16 feet by 4 feet 6 inches. Five individual companies furnished small but very attractive exhibits of carved stone. These exhibits were placed on the stone table, and attracted much attention.

One of the immediate purposes of the Commission in making the exhibit of oolitic limestone was to show the quality of the stone, both in color and the many ways in which it may be worked. The stone in this exhibit was quarried in the territory known as the Indiana district, which covers about sixty square miles, being largely located in Lawrence and Monroe counties. The Commission undertook to show that Indiana building stone is much more desirable than any other building stone now quarried in the United States, because it is soft when quarried and can be worked by machinery and with less expense. It may be planed and turned into balustrades, columns and bases the same as wood. Indiana oolitic limestone is thoroughly known and used throughout the country and is susceptible of receiving any kind of finish and the most delicate carving, and the exhibit was characteristic of all the possibilities of architectural embellishments. To those unfamiliar with its common use and treatment our exhibit offered excellent opportunities for the study of the various possible uses in all classes of stone work in this and other countries. This exhibit was awarded a grand prize, which was the only one awarded a stone exhibit at the Exposition.

The following companies made small but very attractive exhibits of oolitic lime stone, representing their companies, which were placed in the State Exhibit: Bedford Quarries Co., Mathers Stone Co., Hunter Valley Stone Co.. Star Stone Co., United States Stone Co., Romona Stone Co.

\section{Coal Exhibit}

The coal exhibit made by the state was the largest and most attractive exhibit of coal in the Palace of Mines and Metallurgy. It was assembled and installed under the direction of W. H. O'Brien, Chairman of the Committee on Mines and Mineral Products, the other two members of the Committee being Crawford Fairbanks and W. W. Stevens.

The exhibit represented a medixval fortress and tower,occupying space of $730 \mathrm{sq}$. ft. and was over $30 \mathrm{ft}$. in height. One of the principal characteristics of the fortress was the wall built of block coal in its natural state, 7 feet high, surmounted by a battlement. The entrance was in the center of the principal facade, at either side of which were monoliths of coal 2 feet square by 8 feet in height. The tower was built from the center of the fortress and was 15 feet in diameter at the base, and 30 feet high. This part of the exhibit was built of a fine quality of bituminous coal. The tower was illuminated by electric lights, giving to the whole a distinctively mediæval aspect. The exhibit was a faithful representation of an important product of the state. The coal exhibit of the state was awarded a gold medal. The unique design of the exhibit and the high quality of the coal used therein were appreciated by all. One hundred and thirty-six tons of coal were used in the exhibit. 


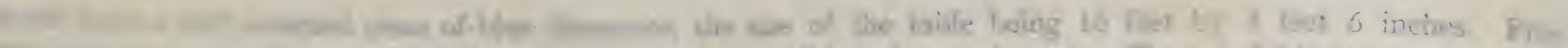
wh rast sur ve

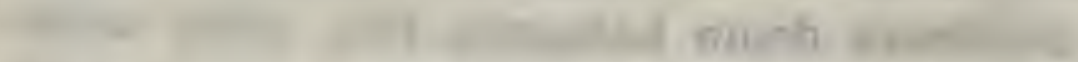

(4)

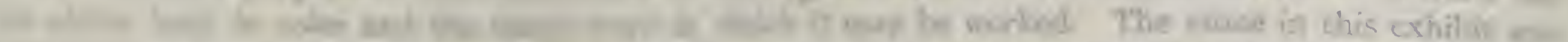

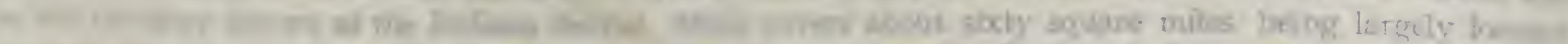

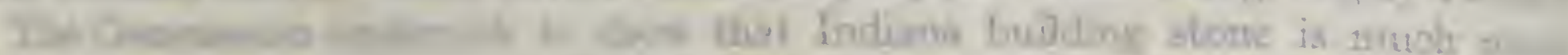

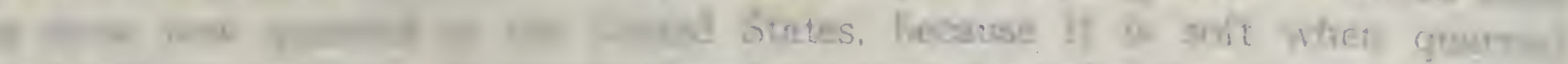
Q

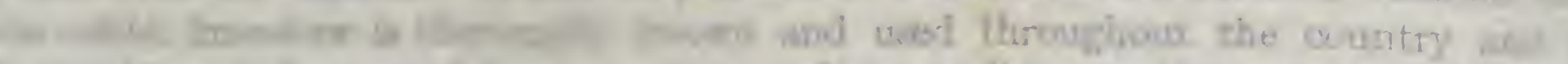

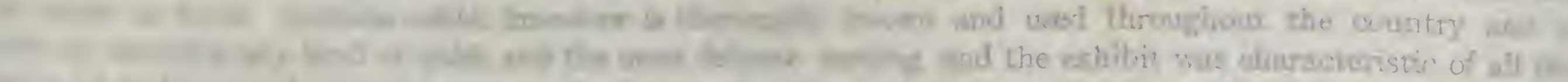

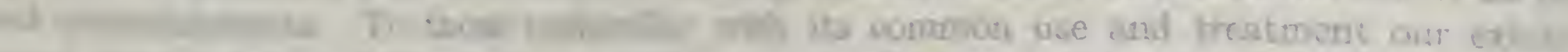
r

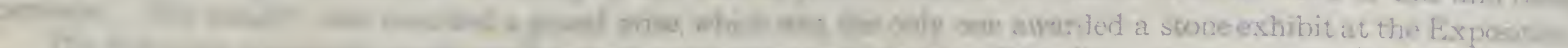
W

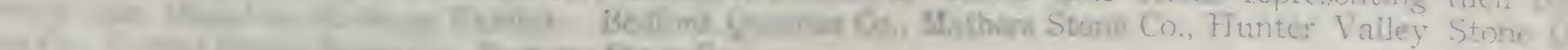
Dunasiner $\mathrm{C}$.

\section{Coal Exhibit}

\section{COAL EXHIBIT.}

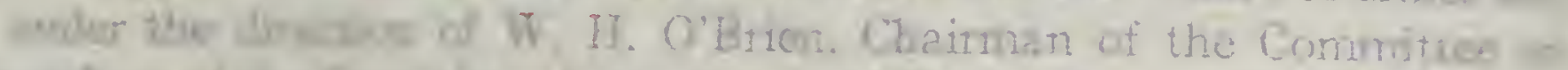

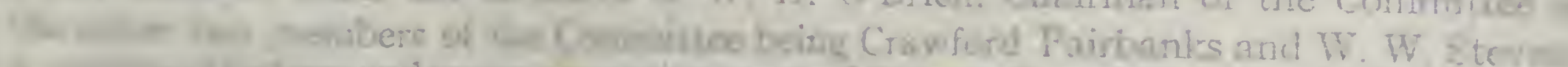

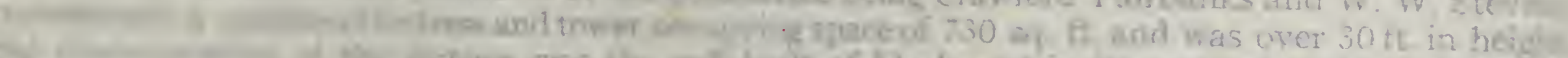
17 s.

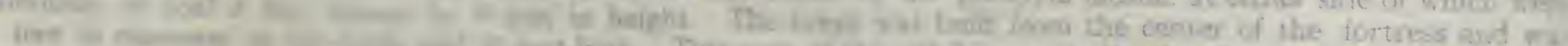
Th

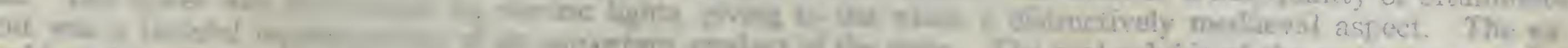

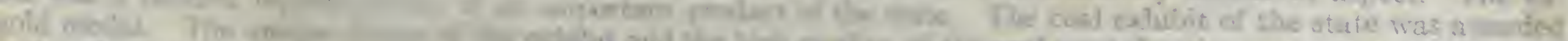

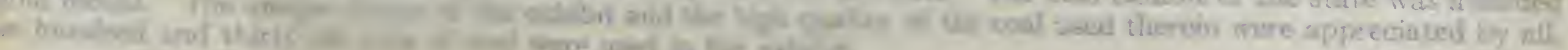




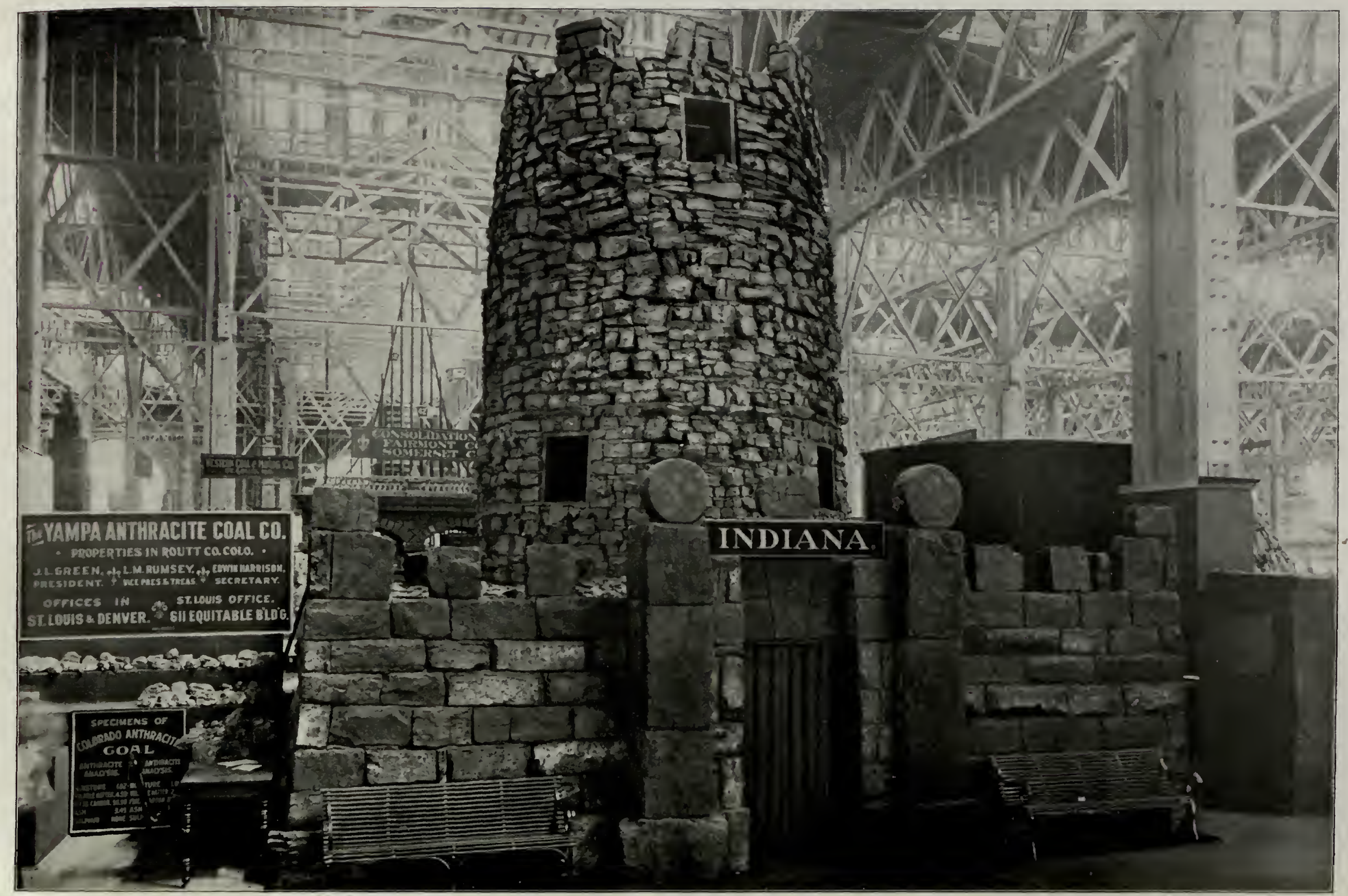




\section{Educational Exhibit}

As heretofore stated, the Committee on Education consisted of Fremont Goodwine, Chairman, C. C. Shi-ley, and D. W. Kinsey. This Committee asked for the endorsement and co-operation of the State Board of Education. This was promptly accorded and two meetings were held, at which general plans for the exhibit were discussed and circular letters issued to the school officials and teachers of the State urging them to take up the matter. The Committee made the State Superintendent of Public Instruction director of the Educational Exhibit. It was planned to have an exhibit from the State Library and the Public Library Commission as a part of the main educational exhibit, and also to have an exhibit in the department of Social Economy from the Board of State Charities, State Board of Health, the State Department of Inspection, the Marion County Juvenile Court and the School for Feeble Minded Youth at Fort Wayne, and very creditable exhibits were made by these departments.

The State Superintendent rendered valuable service in the preparation of the exhibit, and with his deputy, devoted much of the summer of 1903 to awakening interest in the matter in all parts of the state. It was determined to make an accurate showing of the status of school work in all grades and departments, and that the material must come from all the schools. As a result of the campaign eighty-two counties out of ninety-two, one hundred and twenty-seven towns and cities, and practically all the colleges and normal schools of the state made exhibits. This work was accomplished by the State Department of Education through county institutes, teachers' associations and other educational meetings, conferences with county superintendents, a convention of city superintendents, the issue of bulletins, and a vast deal of correspondence. The Commission acting on the recommendation of the Committee on Education and the State Superintendent of Public Instruction, appointed Superintendent W. A. Millis, of Crawfordsville, Superintendent of the department. Mr. Millis began the work at once, and performed the duties assigned to him with credit both to himself and to the state. With the aid of all these forces the State succeeded in bringing together the most general and faithful representation of all phases and conditions of educational effort in Indiana ever made.

\section{PREPARATION OF MATERIAL.}

The directions issued for the preparation of material for the exhibit are summarized in the following circulars:

CIRCULAR No 1.

Indianapolis, Indiana, October 5, 1903.

To the Teachers and School Offucials of Indiana:

"The International Exposition to be held in St. Louis in 1904 is designed to exemplify the highest achievements of man in letters, science, art and industry, together with a retrospective view of the historic developments of each of these great fields of sociology. It commemorates a great historic event, the purchase of the Louisiana territory and emphasizes the early international relation of our Government with foreign nations, particularly with France and Spain.

"The proclamation of President McKinley, issued August 20, 1901, invites all the nations of the world to participate in an international exhibition by sending such exhibits as will most fitly and fully illustrate their resources, their industries and their 
progress in civilization.

"The exposition will be opened May 1, 1904, and closed November 30 of the same year. It will be situated in Forest Park in the western suburbs of St. Louis and will occupy an area of about 1,000 acres.

"Education. - The great scale upon which the exposition is projected renders it possible for the first time in the history of "Expositions to provide a separate building for educational exhibits and to collect, under one roof, a comparative display of

The above from Circular No. 1, issued by Howard J. Rogers, Chief of the Department of Education, St. Louis Fair, is a fit The above from Circtlar No. 1, issued by How the ducational committee of the World's Fair Commission, the State Board fit introduction to what follows. It is the desir Public Instruction, that the Indiana exhibit shall not only be worthy of the great State but that it shall honestly represent the work of the pupils. An exhibit of pupils' work may be made to represent the work of the school with considerable clearness and fidelity, but in order to do this it must be honestly prepared and intelligently labeled. Very often written exhibits of pupils are almost worthless as a representation of methods used and results obtained because they show nothing of what has been done to aid the pupil to produce the work.

It is not intended in this circular to suggest all the things that schools may exhibit, nor in the directions following to limit the originality of individual exhibitors, but there are a few specific directions for preparing material that must be strictly adthe original appearance.

Exhibit Regulations.-Flat exhibits (charts, drawings, photographs. botanical specimens, kindergarten work, etc.) will be shown in stationary cabinets. The standard dimensions of all cards to be placed in these cabinets will be $22 \times 28$ inches, the latter dimension being vertical or up and down direction. It is recommended that all cardboard used for this purpose be of cloud gray color. Photographs for albums or wall cabinets should be either $8 \times 10$ inches or $11 \times 14$ inches.

Written Work.-1. Pupils' work should be written on paper 8 1-2 x 11 inches except in the subjects of drawing and botany. The paper used for the written work should be white superfine writing paper, twenty-four pounds to the ream. There should be a marginal line one and one-half inches from the left edge and one and three-fourths of an inch from the right edge. These two lines extend from the bottom of the page to points one and three-fourths inches from the top edge and a marginal line at the top connecting the above points, thus leaving a continuous margin one and one-half inches on the left, one and threefourths inches at the top and three-fourths inches on the right. The horizontal feint lines should extend only between the vertical lines. The spacing of the feint lines should be seven-sixteenths of an inch for the first five grades and six-sixteenths of tical lines. The spacing of the feint lines should be seven-sixteenths of an inch for the first five grades and six-sixteenths of
an inch for all grades above the fifth. All lines should be blue with the marginal one slightly heavier. Ruling should be on one side of the paper only and in no case should pupils write on both sides.

2. In drawing and mounting botanical specimens, the standard sizes of paper $(22 \times 28$ inches) should be used and the same margin should be left as noted above. Where drawings are not made upon the cardboard itself, they should be placed upon a good grade of drawing paper of suitable size for mounting on the standard cards, $22 \times 28$ inches, always remembering that the latter dimension is the vertical dimension.

The work of one grade in one subject should be arranged for binding separately. A photograph of the class as a frontispiece to each volume would greatly add to its interest.

piece to each volume would greatly add to its interest. Binding.--All binding for the exhibit will be done under the direction of the management of the exhibit and will be paid
for bv the State. No binding will be done before the work is sent to Indianapolis.

Photographs. - It is the desire of those in charge of the Indiana Exhibit that there shall be a large variety of photographs;
(n) that there shall be photographs of exteriors and interiors of rural, village and city schools, both public and parochial. Interior exercises. All these photographs should be either $8 \times 10$ or $11 \times 14$ inches and should culture, study or other legitimate school on cloud gray cardboard, size $22 \times 28$ inches.

Models for School Buildings and Grounds, including "Consolidated" Schools.-Indiana should be represented in this exhibit by a number of models in miniature of school houses and grounds, space being limited to twelve square feet. The models may be made of wood, clay or other suitable material,

Kindergarten.- Circulars relating to kindergarten work will be sent to the city superintendents later.

Laboratory Methods. - There is a large field for showing the laboratory method of work in the schools. There should be samples of work in physics, physiology, botany, zoology and chemistry. Zoological, botanical and physiological charts may be presented; also special drawings showing the work in physics and chemistry.

Manual Training.- Specimens of pupils' work in manual training, including sewing, wood work, cardboard work, weaving, knife work, etc., shoutld be sent in. If practicable, this work should be mounted as other kinds of work.

Mathematics. - Charts showing work in higher mathematics may be made. These should show original work in algebra, mathematics.

intendents should advertise for these - It will be of interest to exhibit the oldest text books to be found in the State. Super-

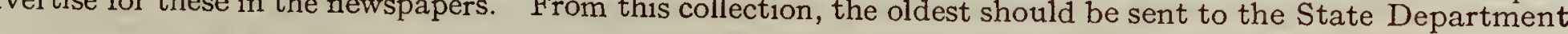

Miniature Models of the Oldest Desks and School Furniture to be found would add to the interest? of the exhibit. 


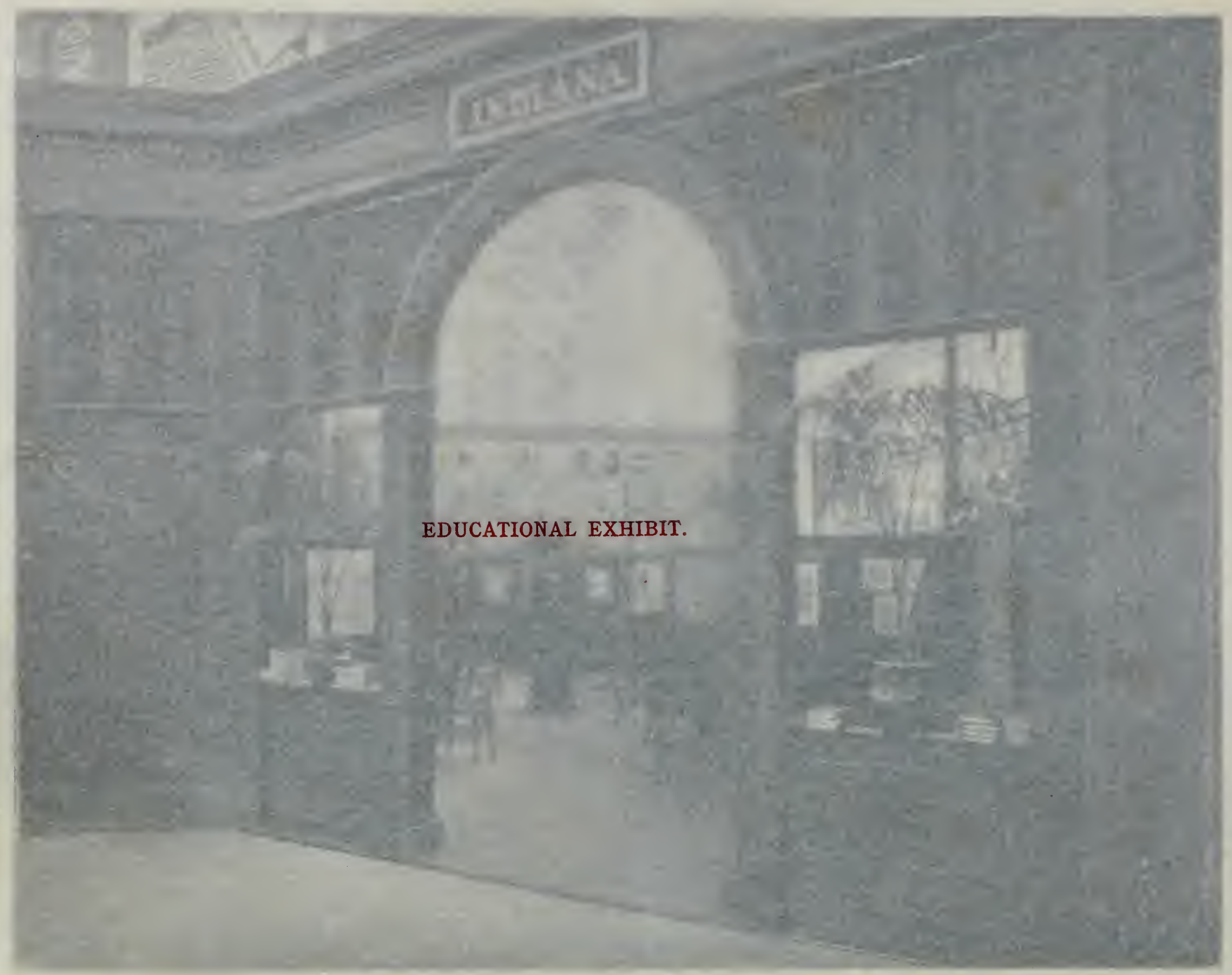




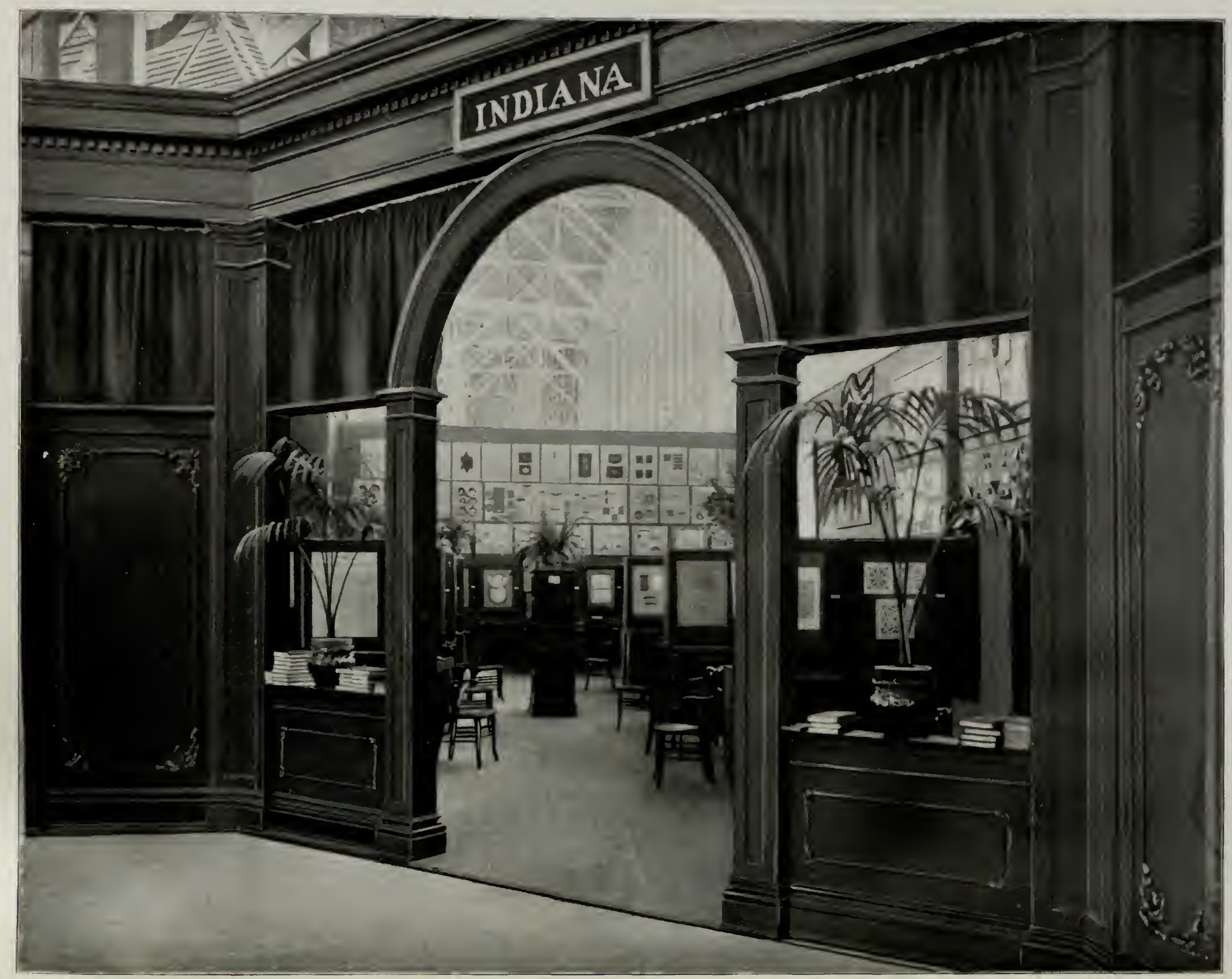


models should be made from the old furniture. If loaned, the old text books and models of furniture will be returned at the close of the exposition.

Suggestions for an Exhibit of Rural School Work.-In order to make the best possible showing of the rural school work, the following plan is suggested: Let the teacher of each district, village or town school prepare an educational exhibit at some time before December 20 . This local exhibit should be very carefully planned; patrons should not only be invited but urged to attend. They should know of it early in the term in order that their interest may grow along with that of the teacher and pupil. The best work from this exhibit should be sent to the county superintendent for a county exhibit to be held not later pupil. Thuary 15. Again, the patrons should be urged to be present. The best work will be selected from the county exhibit
than Janual and sent to the State department, from which a final selection will be made for the St. Louis Exposition.

In the work submitted for the exhibit should be found:

Written Work-

1. Collection of examination papers in spelling, United States history, physiology, geography, arithmetic, etc.

2. Collection of examination papers in any one branch.

3. Collection of letters or compositions from any one class.

4. Condensation of a fifty-word exercise into a telegram.

5. Township History.-All of the eighth grade pupils should be asked to write histories of their respective townships, the best in each township to be sent to the county and state exhibits. These histories should not exceed twenty pages of the regulation paper and should cover the following points:

(a) Time of organization.

(b) Early conditions of the township as to timber, roads, drainage, wild animals, Indians, etc.

(c) Early settlers-mention some prominent ones.

(d) Early schools, churches, towns, conveyances, farming implements, etc.

(e) Improvements in various phases of life.

(f) Occupations that the township resources encourage.

(g) Brief sketch of the leading enterprises in the township.

(h) Special attention paid to any men or women who have won special honor in the state.

(i) Description of any scene which has become well known for its beauty.

Drawing (Prang's Drawing Paper or its Equivalent).-

1. Set of illustrative drawings from any class in any branch not to exceed four by the same pupil.

2. Collection of free hand drawings not more than one by the same pupil.

3. Collection of original designs from any school, not to exceed one from the same pupil.

4. Collective exhibit in drawing from any school, not more than one drawing from the same pupil.

Apparatus-

1. Collection of illustrative apparatus made by the pupils of any school.

2. Chart or other graphic presentation of schemes or methods of work used by any teacher.

3. Graphic scheme of statistical information concerning any district or township.

Photography-

1. Collection of photographs of schools in working order.

2. Collection of photographs of school buildings and grounds.

3. Collection of photographs illustrating courses and methods.

4. Only good photographs will be accepted. The best photographers should do this work and even then the school officials. should oversee it to get the best results. Photographic displays will be a greater feature at this exposition than ever before and Indiana must be represented by first-class work.

5. To Show Actual Schoolroom Work.--Superintendents should select schools for special inspection. Have photographer take exterior and interior views of buildings. The interior should show the school, board work and decorations. A stenographer should be sent to the school to report the work including directions, questions and answers as given by teacher and pupils.

General Exhibits-

1. Display of the work of manual training schools.

2. Exhibit of school work of one pupil. This latter exhibit may also include any industrial work of the pupil done out of school.

All Children to be Represented --In order that all the children in the state may be represented in the exhibit, the following suggestion is offered: As soon as you receive regulation paper, have each pupil in school sign his name in the best hand possible; reserve a line under each signature for a later signature. On the day before sending papers to the county exhibit, have pupils sign again. This will insure each child representation in the exhibits and encourage good penmanship. 
County and State Exhibits. - Full suggestions will be given later with regard to the county exhibits. At the same time full directions will be given as to the manner of arranging for and shipping material to the state department.

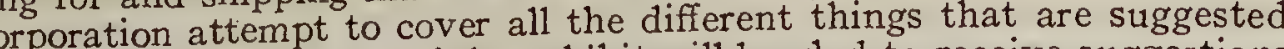
General. in this circular. Each school should do that wh be incorporated into circulars for the general public. It is earnestly hoped that from those interested which may or may not be incorporated into circulars for the may feel that he may do something to make every teacher in Indiana will become interested in the exhibit and that eve.

such a showing of the Indiana schools as the state has never had before.

All correspondence with regard to exhibit matter should A. COTTON, Director of Exhibit, Indianapolis, Indiana.

\section{CIRCULAR No. 2.}

Indianapolis, Indiana, January 5, 1904.

To the Teachers and School Officials of Indiana:

The educational exhibit of Indiana in the Louisiana Purchase Exposition to be held at St. Louis will be organized with the purpose in view of showing-

1. Indiana's solution of educational problems, as, school economy, organization, course of study, methods of instruction and training, supervision, co-ordination of school and community, etc.

2. The scope and organization of Indiana's educational effort, embracing all agencies having for their purpose the dissemination of knowledge and culture.

3. The status of school work throughout the state, under the varying conditions.

The emphasis will be placed on the first and second objects. For the most part the above will be exemplified by the exhibit of typical work of schools which have succeeded in accomplishing satisfactory results. Typical good work of schools of all

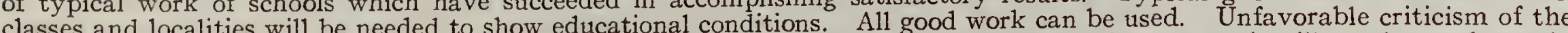
classes and localities will be needed to show educationaling selection of material. Unsatisfactory work will not be used merely state will be avoided so far as possible by a discriminating selection of material. Unsatisfactory work will not be used merely in order to give a corporation representation. The exhibit will be installed in such manner that the individuality of the corto the problem or phase of work exemplified. All work will be exhibited in swing frame cabinets.

Directions for Collecting and Shipping Exhibit Material.

1. Deliver in person or ship by express, prepaid, to F. A. Cotton, State Superintendent of Public Instruction, State House, Indianapolis, Indiana.

2. Send material by February 1.

3. The local school corporation must meet all expense of photographs, mounting, boards, stationery, and transportation to Indianapolis.

All binding will be done at the department of public instruction and paid for by the state. Corporations may have work returned by paying cost of shipping and reimbursing the state for the outlay for binding.

4. The cabinets will be filled by the director. All material submitted passes entirely into the control of the management.

5. Tying upand Packing Material. - (a) Written matter should be bunched by subjects or tied by grades, or with reference to both, in volumes from one inch to one and a half inches thick. 'These volumes should contain a title page as per diagrams furnished heretofore, and should be wrapped and tied separately. The name of the corporation and the nature of the contents should be placed on the outside of the wrapper. (b) The mounts of photographic and art work should be so packed as to prevent rubbing, or the crushing of the mounting boards. Every mounting board must have the name of the corporation printed at the top in the same style of type used in the diagram heretofore furnished you

6 . The cabinets are furnished by the state, but may be secured at the close of the exposition by reimbursing the state for the net cost. Applications for cabinets should be filed early.

Material.-You will materially facilitate the work of organization by preparing your exhibits so far as remains possible in accordance with the following suggestions:

1. There will be need of a great deal of written matter representing teaching units, exemplifying at the same time the organization of instruction, correlations, method and results. In geography the distribution of plant life is an example of the teaching unit. This topic requires several lessons for its presentation, and its treatment would be typical of geography teaching in the particular school. If each daily lesson on this topic is represented by two or three typical papers, maps or charts, the whole will form a small monograph on the subject and a good exposition of the teaching movement involved. An exhibit of the teaching of a literary selection, of a movement in history, of a typical plant or animal in nature study, will form desirable material. The unit of exhibit should be a "type study" or "lesson whole." Only a limited amount of miscellaneous, unconnected matter can be used.

Examination papers should be submitted exactly as they come from the pupil, transcribed to the regulation paper, without teacher's marks or corrections. In large county exhibits it is better to submit the best six to ten in each township. Each set of papers should be prefaced with a concise statement of the grade, the time allowed for the test, the number of weeks or months 
of study covered by the examination, whether the test was preceded by an oral review, and should be accompanied by a list of the questions used, properly numbered.

2. Laboratory note books, history books, etc., if approximately of the size of regulation paper, should not be transcribed, but submitted in their original form. The complete note book, just as it comes from the hand of the pupil, is preferred. All exhibits of laboratory methods must be prepared for binding. The space will not permit exhibit on mounting boards.

3. Maps and charts should be prepared for binding in with related written work, or arranged in portfolios. The former is preferred since it shows the place given to mapping and charting in the teaching process.

4. Photographs of pupils, laboratories, apparatus and working equipment should be inserted in the volumes of related written matter. The photograph, unmounted, may be attached to a sheet of the regulation paper by carefully pasting the upper edge only of the print.

5. Stenographic reports of recitations should not be submitted unless the work reprcsented is excellent. Reports of excellent work are very desirable. It is needless to say that the report should be faithful.

6. School made models should be exhibited by photograph unless otherwise specially requested.

7. Corporations should not attempt to exhibit manual training products unless they possess a fully organized course of training, well equipped and under expert direction. The fact of the introduction of manual training should be shown by graphics and photographs of pupils at work, and of the product. It is desired that all schools which have introduced manual training shall furnish such exhibit. The space allotted to manual training is so meager that only type pieces of work can be accepted. But the mass should be shown in photographs. The work accepted will be shown for the most part in cases.

8. Old text-books will be shown in cases, thus being protected from exposure and handling. Books actually used in the schools prior to 1860 are eligible.

9. Photographs of buildings and equipment should be arranged to show either excellence of attainment or the evolution of school architecture and furnishing. The exhibit should mean something. The photographs should be mounted directly upon the mounting board by the photographer. Only good photographs should be submitted.

10. The volume of art work offered by schools having complete courses of art instruction under expert direction is so great that only a fraction of it can be exhibited at one time in the wing frames. In order to give an equitable representation to all good systems of art work. supervisors should mount one set of cards (a minimum number) with types only. This set will show the scope and organization of instruction given together with the technical success. A sufficient number of duplicates of types mounted by grades to show that the types of the first set are typical of results in general should be submitted. These mounts of duplicates will be bound in portfolios at the department.

11. It is earnestly desired that township and city histories and the signatures of all school children shall be furnished as per request on pages three and four of circular No. 1.

All good work submitted will be used. An effort will be made to give the effort as a whole an organic unity. Your promptness in responding to the requests of the department is appreciated. We are sure that you will feel well repaid for the effort. We hope to have the benefit of any further suggestions for the better organization nf the exhibit.

Adjusting your exhibit to the foregoing as far as possible at this date, you will please send in all material offered in your formal report, except such items as may have been disposed of in personal correspondence.

\section{W. A. Mirector of Exhibit.}

\section{ORGANIZING PRINCIPLE}

The principle which guided in the selection and organization of material for the exhibit embraced three things:

1. The physical and personal equipment of the schools.

2. The scope and organization of instruction.

3. The standard of efficiency, or excellence, in schools of all kinds in all parts of the state, giving the objective of the conscious effort of teachers and officials.

The effort was to select material with reference to the evident standard of excellence in each school corporation-not with reference to the standards of any one corporation, nor to a state standard, nor with reference to the opinion of any judge or group of judges as to what constitutes good school work. It was the purpose to make the exhibit historically true-an exhibit of Indiana schools, not an exhibition by Indiana schools. Work was accepted not with reference to its inherent worth, but because it was adjudged to be representative of the best which the contributing schools could do, at least of what superintendents and teachers were satisfied to send out as representative work.

\section{TIME FOR PREPARATION}

Unfortunately, after instructions were issued for the preparation of exhibit materials, little more than three montlis remained in which the schools could prepare for the exhibit. However, it is probable that a more truly representative portrayal of actua school work was secured because the time was short. The material offered necessarily was a cross-section of actual daily work 
While the result could not be so attractive as an exposition feature, it certainly was more valuable for the student of educational conditions, and of more value to the exhibiting schools because it was a truer reflection of the actual situation.

\section{THE INSTALLATION}

Indiana was awarded a floor space of approximately seventeen hundred square feet at the southeast entrance in the Palace f Edrach of which was enclosed by of Education, one of the main exhibit palaces. This foor space was divided uniform volumes, half-leather, of about four $h\lrcorner n d r e d$ an attractive facade twelve feet high. The written matter was bound in uniform volumes, half-leather, of a exhibited in swingpages each. Photographic and art exhibits were mounted on boards, uniform in size, weight and color, and exhibited in swing-
leaf cabinets, thereby multiplying the exhibit space available thirty-three times. Exhibits of manual training were shown in wall frames and in glass cases with which most of the wing-frame cabinets were fitted. In all, one hundred and one wing-frame cabinets, a number of sectional book-cases, and a complement of library tables and chairs were used. The furnishings were in natural oak.

The material used, for the most part, was drawn from regular class exercises in which all pupils belonging to the class participated, and was selected as typical in form, method and contents of the regular instruction. The written work was done on uniform paper, from first draft work without correction, and arranged in volumes, first by subjects and then by $:-$ ra Jes. The uniform paper, from first draft work without correction, and arranged in volumes, fred thousand pages. The exhibit included written exercises filled some seven hundred volumes, aggregating about three hundred thousand pages. The exhibit included
also about twenty thousand photographs and pieces of art work, besides many hundreds of pieces of manual work. Wall charts exhibited the location and strength of reading circles, the location of schools and distribution of all the public school teachers in the state. The administrative system was shown by means of graphics and specimens of all forms, blanks, outlines, bulletins, courses of study, reports and other publications of the state department of public instruction, the whole filling three cabinets. A complete exhibit of text books used in the public schools at the present time was thrown into relief by a collection of the books used prior to 1860

The display of each corporation was shown as a unit. These units were so placed as to group the exhibits of higher and professional education in one part, the larger cities in another, the smaller cities in a third, the rural schools in a fourth, and the exhibits of the reading circles and of the administrative system in a fifth. It was thus easy for the visitor to go at once to the particular kind of work he wished to see. It also gave each kind of school the most favorable setting.

\section{LITERATURE}

A conspicuous feature of the exhibit was the quantity and character of the literature displayed and distributed. In addition to the full set of text books displayed, there was shown a complete set of books of both the teachers' and young people's reading circles. Besides the hundreds of copies of the school law, the state course of study, institute outlines, department bulletins, arbor day books, directories, and department reports which were distributed to students of education. The State University published a thousand copy edition of the university book in which the history of the university is reprinted, together with bibliography of the publications by faculty and alumni of the institution, and a very careful and unique study of the evolution a very care published a specially propared volume of over six hundred pafues exploiting respectively, in three divisons the administratio and status of elementary distributed. Two thousand five hundred copies of this volume were distributed. The State Librarian supplemented his large exhibit of the public library system of the state with a neat volume, specially prepared for the exposition, containing the history of every public and municipal library of the commonwealth. The reading circle board prepared and distributed several thousand copies of a neat little brochure containing the history of the reading circle movement in Indiana and a catalogue of all the books which have been used.

\section{CATALOGUE OF EXHIBITS}

The following catalogue of exhibits in the department of education shows not only the nature and extent of contributions accepted and the corporations represented, but also the official classification submitted to the juries on awards. A number of smaller towns organizing their exhibit in connection with their counties are not shown separately in the classification, but are grouped with their respective counties:

GROUP 1-CLASS 1-KINDERGARTENS

(1) Legislation-"School law of Indiana," page 133, section 130.

(2) General statement- "Education in Indiana," page 82.

(3) Indianapolis Normal Training School-Booth 2 , cabinet 9.

(b) Photographs of building, equipment, class rooms, classes in domestic science, etc.

of students.

(c) Photographs of model kindergartens. 
(d) Typical specimens of construction work-Glass case of cabinet 57 .

(4) Richmond-Cabinet 72: Photographs of classes and equipment, specimens of construction work.

(5) East Chicago-Cabinet 57: Photographs of classes and equipment.

(6) Hammond-Cabinet 51: Photographs of classes.

(7) South Bend-Cabinet 46: Photographs of classes and equipment, specimens of construction work.

(8) Covington-Cabinet 44: Specimens of construction and art work.

(9) Attica-Cabinet 40: Specimens of construction and art work.

(10) Laporte-Cabinet 39: Photographs of classes, two "work books," illustrating scope and organization of work.

(11) Terre Haute-Cabinet 22: Photographs of classes, kindergarten plans.

(12) Lake County-Cabinet 13: Photographs, specimens of construction work.

\section{CLASS 2-ELEMENTARY GRADES}

(1) The school system of Indiana-

(a) Outline, with specimens of forms, blanks, reports, bulletins, etc., and photographs, cabinets 1, 2, 3 .

(b) Monograph, "Education in Indiana, 1904, Cotton," division 1.

(c) "School Law of Indiana, 1904, Cotton."

(2) "Report of superintendent of public instruction, 1902, Jones."

(3) Supervision and management-

(a) Monograph-"Education in Indiana."

(b) School reports: 'Terre Haute, Shelbyville, Marion and Franklin.

(c) General statement: Indianapolis, cabinet 81.

(d) Forms and blanks: Crawfordsville, Terre Haute, department of public instruction.

(4) Distribution of schools: Wall map.

(5) Training of teachers-

(a) State normal school, cabinets 7 and 8, booth No. 2: Photographs of buildings, equipment and faculty; specimens of art work; bound volumes of specimen student papers.

(b) Valparaiso normal school-Cäbinet 10, booth 2: Photographs and specimens of art work; bound volumes of student papers; copies of books written by members of faculty.

(c) Danville normal school-Photographs.

(d) 'Teachers' reading circle-Set of books, monograph, and wall charts.

(e) Teachers' associations and institutes-"Education in Indiana."

(f) Examination and certification of teachers-"Education in Indiana."

(6) Methods of instruction-

(a) Bound volumes of pupils' papers.

(b) Mound volumes of pupils papers.

(b) Monograph of city of Manion. ${ }^{\circ}$ Indianapolis.

(c) Stenographic reports of recitations, 'Indianapolis.

(d) Stenographic reports of recitations, Greenfield.

(f) Bound volume of teachers' plans, Crawfordsville.

g) Monographs on primary methods in bound volume of "Primary instruction," Crawfordsville.

(h) Teachers' plans and stenographic lesson reports, Terre Haute.

(i) Stenographic lesson reports, Bloomington.

(i) Stenographic lesson reports, Monroe county.

(k) Stenographic lesson reports, Randolph county.

(1) Stenographic lesson reports, Brown county.

(7) Rural schools-

1. Delaware county-Cabinet 4: Photographs showing buildings, centralization, and transportation of pupils; specimens of industrial work; three volumes of specimen pupils' papers.

2. Howard county-Cabinet 4: School architecture, transportation of pupils, and volume of specimen papers.

2. Forses

4. Parke county-Photographs of teachers and typical schools; four bound volumes of pupils' work.

4. Parke county-Photographs of teachers and typical schools, four bound drawings; five volumes of pupils' papers.

6. Jay county-Cabinet 5: Photographs and specimens of drawings; four volumes of specimen papers. 
7. Allen ofs, specimens of map making, and volumes of pupils' papers.

列

9. Union county-Cabinet 7: Photographs of teachers and buildings; specimens of m

papers.
10. Gibson county-Cabinet 7: Photographs of schools; volume of pupils' papers.

11. Rush county-Cabinet 7: Photographs, specimens of construction work; two volumes of pupils papers.

12. Lagrange county-Cabinet 8: Photogra and volume of specimen papers.

13. Fayette county-Cabinet 8: Specimens of drawings.

14. Crawford county-Cabinet 8 : Specimen draws

15. Huntington county-Cabinet 9: Photographs, specimens

16. Knox county-Cabinet 10: Volume of specimen papers.

17. Orange county-Cabinet 10: Volume of specimen papers.

18. Brown county- Cabinet 10. Volume of specimen papers.

19. Owen county- Two volumes of specimen papers.

20. Jasper county-Cabinet 10. Volume of specimen papers.

21. Steuben county-Cabinet 10: Volume of specimen paperimen papers.

22. Ripley county-Cabinet 10: Two volumes of specimen pap

23. Noble county-Cabinet 10: Volume of specimen papers.

24. Dubois county-Cabinet 10: Volume of specimen papers.

25. Hendricks county-Cabinet 11: Three volumes of specim

26. Ohio county-Cabinet 10: Volume of specimen papers.

27. Sullivan county-Cabinet 12: Five volumes of specimen papers.

28. Benton county-Cabinets 11 and 12: Photographs of recitation or building of each school

29. Grant county-Cabinet 13: Specimens of drawings and three volumes of pupils papers industrial work, centraliza-

30. Lake county-Cabinet 13: Photog

tion, specimens of drawings.

31. Clay county-Cabinet 13: Two volumes of pupils' work.

32. Wabash county-Cabinet 14: Specimen maps and drawings,

34. Pulaski county-Cabinet 15: Specimen drawings, three volumes.

35. Newton county-Cabinet 15: Volume of specimen papers.

36. Switzerland county-Cabinet 15: Volume of specimen papers.

37.

38. Johnson county-Cabinet 16: Photographs of schools.

39. Jackson county-Cabinet 16: Photographs of schools, volume of papers.

40. Hancock county-Cabinet 16: Photographs of schools, two volumes of papers.

41. Tippecanoe county-Cabinet 17: Photographs of schools, fourteen volumes of papers. construction work; three volumes of papers.

43. Spencer county-Cabinet 17: Photographs of schools.

44. Wayne county-Cabinet 18: Photographs showing improvement of school buildings; specimen drawings; four volumes of papers.

45. Vigo county-Cabinet 19: Photographs; volume of pupils' papers.

46. Shelby county-Cabinet 19: Photographs; two volumes of papers.

46. Madison county-Cabinet 19: Photographs; maps; four volumes of papers.

47. Madison county-Cabinet 19: Photographs; maps; four volumes of papers.

48. Monroe county-Cabinet 21: Photographs; maps; two volumes of papers. Marion county
papers.

50. Henry county-Cabinet 21: Photographs; seven volumes of papers.

51. Warren county-Cabinet 22: Photographs; seven volumes of papers.

52. Porter county-Cabinet 23: Photographs; two volumes of papers.

53. Laporte county-Cabinet 24: Photographs; specimen drawings; seven volumes of specimen papers.

54. Jefferson county-Cabinet 27: Volume of specimen papers.

55. Hamilton county-Cabinet 29: Two volumes of specimen papers.

56. Franklin county-Cabinet 30: Sewing; drawing; twenty-one volumes of specimen papers 
57. Fulton county-Photographs of schools, on walls.

58. Wells county-Cabinet 29: Photographs; two volumes.

59. Vermillion county-Cabinet 35: Volume of specimen papers.

60. Marshall county-Cabinet 36: Volume of specimen papers.

61. Bartholomew county-Cabinet 44: Six volumes of specimen papers.

62. Jennings county-Cabinet 45: Two volumes of specimen papers.

63. Dearborn county-Cabinet 45: Two volumes of specimen papers.

65. St. Joseph county-Cabinet 46: Volume of specimen papers.

65. Putnam county-Cabinet 49: Volume of specimen papers.

66. Decatur county-Cabinet 52: Eleven volumes of specimen papers.

67. Daviess county-Cabinet 54: Photographs; thirteen volumes of specimen papers.

68. DeKalb county-Cabinet 15: Volume of specimen papers.

70. Scott county-Cabinet 10. Volume of specimen papers

71. Greene county-Cabinet 10. Volume of specimen papers.

72. Warrick county-Cabinet 1: Photographs.

(8) Village, town and city schools-

1. Michigan City-Cabinets 77, 78, 79: Photographs of equipment; specimens of art work; four volumes of specimen papers illustrating all subjects.

2. Greencastle-Cabinet 76: Photographs of equipment; specimens of art work; three volumes of specimen papers.

3. Fort Wayne-Cabinets 67, 68, 69 and 70: Photographs of buildings, equipment, physical culture specimens of art work illustrating scope and character of instruction; fifteen volumes of written work illustrating all subjects in course of study.

4. Richmond-Cabinets 70,71,72: Photographs of schools and equipment of exhibits of industrial work, arts and crafts, school excursions; specimens of art work by grades; types of industrial work; nineteen volumes of pupils' written work in all subjects.

5. Marion-Cabinets 72, 73, 74: Specimens of art work for all grades; types of industrial work; seventeen volumes of pupils' written work in all subjects.

6. Indianapolis--Seven cabinets, section 8: Portrayal of course of study by means of outlines and specimen papers in wing frames; fifty-four volumes of class exercises in all subjects; photographs of typical buildings and interiors, of classes in domestic science, of field studies; set of models in sewing and sloyd.

7. East Chicago-Cabinets 56 and 57: Photographs of manual training exhibits, typical classes and schools; specimens of art work; four volumes of written class work.

8. Greenfield-Cabinet 56: Nine volumes of pupils' written work in all subjects.

9. Cambridge City-Cabinet 55: Specimens of art work, volume of pupils' written work.

10. Winchester-Cabinet 55: Photographs; volume of written work

11. Washington-Cabinet 54: Photographs of schools; two volumes of pupils' written work

11. Washington-Cabinet 54: Photographs of schools

13. Lebanon-Cabinet 55: Photographs and specimen drawings; three volumes of written work.

14. Huntington-Cabinets 48 and 54: Photographs of schools, types of manual training, specimens of pupils' art work books.

15. Wabash-Cabinet 53: Photographs and specimens of pupils' art; four volumes of written work.

16. North Manchester-Cabinet 52; Photographs and specimens of pupils' art.

17. Greensburg-Cabinet 52: Five volumes of written work in all subjects.

18. Portland-Cabinet 52: Photographs and specimens of art work; volume of specimen papers.

19. Hammond-Cabinet 51: Photographs of typical schools, class work, and types of art and industrial work; two volumes of pupils' papers.

20. New Albany-Cabinets 49,50 and 51: Photographs of schools and classes in physical culture; specimens of art work and map making; five volumes of specimen papers.

21. Roachdale-Cabinet 49: Specimens of drawing; volume of pupils' papers.

22. Shelbyville-Cabinet 47: Photographs of buildings and schools; specimens of pupils' art; three volumes of pupils'

papers.

23. South Bend-Cabinet 46: Photographs of schools; specimens of pupils' art; nine volumes of pupils' papcrs illustrating all subjects.

24. Lawrenceburg-Cabinet 45: Photographs and two volumes.

25. Aurora-Cabinet 46: Specimens of art; two volumes.

26. Columbus-Cabinet 45 : Specimens of maps; eleven volumes of pupils' written work. 
27. Vernon-Cabinet 45: Photographs.

28. Covington-Cabinet 44: Photographs of sehools and art exhibit; volumes of speeimen papers.

29. Covint

30. New Castle-Cabinet 43: Photographs and speeimens of pupils' art; two volumes of written work.

31. Middletow

31. Middletown-Cabinet 43: Five volumes of pupils wimens

32. Kokomo-Cabinet 42: 'Sotoimens of pupils' art; two volumes of speeimen exereises; work books.

33. Anderson-Cabinet 41: Speeimens of pulum of pupils' papers.

35. Summitville-Cabinet 41. Two volumes of elass exes in all subjeets

35. Crawfordsville-Cabinet 40: Photographs of sehools and buildings, ten volu specimen exercises.

36. Attiea-Cabinet 40: Speeimens of pupils' art and manual work; volume of specinen exereises.

37. Darlington-Cabinet 40: Volume of specimen papers.

38. Whiting-Cabinet 39: Photographs of schools; two volumes of pupils' written work.

39 Laporte-Cabinet 39: Photographs of sehools and equipment, specimen maps, and thirty-two work books containing typical work of all pupils in all grades.

40. Alexandria-Cabinet 38: Specimens of pupils' art; four volumes of elass work.

41. Columbia City-Cabinet 37 : Five volumes of speeimen exereises.

42. Goshen-Cabinet 37: Photographs; specimens of pupils'art.

43. Crown Point-Cabinet 36: Photographs; specimens of art; volume of speeimen papers.

44. Valparaiso-Cabinet 36: Exhibit of pupils' art.

45. Bremen-Cabinet 36: Exhibit of pupils' art; volume of pupils' papers.

46. Plymouth-Cabinet 36: Volume of speeimen papers.

47. Cayuga-Cabinet 35: Photographs and specimens of art; two volumes of specimen papers.

48. Rushville-Cabinet 35: Speeimens of art work; volume of specimen papers.

49. Carthage-Cabinet 35: Volume of written work.

50. Elkhart-Cabinet 34: Specimens of art work; two volumes of English eomposition.

51. Liberty-Cabinet 34: Art exercises; volume of written work.

52. Montezuma-Cabinet 34 . Art exercises, volume of writtcn work.

53. Coilege Corner-Cabinet 34: Four volumes of written work.

54. Connersville-Cabinet 33: Speeimens of art work; seven volumes of typieal pupils' papers.

55. Monticello-Cabinet 32: Photographs; volume of specimen exerciscs.

56. Woleott-Cabinet 32: Photographs.

57. Reynolds-Cabinet 32: Photographs.

58. Monon-Cabinet 32: Photographs; volume of speeimen papers.

59. Brookston-Cabinet 32: Photographs.

60. Williamsport-Cabinet 32: Speeimen drawings; two volumes of written cxereises.

61. Salem-Cabinet 32: Three volumes of written work.

62. Tell City-Cabinet 32: Seven volumes of written work.

63. Franklin-Cabinet 31: Photographs; specimens of pupils' art; note books; four volumes of pupils' exercises.

63. Franklin-Cabinet 31: Photographs; specimens of pup

64. Brookville-Cabinet 30: Two volumes of written work

65. Oldenburg-Cabinet 30: Speeimens of needlework and drawing; three volumes of written work.

66. Bluffton-Cabinet 29: Photographs of schools, shops, elasses in manual training, field and laboratory work speeimens of art and manual training; four volumes of pupils' exereises.

67. Noblesville-Cabinet 29: Three volumes of written work.

68. Parker City-Cabinet 29: Volume of English papers.

69. Sheridan-Cabinet 28: Photographs; ten volumes of class exercises.

70. Lafayette-Cabinet 28: Photographs; seven volumes of class exereises in penmanship.

71. Muncie-Cabinet 28: Photographs of sehools; four volumes of speeimen exereises.

72. Corydon-Cabinet 27: Photographs; sewing; drawing; two volumes of specimen papers.

73. Union City-Cabinet 27: Photographs; art work; volume of English and arithmetie papers.

74. Delphi-Cabinet 26: Speeimens of art work; volume of speeimen papers.

75. Terre Haute-Cabinets 25 and 26: Photographs showing improvement in buildings and equipment; photographs of pupils; of elasses in physical culture; typical manual work; fourteen volumes of examina ion papers and class exereises.

76. Bloomington-Cabinet 21 and walls: Typical sewing and sloyd work; photographs of schools; photographs of

77. Tonesboro-Cabinet 19: Volumes of elass exercises.

78. Seymour-Cabinet 16: Volume of specimen papers. 
79. Star City-Cabinet 15: Volume of specimen papers.

80. Winamac-Cabinct 15: Volume of specimen papers.

81. Kentland-Cabinet 15: Volume of specimen papers.

82. Butler-Cabinet 15: Volume of specimen papers.

83. Gas City-Cabinet 13: Two volumes of specimen papers.

84. Sullivan-Cabinet 12: Two volumes of specimen papers.

85. Danville-Cabinet 11: Two volumes of specimen papers.

86. Vincennes-Cabinet 10: Photographs and specimen drawings.

87. Scottsburg-Cabinet 10: Three volumes of written work.

88. Rising Sun-Cabinet 10: Volume of written work.

89. Knox-Cabinet 6: Two volumes of written work

90. Rockville-Cabinet 5: Volume of written work.

91. Red Key-Cabinet 5: Volume of written work.

92. Albany-Cabinet 4: Two volumes of written work.

93. Vevay-Cabinet 15: Volume of pupils' exercises.

94. Lapel-Cabinet 19: Volume of pupils' exercises.

95. Frankton-Cabinet 19: Volume of pupils' exercises.

96. Kennard-Cabinet 21: Volume of pupils' exercises.

97. Knightstown-Cabinet 21: Volume of pupils' exercises.

98. Bloomfield-Cabinet 15: Volume of pupils' exercises.

99. Seymour-Cabinet 16: Volume of pupils' exercises.

100. Dublin-Cabinet 18: Volume of pupils' exercises.

101. Galveston-Cabinet 41: Volume of pupils' exercises.

(9) The Young People's Reading Circle-

(a) Complete set of books used since 1884

(b) Monograph.

(c) Wall map.

\section{GROUP 2-SECONDARY EDUCATION.}

1. Howe military school, Lima-Two portfolios of photographs.

2. St. Mary's academy, Notre Dame-Photographs of buildings and grounds.

3. St. Joseph's college, Rensselaer-Photographs.

4. St. Augustine's academy-Photographs.

5. Institute of the immaculate conception, Oldenburg-Photographs.

6. Culvèr military institute, Culver-Equestrian statue, aisle 1.

7. Michigan City high school-Cabinet 78: Volumc of Latin, German and history papers; volume of English papers; volume of mathematics and science papers; specinens of art work-cabinet 79

8. Greencastle high school-Cabinet 76: Volume of German and Latin papers; volume of science and inathematics

papers; volume of English and history papers.
9. Marion high school-Cabinets 72 and 73: Volume of English, language and history; volume of mathematics and science; volume of Latin and history.

10. Richmond high school-Cabinets 70,71 and 72: Volume of students' papers in mathematics; volume of students' papers in physics and chemistry; two volumes of students' papers in English; volume of students' papers in botany; volume of students' papers in German; volume of students' papers in music.

11. Fort Wayne high school-Cabinets 67, 68,69 and 70: Photographs of buildings and cquipment; volume of English and history papers; volume of English papers; volume of history papers; twenty scicnce note books.

12. Shortridge high school of Indianapolis-Cabinet 8.5: Outline of courses of study; specimen sheets of daily paper specimens of students' art work; photograph of equipment; two volumes of history and civics papers; lour volumes of student publications; two volumes of science papers and notes; volume of mathematics; two volumes of foreign language papers; two volumes of English papers.

13. Manual Training high school of Indianapolis-Cabinet 8.6: Courses of study; photographs of equipment; photographs of laboratories; photographs of shops, models and finished articles; specimens of art work of students; graphs of laboratories; photographs of shops, models and finished articles; specimens of art work of students, volume of German, history a

matics and language papers.
14. East Chicago high school-Cabinct 57: Volume of students' papers

15. Greenfield high school-Cabinet 56: Volume of history papers; volume of papers in mathcmatics and science; 
photographs and specimens of science notes.

Cots papers.

17. Odon high school-Cabinet 55: Part volume of students' papers.

18. Winchester high school-Cabinet 55: Volume of science note books

19. Washinton high school-Cabinet 54: Volume of students' papers.

20. Waviess county township high schools-Cabinet 54 : Volume of students' papers.

20. Daviess county township high schools-

21. Wabash high school-Cabinct 53: Parts of four vimens of art work of students; photographs.

22. North Manchester high school- Cabinet 52: Specip equipment; part volume of papers.

23. Portland high school-Cabinet 52 : Photographs of equipment,

24. Greensburg high school-Cabinet 52: Volume of student papers.

25. Hammond high school-Cabinet 51: Photographs of athletic organizations, of student papers; specimen plant mounts-cabinet 50

27. Lebanon high school-Cabinet 50: Volume of student papers in English; volume of papers in English and history.

28. Roachdalc high school-Cabinet 49: Volume of English papers; volume of student papers.

29. Huntington hioh school-Cabinet 54: Photographs of building; specimens of art work.

30. Shelbyville high

31. South Bend high school-Cabinet 46: Volume of mathematics and science papers; volume of English, language and history papers; photographs of athletic teams.

32. Columbus high school-Cabinet 45: Volume of student papers in commercial geography; volume of papers in history; spccimens of historical mapping.

33. Lawrenceburg high school-Cabinet 45 : Volume of student papers.

34. Jennings county high schools-Cabinet 45 : Volume of student papers.

35. Covington high school-Cabinet 44: Volume of student papers; photographs.

36. Bartholomew county high schools-Cabinet 44: Volume of student papers.

37. New Castle high school-Cabinet 43: Photographs of building, equipment and pupils; specimens of art work; volume of specimen papers.

38. Middletown high school-Cabinet 43: Volume of specimen papers in English; volume specimen papers in history; volume

39. Galveston high school - Cabinet 42: Part volume of specimen papers.

39. Galveston high school-Cabinet 42: Part volume of specimen papers.

40. Kokomo high school-Cabinet 42: Volume specimen papers history and science.

42. Anderson high school-Cabinet 41: Specimens of mechanical draw

43. Attica high school-Cabinet 41: 'Volume of student papers.

44. Crawfordsville high school-Cabinet 40: Courses of study; class annual; athletics; photograph of building; volume of papers of entire class covering a wcek's work in algebra and geometry notes; bound volumes of typical history note books; bound volumes of English note books and papers; volume of typical Latin papers; volume of typical German papers, and specimen research papers in botany; bound volume of science note books.

45. Laporte high school-Five portfolios of specimens of art work, illustrating the course of instruction; three"work books" containing specimen papers illustrating courses of study.

46. Whiting high school-Cabinet 39: Volume of student papers.

47. Alexandria high school-Cabinet 38: Parts of three volumes of specimen papers

48. Laporte county township high schools-Cabinet 38: Volume of specimen student papers.

49. Columbia City high school-Cabinet 37: Volume of specimen papers.

50. Goshen high school-Cabinet 37: Photographs of school.

51. Valparaiso high school-Cabinet 36: Volume of student papers.

52. Crown Point high school-Cabinet 36: Volume of specimen papers.

53. Bremen high school-Cabinet 36: Part of volume of specimen papers.

54. Plymouth high school-Cabinet 36 : Volume of specimen papers.

55. Carthage high school-Cabinet 35: Part volume of specimen papers.

56. Cayuga high school-Cabinet 35: Part volume of specimen papers.

57. College Corner high school-Cabinet 34: Two volumes of specimen papers

58. Liberty high school-Cabinet 34: Part of volume of specimen papers.

59. Elkhart high school-Cabinet 34: Specimens of art work.

60. Bluffton high school-Cabinet 35: Specimens of art work; photographs of manual training and equipment cabinet 29; sewing, case of cabinet 29; models, wall over cabinet 29; volume of student papers in mathematics 
and history; volume of student papers in physics and chemistry; volume of student papers in botany and zoology; volume of student papers in English and foreign language.

61. Connersville high school-Cabinet 33: Volume of language and mathematics papers; volume of English papers: volume of history papers.

62. Salem high school-Cabinet 32: Volume of history; volume of mathematics and science.

63. Monticello high school-Cabinet 32: Part of volume of specimen papers.

64. Monon high school-Cabinet 32: Part of volume of specimen papers.

65. Williamsport high school-Cabinet 32: Specimens of science drawings; part of volume of student papers

66. Franklin high school-Cabinet 31: Photographs of buildings, teachers and pupils; volume of botany and zoology papers; volume of history and English papers.

67. Brookville high school-Cabinet 30: Volume of English and Latin papers.

68. Laurel township high school, Franklin county-Cabinet 30: Volume of specimen papers.

69. Wells county high schools-Cabinet 29: Volume of specimen papers.

70. Sheridan high school-Cabinet 28: Volume of science papers; volume of Latin and mathematics; two volumes of history.

71. Muncie high school-Cabinet 28: Volume of spccimen papers

72. Corydon high school-Cabinet 27: Volume of English papers; volume of specimen papers in history, mathcmatics and science.

73. Terre Haute high school-Cabinets 25, 26: Volume of student papers in history; volume of student papers in science and Latin; volume of student papers in German; volume of student papcrs in mathematics.

74. Warren county high school-Cabinet 22: Volume of specimen paper

75. Kennard high school-Cabinet 21: Part volume of student papers.

76. Spiceland academy-Cabinet 21: Volume of specimen papers.

77. Bloomington high school-Cabinet 21: Photographs of school (on west wall); parts of three volumes of papers.

78. Lapel high school-Cabinet 19: Part of volume of specimen papers.

79. Frankton high school-Cabinet 19: Part volume of specimen papers.

80. Wayne county high schools-Cabinet 18: Volume of specimen papers.

81. Dublin high school-Cabinet 18: Part of volume of specimen papers.

82. Tippecanoe county high schools-Cabinet 17: Volume of English and history papers; volume of mathematics and science.

83. Hancock county high schools-Cabinet 17: Volume of student papers.

84. Bloomfield high school-Cabinet 15: Part volume of English.

85. Vevay high school-Cabinet 15: Part volume of English papers.

86. Butler high school-Cabinet 15: Volume of specimen papers.

87. Kentland high school-Cabinet 15: Part volume of specimen papers.

88. Star City high school-Cabinet 15: Part volume of English papers.

89. Winamac high school-Cabinet 15: Part of volume of specimen papers.

90. Wabash county high schools-Cabinet 14: Photographs of buildings; volume of student papers.

91. Tipton county high schools-Cabinet 14: Volume of specimen papers in Latin and English; volume of specimen Tipton county high schools- Cabinet $14:$

92. Lowell high school-Cabinet 14: Part of volume of specimen papers.

93. Tonesboro high school-Cabinet 14: Part of volume of specimen papers.

94. Lake county high schools-Cabinet 13: Photographs of buildings, equipment and class work; volume of specimen papers.

95. Clay county high schools-Cabinet 13: Part volume of specimen papers.

96. Gas City high school-Cabinet 13: Part of volume of specimen history papers.

97. Danville high school-Cabinet 11: Volume of specimen papers.

98. Benton county high schools-Cabinet 11: Specimen science drawings and notes.

99. Hendricks county high school-Cabinet 11: Volume of specimen papers.

100. Clarksburg high school-Cabinet 10: Volume of specimen papers.

101. Scottsburg high school-Cabinet 10: Volume of specimen papers.

102. Huntington county high schools-Cabinet 9: Photographs of buildings; specimens science drawings.

103. Lagrange county high schools-Cabinet 8: Photographs of buildings; part of volume of specimen papers.

104. Penville high school-Cabinet 6: Volume of specimen papers.

105. Knox high school-Cabinet 7: Part volume of papers.

106. Jay county high schools-Cabinet 6: Volume of specimen papers.

107. Rockville high school-Cabinet 6: Part of volume of specimen papers. 
108. Albany high school-Cabinet 5: Volume of specimen papers.

109. Delaware county high schools-Cabinet 5 .

110. Fountain county high schools-Cabinet 5.

111. Fint volume of student papers

111. Rising Sun high school-Cabinet 10: Part volume of the state, "School Law of Indiana, Cotton, 1904," page 121, 112. Provision of high

114. Course of

115. High of study for commissioned high schools," "Eage 194.

116. Distribution of high schools through state, wall map.

high schools, showing supervision, teaching facilities, professional training of tcachers in each school, salaries, attendance, etc., "Education of Indiana," pages 232 to 470

118. Township high schools, "Education in Indiana," page 471 .

\section{GROUP 3.-HIGHER EDUCATION. BOOTH 2.}

1. Wabash college, Crawfordsville-Cabinet 1: Photographs of faculty, student body, buildings and equipment; statements of administration and history.

2. Earlham College, Richmond-Cabinet $2-$ -

(a) Photographs of faculty, stion and history.

(c) Album of photographs.

(d) Album of photographic prints.

3. DePauw university, Greencastle-Cabinet 3-

(a) Photographs of buildings and equipment.

(b) Statistical tables.

(c) Album of photographs.

4. Butler university, Indianapolis-Cabinet 4-

(a) Photographs of equipment.

(b) Statements of administration.

5. Purdue University, Lafayette-Cabinet 5-

(a) Photographs of campus, buildings and interiors.

(b) Special exhibit, aisle 2, block 7 .

(c) Special exhibit with agricultural colleges and experiment stations, block 8 .

(d) Special exhibit of chemistry in Electricity Building.

6. Franklin college, Franklin-Cabinet 6-

(a) Photographs of faculty and equipment.

(b) Statements of growth and administration.

7. Union Christian college, Merom-Cabinet 4: Photographs of campus and buildings.

8. Indiana university, Bloomington-Cabinet $9-$

(b) The University Book, tracing the development of the curriculum from 1828 to 1904.

9. Hanover college, Hanovcr-Photographs of buildings.

10. Rose Polytechnic, Terre Haute-Photographs of buildings.

11. Univcrsity of Notre Dame, Notre Dame-Wall frame containing views.

11. Univcrsity of Notre Dame, Notre Dame-Wall frame containing views.

13. Legislation relating to state universities in "School Law of Indiana, 1904, Cotton," chapter 24, pages 339 to 370 , and chapter 25 , pages 371 to 381

14. The municipal and institutional libraries of Indiana, cabinets 11,12 and 13.

(a) Photographs of buildings and interiors of all public and institutional libraries.

(b) Charts showing location of libraries, number of volumes, circulation.

(c) Monograph giving the history of each library in the state.

15. The state library commission-Cabinet 14 -

(a) Exposition of history, scope and methods of work, and of results obtained.

16. Indiana federation of women's clubs, and Indiana union of literary clubs. 


\section{GROUP 7.}

Exhibit of the Indiana school for feeble-minded youth, Fort Wayne; with the collective exhibit of "American institutions for the care of the feeble-minded."

The exhibit was open to visitors from 9 to 6 o'clock every day except Sundays from the first of May until the first of December. It is gratifying to report that the Indiana exhibit proved one of the most popular displays in the Education building. The visitors numbered scores of thousands. The director and two trained assistants were kept busy constantly explaining exhibits to parents.

\section{STATE CHARITIES EXHIBIT}

In the exhibit of the Board of State Charities was shown in condensed form, the history, development, scope and operations of Indiana's charities. Under the term "charities" are classified both the charitable and correctional institutions, including public and private organizations and their supervision by state authorities .

There were about seventy-five cards in the exhibit. On one of these was given an outline showing the development of the state's charities from the earliest territorial days.

This outline also showed the development of the penal and correctional system of the state, from the territorial days of stocks and pillories to the present time, when each county is provided with a jail, and the state has a prison for men, a reformatory for young men, a school for boys, a prison for women, an industrial school for girls, the juvenile court for the trial of delinquent children, and the probation system for such of these as are found needing oversight. For the supervision of the entire system of charities and correction, the Board of County Charities for each county in the state was authorized in 1899.

Another card contained an outline map of the State of Indiana, showing in different colors the charitable and correctional institutions in the state, both public and private.

Several cards were devoted exclusively to the work of the Board of State Charities, stating briefly its purpose and duty, the conditions existing in the state before its organization, some of the reforms it has brought about, laws which have been passed on its recommendation by the General Assembly, and the work it is doing for dependent children. There were samples of the blanks and cards used in the collection and preservation of sociological data, and copies of the annual report, the quarterly bulletin, and the "Prison Sunday" pamphlet published by the Board. By the use of shaded maps, a striking exhibit was made of the reduction brought about in recent years in the amount of aid given the poor by township trustees.

Four cards were entitled "Prisons and Prisoners." These showed the population of the state, county and town correctional institutions, the population of the state's penal institutions by decades since 1830, the provisions for contract labor in the State Prison and Reformatory, and the operations of the indeterminate sentence and parole law.

A valuable part of the exhibit was that portion devoted to statistics showing the inheritance of feeble-mindedness. One card contained a study of all defective families in which, including those related by marriage, there are 1,924 
persons, 70 per cent. of whom are defective. Another was a study of 241 defective families, including only direct descendants, 970 in number. Eighty per cent. of these are defective and 75 per cent. of the direct descendants are feeble-minded.

The remainder of the cards contained photographic views of state institutions, county poor asylums, jails, hospitals and orphans' homes.

\section{EXHIBIT OF THE INDIANA SCHOOL FOR FEEBLE-MINDED YOUTH}

The school department of the Indiana School for Feeble-Minded Youth was represented at the St. Louis Exposition by the exhibits from six divisions, viz: The kindergarten grade, lace making and bead work, fancy work, art and pyrography. The quality of the work compared favorably with that of the public schools of the outside world, with but two qualifications: First, the pupils enrolled in these grades of work would average from five to ten years more in age than the normal child; and second, three or four years are generally spent in one grade.

The kindergarten pupils displayed studies in water colors, shaping for example, tulips, wild roses, American flags, etc., and coloring the same. Charts were to be seen containing samples of busy work, weaving, folding, drawing, sewing, perforation and parquetry mounting. In this department of the school display originality was lacking, but neatness was manifest and the deftness with which it was performed would surpass the child favored with normal mind.

The grade work covered the first five years of common school work and consisted of number work, geography, map drawing and illustrated work in history, physiology and nature study. The illustrated work was exceptional and would do credit to a public city school. The early settlements of Jamestown and Plymouth were sketched and the implements used in leveling the forces of nature and stocking the common store houses for the winter's supply were as vividly traced on the papers as were the same illustrations of the text implanted on the mind of the child, mentally deficient though it was.

The drawings in physiology, including the heart, lungs, skull, structure of bones, etc, were. as clear in detail as similar cuts in their books. In nature work, animal and plant life were depicted in appropriate colors.

The class in pyrography offered several pieces of wood and leather which required delicacy of touch and artistic sense to retain values and character. They were especially creditable. The work was principally by one pupil with three years' work of one-half hour daily. The fancy work included Battenberg, Roman embroidery and Teneriffe and other pieces of intricate design. .

The Art Exhibit consisted of thirteen studies, three from life, five from still life, two from the antique, an illustrated book and two copies. The mediums used for these studies were water colors, oil, charcoal and ink. This was the work of seven pupils from seventeen to twenty years of age and of the highest type of mentally deficient children. The time of study in this class was from one to four years with one hour each school day. 


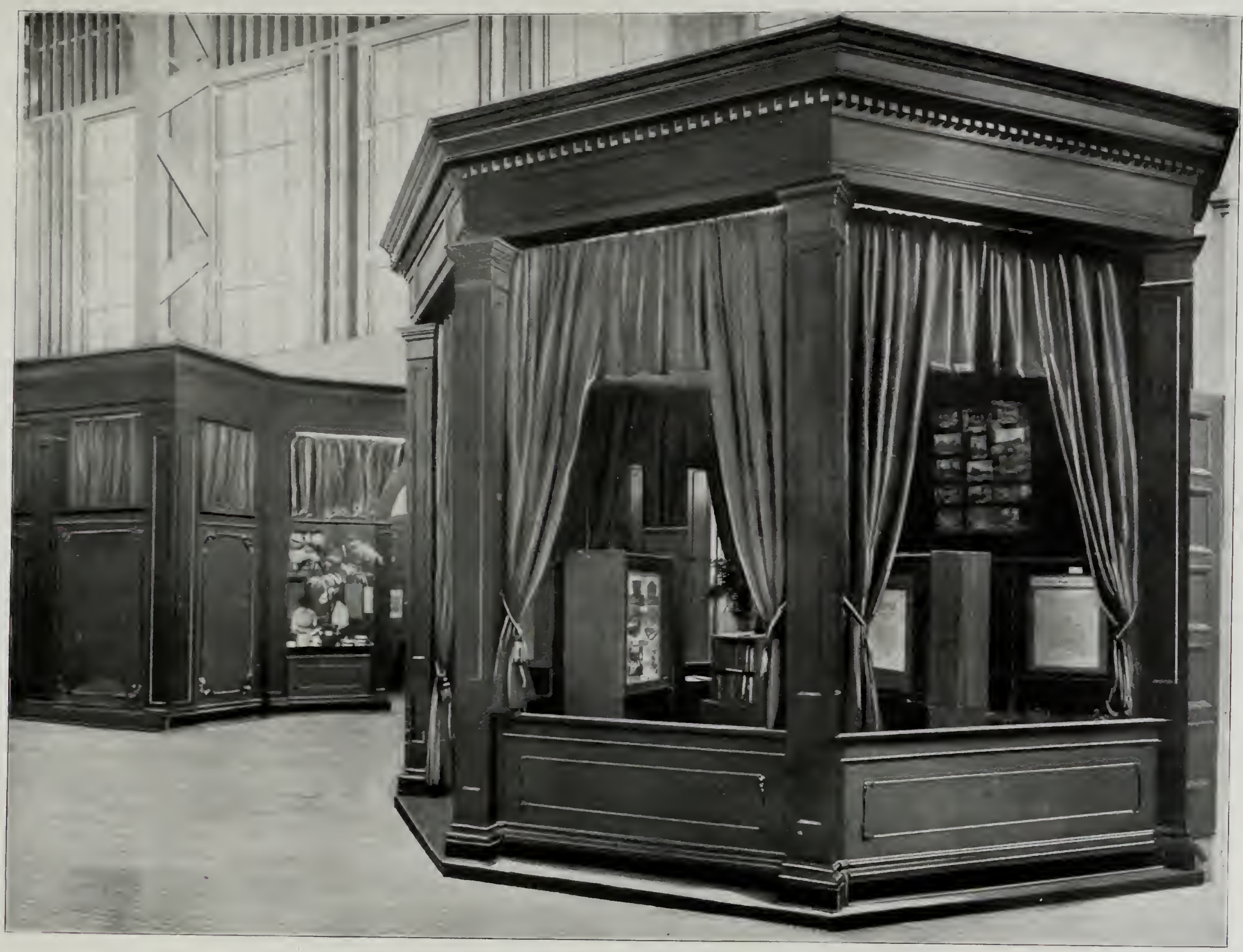




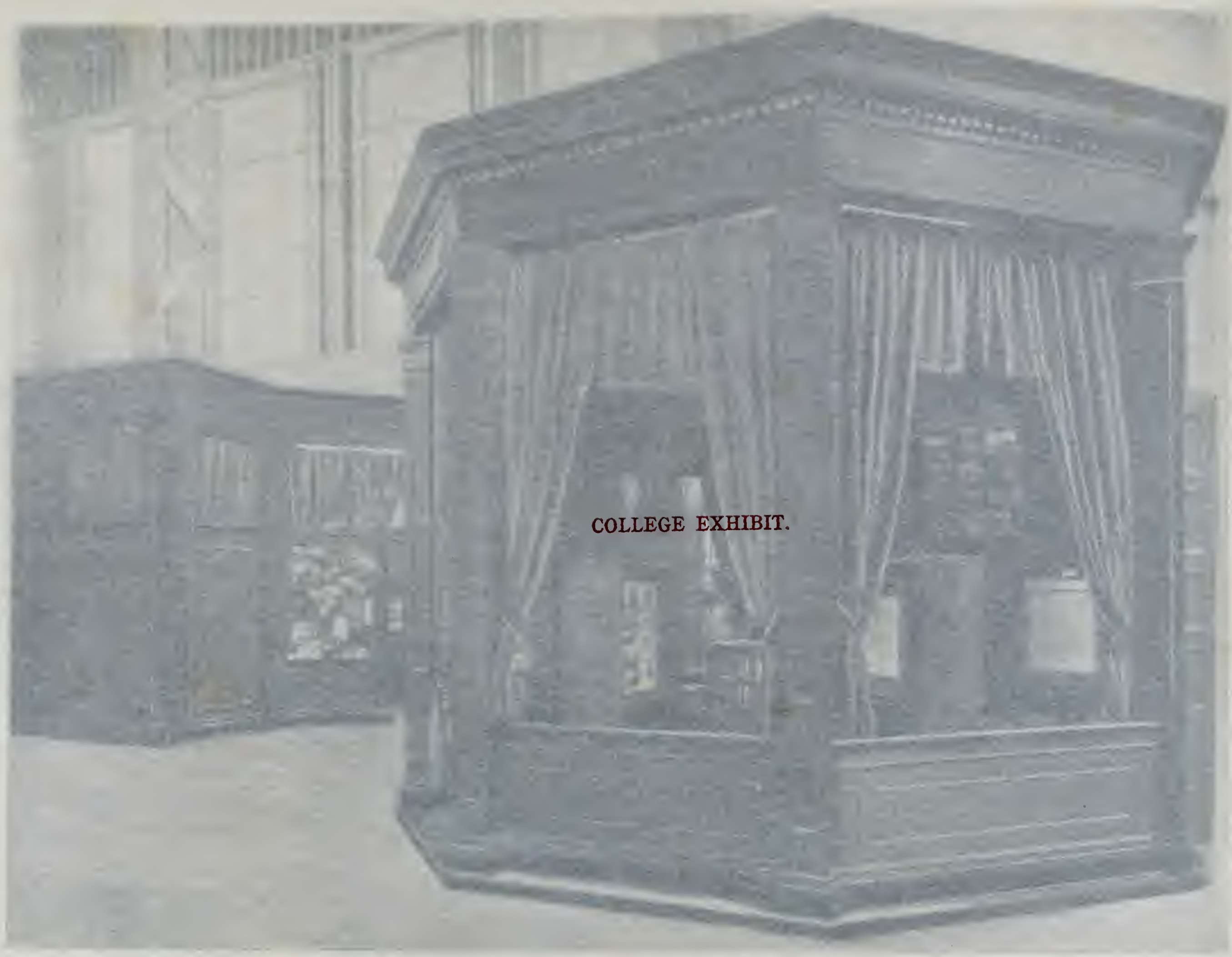


Torchon lace by a girl of nine was exhibited with lace handkerchiefs and turnover collars. Samples showing the stages of progress and different patterns were original with a girl of fourteen. Epileptics and paralytics offered doilies, silk embroidered table sets and centerpieces, sofa pillow tops and handkerchief cases. A picture frame made from crotchet cotton was the work of an inmate of the "Cottage for Adult Females" where classes in needle-craft are held. A Persian rug made on burlap with ingrain rug yarn was the first work of a new inmate. A lace loom was shown with the work in process of construction. The Indian bead work consisted of chains, belts, watch fobs, purses and bracelets made by younger members of the class from eight to sixteen years of age.

When the many thousands of sightseers at the World's Fair read above such exhibits the "Institution for Feeble-Minded Youth," they paused and pictured to themselves a low grade imbecile fit only for asylum care. A second glance at the display would do much to enlighten. These unfortunates in mind may represent the worthiest of parents. The child inheriting from birth an affliction of the mind center, or suffering the blighting effects of a dread disease or painful sickness, may be with the tender care of the state, trainable in manual and even intellectual pursuits, as proved by the very exhibit which caused the passer-by to stop and wonder.

\section{HIGHER EDUCATIONAL EXHIBIT}

One of the attractive features of the Indiana Educational Exhibit was that of the Normal Schools, Colleges and Universities. The space allotted to this exhibit was perhaps the most imposing in the entire building, it being at the junction of three of the long, broad aisles, thus commanding the attention of many visitors.

There was no attempt to make complete exhibits of these institutions. This was due to the lack of available space and funds. However, much was done in the way of excellent photographs of buildings and grounds; interior views of libraries, laboratories and class rooms; bound volumes of written work prepared by students; statements concerning administration and history, etc.

The following is a complete list of institutions represented with exhibits made by each:

\section{GROUP 3-HIGHER EDUCATION. BOOTH 2.}

1. Wabash college, Crawfordsville-Cabinet 1: Photographs of faculty, student body, buildings and equipment; statements

2. Earlham college, Richmond-Cabinet 2-

(a) Photographs of faculty, students, buildings and equipment

(b) Statements of administration and history.

(c) Album of photographs.

3. DePauw university photographic prints.

(a) Photographs of buildings and equipment.

(b) Statistical tables.

4. Butler university, Indianapolis-Cabinet 4-

(a) Photographs of equipment.

(b) Statements of administration.

5. Purdue university, Lafayette-Cabinet 5- 
(a) Photographs of campus, buildings and interiors.

(b) Special exhibit, aisle 2, block 7 .

6. State normal school, cabinets 7 and 8 , photographs of buildings, equipment and faculty; specimens of art work; bound vol-

7. Valparaiso normal school-Cabinet 10: Photographs and specimens of art work; bound volumes of student papers; copies of books written by members of faculty.

8. Danville normal school-Photographs.

\section{JUVENILE COURTS}

In the section devoted to Social Economy, Indiana maintained an exhibit of Juvenile Courts which attracted much attention and called forth much favorable comment. This exhibit was arranged by Judge Geo. W. Stubbs, of the Juvenile Court of Marion County, and was composed of the following items:

Photographs of officials of the Juvenile Court.

The juvenile court law for the state of Indiana.

Statistics.

Photographs, as follows

Showing old way of arresting juvenile offenders.

Showing new way of arresting juvenile offenders.

- Showing old place of confinement for juvenile offenders.

Showing new place of confinement for juvenile ofienders.

Showing interior of court room, court not in session.

Showing interior of court room, court in session.

Showing juvenile offenders being placed on probation.

Showing juvenile offenders being discharged from probation.

Showing juvenile offenders working out fine on wood pile.

Showing various views of institutions other than state institutions to which Marion county juvenile offenders are committed for an indefinite period.

Copies of blank forms, etc.

This exhibit was awarded a gold medal.

\section{HYGIENE}

In the Department of Hygiene, the State Board of Health under the direction of Dr. J. N. Hurty, Secretary, made an exhibit in which was shown:

Copies of the State Health Law.

Health ordinances of cities and towns.

Rules of the state board.

Description of Indiana method of collecting, tabulating, analyzing and publishing of vital statistics, together with a full set of blanks used for such purpose.

Set of pamphlets upon the prevention of consumption, diphtheria, scarlet fever, typhoid fever, smallpox, measles and diarrhoeal diseases, for free distribution.

Set of annual reports of State Board since 1881, the date of its organization.

Copy of book of instructions to state health officers.

Elevations, plans and specifications for sanitary school houses.

Photographs, plans and specifications of sewage disposal plants at Eastern Insane Hospital, Northern Insane Hospital, Boys' Reform School, and Rome City.

Photographs and descriptions of water filtration plants at Terre Haute and Vincennes.

Photographs and descriptions of sanitary plants, paved streets, parks, sewer systems and sanitary work in Indianapolis, Ft.

Wayne, Richmond, Lafayette, South Bend, Terre Haute, Vincennes, and Evansville.

Statistical tables and charts showing deaths from certain causes by months and years.

Typewritten account of methods of doing general sanitary work by the Board. 
This exhibit was awarded two gold medals, one to the State Board of Health and one to the Department of Sanitary Science of Purdue University. A gold medal was also awarded to Dr. Hurty, as collaborator. No greater commendation can be given the State of Indiana in connection with this exhibit than to state that the entire section was placed in the hands of Dr. Hurty, and the collective exhibit of Hygiene for the United States and for the world was prepared under his superintendency, and to the great satisfaction of the Exposition management. He was assisted by Dr. Severance Burrage, of Purdue University, who was in direct charge of the working laboratory of hygiene during the Exposition period, and was also awarded a gold medal as collaborator.

\section{DEPARTMENT OF INSPECTION}

The exhibit installed by the State Department of Inspection, under the direction of D. H. McAbee, Chief Inspector, and David F. Speer, Chief Deputy, was arranged to show the systematic completeness of method adopted for obtaining data and information necessary for the proper enforcement of laws, and was composed of the following items:

1. The Act of 1899 - Concerning labor-providing means for protecting the liberty, safety and health of employes in industrial and mercantile establishments, forbidding the employment of children under the age of fourteen years, and requiring age certificates for minors employed between the ages of fourteen and sixteen; law and blanks.

2. The law providing protection from fire in factories, hotels, schools, sanitariums and all buildings where persons are,employed, roomed or housed above the second story; law, specifications and blanks.

3. For the sanitation of all food producing establishments, etc.; law only.

4. An Act providing for safety appliances on steam boilers and the semi-annual internal inspection of such boilers; law and

5. blanks.

5. The law governing the operation of inland water craft propelled by power and for the carriage of passengers; law and blanks.

6. An Act requiring temporary flooring in buildings in course of construction, three or more stories high; law only.

This exhibit was awarded a gold medal.

\section{THE COLLECTIVE EXHIBIT OF PUBLIC LIBRARIES}

This exhibit was made in the General Education Exhibit and consisted of three principal features.

The first consisted of three winged cabinets exhibiting about two hundred photographic views and floor plans of the Municipal and Institutional Libraries, beside a library map of the State and a table of statistics.

The second consisted of one winged cabinet exhibiting the work of the Public Library Commission, with photographs of typical public libraries and traveling library centers; and two sample traveling libraries.

The third feature was a History of Libraries, a volume of 160 pages giving a brief history and the plan of organization of the several Municipal and Institutional Libraries of the State, with map and statistics. The exhibit was awarded a gold medal on a collective exhibit.

W. E. Henry, State Librarian, had charge of collecting and installing the library exhibit.

\section{AWARDS}

The following awards were made upon Indiana exhibits in education and social economy, based upon a per- 
centage scale prescribed by the general regulations of the Exposition.

(1) Grand prizes- -

(a) Slementary secondary and higher education.

(b) State school administration.

2. Board of State Charities, for collective exhibit.

(2) Gold medals-

1. Laporte high school, exhibit of art instruction.

3. Bard of

4. State of Indiana, collective exhibit of rural schools.

4. State of Indiana, collective exhitidation of rural schools.

5. State of Indiana, exhibit of consolidation

6. Reading circle board. Collective exhibit.

7. Indiana department of inspection, general exhibit.

9. Purdue university. General exhibit.

10. Indiana state board of health, collective exhibit.

11. Department of sanitary science, Purdue university.

12. Juvenile court, Marion county.

13. Dr. J. N. Hurty, collaborator.

14. Professor Severance Burrage, collaborator.

15. Superintendent W. A. Millis, collaborator.

(3) Silver medals -

1. Boards of education of Crawfordsville, Marion, Richmond and Terre Haute, collective exhibit of high schools.

2. Indiana state normal school, general exhibit.

3. School board of Fort Wayne, exhibit of elementary education.

4. School board of Richmond, exhibit of elementary education.

5. School board of Terre Haute, exhibit of elementary education.

6. State of Indiana, collective exhibit of colleges.

7. Culver military institute, exhibit military education.

8. Purdue university, special exhibit.

9. Purdue university, special exhibit.

(4) Bronze medals-

1. School board of Marion, elementary education.

2. Board of education of Franklin county, elementary education.

At least four results of the labor, time and money expended upon this exhibit should be realized:

1. A better definition of the lines and directions of educational offort.

2. A steadying of educational thought.

3. Increase of public interest and faith in public education.

4. The establishment of more definite and higher standards of excellence in the work of the schools.

During the summer hundreds of school officers remained to study for hours and sometimes for several days. And not least gratifying was the large number of Indiana people who came to see the work of their own children and went away with a larger respect for and interest in the work of the public schools. 


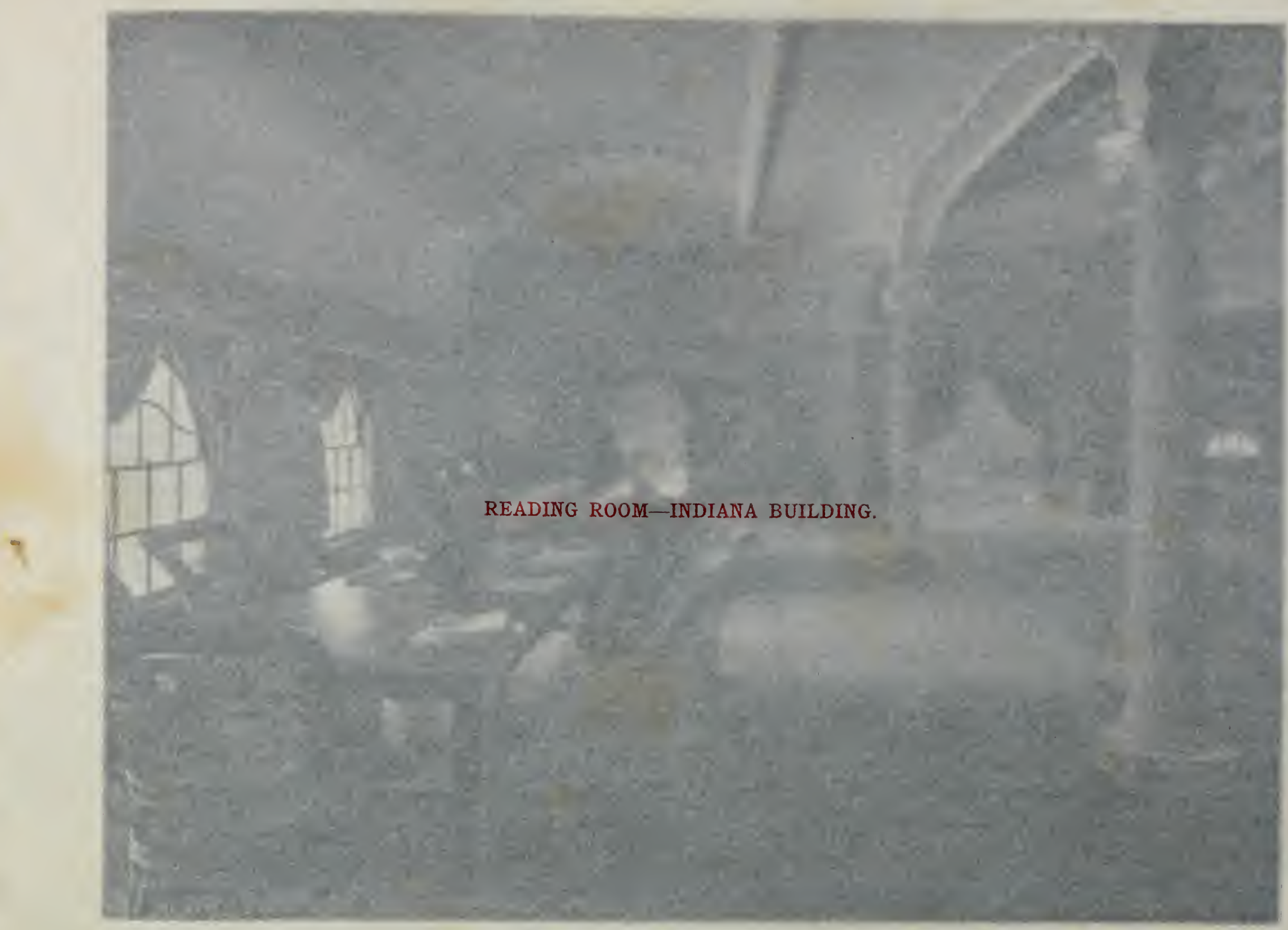




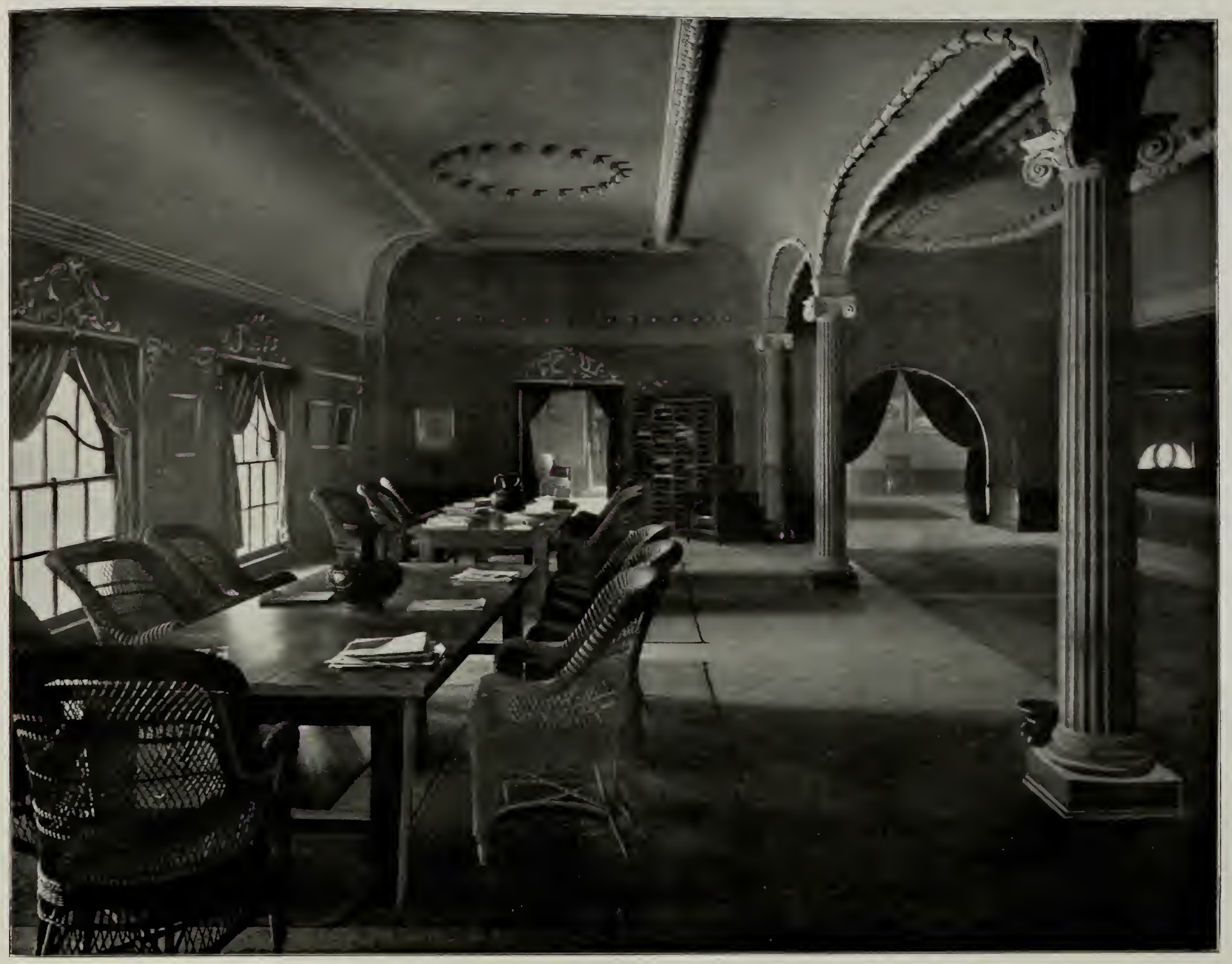




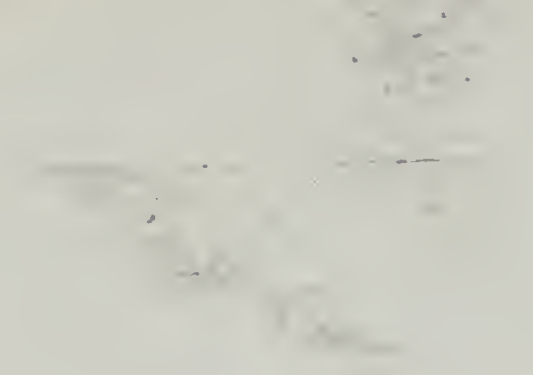




\section{Publicity and Promotion}

This report would be far from complete if it failed to acknowledge to the fullest extent the valuable services rendered by the newspapers of Indiana in creating an interest in the Exposition and the part Indiana was to take in it. Soon after the organization of the Commission, the Committee on Publicity and Promotion organized for a very thorough campaign of exploitation through the press of the state, and employed Mr. Frank W. Spencer to have charge of the literary work, as well as mailing the bulletins and preserving clippings from the newspapers. A bulletin made up of three columns of original matter was printed each week and mailed to a list of 600 newspapers covering every town and city of importance in the state. The newspapers used these articles very freely and gave much space to editorial comment thereon. The assistance rendered by the state press in keeping before the people of the state the doings and purposes of this Commission, cannot be overestimated. These services were gladly rendered without expectation of financial reward. In all, 46 of these weekly bulletins were issued and it is estimated that an aggregate of 25,00 columns of reading matter was furnished by the newspapers before the opening of the Exposition. In addition to the newspapers which used the weekly bulletins, there were a few of the more important papers of the state which requested special articles of greater length and more detail than were supplied by the bulletins. This work was placed in the hands of Mr. Claude S. Watts, and three such articles were prepared by him and given space in a number of publications. As a small acknowledgment to the editors for their valuable services and to slightly express our appreciation of their assistance, we arranged to have June 10 designated as "Special Press Day" at the Exposition. This day was devoted to the entertainment of the editors and every possible courtesy was entended in order that they might enjoy to the fullest extent not only what Indiana had at the Exposition, but the other features of the Fair as well.

\section{Literature and Fine Arts Exhibit}

As already indicated, the Commission dete!mined soon after its organization that the position of the state in literature and the fine arts was worthy of special representation at the Fair. To this end the entire subject was referred to a committee consisting of C. C. Shirley, Chairman, S. B. Fleming and W. W. Wicks.

It was found that no separate recognition of the states, as such, would be given by the general management of the Exposition in the Department of Fine Arts; the classification of exhibits in that department was limited to the various nations, no reference being had to state lines or other political subdivisions. Under these conditions, the first problem which the Committee was called upon to solve was how to best present in concrete form the literary and artistic advancement of our people. After full consideration, it was determined to encourage individual artists of the state, as far as possible, to exhibit their work in competition with the world in the Palace of Fine 
Arts, and, in addition, to invite them to co-operate with the Commission in making a distinctive Indiana exhibit of fine arts in the Indiana State Building. To this feature it was proposed to join a complete exhibit of the meritorious literary productions of Indiana authors.

The Committee at once put itself into communication with representative artists and authors of the state and it is gratifying to say that their response was immediate and cordial. Of the pictures offered for exhibition in the Palace of Fine Arts, nineteen works of Indiana artists were accepted. Only one other Western state was represented by so large a number in the general exhibit. Of those exhibiting in the Palace of Fine Arts, Mr. Wm. Forsyth was awarded two medals, one of silver and the other of bronze, and Mr. J. Ottis Adams was awarded a bronze medal.

In order that a high standard of artistic excellence should be assured in the exhibit at the Indiana Building, a committee of well known artists was appointed and vested with plenary power to pass on all work that might be offered. Messrs. J. Ottis Adams, T. C. Steele, R. B. Gruelle, Wm. Forsyth, Otto Starke and J. E. Bundy comprised this committee and rendered valuable assistance to the Commission in collecting and installing the exhibit. Of the many pictures submitted to this eminent jury of artists, seventy-eight were accepted and adorned the walls of the Indiana Building during the period of the Exposition. The pictures thus assembled did not participate in any competitive art exhibit, but constituted a most attractive decorative feature of the Indiana Building, and, as the Commission is encouraged to believe, did much to emphasize the high position to which we have attained in the world of art.

A full list of the paintings thus exhibited, together with the names of the respective artists, is as follows:

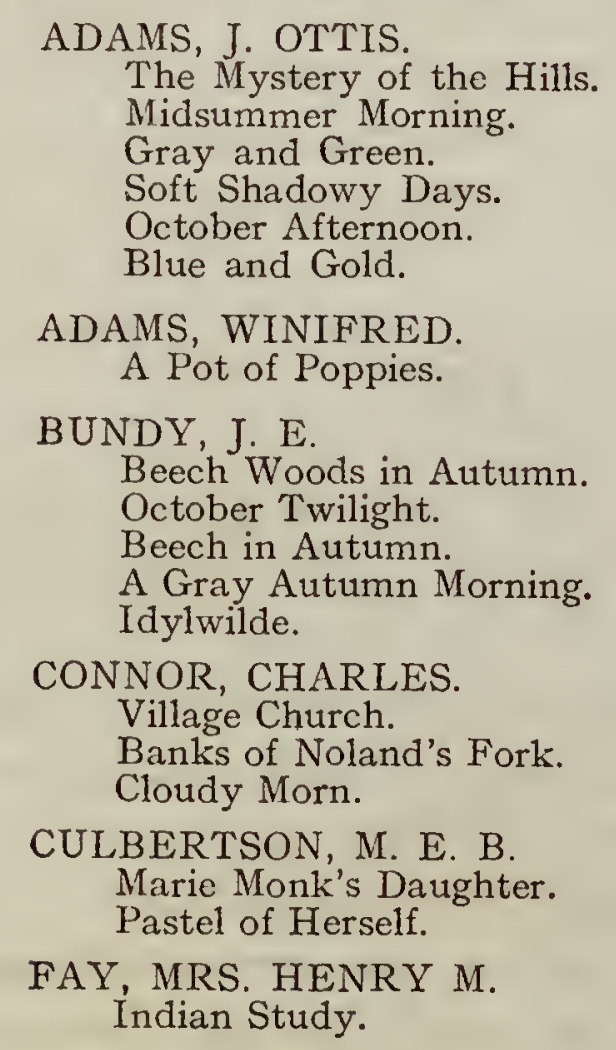

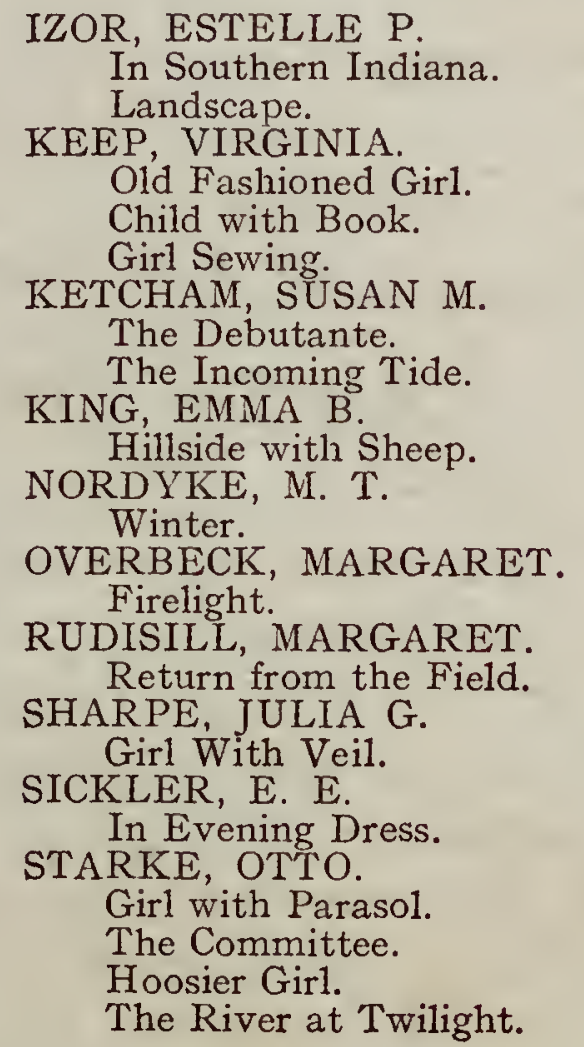




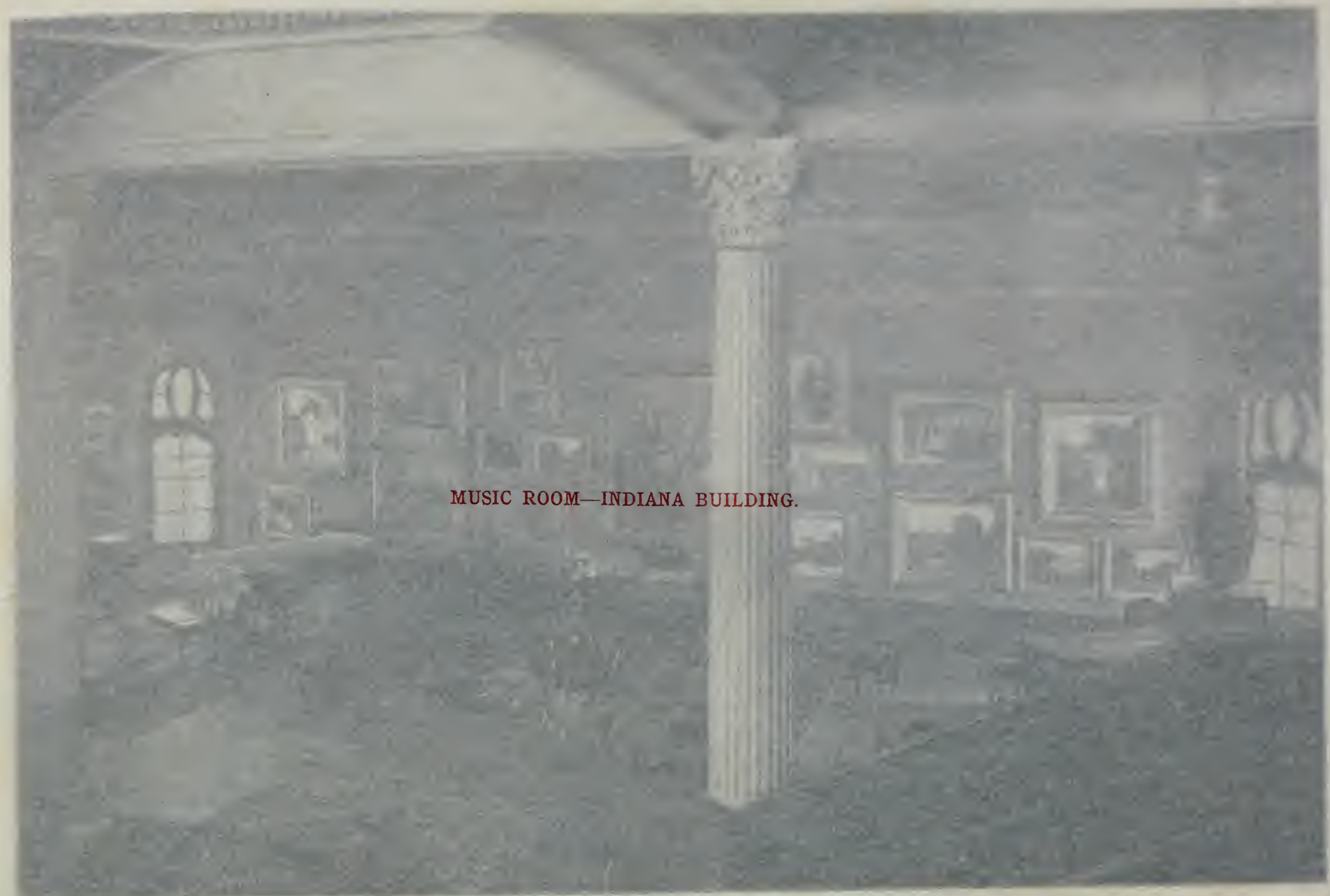




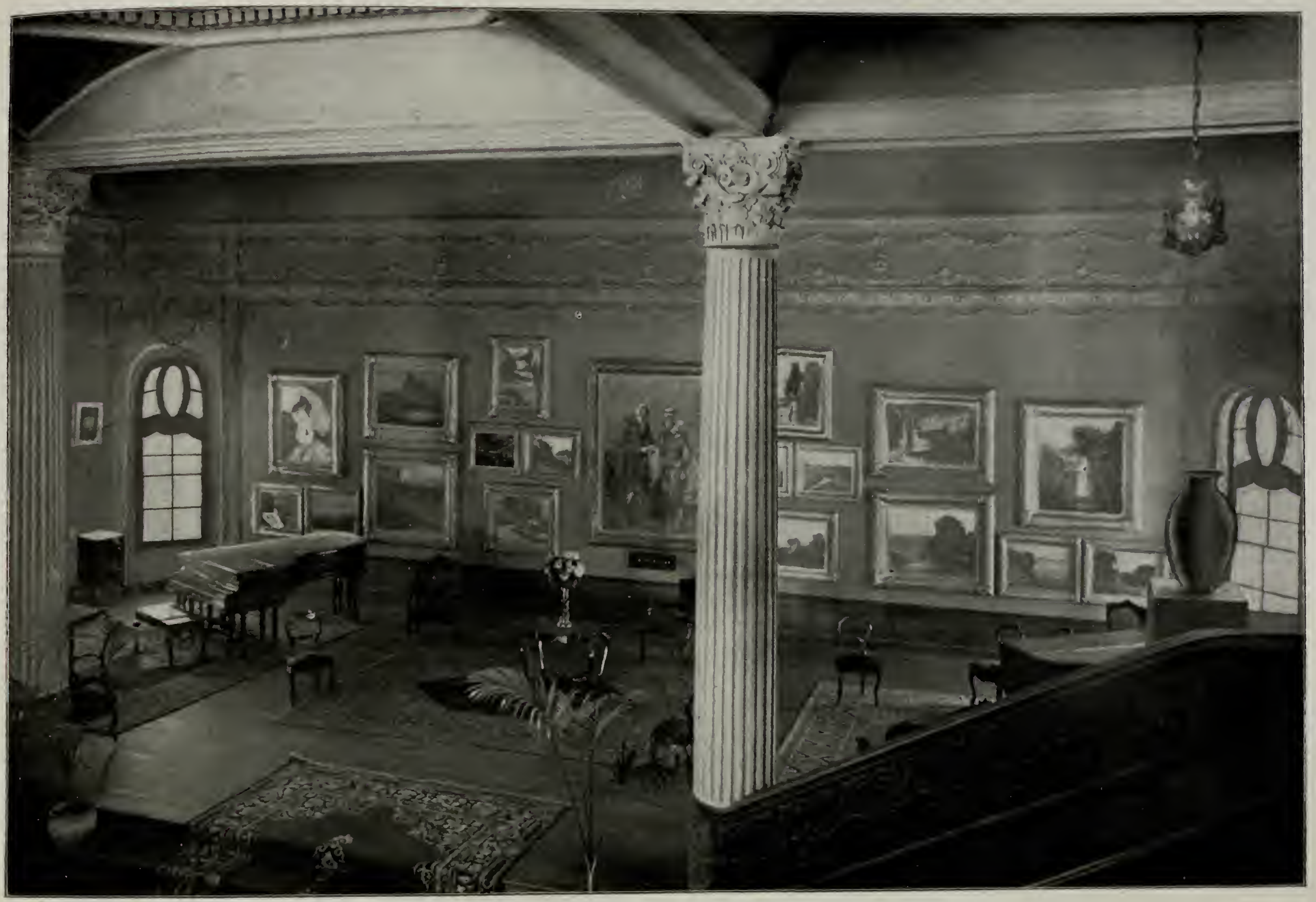


August Afternoon.

Fisher Boy.

STEELE, T. C

The Ravine.

Blue and Gold Mill at Brookville.

October Morning

Blue Hills, October.

Low Tide, Oregon Coast.

Late Winter Afternoon.
TAGGART, LUCY.

Shaker Sister.

Kentucky Pasture.

Colonel C.

Jeanette.

TROBAUGH, R. B

Hickories in Autumn.
Rock and Waves

WEISFNBERGER, MRS, SADIE E. In the Park.

WILSON, MRS. L. A.

In Columbia Place.

ZARING, LOUISE E.

Woman Knitting.

Still Life.

Study in Green and Red.

It is believed that the collection of literary and scientific works by Indiana authors placed in the library of the Indiana Building was the most complete ever assembled. It included practically every literary production of permanent value that has been contributed to the world of letters by an Indiana author. Many original manuscripts by some of the most eminent Indiana writers added much to the interest of the exhibit, while the walls of the room were adorned by the portraits of those whose literary genius has shed imperishable lustre on the name of the state. The entire exhibit of literature and fine arts installed by the Commission in the Indiana Building, was, throughout the Fair, in charge of Mrs. May Warthin Dunn, the efficient Superintendent of the department.

\section{BOOKS BY INDIANA AUTHORS}

Below appears a complete list of books and their authors, also a list of original manuscripts, drawings and illustrations:

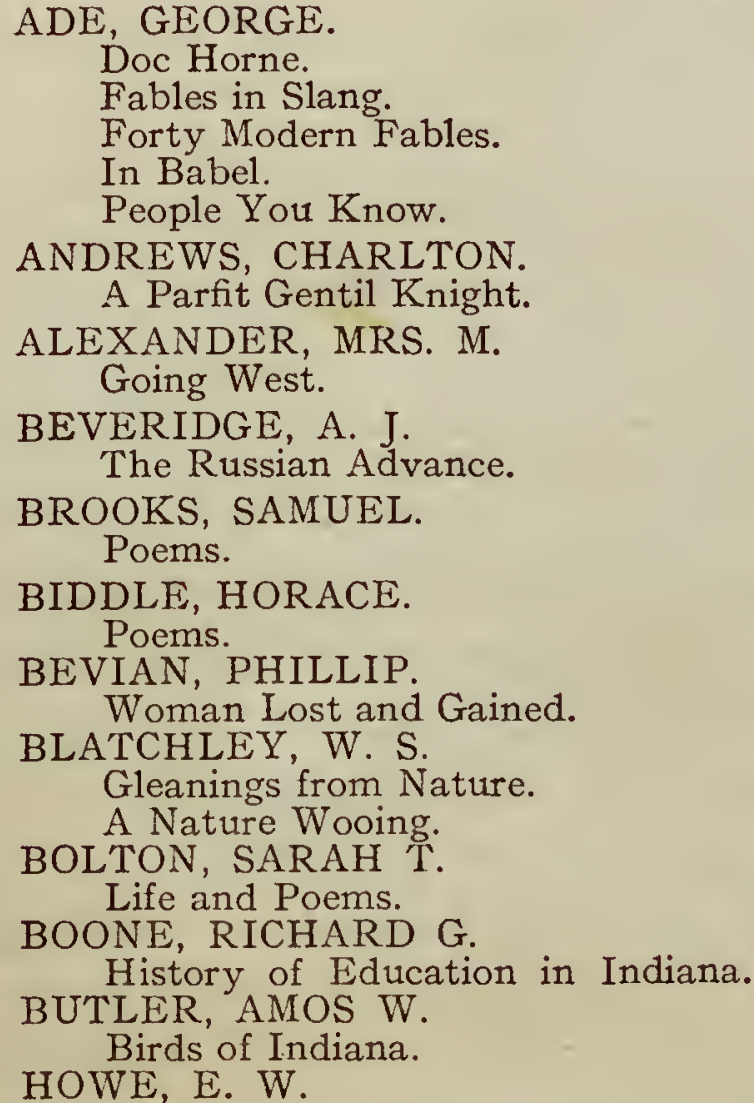

Stories of a Country Town.

JENKINSON, ISAAC.

Aaron Burr.

JOHNSON, R. U

Poems.

JOHNSTON, ANNA FELLOWS.

Asa Holmes.

The Little Colonel at Boarding School.

Little Colonel's Hero.

The Little Colonel's Holiday.

The Little Colonel's House Party.

Little Colonel Stories.

CATHERWOOD, MARY $\mathrm{H}$.

Lazarre.

White Islander.

Story of Tonty.

Romance of Dollard.

CHITWOOD, M. LOUISA. Poems.

COFFIN, CHAS. E.

The Gist of Whist.

CONKLIN, JULIA S.

Young People's History of Indiana.

CALLAHAN, JAMES MORTON.

Neutrality of American Lakes.

Cuba and International Relations.
Diplomatic History of the Southern Confederacy.

COULTER, JOHN M.

Plant Relations.

Plant Structures.

COX, MILLARD F.

(HENRY SCOTT CLARK).

The Legionaries.

CUMBACK. WILL.

Lectures and Addresses.

DILLON, JOHN B.

History of Indiana.

DUNN, J. P.

Indiana.

Massacres of the Mountains.

McCUTCHEON, GEO. B.

Graustark.

Castle Cranycrow.

Sherrods.

MAJOR, CHARLES.

Bears of Blue River.

Dorothy Vernon.

Forest Hearth.

When Knighthood was in Flower.

JOHNSTON, ANNA FELLOWS and

BACON.

Albian Fellows.

Songs Ysame.

JORDAN, D. S. and 
EVERMANN, B. W. American Food and Game Fishes.

JULIAN, GEO. W.

Life of Joshua Giddings.

KROUT. CAROLINE.

(CAROLINE BROWN).

On the We-a Trail.

KROUT, MARY $\mathrm{H}$.

Hawaii and a Revolution.

A Looker on in London.

LOCKWOOD, GEO. B.

The New Harmony Communities.

VAWTER, CLARA and WILL.

The Rabbit's Ransom.

VOORHEES, DANIEL W.

Forty Years of Oratory.

WOOD, WILLIAM ALLEN. Sons of the Revolution.
WOODBURN, JAMES A. Political Parties and Party ProbPems in United States.

WOODS, ALICE.

Edges.

MILLER, ELIZABETH The Yoke.

MILLER, JOAQUIN.

Poetical Works.

Memorie and Rimes.

True Bear Stories.

MOODY, WM. V.

Poems.

History of English Literature.

MOODY, MARTHA LIVINGSTON. Tragedy of Brinkwater.

MATHEWS, JAMES NEWTON. Poems.

MUNDAY, MURANIA.

Lyrics.

ORIGINAL MANUSCRIPTS
MONCRIEF, JOHN W.

History of the Christian Church.

NICHOLAS, ANNA.

An Idyl of the Wabash.

NICHOLSON, MEREDITH.

The Main Chance.

The Hoosiers.

WALLACE, SUSAN E.

The Storied Sea.

Along the Bosphorus.

The Repose of Egypt.

WALLACE and HALSTEAD. Lives of Harrison and Reid.

WALLACE, LEW.

Ben Hur.

A Fair God.

Prince of India.

WOOLLEN, W. W Early Indiana.
WALLACE, GENERAL LEW, EGGLESTON, EDWARD, THOMPSON, MAURICE, HARRISON, BENJAMIN, NICHOLSON, MEREDITH, MAJOR, CHARLES,
WALLACE, MRS. LEW, ADE, GEORGE,

MCCUTCHEON, GEORGE BARR, PORTER, GENE STRATTON,

STEIN, EVALEEN,

MILLER, ELIZABETH.

\section{ORIGINAL DRAWINGS}

WILL VAWTER, illustrating, Riley's "When the Frost is on the Punkin," and "His Pa's Romance." VIRGINIA KEEP, illustrating Evaleen Stein's "Troubadour Tales."

Illustrating "LAZARRE," by Mary Hartwell Catherwood.

Illustrating "OLD SWEETHEART OF MINE," by James Whitcomb Riley.

\section{Department of Women's Work}

When the Commission was organized it was supposed that the general Exposition management would create a department and provide a building that should be especially devoted to the representation of these arts and crafts which are of special interest to women. The World's Columbian Exposition and other similar fairs had adopted this plan, and its apparent success warranted the assumption that a like course would be followed at St. Louis. Accordingly, a Department of Women's Work was created by the Indiana Commission and given in charge of a committee consisting of C. C. Shirley, Chairman, W. W. Wicks, and Frank C. Ball. Almost immediately after its appointment the Committee was advised that the plan of the Louisiana Purchase Exposition did not contemplate the exploitation of women's work, as such, and that all such exhibits would be received and shown in the Depart- 


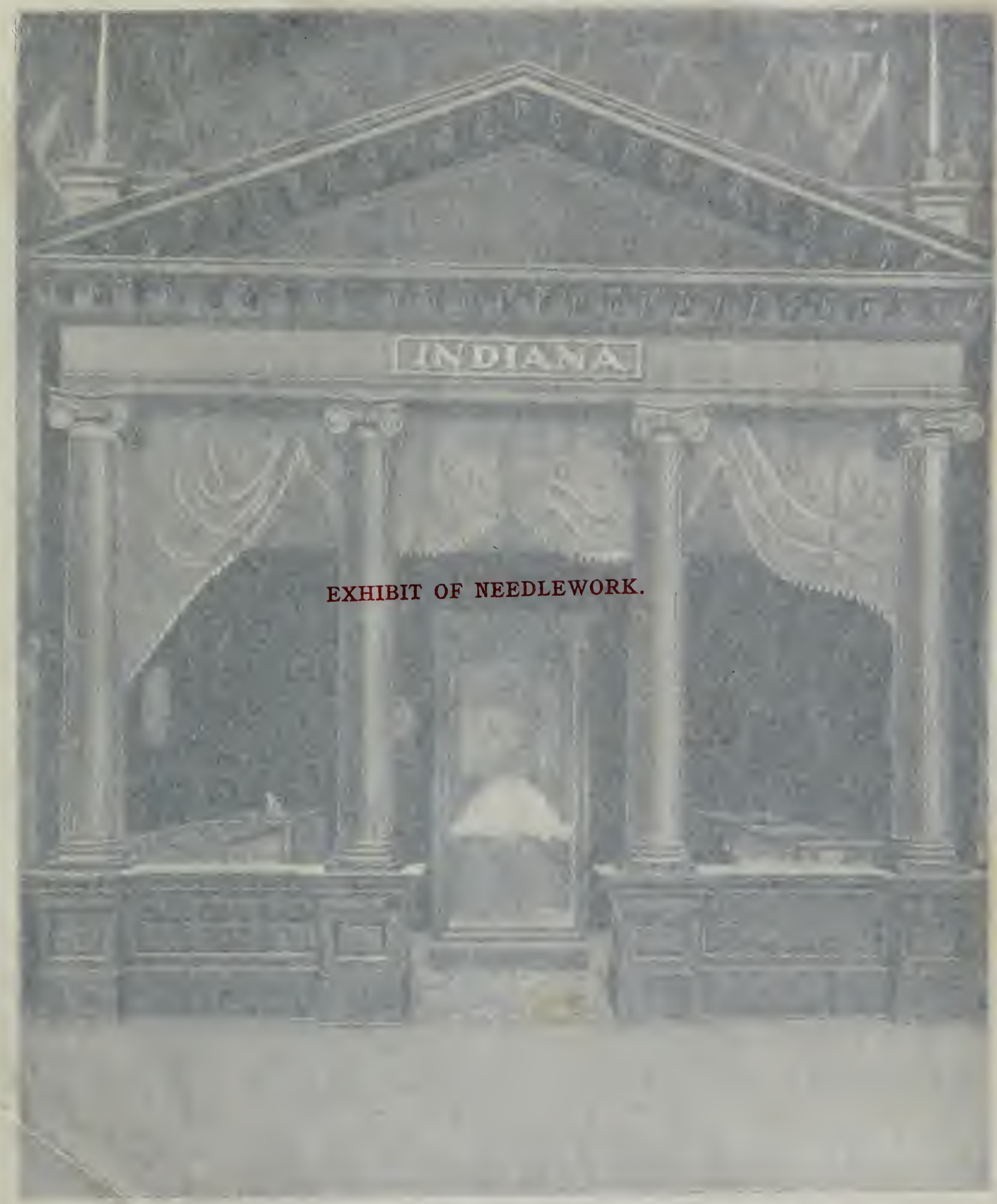




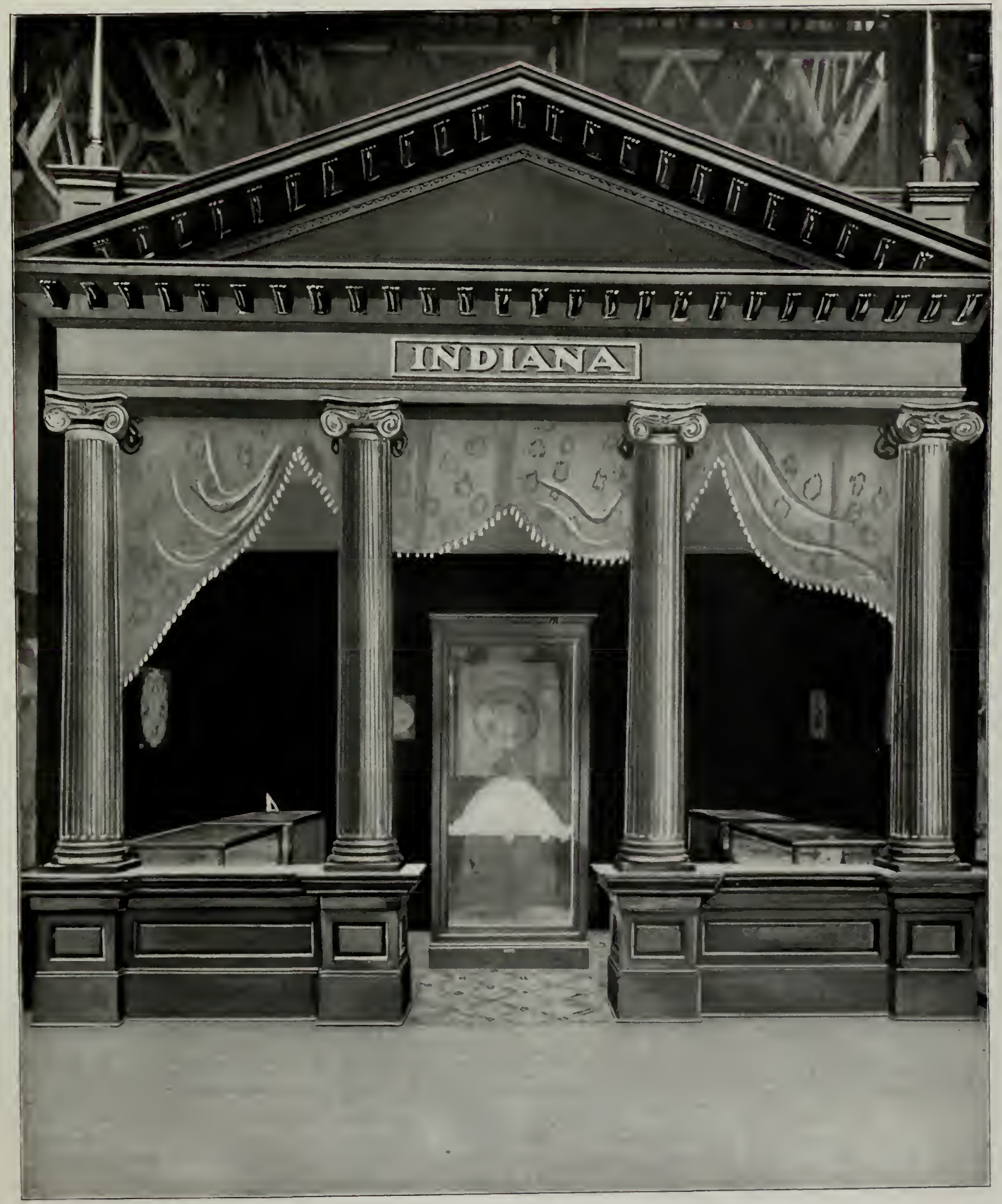


ments of Manufactures and Varied Industries without reference to the sex of the exhibitor. No provision was made for grouping such exhibits with reference to the States from which they were received, and the Committee was further informed that each exhibitor would be expected to apply for space on her own account and bear the expense of installation and maintenance. These conditions were of course prohibitory unless the state should assume the burden of affording facilities to those who desired to exhibit embroideries, decorated china and other products of women's skill.

The number of letters received by the Committee from women in all parts of the state, inquiring as to the conditions under which the work of their hands might be exhibited at the Fair, showed conclusively that the interest in the subject was quite general. In obedience to this very considerable demand it was finally determined by the Indiana Commission, with the approval of the Department of Manufactures, that booths should be erected and maintained at the expense of the state for the reception and display of women's work, which, however, it was found necessary to limit to ceramics and textile fabrics. The Committee in charge of this department was fortunate in securing the services of Mrs. W. L. Berryman, of Tipton, as Superintendent. Under her immediate supervision'a very excellent exhibit of embroideries and laces was installed in the Manufactures Building, and an equally attractive and meritorious exhibit of decorated china was placed in the Palace of Varied Industries. Each of these exhibits was housed in an artistic booth provided with suitable showcases and other facilities for the proper display of the work contributed by the women of the state.

The architecture of the booths was similar, each being of simple classic design; that in the Department of Manufactures being a fine representation of mahogany, while the decorated china booth was finished delicately and effectively in white enamel and gold.

The Superior Jury of hte Exposition gave twenty-three awards to this exhibit, including two grand prizes to the State as collaborator; seventeen of these were accorded to the Division of Textile Fabrics and six to that of Decorated China. Each article shown in this department constituted a separate exhibit and was marked with the name and address of the owner. The Commission, however, paid the expense, not only of maintaining the exhibit, but of shipment and re-shipfent of each article, and insurance on the same while in its charge.

The following is a complete catalogue of the exhibits in the Department of Women's Work, with the names of the respective exhibitors:

\section{TEXTILE FABRICS}

Krame, Mrs. Tyler; Teneriffe Centerpiece. Miner, Miss Fannie; Needle Point Lace.

Miner, Miss Fannie; Duchesse Lace.

Miner, Miss Fannie; Point Lace Butterfly.

Shaw, Mrs. K. N. ; Needle Point Lace Collar.

Shaw, Mrs. K. N.; Needle Point Lace Fan.
Williamson, Miss Mary A.; Centerpiece, Net and Embroidery.

Williamson, Miss Mary A.; Centerpiece Persian.

Williamson, Miss Mary A.; Mother of Pearl Centerpiece.

Williamson, Miss Mary A.; Mount Mellick Centerpiece. 
Williamson, Miss Mary A.; Moss Centerpiece. Williamson, Miss Mary A.; Mother of Pearl Centerpiece.

Rinard, Mrs. J. W.; Needle Picture.

Murphy, Geo.; Center-piece, Roses.

Lantz, Mrs. L. G.; Applique Collar.

Lantz, Mrs. L. G.; Kerchief Lace.

Lantz, Mrs. L. G.; Kerchief Lace.

Lantz, Mrs. L. G.; Tab Collar.

Lantz, Mrs. L. G. ; Battenburg Table Cover.

Lantz, Mrs. L. G.; Two 'Toned Battenburg.

Lantz, Mrs. L. G.; Drawn Work.

Lantz, Mrs. L. G.; Mount Mellick.

Lantz, Mrs. L. G.; Lunch Cloth.

Lantz, Mrs. L. G.; Centerpiece, Linen.

Lantz, Mrs. L. G.; Centerpiece, Strawberry.

Lantz, Mrs. L. G. ; Centerpiece, Poppy.

Lantz, Mrs. L. G.; Centerpiece, Pansy.

Lantz, Mrs. L. G.; Centerpiece, Butterflies.

Lantz, Mrs. L. G.; Centerpiece, Peonies.

Lantz, Mrs. L. G. ; Centerpiece, Ruman.

Lantz, Mrs. L. G. ; Centerpiece, Persian.

Lantz, Mrs. L. G.; Centerpiece, Poppy.

Dwyer, Mrs. James; Centerpiece, Lace Braid.

Rush, Mrs. John E. Lunch Cloth.

Rush, Mrs. John E.; Cape Collar.

Rush, Mrs. John E.; Stole Collar.

Mount Mellick Club of Terre Haute;

Charles, Miss Lula; 1 Tea Set, 6 pieces.

Charles, Miss Lula; 1 Berry Set, 7 pieces.

Hadley, Miss Alice Ross; Vase.

Hadley, Miss Alice Ross; Vase.

Hadley, Miss Alice Ross; Vase.

Hadley, Miss Alice Ross; Vase, Iris.

Hadley, Miss Alice Ross; Bonbon Box.

Hadley, Miss Alice Ross; Fruit Bowl.

Moore, Mrs. Deck; Vase.

Moore, Mrs. Deck; Plate.

Moore, Mrs. Deck; Plate.

Minor, Miss Mary J.; Punch Bowl and Base.

Minor, Miss Mary J.; 6 Punch Cups.

Day, Mrs. W. S.; Flemish Tank, Glass.

Day, Mrs. W. S.; Half-dozen Champagne Glasses.
Rush, Mrs. John E.; Bonne Femme Curtain.

Rush, Mrs. John E.; Bonne Femme Curtain.

Rush, Mrs. John E. ;Sofa Pillow Top.

Rush, Mrs. John E.;Handkerchief.

Evans, Mrs. Chas.; Center-piece.

Murphy, Mrs. John H.; Centerpiece, Peony.

Craft, Mrs. Esther; Point Lace Stole Collar.

Gifford, Mrs. M. R.; Battenburg Lace.

Major, Mrs. Wm. S.; Embroidered Table Cloth.

Major, Mrs. Wm. S. ; Embroidered Table Cloth.

Harding, Mrs. W. T.; Dresser Cover.

Bartholomew, Mrs. Homer; Tatted Collar and Turnover.

Nash, Mrs. L. B.; Table Center.

Nash, Mrs. L. B.; Sideboard Set.

Nash, Mrs. L. B. ; Roman Centerpiece.

Nash, Mrs. L. B. ; Battenburg Table Cover.

Thompson, Mrs. W. E.; Point Lace Handkerchief.

Tull, Miss Minnie M.; Battenburg Center-piece.

Tull, Miss Minnie M.; Point Lace Handkerchief.

Russell, Mrs. Will E.; Lunch Cloth.

Olivia, Mother; Tray Cloth.

Olivia, Mother; Centerpiece.

Olivia, Mother; Embroidery Picture.

Olivia, Mother; Embroidery Picture.

Kinnison, Mrs. Nettie N.; Drawn Doiley.

Kinnison, Mrs. Nettie N.; Battenburg Dress Front.

\section{DECORATED CHINA}

Day, Mrs. W. S.; 1 Bonbon Box, China.

Day, Mrs. W. S. ; 1 Card Box.

Day, Mrs. W. S. ; 1 Vase.

Day, Mrs. W. S. ; 1 Candelabrum.

Day, Mrs. W. S.; 1 Jar, Pottery, 13x4 1-2.

Day, Mrs. W. S. ; 1 Ten-inch Plate.

Day, Mrs. W. S. ; 1 Jar, $5 \times 5$.

Day, Mrs. W. S. ; 1 Vase, $4 \times 5$.

Day, Mrs. W. S.; 1 Loving Cup, $61-2$ x 6 1-2.

Day, Mrs. W. S.; 1 Vase, Pottery, $13 \times 4$ 1-2.

Day, Mrs. W. S.; 3 Small Vases, Pottery.

Bruner, Mrs. Grace Newell; Creamer and Sugar.

Bruner, Mrs. Grace Newell; Placque.

Bruner, Mrs. Grace Newell; Vase.

English, Mrs. W. B.; Portrait, Gentleman.

English, Mrs. W. B.; Fancy Head (Odetta). 


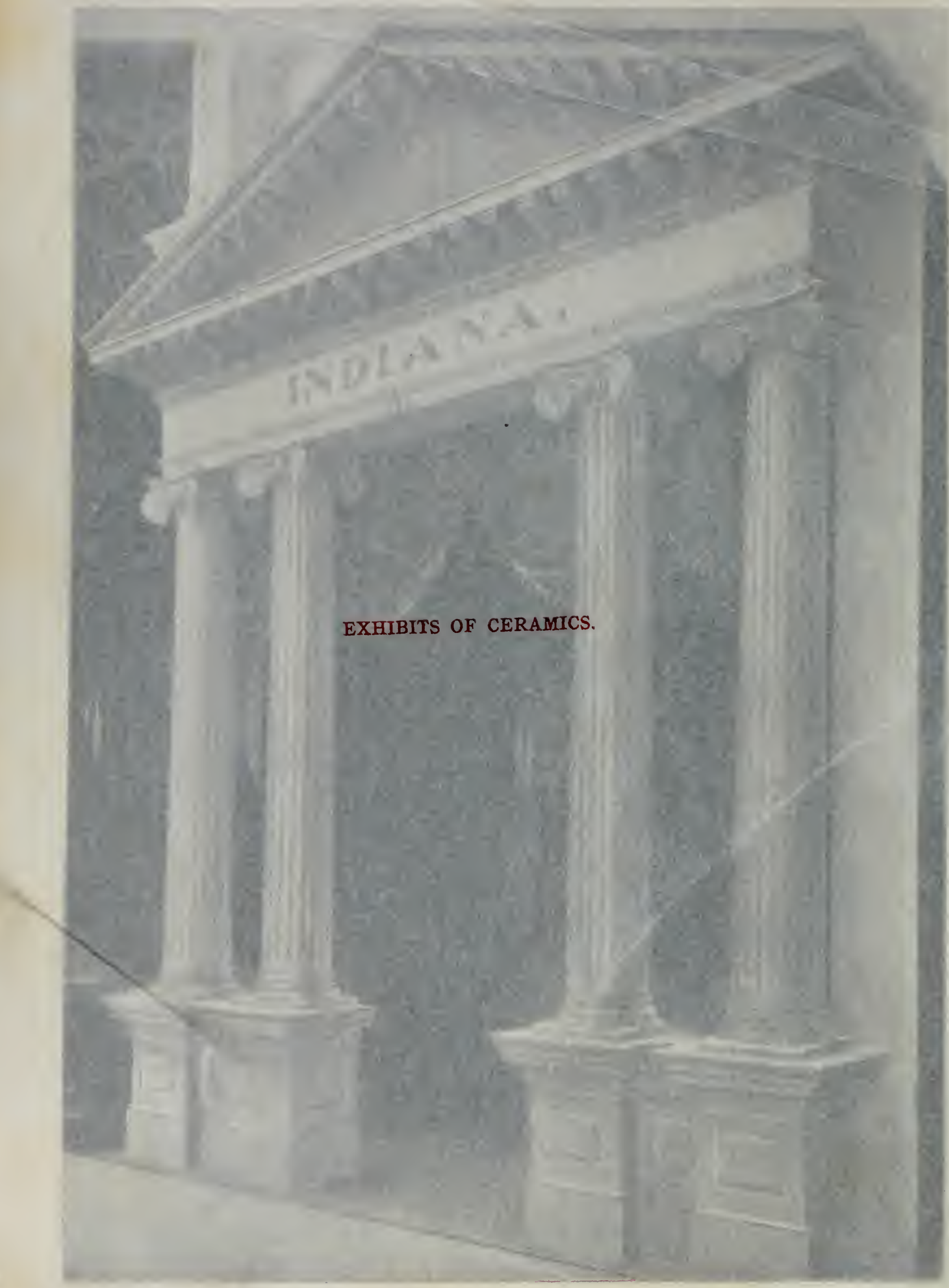




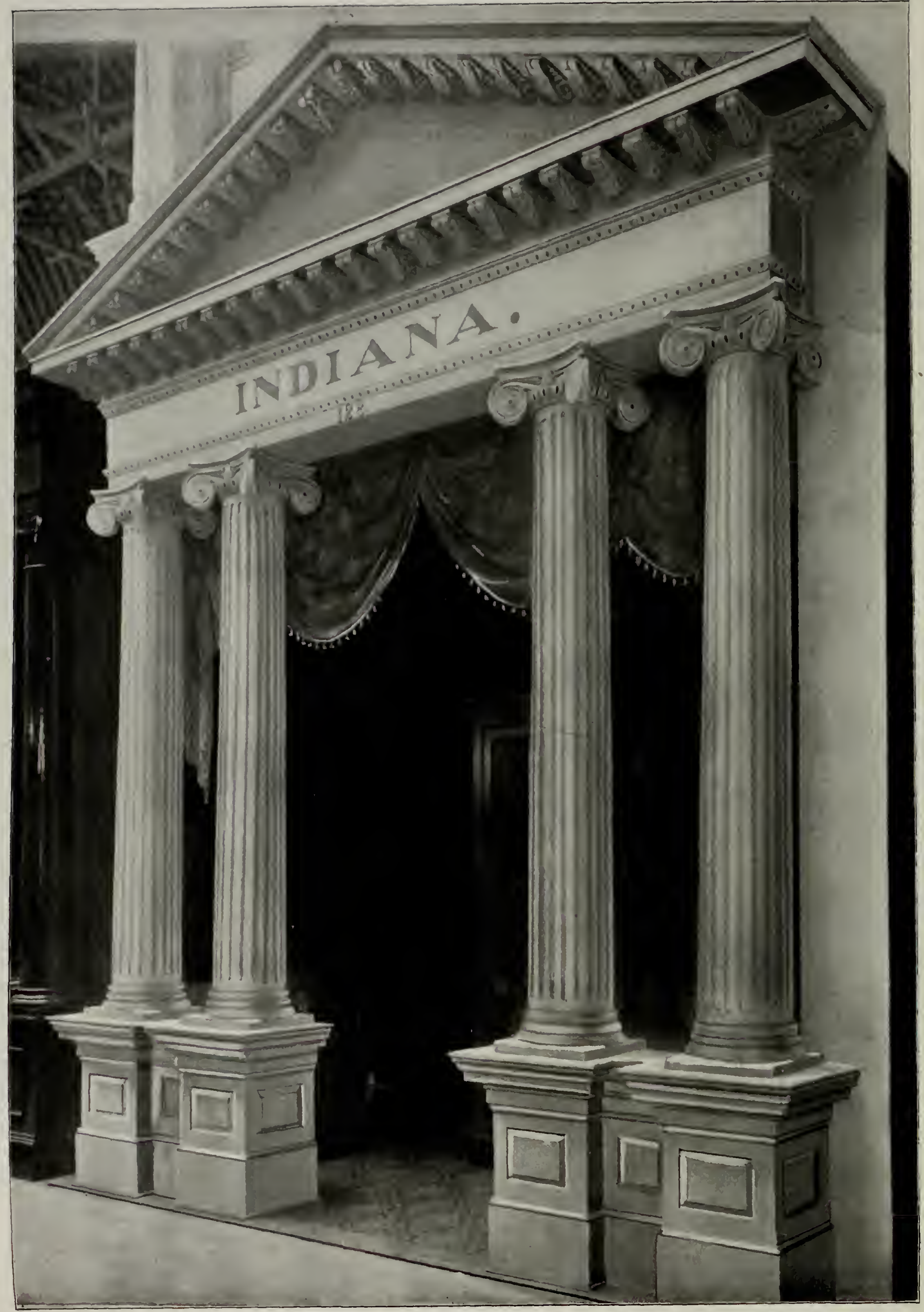


English, Mrs. W. B.; Turkish Coffee Pot.

Whitridge, Miss Bessie; Porcelain Slab, "In The Cloister."

Conard, Miss Katharine; Persian Vase.

Conard, Miss Katharine; Plate.

Conard, Miss Katharine; Card Box.

Fleming, Mrs. Laura Georgas; 1 Miniature on Ivory.

Fleming, Mrs. Laura Georgas; 1 Miniature on Ivory.

Stubbs, Mrs. L. D.; 1 Placque, Roses.

Stubbs, Mrs. L. D.; 1 Placque, Madame Recamier.

Stubbs, Mrs. L. D. ; 1 Vase, Spindel Scene.

Taylor, Miss Myrtle L.; Placque.

Taylor, Miss Myrtle L.; Vase.

Palmer, Mrs. H. V. Y.; Vase, Psyche.

Palmer, Mrs. H. V. Y.; Vase, Roses.

Palmer, Mrs. H. V. Y.; Vase, Iris.

Palmer, Mrs. H. V. Y.; Placque, Morning Glories.

Marsh, Mrs. Susan R.; Portrait.

Marsh, Mrs. Susan R.; Portrait.

Marsh, Mrs. Susan R.; Portrait.

Marsh, Mrs. Susan R.; Portrait.

Marsh, Mrs. Susan R.; Portrait.

Marsh, Mrs. Susan R.; Portrait.

Marsh, Mrs. Susan R.; Portrait.

Marsh, Mrs. Susan R.; Portrait.

Marsh, Mrs. Susan R.; Portrait.
Olivia, Mother M.; Slab, Immaculate Conception. Olivia, Mother M.; Vase, Guardian Angel.

Olivia, Mother M.; "Ecce Homo."

Commons, Olive W.; Trillium Vase.

Commons, Olive W.: Geranium Plate.

Orndorff, Mrs. Amelia L.; "Irish Spinning Wheel."

Orndorff, Mrs. Amelia L.; Indian, Red Cloud.

Orndorff, Mrs. Amelia L.; "Rembrandt."

Orndorff, Mrs. Amelia L.; "Vanity."

Baker, Miss Pearl; Lemonade Pitcher

Punsch, H. O.; Portrait.

Punsch, H. O.; Vase.

Punsch, H. O.; Tankard.

Punsch, H. O.; Small Vase.

Punsch, H. O.; Small Tankard.

Charles, Miss Lula; Jardiniere.

Charles, Miss Lula; Claret Pitcher.

Charles, Miss Lula; Plate, Monogram.

Charles, Miss Lula; Plate, Conventional.

Charles, Miss Lula; Tea Set.

Charles, Miss Lula; Sandwich Tray.

Charles, Miss Lula; Jewel Plate, China

Moore, Mrs. Deck; 4 Plates.

Moore, Mrs. Deck; Tea Set.

Moore, Mrs. Deck; Nut Bowl.

George, Miss Effie.

\section{AWARDS ON TEXTILE FABRICS}

GROUP 58.

Name.

Residence.

Exhibit.

Award.

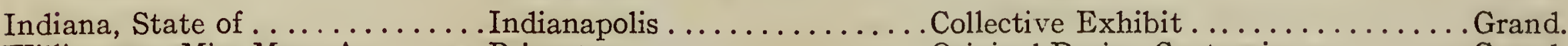

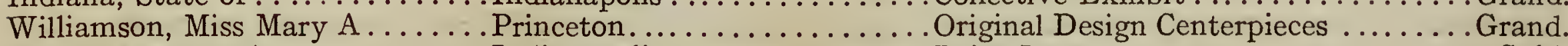
Miner, Miss Fannie............ Indianapolis . ............ Point Lace .................... Gold.

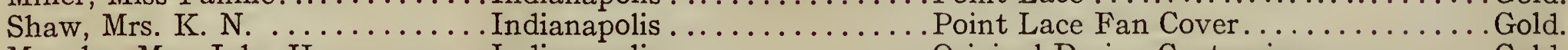
Murphy, Mrs. John H......... Indianapolis ............. Original Design Centerpiece .........Gold. Nash, Mrs. L. B...........Tipton............... Table Center in Chrysanthemums. ..... Gold.

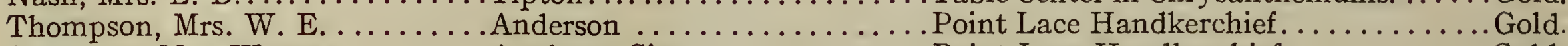
Chapman, Mrs. Wyota, ........Appleton City . . . . . . . . . Point Lace Handkerchief............. Gold. St. Francis, Sisters of ......... Oldenburg ............. Centerpiece, Tray Cloth and Needlework Pictures .................. Silver.

Craft, Mrs. Esther . . . . . . . . . . Indianapolis . . . . . . . . . . . . Point Lace Stole Collar............. Silver. Lantz, Mrs. L. G. ............ Indianapolis ............. Battenburg Centerpiece ........... Silver.

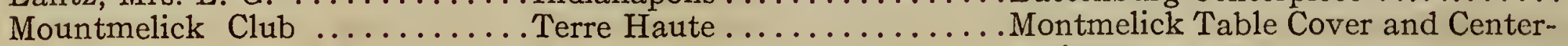
pieces..................... Silver. 


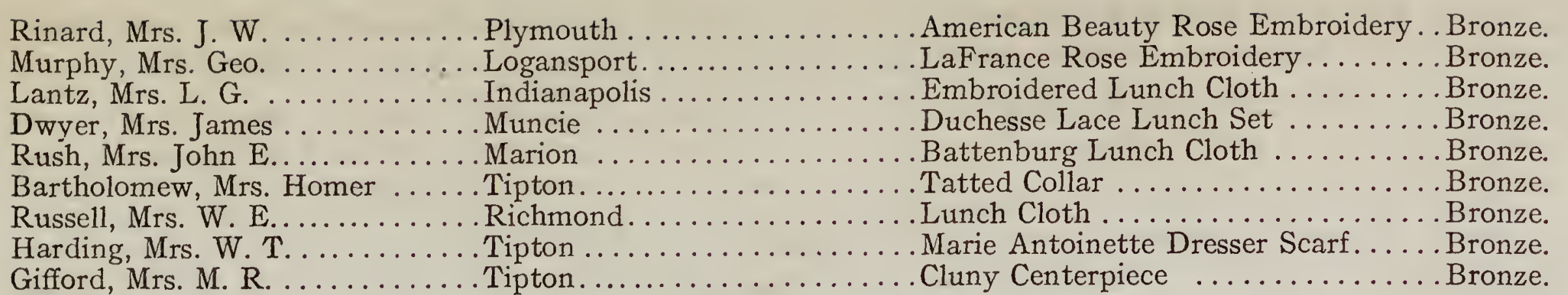

\section{AWARDS ON DECORATED CHINA} GROUP 45.

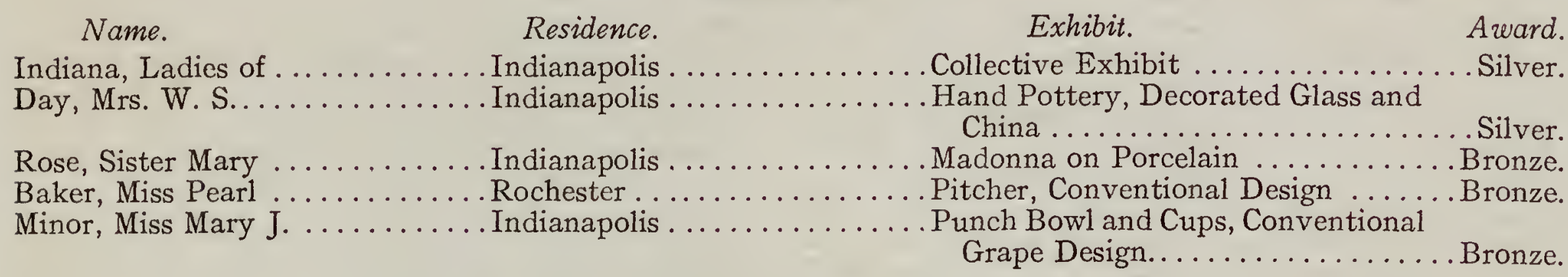

\section{Individual Exhibits}

One of the most important and gratifying reports we are pleased to make is of the excellent showing made by individuals and corporations of the state.

One hundred and eight exhibits represented the arts and trades of Indiana, and in almost every department these ranked with the best. In many instances the exhibits showed superiority in quality and mechanical skill compared with other exhibits in the same departments.

In the Livestock Department, special credit is due to the livestock breeders of the state. Records of the Exposition place Indiana first of all the states in several of the higher grades of livestock. This is both creditable and encouraging to our stock raisers. These exhibits were indicative of the rapid pace the state is making in every department of industry.

The Commission refunded the freight and express on livestock exhibits as a means of encouragement to exhibitors.

A correct list of exhibits is appended and as nearly as could be ascertained, a list of awards and prizes. It was intended to give a brief description of each individual exhibit, but it was found impossible to secure the proper data at the time of making this report.

To the Committee having in charge the agricultural and horticultural exhibits, was also assigned the duty of 
interesting Indiana livestock breeders in the Exposition, to the end that an adequate representation of this industry might be made. The Committee appointed from among the prominent breeders of the state a superintendent for each breed of stock. The gentlemen who accepted appointments in these capacities rendered valuable service to the Commission, and aided materially in making the magnificent showing of the best specimens of livestock from the herds and flocks of Indiana breeders. The names of these superintendents follow:

\section{HORSES}

Exhibit.

PERCHERONS AND SHIRES.

Name.

Address. Cochran, Lew W..................... Crawfordsville. Nave, A. P..................................... Attica.

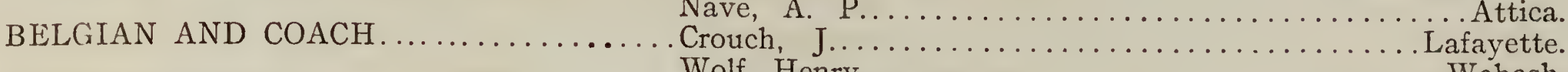

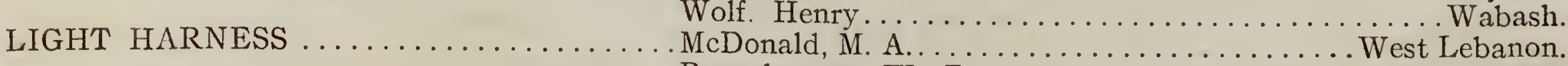
Beauchampe, W. T........................ Indianapolis. CLYDESDALES. Perd, E. H.............. New Castle. Lagrange, $J$. W............................. Franklin.

\section{CATTLE}

SHORT HORNS

Robbins, W. S........ ............... Horace. Christian, W. F................................

POLLED DURHAMS. Miller, John H......................... Peru Hines, F. S . . . . . . . . . . . . . . . . . . . . . Indianapolis. HEREFORDS . . . . . . . . . . . . . . Graves, Clem . . . . . . . . . . . . . . . . . . . . . Bunker Hill.

Van Natta, F. W................................. Kerr, Lew................................. Newtown.

Peak, W. R............................... Greensburg.

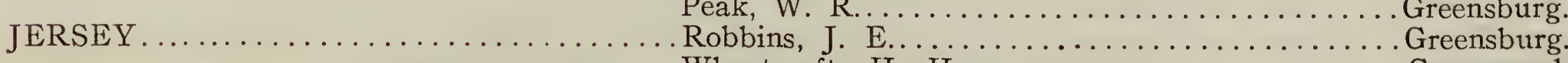
Wheatcraft, H. H.............................. Greenwood.

\section{SWINE}

Joe Cunningham, Peru, General Superintendent.

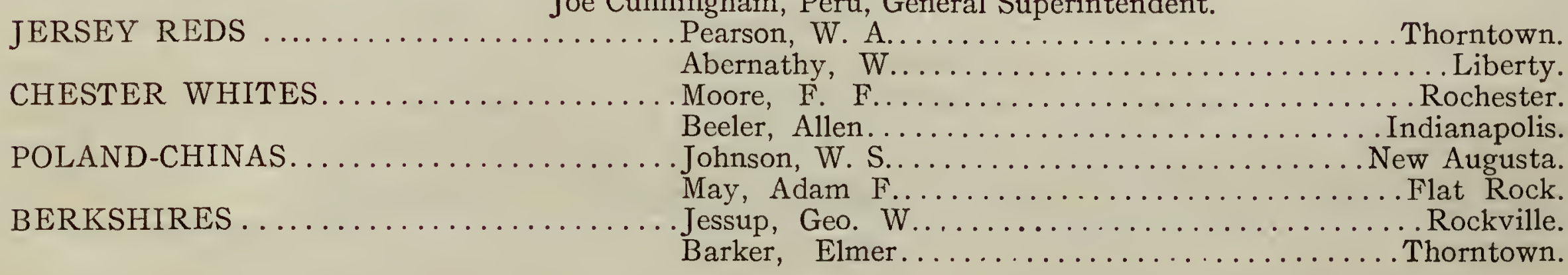

\section{SHEEP}

John L. Thompson, Gas City, General Superintendent. 


\section{POULTRY}

Sid Conger, Shelbyville, General Superintendent.

\section{Individual Exhibitors}

\section{DEPARTMENT OF LIBERAL ARTS}

\section{GROUP 16.}

Photography.

\begin{tabular}{|c|c|c|c|}
\hline $\begin{array}{l}\text { Name. } \\
\text { Koch, H. E. }\end{array}$ & Residence. & Exhibit. & $A w$ \\
\hline Parrott, J. C. & $\begin{array}{l}\text {. Laporte..... } \\
\text {. Fort Wayne }\end{array}$ & $\begin{array}{l}\text { Photographs. } \\
\text { Photographs }\end{array}$ & \\
\hline Pike, C. C. ....... & Indianapolis & Photographs & \\
\hline Wilhite \& Holloway & Indianapolis & Photographs & \\
\hline
\end{tabular}

\section{GROUP 17.}

Name.

Bobbs-Merrill

Name.

Allison, W. D., Co

Armstrong, W.

Clark \& Roberts

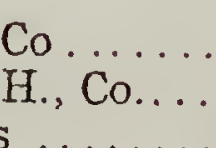

(n)

(n)

Name.

Conn, C. G.

Starr Piano Co.

\section{Books and Publications.}

Residence.

Indianapoli

\section{GROUP 20.}

Medicine and Surgery.

Residence.

Indianapolis

......... Physicians' Supplies

Indianapolis .......... Physicians' Supplies

\section{Exhibit.}

Books and Publications

Award. Silver.

GROUP 21.

\section{Musical Instruments.}

\section{Residence.}

\section{Elkhart .}

Richmond. Exhibit.
$\ldots \ldots \ldots \ldots \ldots$ Musical Instruments.

Award.

Also Gold Medal to Henry Gennett, President, as Collaborator.

\section{GROUP 23.}

Name.

\section{Chemical and Pharmaceutical Arts.} Residence.

Western Gas Construction Co.

Fort Wayne

Exhibit.

Award.

Also Grand Prize to O. N. Guldlin, as Collaborator, and Silver Medal to A Aparatus 
GROUP 26.

Models, Plans and Designs for Public Works.

Name. Address.

Exhibit.

Award.

Western Gas Association.

. New Albany.

Gas Apparatus.

High Pressure Gas Regulator. . . . . Silver.

\section{DEPARTMENT OF MANUFACTURES}

GROUP 34.

Name.

Brushes and Fine Leather Novelties.

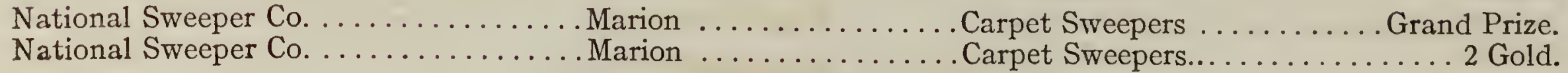

\section{GROUP 37.}

Name.

Decoration and Fixed Furniture.

Address. Exhibit.

Award.

Interior Hardwood Co.

Indianapolis

Parquetry Flooring

Gold.

GROUP 38.

Office and Household Furniture.

\section{Name.} Address.

Exhibit.

Award.

Goshen Mfg. Co.

Goshen

.Swings and Ladders

Bronze.

Study, Mrs. J. N

Fort Wayne.

\section{GROUP 41}

Name. Address. Exhibit. Award.

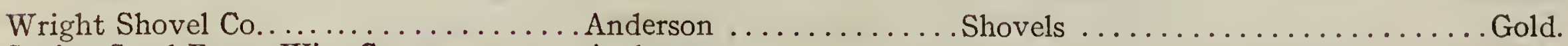

Spring Steel Fence Wire Co...........Anderson ................................ Silver.

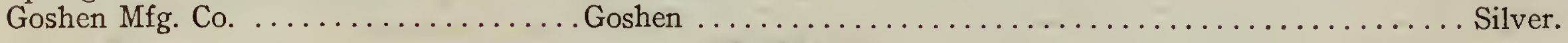

irame. GROUP 48

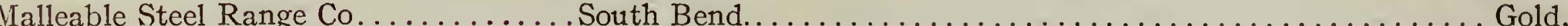

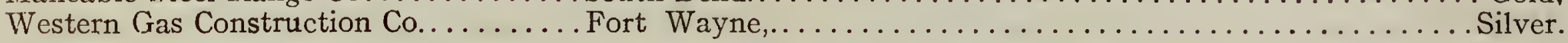

GROUP 49.

Methods for Lighting.

Name. Address. Exhibit. Award.

Davis Acetylene Co...............Elkhart....................... Gold.

Also A. Davis, President, awarded Gold Medal as Inventor.

Roots, P. H. \& F. M. .............. Connersville ............ Gas Exhaustor .................Gold.

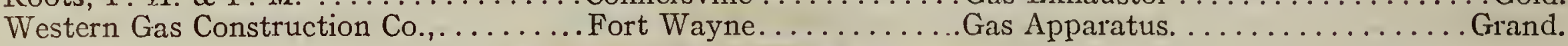
GROUP 56.

\section{Yarns and Fabrics of Animal Fibres.}

Name. Address.

Exhibit.

Award.

Seymour Woolen Factory Co.

Woolens and Flannels

Gold. 


\section{GROUP 61.}

\section{Industries Connected with Clothing.}

Name. Address.

Exhibit.

Award.

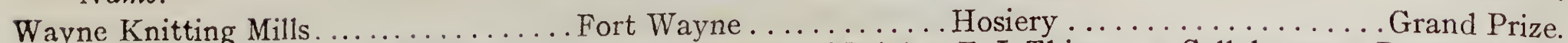
Also Gold Medal to T. F. Thieme, as Collaborator; Silver Medal to F. J. Thieme, as Collaborator; Bronze Medal to H. Stoehral, as Collaborator; and Bronze Medal to Anna Klebe, as Collaborator.

\section{DEPARTMENT OF MACHINERY}

\section{GROUP 62.}

Steam Engines.

Name. Address.

Exhibit.

Award.

Kunkle, E. B., Co.

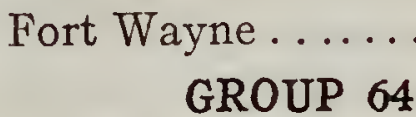

\section{General Machinery.}

Name.

\section{Address.}

Exhibit.

Award.

Dodge Mfg. Co. ................... Mishawaka ........... Power Transmission Machinery ...... Gold.

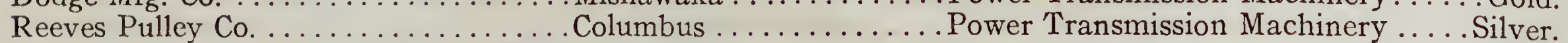
Howe Engine Co................ Indianapolis . ......... Fire Engine............... Bronze. South Bend Pulley Co. ........... South Bend .......... Pulleys................. Bronze.

\section{GROUP 63.}

Western Gas Construction Co. .........Fort Wayne ........... Iron mountings and requirements for retort benches.

Silver.

\section{GROUP 65.}

Name.

\section{Machine Tools.}

Bertsch \& Co.. Address.

Exhibit.

Award.

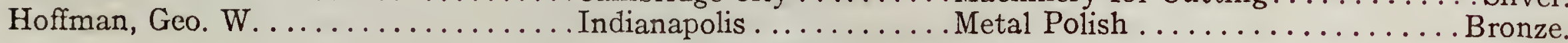
Power Plants.

Connersville Blower Co. ........... Connersville .......... Rotary Pumps.

\section{DEPARTMENT OF ELECTRICITY}

\section{GROUP 67.}

Name.

Commercial Electric Co.

Goldsboro, W. E.

\section{Machines for Generating Electricity.}

$$
\text { Address. }
$$

Exhibit.

Award.

Indianapolis

Dynamos and Motors

Electro Dynamometer 
McRoy Clay Works.

Brazil

Vitrified Clay Conduits .

Silver.

Morgan Electric Co.

East Chicago............ Third Rail Haulage System

Purdue University Electrical Research

Laboratory ...........................

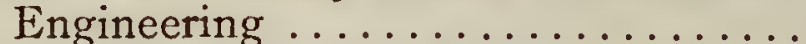

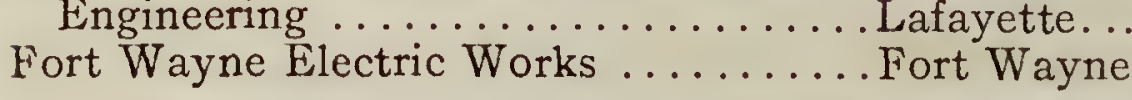

. Electrical Apparatus . .

Gold.

GROUP 69.

Electric Lighting.

Address.

Transformer

For Altcrnating Current Motors

and Transformers............. Silver.

\section{Name.}

athews, C.

Fort Wayne Electric Works.

Lafayette.

Exhibit.

Award.

Fort Wayne

Photometers.

. Gold.

\section{GROUP 71.}

Various Applications of Electricity.

Address.

Direct and Aiternating Arc Lamps

and Arcilighting System........ Gold.

\section{Name.}

Exhibit.

Award.

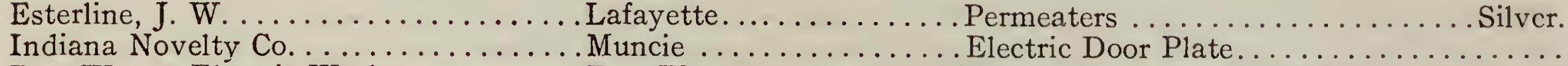

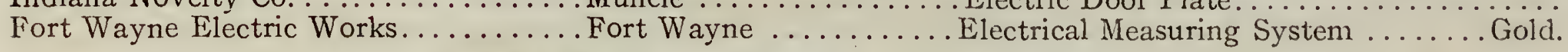

\section{DEPARTMENT OF TRANSPORTATION \\ GROUP 72.}

Name.

\section{Carriages and Wheelwrights' Work-Automobiles and Cycles.}

Elkhart Carriage Co. ............. Elkhart . . . . . . . . . Carriages ................ Silvcr.

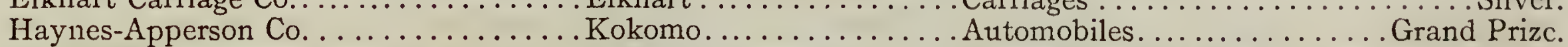

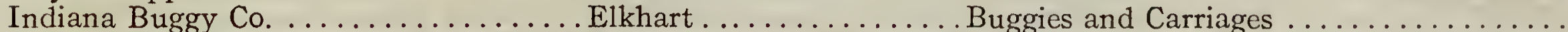

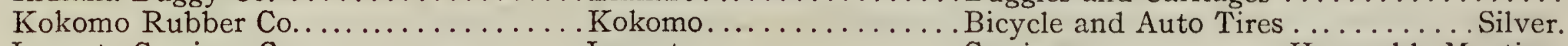

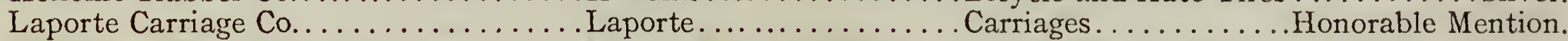

McCallum Wagon Co. ...............Plymouth ............Wagon Wheels ...............Bronzc.

Motsinger Device Co. ............. Pendleton .............. Auto Sparker.............. Bronzc.

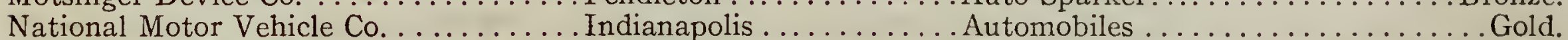

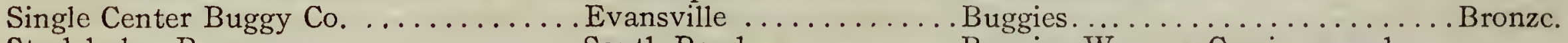

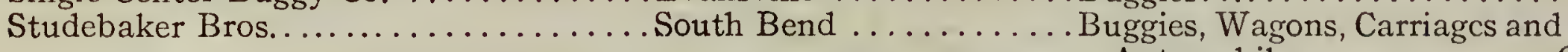

\section{GROUP 73.}

Automobiles ............. Grand Prize.

\section{Harness.}

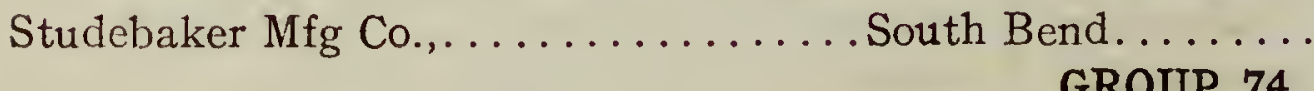

Railway Facilities.

Name.

Address.

Harness.

Grand Prize.

agerstown

Exhibit.

Award.

Light Inspection Car Co. .Inspection Cars

Gold. 


\section{DEPARTMENT OF AGRICULTURE}

GROUP 78.

Farm Equipment.

Name. Address.

Exhibit.

Award.

Slack, W. J

Bloomington

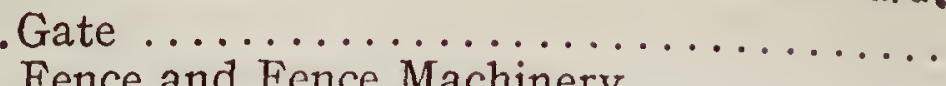

Weisenbaum Mfg. Co

Indianapolis .

\section{GROUP 79.}

\section{Agricultural Implements and Farm Machinery.}

\section{Name.} Address. Exhibit.

Award.

South Bend Chilled Plow Co. ........ South Bend .......... Plows . . . . . . . . . . . . . Silver. Blount, H. F . ................ Evansville . . . . . . . . Plows . . . . . . . . . . . . . . . Silver. Bowsher, N. P., Co. .............. South Bend ..........Feed Grinding Mills............. Gold. Fowler Stufflebean Mfg. Co. .........Judyville............. Corn Shredder ............... Silver. Gaar, Scott \& Co. ................Richmond........... Threshing Machinery ........... Gold

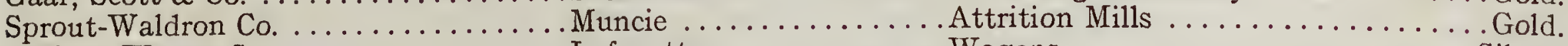

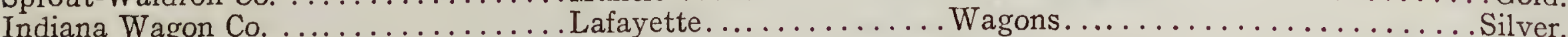
Oliver Chilled Plow Co. ........... South Bend ........... Plows ............... Grand Prize.

Also Jas. Oliver, Gold Medal, as Inventor.

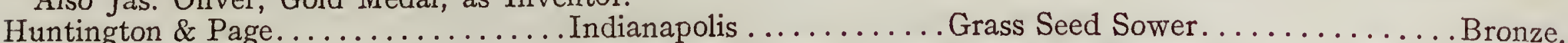
Birdsell Mfg. Co................. South Bend ........... Clover Huller................. Gold

\section{GROUP 86.}

\section{Equipment and Methods Employed in Preparation of Foods.}

Name.

Wilke Mfg. Co. .

Opal Refgr. Co.

Name.

Iglehart Bros

Name.

Haffner, Mrs. B

\section{Address.} Anderson .... Exhibit.

Award, Refrigerators Refrigerators

\section{GROUP 87.}

\section{Farinaceous Products.}

\section{Address.}

Evansville

\section{GROUP 88.}

Address.

Anderson

\section{GROUP 89.}

\section{Food Products.}

Whitney, I. J., \& Son

Cambridge City

Polk, J. T.

Greenfield

Lebanon
Award. Grand Prize.

$$
\text { Exhibit }
$$

Award. Exhibit. . Gold. Cakes 


\section{GROUP 94.}

Fermented Beverages.

Name. Address.

Indianapolis Brewing Co.

Indianapolis

Exhibit.

Award.

\section{FINE ARTS DEPARTMENT}

\section{GROUP 9.}

Name.

Adams, J. Ottis

Address.

Ball, Clarence I

Bundy, J. E.

Indianapolis .

South Bend

Richmond.

Fountain City

Connor, Chas.

Forsyth, Wm.

Gruelle, R. B ndianapolis

Indianapolis

Steele, T. C................ Indianapolis . .

Indianapolis

Exhibit.

The Wane of Winter, Iridescence of a Shallow

Strcam, and The Ebb of Day............. Bronze.

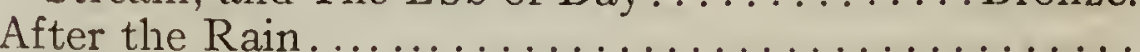

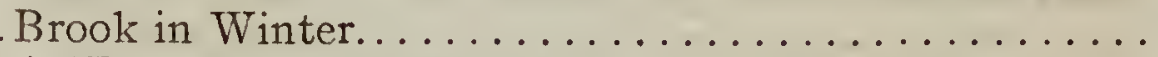

A Wet Night In February.

ate Afternoon, Morning on the River, Cloud

Shadowed Hill............... Silver and Bronze. Golden Glow of a Summer Afternoon. ............... .Low Tide, Oregon Coast, The Old Mills,

November Morning, The Old Sycamores..........

Starke, Otto
The B

\section{GROUP 108.}

\section{Ornamental Trees, Shrubs, etc.}

Name. Address.

Exhibit.

Award.

Hill, The E. G. Company............ Richmond............ Chrysanthemums and Roses ....... Gold.

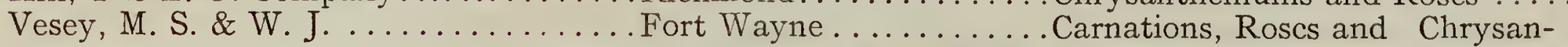

Coles, W. W.

Kokomo. themums ................... Gold.

Bertermann Brothers Co............ Indianapolis ........... Cyclamen Plants ............. Silver.

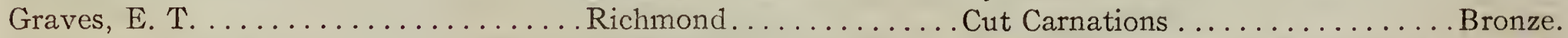
Floral, B. K. \& B. Co. ............. Richmond............ Chrysanthemums and Carnations ... Bronze.

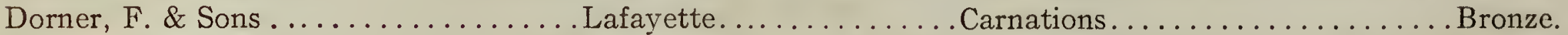
Teilmann, Gunnar ................ Marion ............. Chrysanthcmums ............. Bronze.

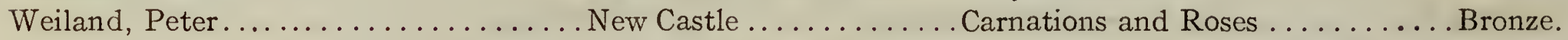

DEPARTMENT OF FORESTRY

\section{GROUP 112.}

Name. Address.

Exhibit.

Award.

International Society of Arboriculture 


\section{DEPARTMENT OF MINES AND METALLURGY}

GROUP 115.

Name. Address.

Morgan Electric Machine Co. . East Chicago.

Crawford \& McCrimmon Co.

Brazil Third Rail Electric Min. Locomotive System. . . . . . . . . . . . . Gold.

Crawford, C. W. entilating Fan, Hoisting Engine, Mine Pump............ Silver.

Brazil GROUP 116.

Name. Address.

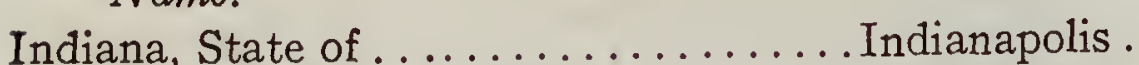

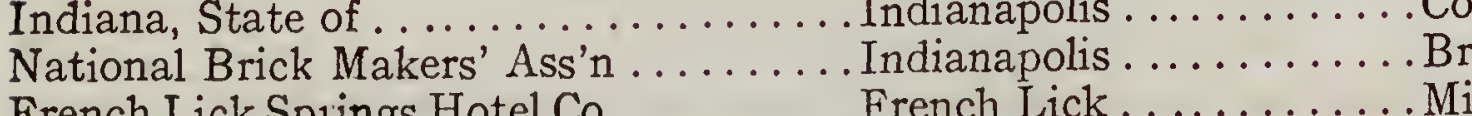
entilating Fan for Mines ......... Silver.

Exhibit.

Award.

rench Lick Springs Hotel Co. . . . . . . . . . . .

West Baden Sprdngs Co................

Martinsville Sanitarium Co..............

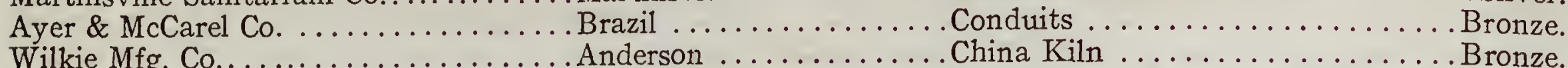

Mineral Water

West Baden ............ Mineral Water ............... Silver.

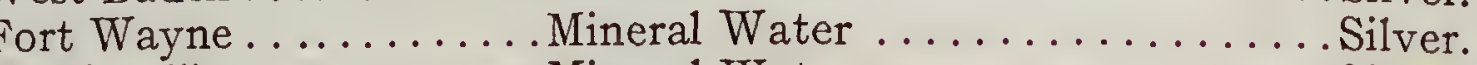

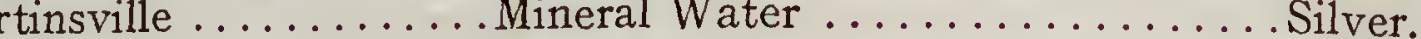

Western Gas Construction Co. ......... Fort Wayne............ Methods and Apparatus for Cooling and Condensing Coal Gas.

Recovering of By-Products........ Gold.

GROUP 118.

Name. Address.

Exhibit.

Award.

Western Gas Construction Co.

Fort Wayne.

\section{Gas Generating Apparatus, Charg-}

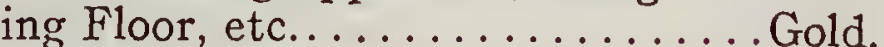

Roots, P. H. \& F. M., Co.............Connersville ........... Foundry Blower. .............. Gold.

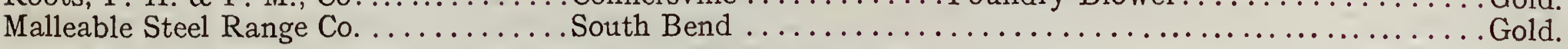

GROUP 119.

Name.

Literature of Mining. Address.

Exhibit.

Award.

Indiana Geological Survey ........... Indianapolis . ........ Reports . . . . . . . . . . . . . . Gold.

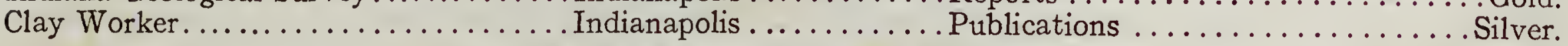

\section{DEPARTMENT OF FISH AND GAME}

\section{GROUP 120 .}

Name.

Hunting Equipment.

Sloan, J. W Address.

Exhibit.

Award. Temple. GROUP 122.

Fishing Equipment and Products.

Name. Address.

Exhibit.

Award.

Eigemann, C. H

Bloomington

Books on Fishes

Gold. 
In the Departments of Social Economy and Physical Culture, the following Indiana institutions were represented:

GROUP 138.

Name.

School of Social Sciences of Catholic

General Betterment Movement.

Address.

Exhibit.

Award.

University of Americ

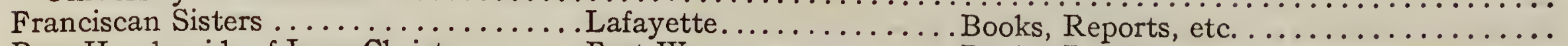

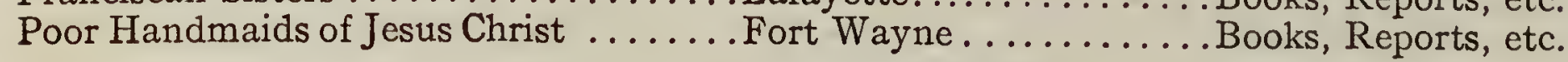

\section{GROUP 139.}

\section{Charities and Corrections.}

Name.

Address.

Exhibit.

Award.

National Children's Home Society.

Indiana Children's Home Society

Indianapolis

Books, Charts, etc

GROUP 142.

Physical Training.

Name. Address.

Exhibit.

Award.

\section{Earlham College}

Richmond

Pennant

Franklin .................. Pennant

University of Indiana $\ldots \ldots \ldots \ldots \ldots \ldots$. Bloomington $\ldots \ldots \ldots \ldots$ Pennant

Culver Military Academy

Culver.

Charts, etc.

North American Gymnast Union ........ Indianapolis .

\section{Live Stock Department}

\section{HORSES}

Exhibitor.
hran, Ethelyne, \& L. W.

\section{Location.}

Awards.

Entries

Cochran, Ethelyne, \& L. W.......... Crawfordsville.

20 First

7 Gold Medals.

7 Diplomas.

3 Premier Championships.

4 Reserve Championships.

1 Reserve Grand Championship.

1 Championship.

Henderson \& Rice

Crawfordsville

\section{Third.} 2

Crouch, J. \& Son

Lafayette.

Crouch, G. R.

Lafayette. 


\section{SHEEP}

Exhibitor.

Roundtree, Chas.

Crawfordsville

1 First....

Webb, John E.

Southport

4 First. .

2 Fourth.

Gardner \& Collins

Roachdale

7 . First. .

4 Third.

3 Fourth.

5 Fifth.

5 Sixth

4 Seventh.

2 Championships.

Hartman, F. P................. Fincastle

11 First.

2 Second

5 Third.

2 Fourth.

2 Fifth.

3 Sixth.

1 Seventh.

Keim, H. H

.Ladoga.

1 Championship.

1 Premier Championship.

1 Grand Championship.

Silver Cup in Sheep Shearing Contest.

\section{Exhibitor.}

CATTLE

Bower, E. W.

Location.

Awards.

Entries.

.Delphi

1 First. .

3 Fourth.

1 Sixth.

1 Seventh.

1 Senior Championship.

1 Grand Championship.

Robins, J. G. \& Sons

Horace

6 First. ....

3 Third.

1 Sixth.

1 Championship. 
VanNatta, W. S. \& Son ........... Fowler.

2 First

2 Third.

1 Fourth.

3 Sixth.

2 Seventh.

2 Senior Championships.

2 Grand Championships.

Brookside Farm Co. ............. Fort Wayne

5 First.

5 Second.

1 Third.

1 Fourth.

3 Fifth.

1 Sixth.

1 Junior Championship.

1 Reserve Championship.

1 Reserve Junior Championship.

2 Premier Championships.

Hadley, Oscar ................Plainfield

2 First.

1 Second.

1 Third.

3 Fourth.

3 Fifth.

2 Commendations.

Hartner \& Gurtner............... North Manchester.

1 Third.

3 Fourth.

1 Fifth.

Hines, F. S. ................Malott Park.

9 First.

4 Second.

3 Third.

3 Fourth.

Miller, H. C., \& J. H.............. Peru

5 First.

2 Second.

3 Third.

3 Fourth.

2 Fifth.

1 Championship.

1 Premier Championship.

Wood, A. C., \& Sons

Pendleton

5 Second.

3 Third.

1 Fifth.

2 Championships.

3 Reserve Championships.

1 Grand Championship.

1 Premier Championship. 
Robbins, J. E

Greensburg.

6 First

2 Second.

1 Fourth.

2 Fifth.

2 Sixth.

2 Seventh.

1 Reserve Championship.

1 Premier Championship.

\section{SWINE}

Exhibitor.

Location.

Awards.

Entries.

Graham, M. B................ Remington

1 Second

Remington

1 Second.

Washburn, James .

Remington

1 First.

2 Fourth

1 Fifth.

2 Sixth.

1 Reserve Championship.

Shuster, H. M.

Remington

1 Seventh.

Jessup, G. W.

Rockville

1 First. .

1 Second.

2 Third.

1 Sixth.

1 Junior Championship.

1 Reserve Championship.

Etzler \& Moses

Decatur

1 Third.

3 Fourth.

1 Sixth.

1 Seventh.

Barker, I. N. \& Son

Thorntown

1 Third.

2 Fourth

4 Fifth.

Riley, J. \& Son

Thorntown

2 First. .

4 Second.

4 Third.

2 Fourth.

Teeter, J. A. ..................Remington

1 First. .

3 Second.

1 Fifth.

May, C. W

Remington

1 Junior Championship.

1 Fourth

1 Seventh.

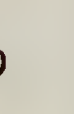

$\ldots \ldots \ldots \ldots \ldots \ldots$

$\ldots \ldots \ldots \ldots \ldots \ldots 23$

$\ldots \ldots \ldots \ldots \ldots . \ldots$

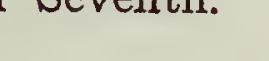


Catherwood, A. P.

Lafayette

1 First. ...................22

1 Third.

Milner, W. W. \& Sons

Thorntown

5 Complimentary.

1 First. .

2 Second.

3 Third.

1 Fourth.

1 Sixth.

1 Championship.

Rockhill, W. E.

.Aetna Green.

1 First.

5 Fifth.

1 Sixth.

1 Championship.

1 Grand Championship.

Riggs Bros.

Shirley

Arbuckle \& Sidner............... Hope .

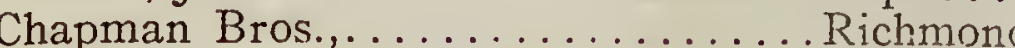
Exhibitor.
Location.
Award.
Entries.

Chappell, J. H............. Oakland City .......... 2 First $\ldots \ldots \ldots \ldots \ldots$

\section{POULTRY}

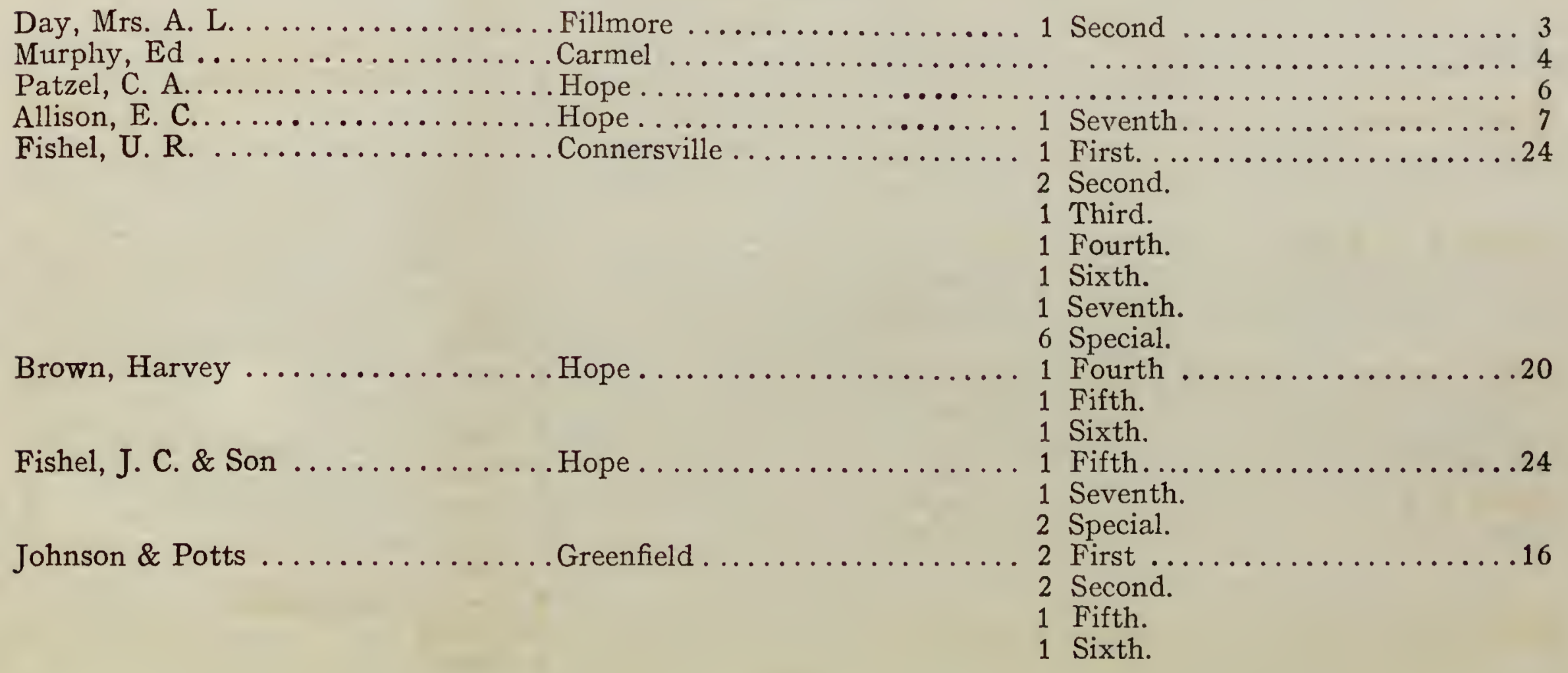


Kistler, C. W.

Indianapolis

Tobin, Wm.

Indianapolis

2 Sixth.

$\ldots \ldots \ldots \ldots \ldots$

Lanius, Wesley

. Greensburg

2

2 Third. $\ldots \ldots \ldots \ldots \ldots \ldots \ldots \ldots \ldots \ldots \ldots \ldots \ldots$

1 Fourth.

1 Sixth.

1 Seventh.

Ulrey, B. F.

Shadeland. 12

Clark. Dr. H. P.

. Indianapolis .

8 First.

2 Second.

1 Third.

Carver \& Avey

Columbia City

2 Fifth.

Smiley, T. N. \& Son

Milligan .

2 First

Roots, D. T. .................. Connersville

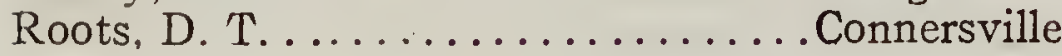

1 Second.

2 First ................ 7

1 Third..................... 56

1 Fourth.

1 Sixth.

1 Ninth.

Lane, S. B.

Spiceland

1 First.

2 Fifth.

Johnson, F. P.

Indianapolis

1 Sixth.

2 Second...................12

1 Fourth.

2 Sixth.

1 Seventh.

Rominger, Walter .............. Indianapolis
Fordice, Mrs. Morton $\mathrm{W} . \ldots \ldots \ldots$ Russellville. Russellville.

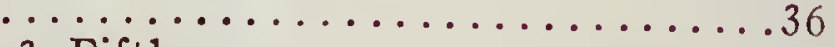

3 Fifth......................

4 Sixth.

4 Seventh.

Johnson, S. B................... Fairland

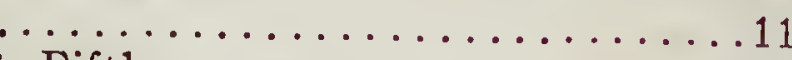

Bradshaw, Harmond.............. Lebanon ...

1 Fifth.........................

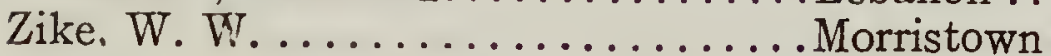

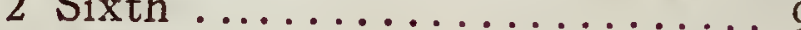

Weiss, F. C.

Evansville

1 Second.

10 First. ..................23

7 Second.

2 Third.

2 Fourth.

1 Fifth. 


\section{Summary of Disbursements}

The follorving is a summary of the moneys expended in the different departments that have been made by the Commission to this date:

General Expenses of the Commissioners.

Express, freight and drayage ...

46.52

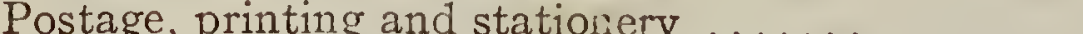

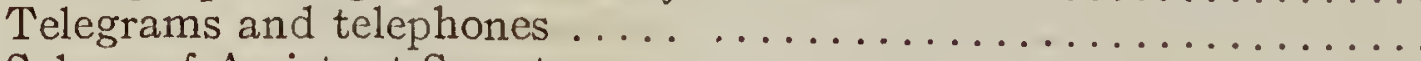

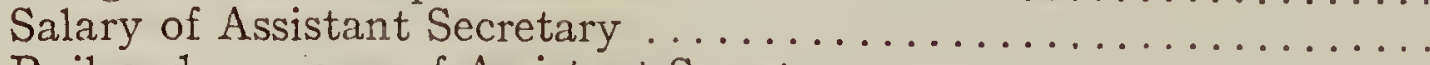

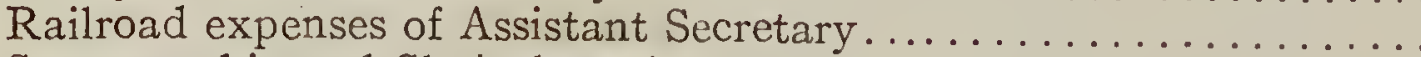

Stenographic and Clerical service.

Supplies

Publicity and Promotion:

Postage

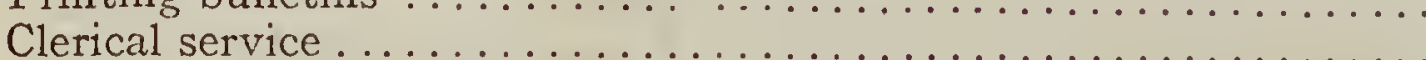

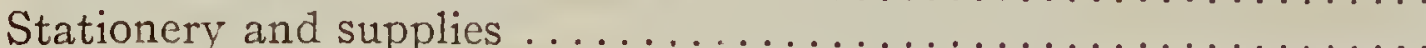

State Building:

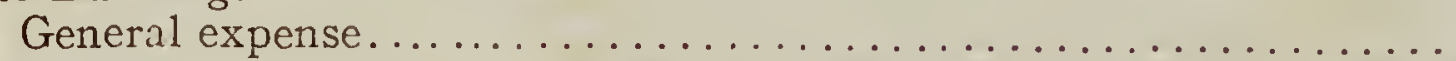

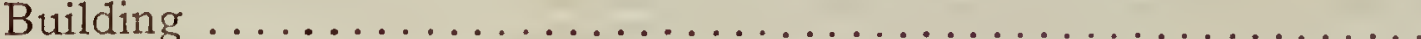

Furnishings.

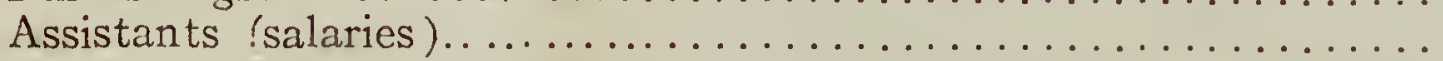

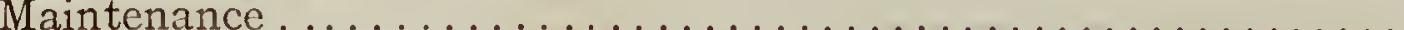

Committee on Manufactures:

Postage

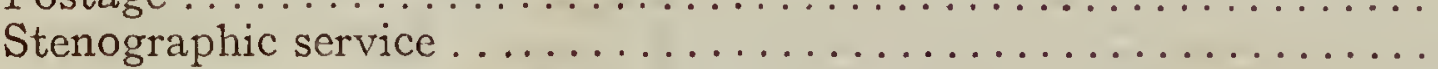

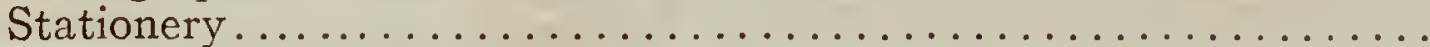

Committee on Transportation:

Postage

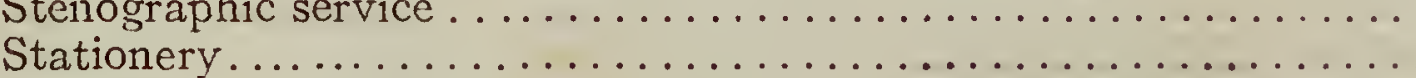

Express.

AGRICULTURE

Installation:

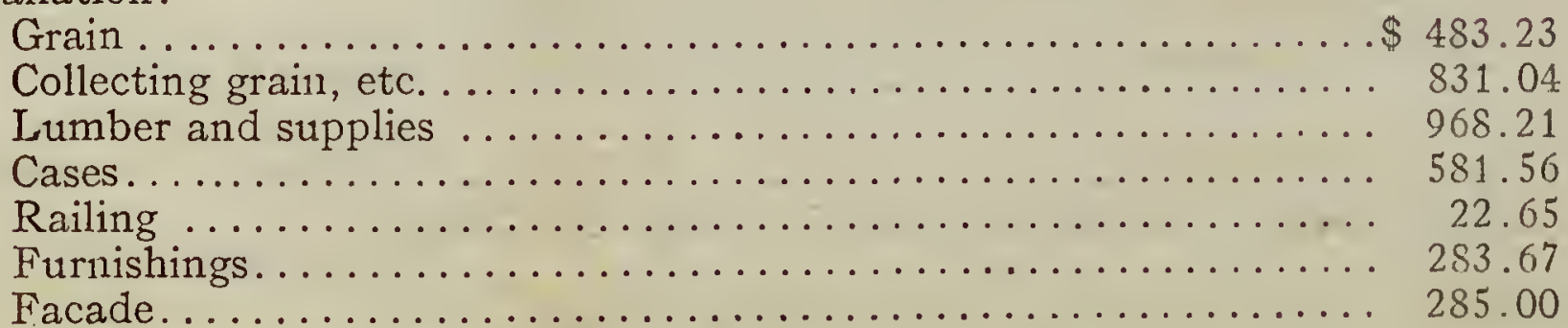

Facade. 
Statues

Salary, Superintendent and Attendants

Installation:

HORTICULTURE.

Fruit

Tables and furnishings

Maintenance:

..... 590.00

Monograph

\section{LIVE STOCK.}

Dairy Exhibit:

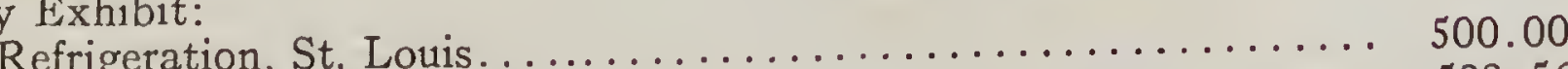

Expense, superintendence...................... 588.56

loitation:

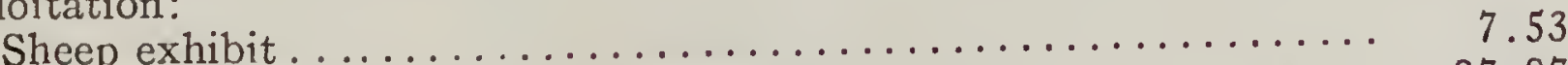

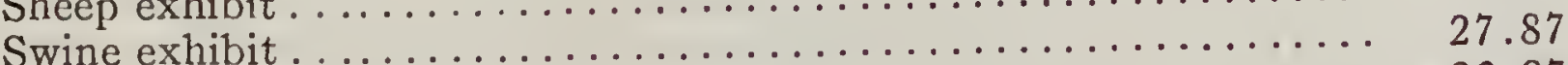

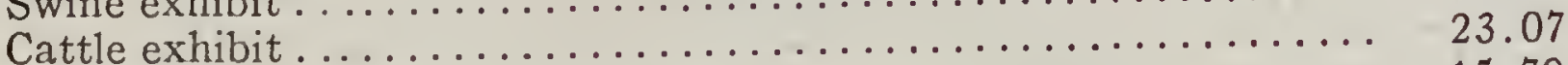

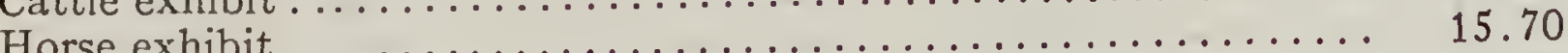

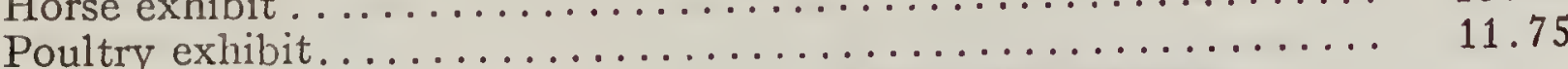

Installation:

\section{BUILDING STONE.}

Plans . .

126.38

Construction

2527.00

Furnishings.

Maintenance:

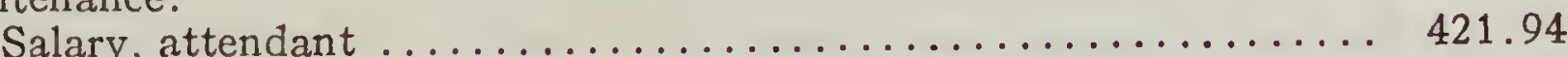

Janitor service

\section{COAL EXHIBIT.}

Installation:

Freight, drayage, etc., on coal .................... 503.21

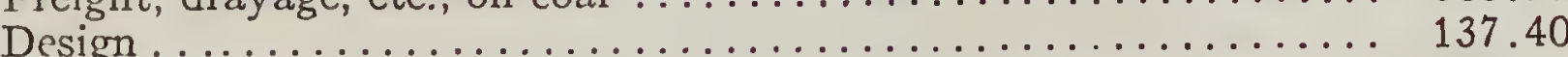

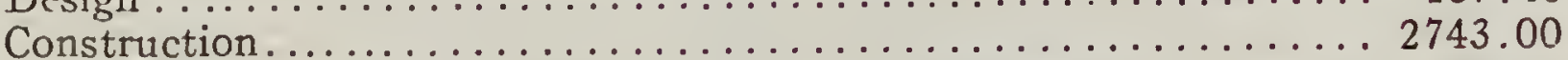

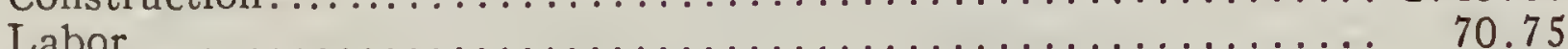

Maintenance:

Salary of attendant.

270.00 270.00

Installation:

EDUCATIONAL EXHIBIT: SCHOOLS AND COLLEGES.

Expense collecting exhibit, etc. 
Booths

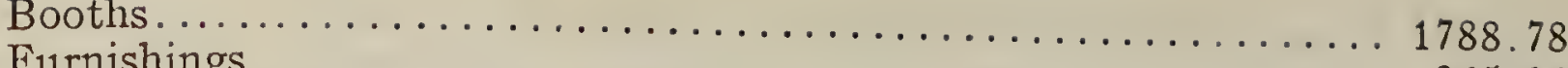

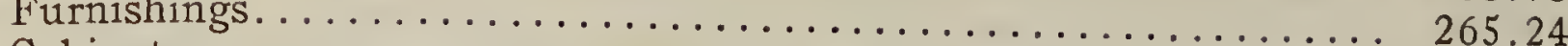

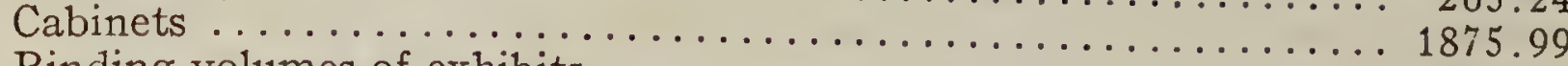

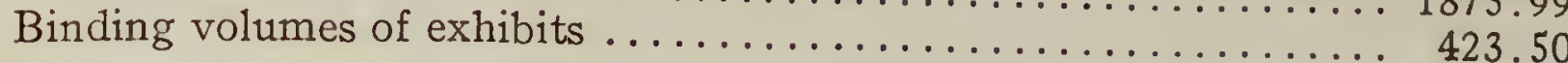

5704.93

Maintenance:

Salaries, Superintendent and Attendants .............. 1741.54

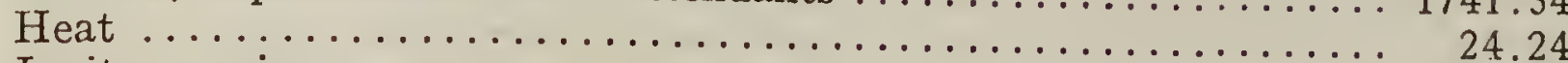

Janitor service ............................. 139.50

$1905.28 \quad 7610.21$

Library exhibit

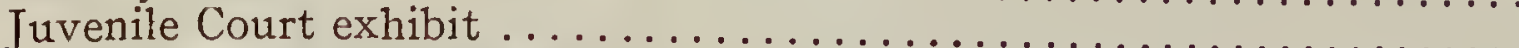

State Board Charities exhibit.

Department of Hygiene.

School for Feeble-Minded You

Printing "History Education"

WOMAN'S WORK.

Installation:

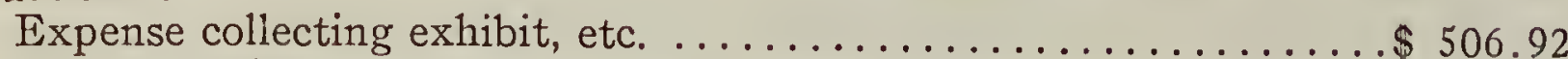

Booths, design ................................ 35.00

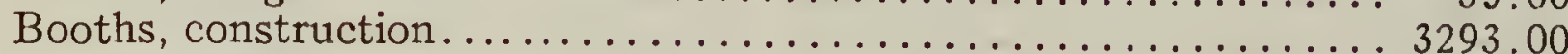

Furnishings............................... 126.28

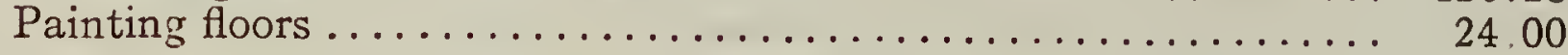

3985.20

Maintenance:

Insurance ............................... 221.30

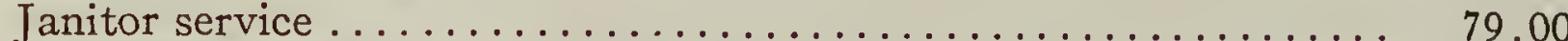

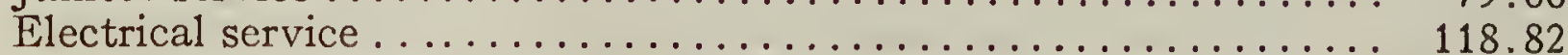

Salary, Superintendent and Attendants .................. 1413.53

1832.65

5817.85

Installation:

LITERATURE.

Expense collecting books, etc. ........................... 206.48

206.48

Maintenance:

Salary of Superintendent.

262.50

262.50

Expense, souvenir hooks

349.73

349.73

818.71

Installation:

Collecting and framing paintings

945.10

945.10

Maintenance:

Salary of Superintendent . . . . . . . . . . . . . . . . . 262.50

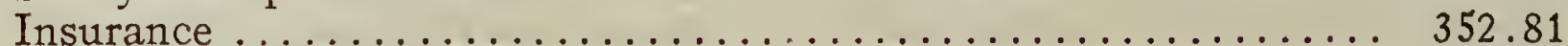

Expense, souvenir books ................................ 349.73

615.31

349.73

1910.14

Total 
There are bills filed but not paid, including freight on livestock, and items to be charged to the different departments, amounting to about $\$ 5,000$.

The sale of property of the state is as follows:

\section{SALE OF PROPERTY}

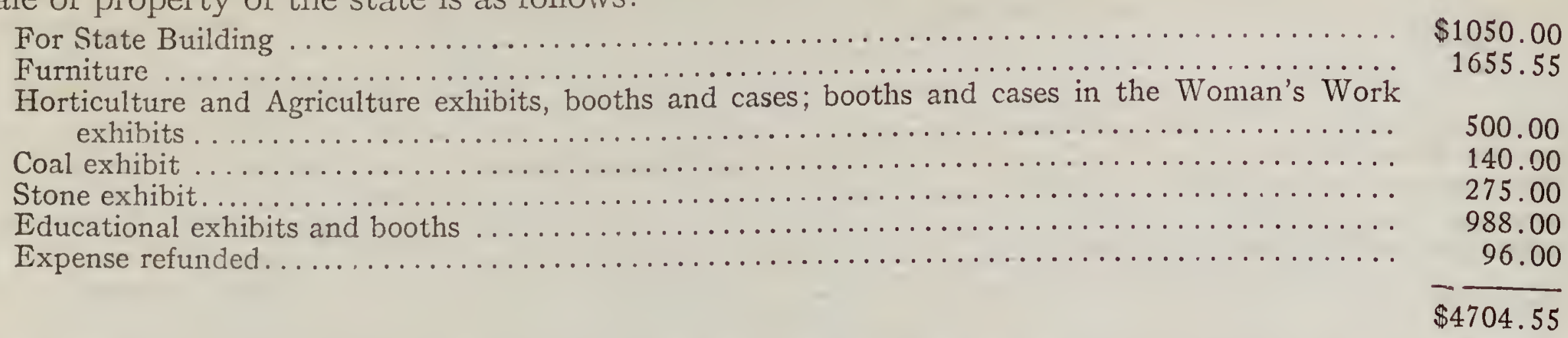

We have, with as much detail as has seemed proper, reported upon the work of the Commission as completed to this time. It is not entirely complete for the reason that there are some minor matters connected with the closing up of the business of the Exposition that cannot yet be concluded. However, this substantially covers not only what the Commission has done, but all it will need to do. The Commission desires to express to Your Excellency its full appreciation of the honor that has been conferred upon the individual members by their appointment to perform these important duties. The work has necessarily entailed a considerable personal sacrifice upon each member of the Commission, but this we have gladiy made, as we feel sure the part Indiana has taken in this great Exposition will redound to the future good and glory of our beloved state. To you we express our gratitude for the kindly interest you have manifested in our work and the intelligent assistance you have given us from time to time.

Respectfully submitted,

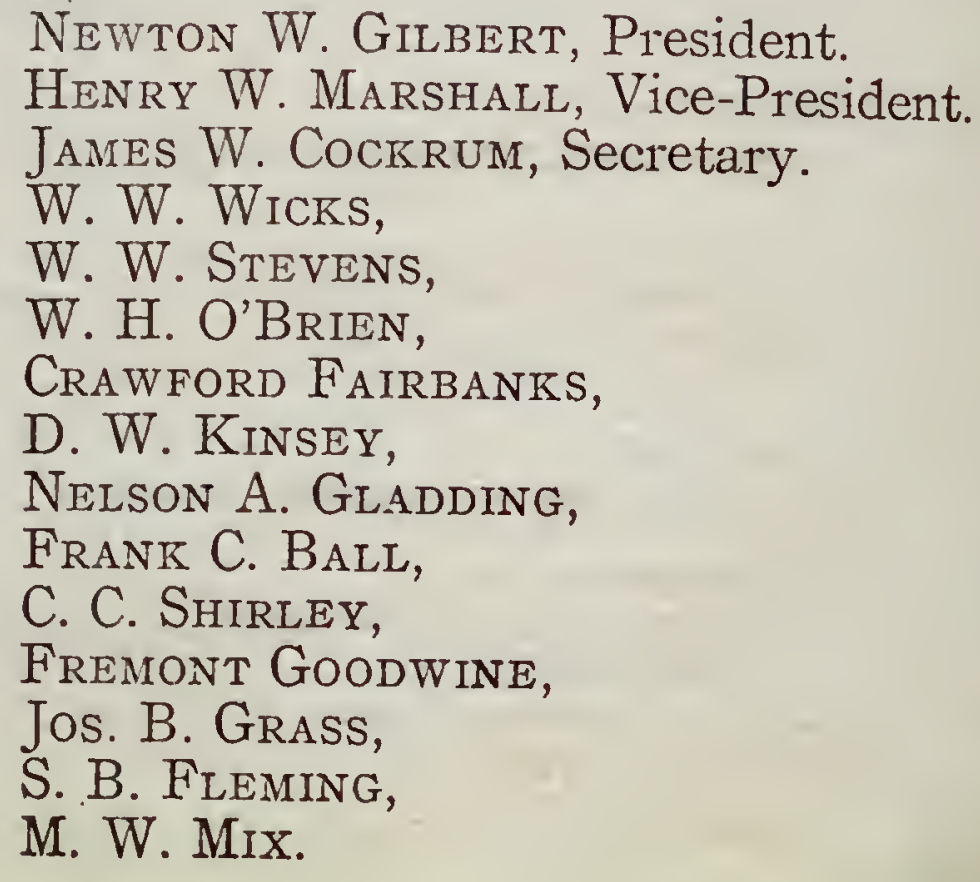




\section{REPORT OF THE LOUISIANA PURCHASE EXPOSITION COMMISSION OF INDIANA}

Received by the Governor, examined and referred to the Auditor of State for verification of the financial statement.

May 31, 1905.

The within report, so far as the same relates to moneys drawn from the State found correct.

D. E. SHERRICK, Auditor of State.

May 31, 1905

Returned by the Auditor of State, with above certificate, and transmitted to Secretary of State for publication, upon the orderof the Board of Commissioners of Public Printing and Binding.

Filed in the office of the Secretary of State of the State of Indiana, June 1, 1905

Received the within report and delivered to the printer June 1,1905.

FRED L. GEMMER, Secretary to the Governor.

DANIEL, E. STORMS, Secretary of State.

HARRY SLOUGH, Clerk Printing Bureau.

\section{OFFICE OF THE LOUISIANA PURCHASE EXPOSITION COMIMISSION OF INDIANA}

HON. J. FRANK HANLY, Governor of Indiana.

Marion, Indiana, May 31, 1905

Sir-The Louisiana Purchase Exposition Commission of Indiana having concluded its work, has the honor to submit to you its final report of moneys expended since the approval of its partial report by your predecessor, Governor Winfield T. Durbin, on January 6 , 1905.

As stated in the report of Governor Durbin there were bills filed in the office of the Commission for services previously rendered and expenses incurred, amounting to approximately $\$ 5,000.00$. Vouchers have been issued for these bills, together with the running expcnses of the Commission since that date, and are on file in the office of the Auditor of State. The following is a summary of all such expenditures:

Office Expenses:

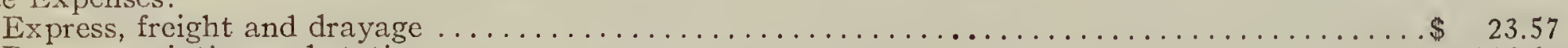

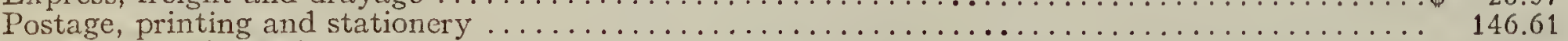

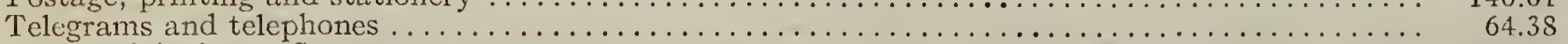

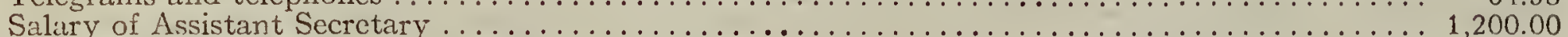

Railroad expenses of Assistant Secretary . . . . . . . . . . . . . . . . . . . . . . . . . . . . . . . . . . . . . . . . . . . .

Rtenoallo

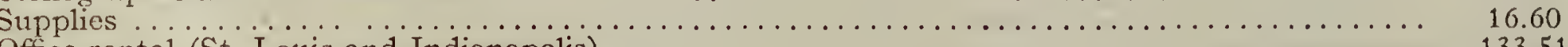

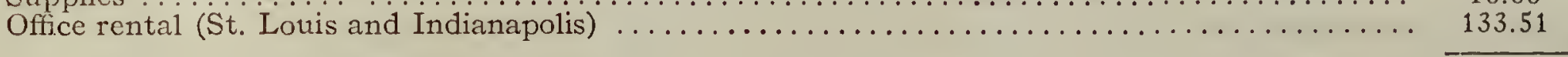

\section{PUBLICITY AND PROMOTION}

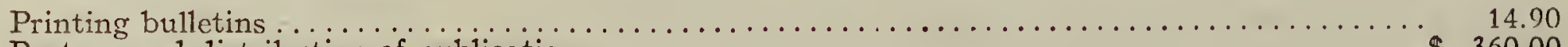

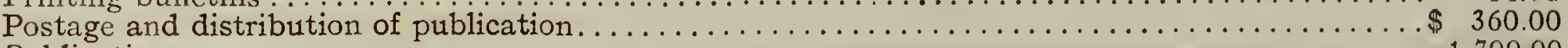

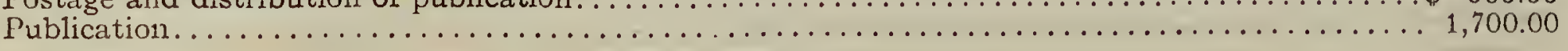

STATE BUILDING

$2,064.90$

Building 


\section{AGRICULTURE}

Installation:

Furnishings

\section{HORTICULTURE}

Installation:

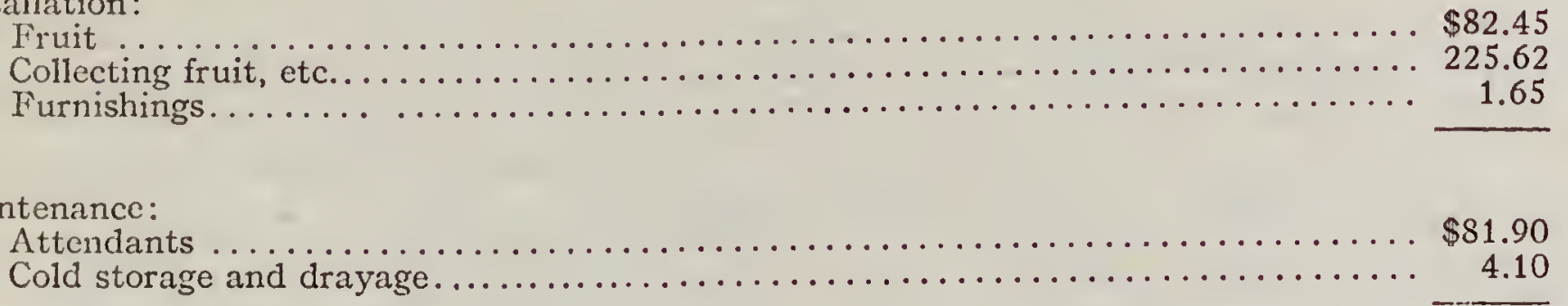

\section{LIVESTOCK}

Freight on Exhibits

Sheep exhibit

Cattle

Horse

Poultry " "

Dog

$$
\text { ", }
$$

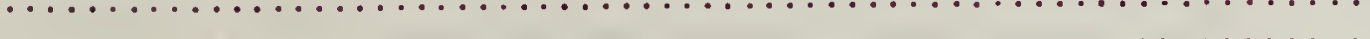

…



EDUCATIONAL EXHIBIT-Schools and Colleges

Installation:

Expense collecting exhibit

Maintenance:

Salary of attendants

$\$ 22.00$

193.65

563.29

930.15

383.40

271.04
4.07

WOMAN'S WORK DEPARTMENT

182.79

Installation:

Expense collecting exhibit

Maintenance:

Electrical service. . .

Salary of attendants. 


\section{LITERATURE}

\section{Installation}

Expense collecting books, ete.

$\$ 26.07$

\section{FINE ARTS}

Installation:

Expense eolleeting books.

$\$ 125.90$

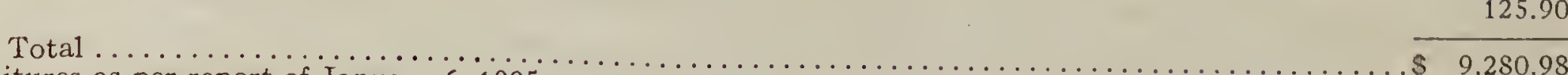

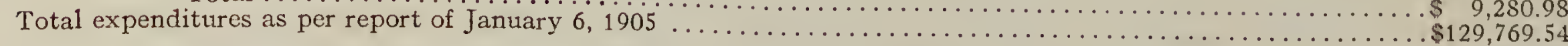

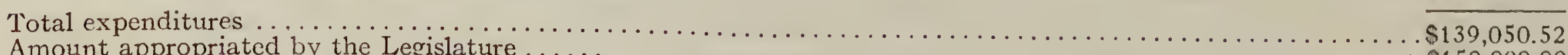

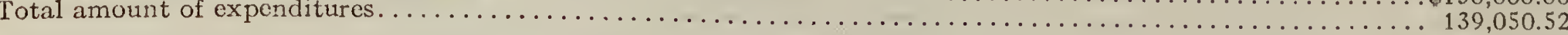

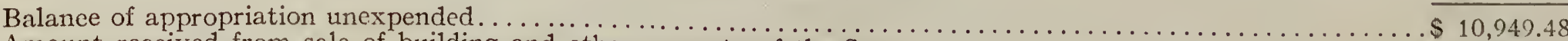

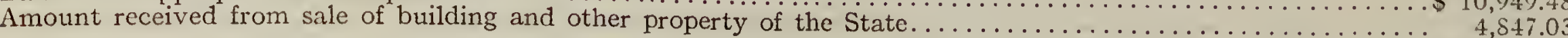

Total

We thank you most sincerely for the interest you have manifested in the work of the Commission, and desire to express to you our wishes for your future success and happiness.

The Commission adjourned sine die May 20, 1905.

Attest: JAMES W. COCKRUM, Secretary.

Respectfully submitted,

NEWTON W. GILBERT, President

HENRY W. MARSHALL, Vice-President.

JAMES W. COCKRUM, Secretary.

W. W. WICKS,

W. W. STEVENS

W. H. O'BRIEN

CRAWFORD FAIRBANKS

D. W. KINSEY

NELSON A. GLADDING,

FRANK C. BALL

C. C. SHIRLEY

FREMONT GOODWINE,

JOS. B. GRASS,

S. B. FLEMING,

M. W. MIX. 


\section{Addenda}

\section{EMPLOYEES}

The employees of the Commission, including ail those in charge of the state building and the state's exhibits, were ever loyal to the interests of Indiana, Much depended upon them in accomplishing successful results. The members of this corps of workers were active and at all times ready to carry out the plans and instructions of the Commission. They were stinutated by state pride and a desire to add to the advancement of the undertaking and to the comfort of those visiting the fair.

Below we give a complete list of persons employed by the Commission during the Exposition.

\section{INDIANA BUILDING}

Name.

McNeil, Miss Hallie

Haffiner, J. E. .

Dunn, Mrs. May Warthin

Pritchett, Miss Dale.

*Williams, Miss Hazel

Herff, Harry.

*Draper, D. E.

*McCarty, Robert

* Canaday, Ward

*Billman, Mrs. Louise

* Johnson, Theo. P.

*Held, John .

*Saint, Arthur

*Huber, A. C.

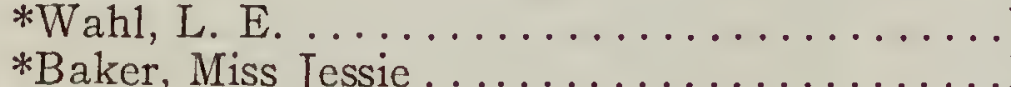

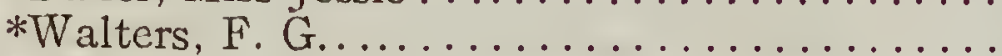

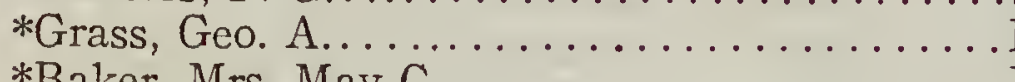

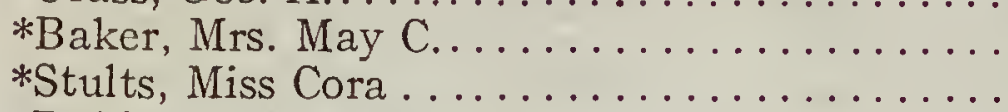

*Robinson, Miss Hazel

Lyon, Mrs. Lena...

Gosney, Miss Mary

*Beerbower, F. E.

*Avery, O. J.

*Beeks, W. L.

*Howe, J. B.

*O'Hara, J. E.
Residence.

Peru

Anderson. .

Indianapolis................ Supt. Art and Literary Dept.

Oakland City . . . . . . . . . . . . . Postmistress.

Marion ...................... Assistant Postmistress.

Peru . . . . . . . . . . . . . . . Registry Clerk

Independence $\ldots \ldots \ldots \ldots \ldots \ldots \ldots$ Registry Clerk.

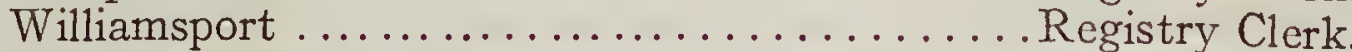

New Castle $\ldots \ldots \ldots \ldots \ldots \ldots \ldots$ Registry Clerk.

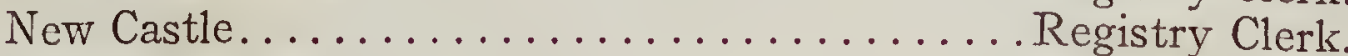

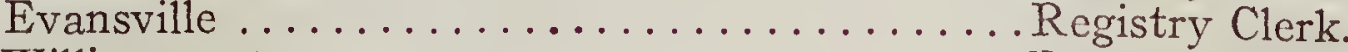

Williamsport . . . . . . . . . . . . Registry Clerk.

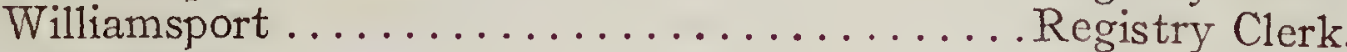

New Castle...................... Registry Clerk.

Terre Haute .................... Checkroom Clerk.

East Chicago ...................... Checkroom Clerk

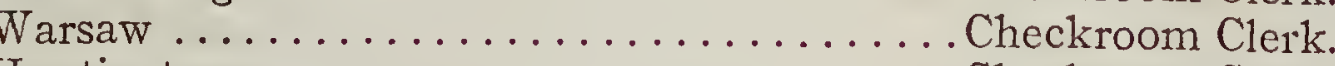

Huntington . . . . . . . . . . . . . . Checkroom Clerk.

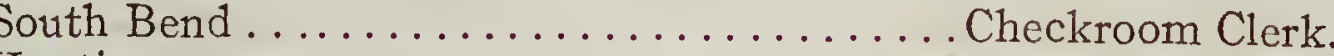

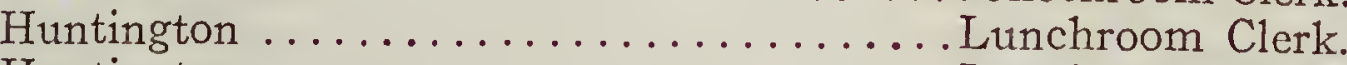

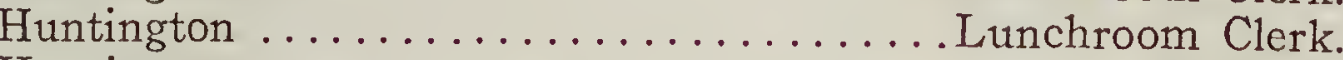

Huntington $\ldots \ldots \ldots \ldots \ldots \ldots \ldots \ldots$ Lunchroom Clerk.

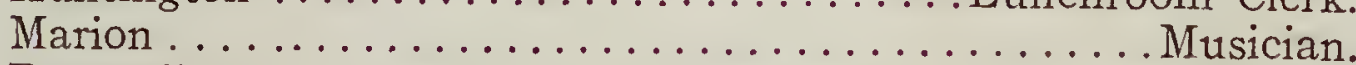

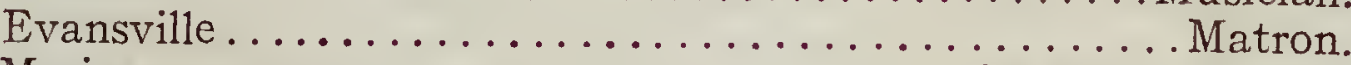

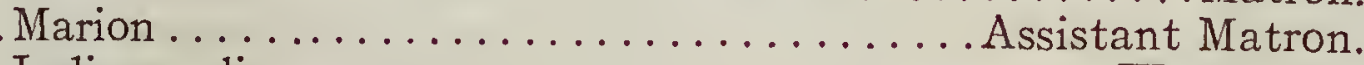

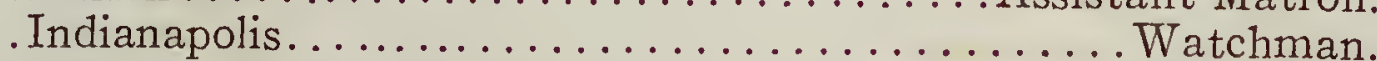

Indianapolis..................... Watchman.

Shelbyville .............................. Watchman.

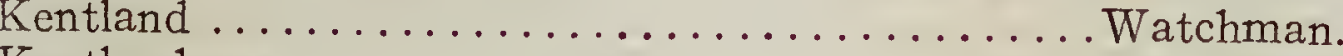

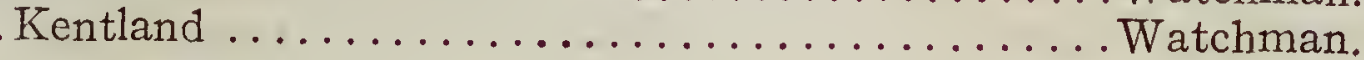


*Wert, Jos.

Kentland

Watchman.

Armstrong, Eugene.

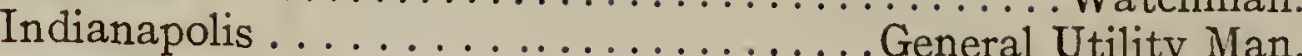

*Walters, Edward

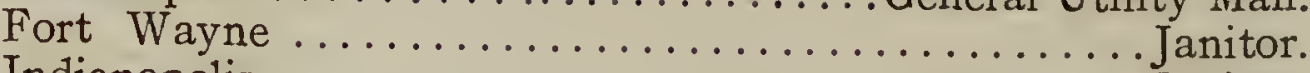

*Goodall, W. T. . . .................. Indianapolis . . . . . . . . . . . . . . . . . . . . Janitor.

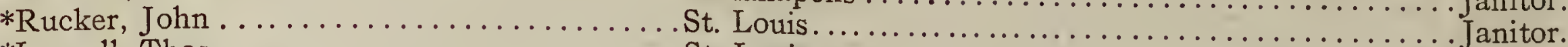

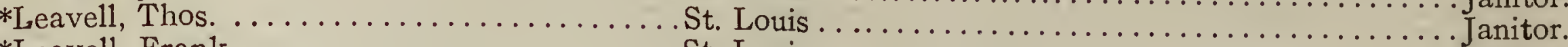

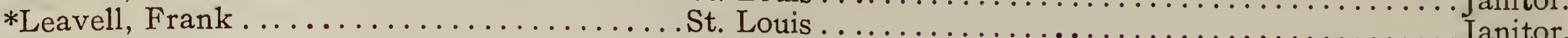

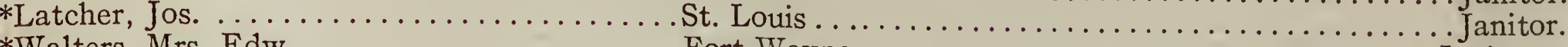

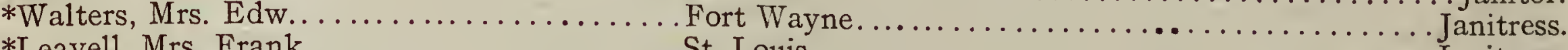

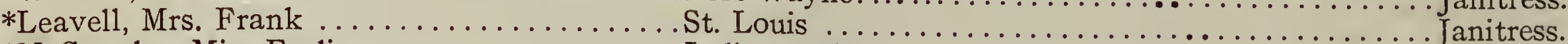

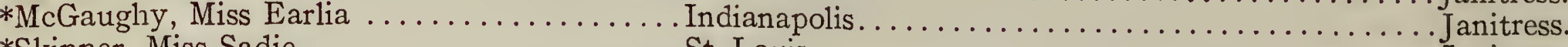

*Skinner, Miss Sadie.................... St. Louis.............................. Janitress.

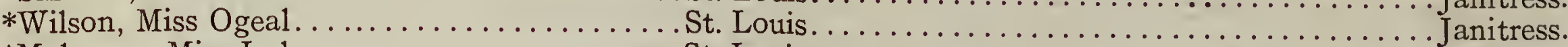

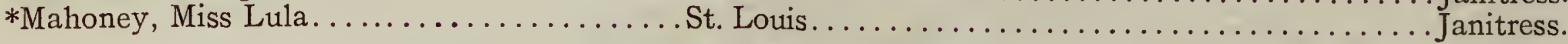

\section{AGRICULTURAL EXHIBIT.}

Name.

Residence.

Employed.

Clore, L. B.

Franklin

Superintendent.

Overstreet, Joseph.

Franklin.

. Superintendent.

Name.

STONE EXHIBIT.

mmons, Thos. W

Residence.

Bloomington

Employed as

COAL EXHIBIT.

Name.

Residence.

Jonesboro

Aployed as

*Hill, Chas.

WOMAN'S WORK EXHIBIT.

Name.

Residence.

Employed as

Berryman, Mrs. W. L

*Ellison, Miss Phoebe.

Tipton.

Fort Wayne

Superintendent.

*Lyman, Miss Louise.

*Foster, Mrs. Myrtle.

Fort Wayne

Attendant.

*Moore, Mrs. Deck .

Fort Wayne

Attendant.

*George, Miss Effie

Kokomo...

Attendant.

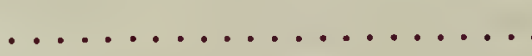

*Homer, Miss Irene

Kokomo.

Attendant

*Jackson, Miss Mary .

Kokomo.

Attendant.

Lafayette.

Attendant.

*Bales, Miss Albarrie.

Lafayette.

Attendant

*Simons, Miss Jennie

Lafayette.

Attendant.

Albion

Attendant

*Parmelee, Miss Helen

Fort Wayne

Attendant.

*Lohman, Miss May .

Indianapolis

Attendant.

*Beuter, Miss Cleopha

Kendallville

Attendant.

*Finch, Miss May

Fort Wayne

Attendant.

Attendant.

Fort Wayne

Attendant. 


\section{EDUCATIONAL EXHIBIT.}

Name.

Residence.

Employed as

Millis, W. A.

Crawfordsville

Superintendent.

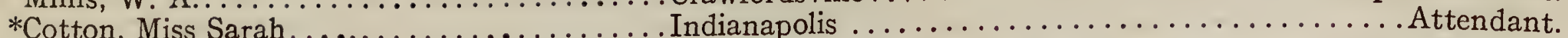

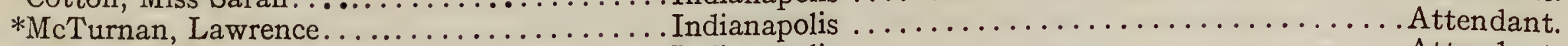

*Hestor, F. D . . . . . . . . . . . . . . . . . . . . . . . Attendant.

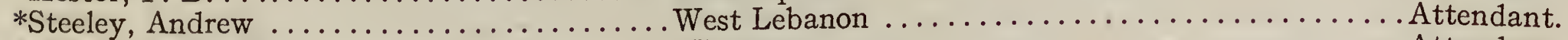

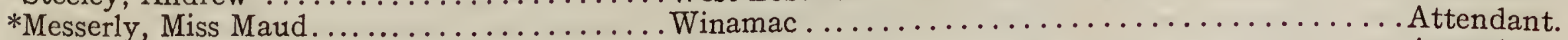

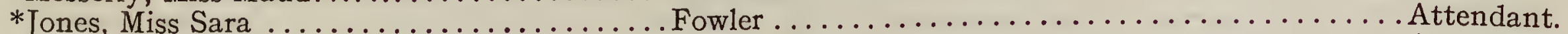

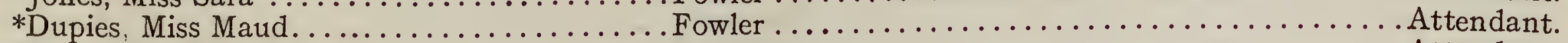

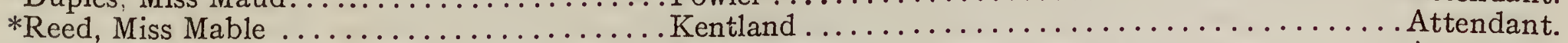

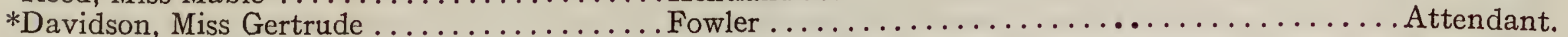

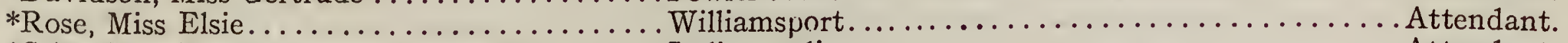

*Crim, Miss Margaret . .................. Indianapolis . . . . . . . . . . . . . . . . . . Attendant.

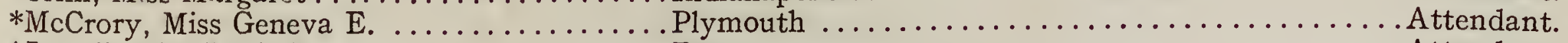

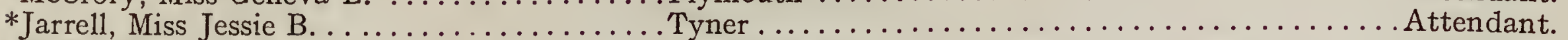

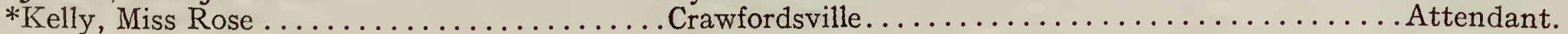

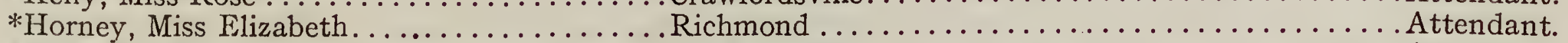

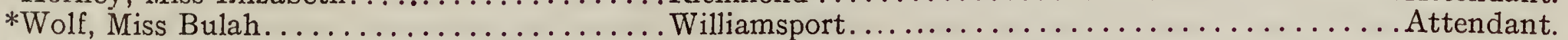

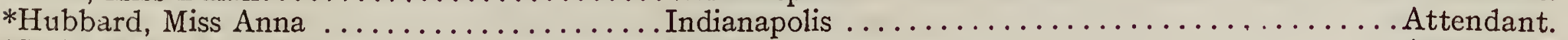

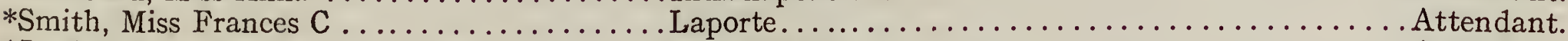

*Jordan, Miss Lina .................... New Castle ............................ Attendant.

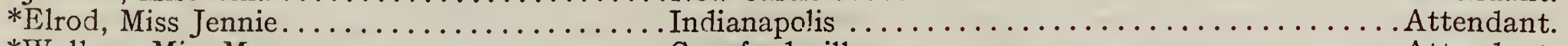

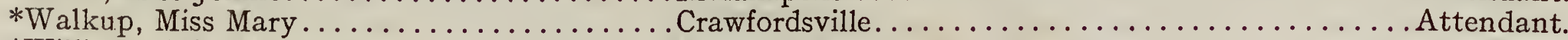

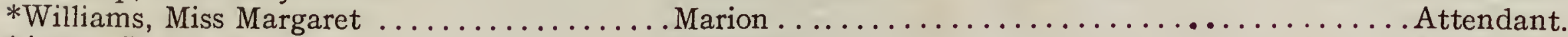

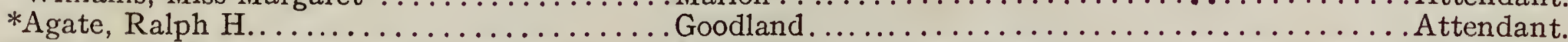

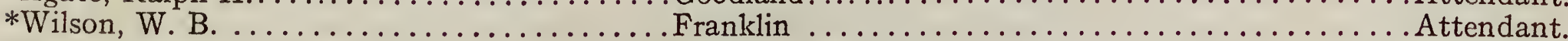

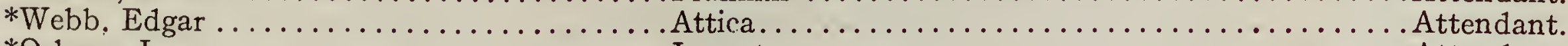

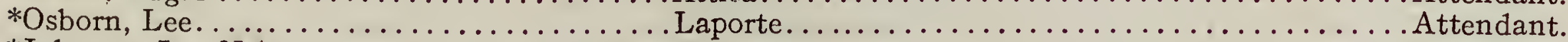

*Johnson, Jos. N. ................... Kokomo............................. Attendant.

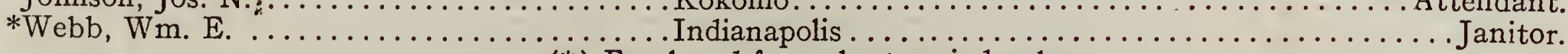

(*) Employed for a short period only.

\section{CULVER MILITARY ACADEMY AND CULVER NAVAL SCHOOL AT THE WORLD'S FAIR.}

The cadets of the Culver Military Academy encamped at the Exposition from May 23 to June 2, 1904. The organization included the battalion of infantry and band, cavalry troop of forty horses, two sections of field artillery with horses, Gatling gun detachment, and cadet company of engineers.

"It was the general comment of those competent to judge that no other cadet corps, barring that of West Point, approached the Culver cadets in bearing, discipline, and precision and thoroughness in drills."-Governor Durbin. "Other cadet organizations besides the Culver boys have made their appearance at Saint Louis since the Exposition opened and gone through similar exercises, but none with the same eclat or dashing effect."-London Graphic, on "Military Exhibits at Saint Louis." 


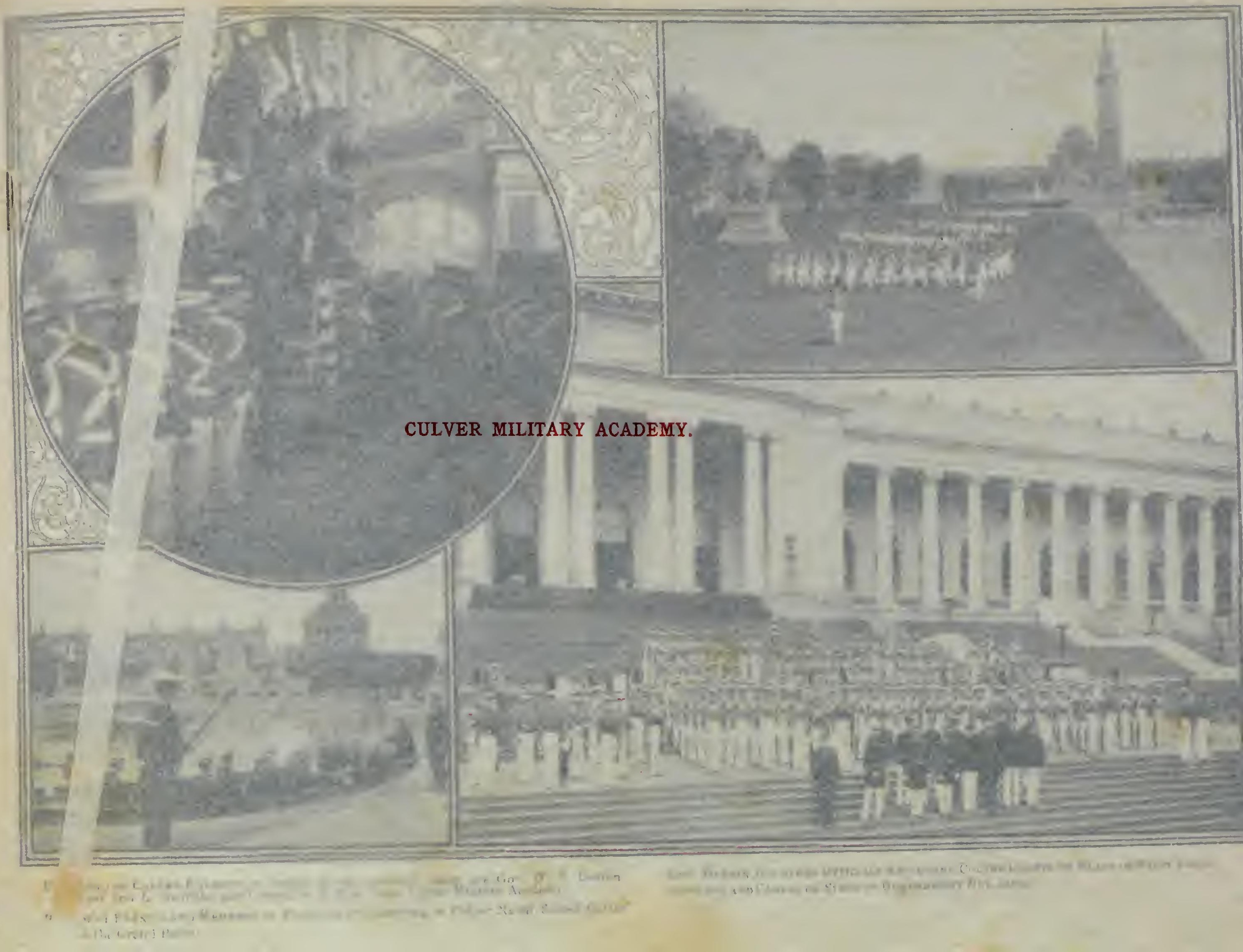




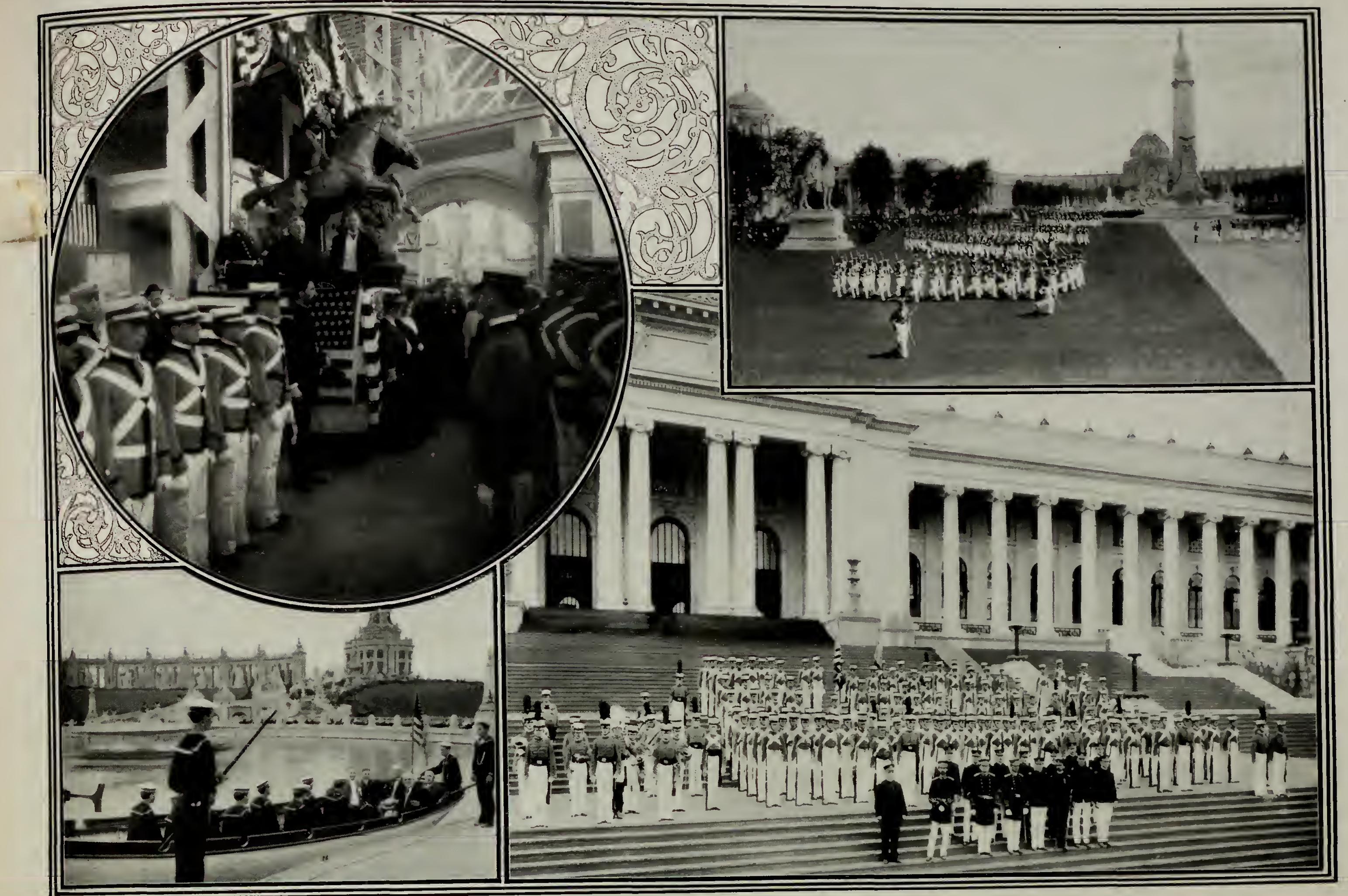

UNEEILING OF CULVER EouESTRIAN GRoup-In the speakers' stand are Gor. W. T. Durbin, Hon Jno. L. Griffiths, and Colonel A. Fineet, Supt. Cuiver Culver Naval Sehool Cutter GOV. DURBIN AND OTHER OFFICIALS REVIEWTAG CULNER CAD PresideNT Grand Basin. 

June 2 was officially designated as "Culver Day." On this date the following program was carried out: In the forenoon cavalry, artillery and infantry drills, and exhibitions of bridge building and wall scaling were given in the Arena of Hale's Fire Fighters. There were present, Governor Durbin, of Indiana, other distinguished visitors, and about 5,000 spectators. In the afternoon there was unveiled at the Palace of Education a bronze equestrian group, executed by Zolnay, representing a Culver cadet standing on three horses, Græco-Roman fashion, in the act hibit, and was awarded a medal. with scenes of cadet life grouped around the pedestal, constituted the Culver exDurbin, Hon. John L. Griffiths, and Colonel A made on this occasion by President Francis, Governor Winfield T. battalion of cadets was reviewed on the Plaza of Saint, Superintendent of the Academy. After the unveiling, the military ball was given in the Hall of Congresses. Souis by the Governor of Indiana. In the evening a grand and other distinguished Indianians, officials of the Seven hundred guests were present, including the Governor the marine ${ }_{3}$ corps.

The cadets of the Culver Summer Naval School also visited the Exposition, and were encamped on the West Point camp site from August 12 to 20. They transferred to Saint Louis four man-of-war cutters, and gave there the only series of naval drills ever given on an exposition lagoon, and attracted much attention.

On the afternoon of August 19 President Francis and the entire executive committee of the Exposition, went aboard the cutters and officially reviewed the work of the cadets. A salute of seventeen guns was fired for President Francis by the cadet gun crews, which was followed by a drill in getting up masts, work under oars, boat races, etc. President Francis highly complimented the cadets on their drill.

A ball was given the cadets in the Indiana State Building on the evening of August 19, and was said to be one of the most attractive social functions given on the Terrace of States.

\section{INDIANAPOLIS NEWS NEWSBOYS' BAND.}

A very pleasant occasion was the coming of the Indianapolis News Newsboys' Band. They came by invitation of the World's Fair officials to take part on Indiana Day. There were fifty pieces and they were under the direction of Prof. J. B. Vandaworker. The Indianapolis News paid all expenses of the trip in way of acknowledgment of the faithfulness of the boys.

It was the night of August 31, that this party left Indianapolis in two Pullman sleepers, arriving at the World's Fair, September 1. They were assigned the best quarters at the Inside Inn and, before entering that famous hostelry, lined up in front and played, "There'll be a hot time in the old town tonight." The boys were loudly applauded by the guests of the hotel. They were assigned a place in the Indiana Day parade and in the afternoon gave a concert on the veranda of the Indiana Building, attended by a throng of admiring Hoosiers.

This boys' band attracted so much attention that the Minneapolis Journal Newsboys' Band challenged them 
for a contest; the challenge was taken and the contest was arranged to take place on the Plaza Saint Louis, September 2, where the two bands met in battle for supremacy. Each band played four selections in the presence of thousands of visitors. The judges were: A. Williams, (Conductor Grenadier Guards Band, London); Wm. Weil, (Conductor Weil's Band, St. Louis); Emil Mollenhauer, (Conductor Boston Band, Boston). The first prize was awarded the Indianapolis News Newsboys' Band without discussion.

John H. McGibbons, Secretary of Awards, in making the awards filed a detailed report. It was highly complimentary to the Indianapolis boys, and their three days' trip to the World's Fair will be a bright spot in their memories as long as they live.

Mr. Frank G. Hay had charge of the party and to him great credit is due. There could have been no better managed affair.

\section{PACKARD BAND, FORT WAYNE, INDIANA}

The Packard Band (Fort Wayne City Band), which organization had the honor of escorting the Governor and his staff in the Indiana Day parade, as well as furnishing concert programs in the afternoon, and at the reception at the Indiana State Building in the evening, is one of the largest and best known musical organizations in the west. To it was accorded the same honor on the similar celebration at the Columbian Exposition in 1893.

Its part in the celebration of Indiana Day consisted in escorting the Governor and his staff in the parade through the grounds to the Indiana State Building in the morning, and in rendering a concert program in the afternoon, and another in the evening at the reception.

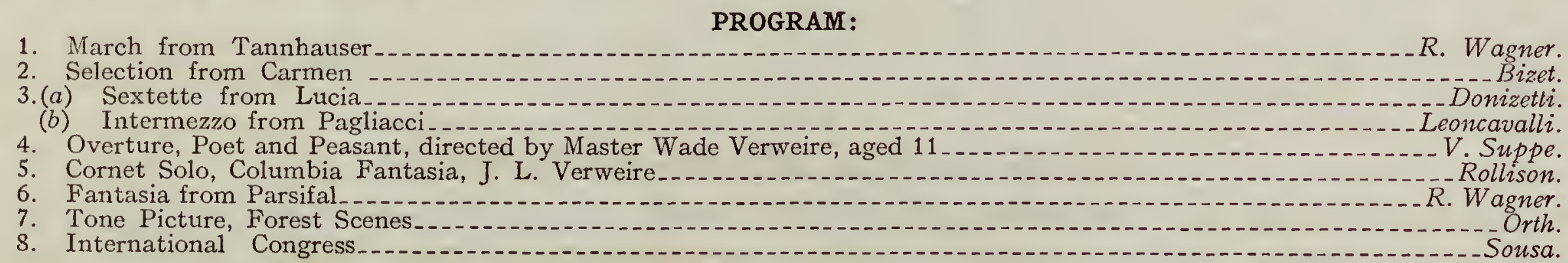

The band is composed of forty-two musicians, under the direction of Bandmaster J. L. Verweire, a student and graduate of the National Conservatory of Belgian, at Ghent, and a man of wonderful power over his musical forces. His ability to please the public was demonstrated on this occasion, as at various numbers of the program great applause was evoked, and gradually the crowd grew, making the event a memorable one. When the final number was reached, portraying the music of many nations, each melody seemed to find response in the heart of some countryman, showing that tribute to the State of Indiana was being paid by many nationalities; and when as a climax "The Star Spangled Banner" was played, the enthusiasm knew no bounds.

The Packard Band was organized in 1871 and was incorporated in 1879, and has the distinction of being the 
oldest similar musical organization of the kind in the state, having been in continuous existence since that time without change of management. Fred. J. Reineke has been at the head of its business affairs since the inception; and its meritorious work through all these years and wide reputation gained thereby, entitled it to represent the State on this occasion.

\section{ANDERSON BOYS' BAND}

The forty-two members of the Anderson Boys' Military Band who attended the St. Louis World's Fair, left Anderson on September - and will retain through life the fondest memories of that trip. No crowd of boys ever had a fuller week's enjoyment, and it is possible that of all the bands at the great Exposition, none attracted more attention.

The trip was projected by the Anderson Morning Herald. Something like $\$ 700$ was raised by the public spirited people of Anderson to defray the expenses of the trip. With this money in hand, the courtesies of railroads, of the Fair management and of the Fair concessionaires, permitted the boys to go to St. Louis in splendid style, to live at good hotels, to see everything and to have ample pocket money for the entire week's outing.

On entering the grounds the first day, the band was photographed in front of the Administration Building. From there they went direct to the Indiana Building, where they found a most enthusiastic welcome. From that time to the end of their visit they made their headquarters at the Indiana Building, and received many courtesies from those in charge. The instruments were stored there, the lunches were eaten there and at most any time a half dozen of the lads in their rough rider or white dress uniforms, could be seen lounging about waiting rooms of the beautiful building, resting from weariness through very enjoyable sight seeing tours. The band was under the management of its very talented leader, Prof. $\mathrm{H}$. Neely, and the party was under the personal direction of E. C. Toner of the Anderson Herald, and it was through Mr. Toner's efforts that from the beginning of the week to the end, the boys had the freedom of the Fair. They played and serenaded everywhere, were addressed by governors of states and other functionaries, and either on the Plaza de St. Louis or on the Pike, they attracted attention. On Missouri Day the band was given a prominent place in the parade.

It was the greatest week the boys of this interesting organization ever had. With all of them the memory of it will last forever, and the especially delightful features of this memory are the manifold courtesies that were everywhere extended the lads in uniform and with instruments.

\section{EXCURSIONS APPRECIATED BY MANY}

Many Indiana people who would not have found it possible to visit the Louisiana Purchase Exposition otherwise, were enabled to do so by means of a series of personally conducted World's Fair excursions run by the Indianapolis Morning Star.

That such a plan would be of great advantage to many residents of Indiana was suggested through constant 
inquiries received by The Star from persons who were anxious to visit the Exposition at St. Louis but who were of necessity seeking an economical means of taking the trip. The matter was presented to the railroads and the result was that The Star was enabled to offer a five days' trip to the World's Fair, including car fare, and lodging and meals at the Cottage City, for $\$ 11.50$.

Nothing so clearly demonstrates the fact that the plan was appreciated as the statistical report at the end of the season showing that more than 3,000 persons took advantage of these excursions. Everything was done for the convenience of the excursionists that was possible and many kindly letters were received by The Star from those who took the trip, many of the writers explaining that they would not have found it possible to visit the Exposition except for this plan.

The excursions ran each Tuesday and were in the personal charge of Mr. E. E. Lowe, an experienced railroad man and excursion manager. The trips wererun alternately over the Big Four, the Pennsylvania and the C. H. \& D. railroad systems.

\section{Official Commendations}

As evidence that Indiana's representation at the Exposition attracted the favorable attention, not only of the visitors from this state, but of those whose official connection with the general management of the Exposition was such as to render them competent and disinterested witnesses, the following official documents, lettersfrom Fair officials to the Commission, selected from among many communications of similar character, are presented:

\section{From President David R. Francis}

"It has been my pleasant privilege on more than one occasion, I believe, to refer in public utterances to the very crevitable showing which Indiana made at the Fair. Of course we expected a fine display from a state possessing the great natural resources and inhabited by a people of the well known culture and thrift of Indiana, and we were not disappointed. By means of the liberal appropriation placed in the hands of a Commission of representative citizens, Indiana was enabled to erect upon the Exposition grounds a beautiful state building and to make superior displays in the departments of Agriculture, Horticulture, Mines and Metallurgy, and Manufactures. The special corn exhibit was characterized by many new features and attracted much attention. The exhibits of needlework and decorated china in the Department of Manufactures were favorably commented upon by the many thousands of visitors who saw them; while Indiana's exhibit of building stone in the Palace of Mines, I am informed by the Chief of that Department, was the finest ever seen by him at any Exposition.

"It is the sincere hope of the Exposition management that the results of Indiana's participation may not only be marked by increased commercial prosperity, but by a closer and still more friendly relationship between the people of your state and those of Missouri and this entire Trans-Mississippi section.

"I wish also to avail myself of this opportunity of thanking the Indiana State Commission and each individual member thereof for the very cordial support and earnest co-operation that the Exposition management 
has received at their hands toward making the Universal Exposition of 1904 a marker of progress in the civilization of the world."

\section{FROM HON. WALTER B. STEVENS, Secretary of the World's Fair.}

"Indiana is represented by one of the most attractive state buildings, which has been the center of some of the most notable social and ceremonial functions during the World's Fair period. In the material sense, Indiana has done herself great credit by her exhibits of horticulture, of dairy, of corn, of agriculture generally, of needle and lace work, of decorated china, of coal, of stone; and her educational exhibits have illustrated the high standard of her school system and of her higher institutions of learning.

"The literature by Indiana authors, the paintings by. Indiana artists, the drawings and manuscripts and art work have shown the state entitled to a place in the front rank of the commonwealths of the country."

\section{FROM MILAN H. HULBERT, Chief of Manufacturers.}

"I wish to take this opportunity to congratulate your Commission upon the attractive exhibit you have made in this department of the needlework and decorated china executed by the women of your state.

"Favorable comments upon both of the exhibits have reached me many times since the opening of the Exposition, and I cannot allow this Exposition to come nearer to its close without advising you that I personally appreciate your successful efforts."

\section{FROM J. A. HOLMES, Chief of Mines and Metallurgy.}

"The Indiana exhibit of building stone here in the Mines Building is the finest I have seen at any Exposition and your Commission deserves great credit for the taste which they have shown in getting up and installing this exhibit. Your coal exhibit is also one of the largest I have seen."

\section{FROM F. W. TAYLOR, Chief of Department of Agriculture.}

"I beg to say that the Indiana exhibits in the Department of Agriculture and Horticulture are above the average of the states. To be more explicit; the general agriculture display is orderly, well grouped and artistically installed, and must reflect credit upon the state and praise to the Commission.

"The special corn exhibit, in which you participate with conspicuous credit, is one of the new features in this latest and largest of expositions. The work of your state in presenting its corn is most excellent. The varieties and the purposes for which the corn has been bred, are fully set forth, and together it makes one of the most pleasing presentations of a subject by any of the states. It is also imposing and pleasing in its physical aspects."

\section{FROM HOWARD J. ROGERS, Chief of Department of Education.}

"In the Department of Education, the State of Indiana received an allotment of space comprising an area of 1666 square feet. In this space there was exhibited the work of the public schools of the cities, counties and rural districts of Indiana, also a general exhibit of the colleges and universities of Indiana and the public library system of the State. 
"The installment of the Indiana Educational Exhibit, comprising an area of 1666 square feet in the northwest corner of the corridor of states in the Educational Building, was one of the most artistic and most admired installations in the Educational Department. The exposition of the school work of the state was most thorough, and its rank, as compared with the other school exhibits of the various states, may be best judged from the fact that the exhibit received one grand prize, seven gold medals, four silver medals, and three bronze medals from the International Jury of Awards.

"I wish to express my very high appreciation of the great interest manifested and the hearty support given by the members of the Indiana State Commission to the Department of Education in the preparation of its exhibit. In our endeavor to place before the people of the world a thorough exposition of the resources of the United States, we had no more active co-operation or more satisfactory contributions than from the schools and colleges of the State of Indiana.

"In addition to the space occupied by the public schools of the state, there was granted a space of 560 square feet to Purdue University in the section of polytechnic schools. The exhibit made by this institution was thorough and comprehensive and was so highly appreciated by the International Jury of Awards as to receive a Grand Prize.

"In the Department of Social Economy, comprising Charities and Corrections, Hygiene, Municipal Improvement, Labor and Industrial Bureaus, etc., Indiana took a very prominent position, and the exhibits, particularly of the Juvenile Court of Marion County, the State Board of Charities and Corrections, and the State Bureau of Labor, were very complete and satisfactory.

"In the Department of Hygiene, no greater commendation can be given the State of Indiana than to state that the entire section was placed in the hands of Dr. J. N. Hurty, Secretary of the State Board of Health of Indiana, and the collective exhibit of Hygiene for the United States and for the worid was prepared to our great satisfaction under his superintendency. His assistant was Dr. Severance of Purdue University, who was in direct charge of the working laboratory of hygiene during the Exposition period.

"The exhibit of the Indiana State Board of Health was of course an important feature in the section of Hygiene."

\section{FROM CHARLES F. MILLS, Chief of Department of Live Stock.}

"The exhibit made by Indiana breeders at the Universal Exposition held at St. Louis the past year, was highly creditable to the state and the very worthy class of your citizens who have made the commonwealth famous for. the excellence of its herds and flocks.

"On the illustrious list of the names of exhibitors of livestock receiving the highest honors at" the" World's Fair, the breeders of Indiana are as usual on the front line and only two states or nations make a better showing for the most coveted prize of the show, than this state. Indiana received more Premier Champion awards on cattle than any other state or nation, and this, the most distinguished honor of the Universal Exposition, was most worthily bestowed upon men who have long honored the state and their profession.

"The display of horses, cattle, sheep and swine made at the World's Fair by the stockmen of Indiana, confirm the skill of our breeders and the enterprise of our citizens who made an exhibit seldom equaled in number and quality by the promoters of the livestock industry, residing in any state." 


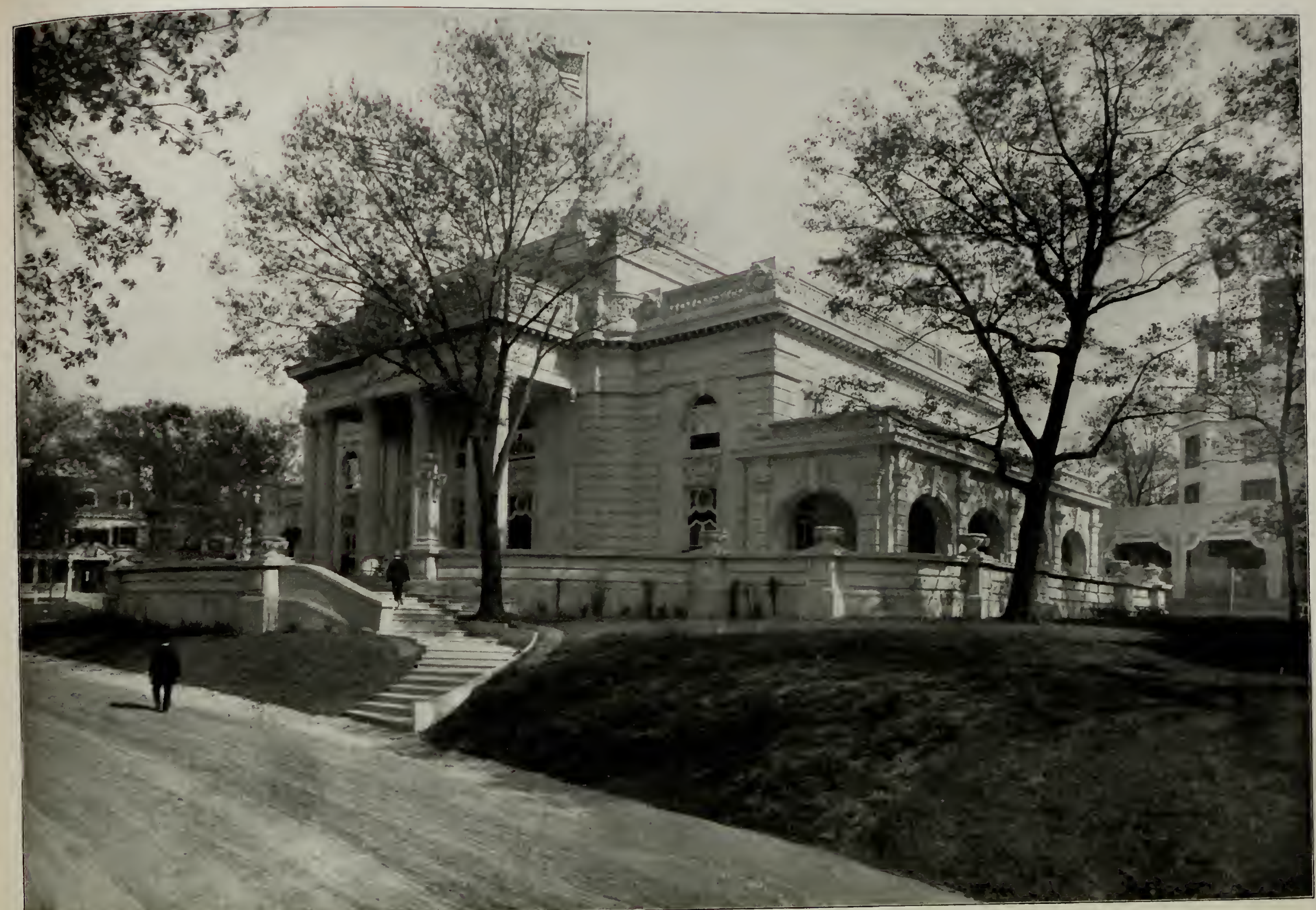




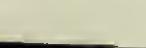




\section{Joint Resolution Passed by the 64th General Assembly}

Whereas, The Indiana Exposition Commission, charged with the responsibility under an act of the Sixtythird General Assembly, for providing proper representation of the state's interests at the Louisiana Purchase Exposition, has about concluded its official labors by submitting a report of its proceedings to the Governor of the state, and

Whereas, Through the faithful and intelligent service of this Commission, the State of Indiana achieved a place at the greatest of international expositions second to that of no other state in respect to the beauty and hospitality of her building, the number of her citizens in attendance, the character of her public and private exhibits, and the quantity and varieties of awards for excellence, and

WhEREAS, These notable results have been achieved by a Commission serving without any inducement other than a desire to promote the interests of their state and gain added glory for the name of Indiana, and the members of this Commission have given to their patriotic service such zealous care that among all states represented at the Exposition, Indiana secured a maximum of results at a minimum of expenditure, so that a considerable portion of the appropriation made by the last General Assembly will revert to the State Treasury, and

Whereas, The members of this General Assembly feel that it is as much a public service to commend faithful and successful doing of public duty, as to condemn the failure to perform it: Therefore,

Be it Resolved, by the Senate, the House of Representatives concurring, that the thanks and congratulations of the General Assembly be and hereby are extended to the Indiana Exposition Commission, and to the Hon. A. C. Alexander, Assistant Secretary of the Commission, for the zeal and efficiency with which they have performed their important duties.

\section{Extract From Gov. Durbin's Message to the Legislature}

The commission has performed its duty in a manner calling for special commendation. The representation of the State at the Louisiana Purchase Exposition was such as to reflect great credit ufon the commonwealth. Without lavish expenditure Indiana took high rank among the States and rations represented at St. Louis by reason not only of the beauty of its building and the simple hopitality extended to more than three million persons who crossed its threshold, but because of the character of our private and cfficial exhibits. The Indiana State Building was erected and furnished at a cost of $\$ 60,000$, and was one of the most commodiotis and attractive structures on the Plateau of States. The State collected and installed thirteen general exhibits. on which four hundred and ten awards and prizes were given by the Superior Jury, including nire graind prizes awarded to the State. No other State surpassed this record. Two hundred and twenty-five school corporations and eighty-four counties were represented in the very - creditable educational exhibit made by Indiana, which was by general consent accorded first rank and was awarded 
a gold medal. Thirty-seven counties were represented in the very creditable agricultural exhibit and the same"number in the horticultural exhibit.

The State was represented by one hundred and eight individual exhibitors in addition to those who contributed to the State exhibits. Seventy-seven awards and prizes were given by the Superior Jury to these individual exhibits. A classified list shows thirty-two exhibitors in the Live Stock Department, thirteen in the Department of Liberal Arts, eight in the Department of Manufactures, eight in Machinery Hall, seven in the Palace of Electricity, twelve in the Transportation Building, sixteen in the Department of Agriculture, one in Horticulture. two in the Department of Mines and Metallurgy, two in the Department of Fish and Game, four in the Department of Social Economy, one in Physical Culture and two in the Art Palace. In the live stock exhibit Indiana made a showing exceeded by only two other states or nations. Of premier champion awards on cattle Indiana received more than any other state or nation.

Including those who participated in the state exhibits and the individual exhibitors, there were eight hundred and six of our citizens who in some way exhibited products of the state at the Exposition, at an estimated aggregate value of $\$ 250,000$. In attendance at the Exposition Indiana surpassed every state except Missouri. Indiana has just ground for pride in the prestige attained by the splendid comparative showing made at St. Louis and has reason to feel that the appropriation made for this purpose was an excellent investment. Of the $\$ 150,000$ appropriated the commission will be able to return at least $\$ 15,000$ to the State Treasury.

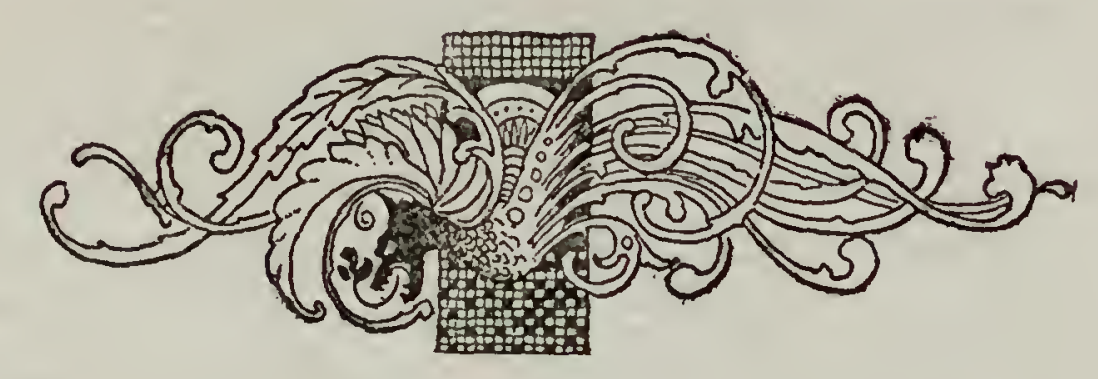




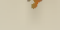




$$
1
$$



